Paulo José de Siqueira Tiné

\title{
Procedimentos Modais na Música Brasileira: Do campo étnico do Nordeste ao popular da década de 1960.
}

Tese apresentada ao Programa de Pós Graduação em Música, Área de Concentração Musicologia, Linha de Pesquisa História, Estilo e Recepção da Escola de Comunicações e Artes da Universidade de São Paulo da Universidade de São Paulo, como exigência parcial para obtenção do título de Doutor em Música, sob orientação do Prof. Dr. Marcos Branda Lacerda. 
Paulo José de Siqueira Tiné

\section{Procedimentos Modais na Música Brasileira:}

Do campo étnico do Nordeste ao popular da década de 1960.

Tese apresentada ao Programa de Pós Graduação em Música, Área de Concentração Musicologia, Linha de Pesquisa História, Estilo e Recepção da Escola de Comunicações e Artes da Universidade de São Paulo da Universidade de São Paulo, como exigência parcial para obtenção do título de Doutor em Música, sob orientação do Prof. Dr. Marcos Branda Lacerda. 
Comissão Julgadora 


\section{RESUMO}

a) Objetivos: Traçar um perfil dos procedimentos melódicos modais presentes nas manifestações étnicas e populares do nordeste brasileiro afim de verificá-los em autores ligados à música popular do Brasil na década de 1960, cotejando os diferentes procedimentos harmônicos realizados.

b) Métodos: O principal método utilizado foi o da análise a partir da transcrição de exemplos em áudio. A partir dessas análises uma série de comparações com materiais similares encontrados na bibliografia foi realizada.

c) Resultados: Como resultado dessa pesquisa foram apontados os principais modos e traços cadenciais utilizados no repertório étnico e popular escolhido do nordeste brasileiro. Esses traços foram importantes na construção das canções aqui selecionadas, características da chamada MPB da década de 1960 apresentando, a partir dessas análises, os principais procedimentos harmônicos desses autores relacionados aos modos e traços cadenciais encontrados.

d) Palavras chave: modalismo, canção de protesto, baião, coco, catimbó, capoeira, candomblé, cantoria, Edu Lobo, Luiz Gonzaga, Jackson do Pandeiro, Milton Nascimento, Baden Powell, música popular brasileira, jazz modal. 


\begin{abstract}
e) Objectives: Delineating a profile of the modal melodic procedures present in the ethnic and popular manifestations of the Northeast region of Brazil in order to verify them in authors connected to the Brazilian popular music from the 1960's, comparing the different harmonic procedures produced.

f) Methods: The main method used was the analysis of transcripts of audio samples. From these analyses a series of comparisons with similar materials found in the bibliography was made.

g) Results: As a result of this research, the main modes and cadential traces used in the ethnic and popular repertoire chosen from the Northeast of Brazil were indicated. These traces were important in the construction of the songs here selected, characteristics of the so-called MPB of the 1960's presenting, from those analyses, the main harmonic procedures of those authors related to the cadential modes and traces found.

h) Key-words: modality, protest song, baião, coco, catimbó, capoeira, candomblé, cantoria, Edu Lobo, Luiz Gonzaga, Jackson do Pandeiro, Milton Nascimento, Baden Powell, Brazilian popular music, modal jazz.
\end{abstract}




\section{Agradecimentos}

Gostaria de agradecer aos meus pais, cujos laços nordestinos nunca foram esquecidos. À minha querida Paola com quem tanto aprendo e aos meus filhos Pedro e Ana.

Às inestimáveis contribuições de meu orientador Marcos Lacerda, e aos doutores da banca de qualificação Rogério Costa e Sidney Molina.

Agradecer aos meus amigos "gauleses”, interlocutores que indiretamente me ajudaram na construção de algumas idéias e, em especial, Celso Cintra, que me apresentou (e me emprestou) diversas obras de Daniélou e Yekta Bey.

Por fim, aos meus alunos e músicos que me acompanham nas Big Bands, Orquestras e Quartetos e a Maricene Crus pelo Abstract. 


\section{SUMÁRIO}

RESUMO

iii

ABSTRACT iv

Apresentação 9

1. Introdução - Questões Terminológicas do Assunto Abordado 10

1.2 Alguns Aspectos Históricos Relacionados à Música Européia e Brasileira $\quad 14$

$\begin{array}{ll}1.3 \text { Aspectos Históricos da Música Popular } & 15\end{array}$

1.4 Compositores escolhidos dentro dos contextos Históricos e Estéticos: 18

Canção de Protesto e Nacionalismo

$\begin{array}{ll}\text { 1.4.1 Edu Lobo e Mário de Andrade } & 18\end{array}$

$\begin{array}{ll}\text { 1.4.2 Música Viva e Popular no Estado Novo } & 19\end{array}$

$\begin{array}{ll}\text { 1.4.3 Referências Nordestinas } & 21\end{array}$

1.4.4 Congresso de Praga e o Teatro de Arena $\quad 21$

1.4.5 Música Nova e Canção de Protesto na Década de 1960

$\begin{array}{ll}\text { 1.4.6 Hermeto Pascoal e sua Escola } & 27\end{array}$

1.4.7 Décadas de 1980 e 1990 e a Globalização 28

$\begin{array}{ll}1.5 \text { Objeto de Pesquisa } & 28\end{array}$

2. Revisão dos Parâmetros Analíticos 30

2.1 Procedimentos Analíticos Adotados $\quad 34$

2.2 Sistemas e Processos Modais 36

2.2.1 A Concepção de Modo no Contexto Medieval e Fora do Ocidente 37

2.2.2 A Concepção de Modo Medieval e Renascentista 42

2.2.3 A Concepção de Modo no Romantismo Tardio 44

2.2.4 A Concepção de Modo no Âmbito Étnico-Popular Brasileiro 44

2.2.5 A Concepção de Modo no Século XX 45

2.2.6 O Modalismo no Jazz $\quad 48$

2.3 A Harmonia e o Improviso no Jazz Modal 50

3. Busca dos Fundamentos Étnico-Musicais do Repertório Modal da Música

$\begin{array}{ll}\text { Popular } & 54\end{array}$

3.1. Candomblé $\quad 55$

3.1.1 Canto para Ossaim $\quad 55$

$\begin{array}{ll}\text { 3.1.2 Canto para Xangô } & 58\end{array}$

3.1.3 Canto para Yemanjá $\quad 60$

3.2. Capoeira $\quad 62$

3.2.1 Tava Lá em Casa $\quad 62$

$\begin{array}{ll}3.2 .2 \text { Pisa Caboclo } & 63\end{array}$

$\begin{array}{ll}\text { 3.3. Coco } & 64 \\ 3.3 .1 & 640 v o \text { Quilombo Chegou }\end{array}$

3.3.1 Novo Quilombo Chegou 64

3.3.2 De que Lado eu Remo $\quad 65$

$\begin{array}{ll}\text { 3.3.3 Estrela D'alva } & 65\end{array}$

3.3.4 Vai, vai, vai, ô mulher $\quad 66$

3.3.5 Eu Vou, Marido eu Vou 66

3.3.6 Ô Mulher, Você foi Embora 67 
3.3.7 No Rio Chegou um Peixe $\quad 67$

3.3.8 Saudação 68

3.3.9 Usina Grande 68

3.3.10 Sem Título $\quad 69$

3.3.11 Eu Pisei na Ponte $\quad 69$

$\begin{array}{ll}3.4 \text { Catimbó } & 71\end{array}$

$\begin{array}{ll}\text { 3.4.1 Mestre Manuel Cadete } & 71\end{array}$

3.4.2 Mestre José Fulo da Noite ou Mestre Adivinhão 72

3.4.3 Mestre Dom João do Outro Mundo $\quad 72$

3.4.4 Mestre Menino $\quad 73$

3.4.5 Mestre Laurinda ou Mestre Lauriano $\quad 73$

$\begin{array}{ll}\text { 3.4.6 Mestre Caboclo Daniel } & 74\end{array}$

3.4.7 Mestre Belarmina ou Mestre Belarmino 74

3.4.8 Mestre do Envultamento $\quad 75$

$\begin{array}{ll}\text { 3.5.1 Cantoria } & 76\end{array}$

3.5.1 Cantoria/Os Sacrifícios de São Cícero Romão 76

3.5.2 Promessa ao Padre Cícero 77

$\begin{array}{ll}3.5 .3 \text { Sextilhas } & 77\end{array}$

3.5.4 Oito Pés à Quadrão/ Dez Pés à Quadrão 78

3.5.5 Vida, Sofrimento e Glória do Padre Cícero Romão 79

3.5.6 Eu também sou Cangaceiro/ Minha Arma é a Viola 80

3.5.7 Lampião fez muita gente/ Abandonar o Sertão 80

3.6 Considerações Parciais $\quad 81$

4. Luiz Gonzaga e Jackson do Pandeiro: Os Mensageiros do Norte 88

4.1 Juazeiro (Luiz Gonzaga e Humberto Teixeira) 89

4.2 Baião (Luiz Gonzaga e Humberto Teixeira) 92

4.3 Vem, Morena (Luiz Gonzaga e José Dantas) 96

4.417 na Corrente (Edgard Ferreira e Manoel F. Alves) 99

4.5 O Canto da Ema (João do Vale, A. Cavalcanti e Ayres Viana) 103

4.6 Considerações Parciais 106

5. Algumas Utilizações do Modalismo no Repertório Selecionado da Música Popular do Brasil da década de $1960 \quad 109$

5.1.1 Baden Powell/Consolação (Baden Powell e Vinícius de Moraes) 109

5.1.2 Berimbau (Baden Powell e Vinícius de Moraes) 113

5.1.3 Canto de Ossanha (Baden Powell e Vinícius de Moraes) 116

5.2.1 Edu Lobo/Arrastão (Edu Lobo e Vinicius de Moraes) 121

5.2.2 Chegança (Edu Lobo e Oduvaldo Viana) 126

$\begin{array}{ll}\text { 5.2.3 Borandá (Edu Lobo) } & 130\end{array}$

5.3.1 Morro Velho (Milton Nascimento) 133

5.3.2 Vera Cruz (Milton Nascimento e Márcio Borges) 139

5.3.3 Canção do Sal (Milton Nascimento) 141

5.4 Considerações Parciais 144

6. Conclusão 148

6.1 Cotejamento dos Dados 148

6.1.1 Aproveitamento do Gênero Pentatônico 148

6.1.2 Aproveitamento do Gênero Diatônico Puro: $5^{\circ}$ Modo 151

6.1.3 Aproveitamento do Gênero Diatônico Puro: $6^{\circ}$ Modo 152

6.1.4 Aproveitamento do Gênero Diatônico Puro: $4^{\circ}$ Modo 152

6.1.5 Aproveitamento do Gênero Diatônico Puro: $2^{\circ}$ Modo 153

6.2 Uso do IIb: Despontar do Frígio 155 
6.3 Procedimentos Harmônicos Ligados ao Modalismo 156

6.4 Relação entre Conteúdo e Material 158

6.5 Construção da Identidade através da Alteridade 159

6.6 Relação Letra e Música 161

6.7 Aspectos Rítmicos relacionados ao Modalismo 162

6.8 A Fraseologia e o Modalismo 164

6.9 Procedimentos Rapsódicos na Construção dos Arranjos e o Papel da Improvisação

7.1 Milton: o Rock e o Folclore 169

7.2 Tropicália 172

7.3 Depoimentos de Edu Lobo 174

7.4 Hermeto Pascoal: Síntese dos Procedimentos 177

REFERÊNCIAS BIBLIOGRÁFICAS 183

$\begin{array}{ll}\text { ANEXOS } & 191\end{array}$ 


\section{Apresentação}

O presente trabalho está dividido em sete capítulos. O primeiro trata de questões históricas e terminológicas introdutórias ao assunto abordado. O segundo enfoca propriamente a questão dos modos, apresentando a nomenclatura analítica adotada ao longo dos diversos corpus musicais e perpassando pelas diferentes concepções de modos relacionados com diferentes épocas, culturas e estilos, bem como sistemas de afinação correspondentes. Nesses dois primeiros capítulos são abordados dois assuntos complexos: o ideário sociológico em torno da questão étnica do repertório e a questão da difinição dos modos. Já o terceiro capítulo aborda analiticamente um corpus étnico musical relacionado ao Nordeste brasileiro, o qual servirá de fundamentação para os repertórios que se seguem. O quarto capítulo é um deles, relacionado aos compositores Luiz Gonzaga e Jackson do Pandeiro. Ao quinto capítulo está reservado o repertório da década de 1960 a partir das canções selecionadas de Baden Powell, Edu Lobo e Milton Nascimento. Ao final dos capítulos III, IV e V há as seções intituladas “Considerações Parciais”. O sexto capítulo procura cruzar os dados levantados naquelas seções, com o objetivo de se extraírem algumas conclusões. A partir destas, o Capítulo VII traça as últimas considerações para além do corpus selecionado e dos períodos históricos abordados. 


\section{Introdução - Questões Terminológicas do Assunto Abordado}

As considerações que se seguem não possuem o intuito de constituir um estudo historiográfico e se fundamentar em teorias da história da música. Entretanto, apresentam uma reflexão sobre diversos assuntos relacionados ao tema principal desta tese.

A maioria dos estudiosos da harmonia clássica ocidental que tiveram por objeto de estudo a harmonia tonal colocou, grosso modo, suas atenções a partir do período da história da música denominado Barroco. Arnold Schoenberg, Hugo Riemann, Henrich Schenker, Dietter de La Motte, para citar alguns, colocam o foco na relação dominante-tônica, e seus respectivos desdobramentos (modulações, digressões, ampliações cadenciais) como o mote evolutivo da harmonia tonal. Obviamente há outros fatores paralelos que contribuíram para tais desdobramentos como, por exemplo, o do temperamento igual e o uso diferenciado da dissonância. Por conseqüência, poder-se-ia imaginar um mapa geográfico de uma "corrente principal” da música ocidental do Barroco ao final do Romantismo: um eixo GermânicoFranco-Itálico, tal como Mário de Andrade se referia ao denominar as "três grandes escolas.”1

Por mais que se enumere uma série de compositores de outras nacionalidades que são importantes nesse período, pode-se constatar que são considerados, salvo algumas exceções, compositores “periféricos” - Dvorak, Grieg, Murssogsky, Albeniz, etc. Por outro lado, é preciso lembrar que o contorno geopolítico da Europa no século XIX era bastante diferente do contorno atual, ainda mais quando se lembra de todas as turbulências ocorridas naquele século em virtude da revolução francesa e seus reflexos nos outros países. E é principalmente naquele "eixo" que a harmonia tonal se desenrola, desde relações mais simples em um Vivaldi até a complexidade de um Wagner, e tais tratadistas citados anteriormente colocaram o foco da teoria harmônica principalmente dentro dessa vertente. ${ }^{2}$ Além disso, durante o século XIX, o papel que cidades como Paris, Viena e Milão, por exemplo, desempenharam foi de extrema importância, e compositores de outras localidades como Chopin, Brahms, Frank, dentre outros, desenvolveram suas carreiras nesses grandes centros.

Por outro lado, é fato que a visão ou leitura de que o modalismo fosse empregado ao nível da harmonia nunca foi bem-aceita por muitos teóricos e músicos.

\footnotetext{
${ }^{1}$ ANDRADE, 1987, p.149.

2 “ While German, French and Italian cultural hegemony attempted to transcend the national basis to achieve universality of thought and style, on the periphery there is a sustained concentration on the research of forms and themes expressive of the 'national character.'” DASILVA, 1979, p.167.
} 
The word 'modality', however, is ambiguous and misleading when used as a term to describe this stage of harmonic evolution, since modal system is a specifically melodic development, never fully or consistently applied to harmony. ${ }^{3}$

Nesse contexto, muitas vezes o músico procura uma terminologia (modalismo), por vezes inadequada, para descrever um fenômeno sonoro que está percebendo e, em contrapartida, às vezes um teórico, em nome de uma acuidade terminológica, pode se esquecer de se implicar na questão, de se perguntar como está percebendo auditivamente o fenômeno. Por outro lado, o músico prático às vezes deixa de lançar mão de terminologias corretas, quando não acessa a informação teórica e termina se confundindo e confundindo outros músicos ao seu redor.

Apesar de tais controvérsias sobre a existência ou não de uma "harmonia modal” (e outras que serão descritas a seguir), existem outros teóricos como Walter Piston e Joaquin Zamacois, por exemplo, que aceitam a hipótese de um "modalismo" transposto ao nível da harmonia. Este poderia, basicamente, ser pensado aqui como uma polarização de um grau num campo harmônico que se daria sem o artifício do acorde de $7^{\text {a }}$ dominante: uma polarização diatônico-harmônica não tonal. Logo, uma segunda controvérsia advém: para alguns como Elliot Antokoletz, ${ }^{4}$ é incorreta a aplicação do termo diatônico para formações escalares que não sejam pertencentes ao campo dos modos gregorianos, e a palavra polarização, por outro lado, traz conotações advindas das teorias de Edmund Costère. Para este autor, entretanto, o “estilo modal”, como o denomina, dá-se pela negação da tendência tonal (atração cardinal) que também baliza sua teoria. ${ }^{5}$

Este elemento, o do "estilo modal”, foi mais característico dos tais compositores periféricos ao “eixo” colocado, principalmente aqueles pertencentes ao que Otto Maria Carpeuax (1967) chamou de segunda onda nacionalista na Europa. Por terem buscado originalidade na música folclórica de seus respectivos países, encontraram-na em elementos arcaicos (maneirismos modais) que sobreviveram em comunidades mais afastadas do desenvolvimento musical das sociedades capitalistas européias. Ao harmonizar melodias folclóricas modais, parece ser natural que se busque realizar as mesmas "polarizações”

\footnotetext{
${ }^{3}$ RUE, Jan la. Guidelines For Style Analysis. New York-London: W.W. Norton \& Company, 1970. p 52.

${ }^{4}$ ANTOKOLETZ, Elliot. The Music of Bela Bartók: A Study of Tonality and Progression in Twentieth-Century Music. Berkeley, Los Angeles, London: University of California Press, 1984.

${ }^{5}$ Ver RAMIRES, Marisa. A Teoria de Costère. São Paulo: Embraform Formulários, 2001.
} 
encontradas nas melodias no plano harmônico. “ "Era hábito a harmonização de canções populares no século XIX; tratava-se, possivelmente, de reconstruir e transformar atmosferas - pode-se dizer exóticas - por meio do inflexível temperamento do piano.”7

É interessante notar que, mesmo quando se encontram esses traços em compositores germânicos como Brahms, ou até posteriormente no Impressionismo francês de um Maurice Ravel, estes parecem ter buscado tais traços de um passado remoto pertencente à própria tradição musical histórica proveniente de períodos pré-tonais, como no Quarteto de Cordas em Fá Maior ou, ainda, buscando inspiração em povos periféricos alheios, como nas Danças Húngaras. ${ }^{8}$ Nesse caso, pode-se conferir a caracterização estereotipada, por exemplo, dos espanhóis, como em “Carmem”, de Bizet, ou no "Capricho Espanhol”, de Korsakov. É de supor que tal fenômeno corresponderia, no contexto do século XIX, ao nacionalismo temático e literário de José de Alencar e Carlos Gomes. ${ }^{9}$

Ainda que se admita o erro e a falta de acuidade terminológica na questão desses modalismos e suas implicações, cabe a questão: mesmo que tal elemento se dê como "um modalismo que funciona como um sabor modal dentro do sistema tonal”, como ele se dá?

É na transposição de planos, como a do plano melódico para o harmônico ou de diferentes períodos da História da Música, que muitos termos se tornam problemáticos. Termos como "cadência” e “dominante” passaram do plano melódico do cantochão para o plano das cadências harmônicas, e a acepção da nota dominante passou das notas recitadas ou tenor, ou seja, das fórmulas usadas pelos cantores para entoar os salmos, para a função harmônica do acorde de dominante construído no $\mathrm{V}$ grau diatônico da escala maior. ${ }^{10} \mathrm{Na}$ transposição fraseológica pode haver uma coincidência na frase cadencial com a cadência

\footnotetext{
6 “Las escuelas nacionalistas - con el estudio del folklore musical y la incorporación de sus características modales a la música cultivada -, las investigaciones gregorianistas- evidenciando las bellezas y variedad de matices de esa música (...), a ansia de novedad (...), y la mirada retrospectiva (...), han sido los factores más importantes que en la última parte del passado siglo [XIX], (...), han abierto de par en par las puertas de la tonalidad moderna a todos elementos modales que pueden enriquecer nuestro 'major' y 'menor' sin negarlos en lo que constituye su esencia: el acorde de tónica.” (ZAMACOIS, 1994, p.397)

${ }^{7}$ LACERDA, Marcos B. In: FERRAZ, Sílvio (org.). Notas. Atos.Gestos. Rio de Janeiro: 7letras, 2007. p.24.

${ }^{8}$ Ainda que nas Danças Húngaras não sejam encontradas tais “cadências modais”, mas, sim, em alguns Intermezzos.

${ }^{9}$ [...]seu nacionalismo é literário, por ser, acima de tudo, temático. Os diversos tipo regionais que passam na obra de José de Alencar são brasileiros por constituírem uma temática literária, e não por se identificarem como tais. [...] O mesmo pode ser dito em relação a Carlos Gomes e sua música. Não há grande diferença entre o compositor de $O$ Guarani, e o da Fosca ou Salvador Rosa. [...] se dirá que é nacionalista trata da história de um índio [...] O compositor não acede que suas obras devam ser nacionais no sentido radical de ir ao folclore - mas que tem de ser tematicamente nacionalistas. [...] Se o próprio Wagner cede ao exotismo das religiões orientais, por que não concordar que Carlos Gomes fosse, de um certo modo o ingrediente que convinha ao modismo exótico que redundou nas óperas de Bizet, David e de outros? (SQUEFF, 2004, p. 22-23)

${ }^{10}$ Ver Hoppin, Richard H. Medieval Music. New York/ London: w.w.Norton \& Company, 1978. P. 67 e 77.
} 
harmônica, mas, uma expressão como a da cadência plagal padece da mesma transposição de planos.

No campo orientalista há também a impertinência da aplicação do termo “modo” para culturas não-ocidentais. Este é o caso, por exemplo, dos conceitos de makam e raga - dos países árabes e da Índia; são mais abrangentes, ou seja, atribui uma série de significados extramusicais em um âmbito civilizatório, coisa que o Ocidente vai dissociar historicamente e só relacionar significados a níveis individuais, ou seja, de compositor para compositor.

Besides the musical characteristics of ragas there are several extra musical features such as rasa, personification, often deification, pictorial representation, magic properties, and fixed performance times. (KAUFMANN, 1985, p.10.)

Entretanto nota-se que, mesmo o antigo conceito ocidental (modo) não dizia respeito unicamente a uma escala e que, na Grécia Antiga, também exercia funções extramusicais, como se vê descrever Platão na "República”, por exemplo. E a própria significação do termo modo significa “maneira, feição ou forma particular; jeito.”11

It is hardly necessary to point out the resemblance of rasa to the ethos of ancient Greece, or to similar phenomena in the music of the Renaissance and Baroque periods of the West, particularly the Affektenlehre of the late eighteenth century. (Ibid., p.10)

Portanto, caso se considere a hipótese de uma harmonia que se dá modalmente, isso ocorre porque houve um modalismo melódico que o antecedeu historicamente. Cabe perguntar, então, sobre quais definições de sistemas modais, que são inúmeras e historicamente diferenciadas, e sistema tonal esse trabalho se assenta. Ou ainda, seriam o tonalismo e o modalismo sistemas ou processos? Seria a sistematização teórica sempre um $a$ posteriori a uma praxis ou, em alguns casos de ação conjunta, até mesmo anterior à prática? E, por último, deveria este trabalho correr o risco de partir de algumas acepções do senso comum - modalismo, tonalismo - a fim de buscar redefinições não a partir apenas da reconstituição histórica de todos esses termos, mas, sobretudo, de uma busca através da análise que se assenta, principalmente, na implicação da escuta?

\footnotetext{
${ }^{11}$ Novo Dicionário Aurélio da Língua Portuguesa. Rio de Janeiro: Ed. Nova Fronteira, 1.Ed., s/d.
} 


\subsection{Alguns Aspectos Históricos Relacionados à Música Européia e Brasileira}

O autor Otto Maria Carpeaux, em sua obra Uma Nova História da Música (1967), aponta o compositor alemão Robert Schumann entre os formadores do espírito nacionalista romântico europeu.

Direta ou indiretamente, a influência de Schumann foi maior no estrangeiro do que na Alemanha. Suas ingênuas veleidades de exotismo - lieds escoceses e espanhóis, melodias orientais, etc. - inspiraram inesperado interesse aos numerosos estudantes estrangeiros de música nos conservatórios da Alemanha. (CARPEAUX, 1967, p.182)

Segundo o mesmo autor, este fundamento corresponde ao de uma segunda leva nacionalista na Europa, ou seja, a uma segunda geração, já que a primeira teve como principal expoente o polonês Frederic Chopin e, ao lado de Schumann, o autor coloca o húngaro Franz Liszt como o outro fundador da referida leva. ${ }^{12}$ Lacerda (2007) também aponta alguns procedimentos adotados por Franz Schubert ligados ao aproveitamento de materiais populares e étnicos em sua obra, como o uso da forma canção e harmonizações por terças, práticas correntes da música de salão.

Deve-se lembrar que, segundo Carpeaux, o nacionalismo que viria a caracterizar, sobretudo as tendências do início do século XX nos países latino-americanos, corresponderia a uma quarta onda nacionalista, influenciada pelos procedimentos de Igor Stravinsky e Claude Debussy. Os casos de Bela Bartok e Villa Lobos figuram como um parâmetro dessa tendência, principalmente pelo uso do folclore.

A terceira onda de nacionalismo, sob o signo de Debussy e do
impressionismo, provocou a renascença musical de países que há séculos
estiveram musicalmente silenciosos: Inglaterra e Espanha. A quarta onda de
nacionalismo musical é caracterizada pela influência conjunta de Stravinsky
e Debussy. A música do "bárbaro" russo inspirou aos compositores de
muitas nações coragem para empregar seus 'modos' e melodismos do seu
folclore musical, até então desprezado porque passava por incompatível com
o sistema tonal em vigor [...] (Ibid., p.299-300)

O autor se refere, no caso da terceira onda, a compositores como Edgar Elgar e Manuel de Falla. Mas cabe aqui salientar algumas diferenças em relação aos mesmos

\footnotetext{
12 “Seria exagero atribuir só a repercussão limitada da música de Schumann essa segunda onda de nacionalismo musical. Outra influências contribuíram poderosamente para o mesmo fim: sobretudo a de Liszt.”(Ibid., p.183)
} 
procedimentos no século XIX. É de imaginar que, naquele século, o compositor olhava para a própria cultura ou apenas para culturas européias. Foi com grande esforço que os compositores passaram a olhar para a cultura de etnias estranhas dentro de um mesmo país, além da luta contra o preconceito local. Por isso, não se pode nivelar tal atitude estética no século XX como já “atrasada” em relação aos compositores românticos nacionalistas. ${ }^{13}$ Eles podem ser vistos como fundadores de tal tendência, mas coube ao século $\mathrm{XX}$ ir às últimas conseqüências no uso de procedimentos musicais, primeiramente das classes e etnias menos favorecidas do ponto de vista econômico e cultural e, em segundo lugar, ao uso de procedimentos musicais de culturas não-ocidentais.

\subsection{Aspectos Históricos da Música Popular}

Se "o centro de um mundo é a periferia de outro", pode-se constatar que, se o compositor brasileiro Heitor Villa-Lobos pôde ser visto como pertencente a esta terceira onda nacionalista acima descrita e como compositor periférico no contexto de uma suposta corrente principal da primeira metade do século $\mathrm{XX}$, ele passa a ter um papel polar em relação à música brasileira. Apesar disso, ao escolher melodias folclóricas para pequenas peças pianísticas, o autor escolhe melodias eminentemente tonais ${ }^{14}$, com uma grande extensão e liberdade nas harmonizações. Na obra “A Prole do Bebê No1”15, a utilização de escalas modais parece se dar muito mais ao modo de Debussy, com a "verticalização" livre de tais escalas do que dentro da apropriação de melodias modais populares.

The first, Prole do Bebê [...], was composed in 1918 and stands as a charming and imaginative suite of eight pieces based on traditional children's tunes, which reflects the influence of the impressionist traditions of French music. (DASILVA, 1979, p.170)

O que aqui se chama de "exotismo periférico" - sem nenhuma pretensão de conotação pejorativa - em Villa-Lobos também é obtido com a utilização de ritmos populares, como o samba, por exemplo. Este ritmo, como será apresentado a seguir, colocará também o estado da capital federal do Império e parte do período republicano brasileiro como centro em

\footnotetext{
13 “É esse olhar utópico que ele [Bártok] lança à personalidade de Kodály. Mas, aqui, o que significaria denominar nossos camponeses as culturas indígenas e algumas ramioficações afrobrasileiras? Elas certamente propõem voltar à percepção para outros idiomas e para mais além do que um repertório de puras canções.” (LACERDA, 2007, p. 27-28)

${ }^{14}$ VILLA-LOBOS, Heitor. Cirandinhas. Rio de Janeiro: Ed. Arthur Napoleão Ltda, 1968.

${ }^{15}$ Ibid. Prole do Bebê $N^{o}$ 1. Rio de Janeiro: Ed. Arthur Napoleão Ltda, 1968.
} 
relação aos demais estados e capitais brasileiras. Quando o processo de comercialização do samba se deu através do início da era do rádio e dos meios mecânicos de reprodução como o início da indústria do disco ${ }^{16}$, esse gênero se caracterizou, então, tonalmente do ponto de vista do viés melódico-harmônico. Para isso, é preciso pensar que os primeiros compositores desse gênero não são mais puramente “folclóricos”, ou seja, apesar de fazerem parte de uma comunidade com uma prática musical coletiva baseada na oralidade, eles expandem essa prática para os meios de comunicação e se profissionalizam posteriormente. Compositores como Pixinguinha, Sinhô e Noel Rosa, entre outros, trabalharam, é de supor, no sentido de uma estilização tonal do gênero. Quer dizer, parece ter havido uma neutralização dos elementos modais - como os pentatônicos da cultura afrobrasileira - nessa estilização.

Em relação a esse centro o mundo da música do Nordeste, por exemplo, constituiu uma periferia na qual, além dos ritmos, o exotismo das melodias populares terão grande impacto na constituição de novas identidades, como mostrará o capítulo correspondente.

Notadamente um dos fatores mais preponderantes na constituição de um centro como todos mencionados é o econômico e, por conseqüência, o político. Se isso certamente foi determinante em relação à posição central da cidade do Rio de Janeiro no final do século XIX e início do século XX, certamente a expansão econômica dos Estados Unidos da América colocou esse país na condição de centro político-econômico até os dias de hoje, e gêneros musicais de lá advindos se tornaram centrais, pelo menos no território da música popular, em relação à condição periférica inclusive de países europeus. Gêneros como o jazz e o rock-androll passaram a pautar os gêneros brasileiros em diferentes graus: às vezes somente na instrumentação, outras com a utilização de procedimentos harmônicos, outras numa cópia completa dos gêneros e estilos norte-americanos.

Se a centralidade na música erudita brasileira se situava na Europa, principalmente no referido eixo, a música popular terá nos Estados Unidos da América a sua alteridade que será ora negada, ora afirmada, total ou parcialmente. Assim, os procedimentos adotados, primeiramente no jazz e, a partir da década de 1960, no rock, serão importantes na verificação de sua utilização na música popular aqui focada, principalmente na referida década e, entre eles, o próprio modalismo e o recurso da improvisação.

Na história do jazz, os modos passaram a ser utilizados como ferramentas para improvisação e, por conseqüência, isso ampliou sua aplicação, ainda que tal processo não se diferencie muito da improvisação em outras culturas e que esses modos não sejam

\footnotetext{
${ }^{16}$ Ver VIANNA, Hermano. O Mistério do Samba. Rio de Janeiro: Jorge Zahar Editores, UFRJ, 1995.
} 
propriamente novidades na música ocidental, já que o impressionismo e o nacionalismo, como citados, fizeram largo uso de alguns deles. Um dos fatores que se pretende diferenciar aqui é que, quando esse procedimento se dá em um tema de jazz tonal, ele não muda sua natureza, seja ela tonal ou modal. Portanto, a acepção de tonalismo aqui adotada é larga, ou seja, considerada principalmente a partir do mote V-I e cadências derivadas sem que se considerem, no terreno do jazz, as questões ligadas à condução de vozes, como Schenker propôs. ${ }^{17}$ Por outro lado, na história do jazz, há um período muito identificado com um certo tipo de modalismo que se situa entre o Be Bop e o Free Jazz que não é somente o $\mathrm{Cool}^{18}$, e se deu principalmente a partir das gravações de músicos que trabalharam com o trompetista norte-americano Miles Davis.

By the late 1950`s Davis [Miles] had tired of bop structures, and turned to a new approach formulated at this time by Gil Evans and Bill Evans and later called 'modal playing' [...]. However, the use of modes in Davi's recordings of 1958-9 (Milestones, So What, Flamenco Skcetches) had less significance for the future than the slowing of harmonic rhythm. In place of fast moving functional chord progressions, Davis used diatonic ostinatos (vamps), drones, half-tones oscillations familiar from flamenco music [...] (The New Groove Dictionary of Jazz, 1996, p.273)

Entretanto, diferentemente das relações de analogia aqui propostas entre procedimentos tonais ligados à centralidade político-econômica, tanto do eixo FrançaAlemanha-Itália quanto do eixo Rio-São Paulo, em relação aos modalismos encontrados no resto da Europa e do mundo e no Norte e Nordeste brasileiros, o modalismo no jazz se dá na centralidade do gênero que é pautada, sobretudo, pela direção estética e pelos músicos que participaram dos grupos do trompetista Miles Davis.

Músicos como Bill Evans Wayne Shorter, John Coltrane, Herbie Hancock, para citar alguns, trabalharam o modalismo e sua expansão a partir de Miles Davis. Mas como ele se dá e no que ele se diferencia dos casos anteriores (românticos) e posteriores, principalmente da música popular do Brasil nos anos 1960?

\footnotetext{
${ }^{17}$ Muito embora se discutam e se apliquem técnicas de orientação Schenkeriana ao repertório popular.

${ }^{18}$ Este está ligado não somente a procedimentos harmônicos, mas também à maneira "fria" de se tocar e se relacionar com o público, em oposição ao Hot Jazz de Louis Amstrong. Do ponto de vista étnico, procurava-se negar a postura do negro como um animador do público branco.
} 


\subsection{Compositores escolhidos dentro dos contextos Históricos e Estéticos: Canção de Protesto e Nacionalismo}

A dissertação de mestrado do autor da presente tese (TINÉ, 2001) investigou três compositores da música popular do Brasil de diferentes períodos: Pixinguinha, Garoto e Tom Jobim. Procurou-se traçar um perfil comparativo apontando as principais diferenças de procedimentos, principalmente entre Pixinguinha e Tom Jobim, e vendo Garoto como uma espécie de ponte dentro dessa perspectiva. No caso do presente trabalho, pretende-se apontar alguns procedimentos comuns que perpassam por compositores de um mesmo período: Baden Powell de Aquino (1937-2000), Milton Nascimento (1942) e Eduardo de Góes Lobo (1943), compositores-chave, entende-se, ligados ao período pós-bossa nova da história da música popular do Brasil.

\subsubsection{Edu Lobo e Mário de Andrade:}

Em um depoimento dado à importante revista “Civilização Brasileira” da década de $1960^{19}$, Edu Lobo demonstra que se pauta esteticamente pelo famoso Ensaio sobre Música Brasileira (1928), de Mário de Andrade. Alguns trechos ${ }^{20}$ parecem ter “feito a cabeça” de muito compositores populares de então, inclusive o próprio Tom Jobim:

Trata-se do momento em que o Mário de Andrade modernista se transforma em Mário de Andrade nacionalista. Não há ruptura drástica entre uma e outra coisa ainda, mas ela se dará progressivamente. Mais tarde, razões ideológicas que o levaram a se aproximar do partido comunista, provocarão a ruptura com os projetos da semana de 1922, fortemente internacionais, na conferência intitulada "Movimento Modernista", de 1942. (COLI, 2006, p.127)

À parte dos aspectos radicais de algumas posições, o procedimento preconizado por Mário de Andrade para a realização da nacionalização da arte, em especial a nacionalização da música, era o da apropriação do folclore. Mesmo ao final da vida, quando já adquirira um

\footnotetext{
${ }^{19}$ Revista Civilização Brasileira. Rio de Janeiro, No 3, 1965.

20 “Si um artista brasileiro sente em si a força do gênio, [...], está claro que deve fazer música nacional. [...] E si o artista faz parte dos 99 por cento dos artistas e reconhece que não é gênio, então é que deve mesmo fazer música nacional. [...] Todo artista brasileiro que fizer arte nacional é um ser eficiente com valor humano. O que fizer arte internacional ou estrangeira, se não for gênio, é um inútil, um nulo. E é uma revendissima besta.”

(ANDRADE, s/d, p.19)
} 
posicionamento bastante crítico em relação a um certo tipo de nacionalismo fácil, que se aproxima do exótico, Mário de Andrade coloca na voz de seu personagem Janjão:

A música brasileira ainda não pode perder de vista o folclore. Se perder, se estrangeirizará completamente. Como sucede com os sistematizadores do serialismo integral. [...] veremos que isso de "criação livre" é uma quimera. Até esse slogan deslumbrante que é a "cultura universal” não passa de tolice de parlapatões ou interessados. [...] no momento presente a música brasileira não está em condições de permitir aos seus compositores a pretensão de criar "livremente". O compositor brasileiro que perder o folclore de vista e de estudo, [...] fatalmente se desnacionalizará e deixará de funcionar. [...] a invenção livre só virá mais tarde, quando a criação musical estiver tão rica, complexa e explícita em suas tendências particulares psicológicas, que o compositor possa desde a infância viver cotidianamente dentro dela, se impregnar dela, e a sentir como um instinto. (ANDRADE, 1989, p.150-151)

Nessa última fase de Mário de Andrade começava a existir uma diferença mais acentuada entre música popular e folclórica. O primeiro termo ainda aparece em seu Ensaio, significando, entretanto, o segundo. Para Tinhorão (s/d), em Pequena História da Música Popular, essa diferença se dá entre as manifestações rurais e urbanas. Todavia, com o avanço dos meios de comunicação de massa, acredita-se que tais linhas divisórias adquirirão outros contornos, como afirma o compositor Gilberto Mendes em seu texto no livro O Balanço da Bossa, que apontou para uma definição mais contemporânea da música popular.

A música popular é cultura de massa; opera, portanto, na faixa da
‘comunicação persuasiva', pretendendo convencer o ouvinte com base
naquilo que ele já conhece, deseja, quer ouvir. [...] Mas no círculo vicioso da
comunicação compositor-ouvinte, há um momento em que, pela resposta do
ouvinte, o compositor se cientifica de que tudo vai indo bem; e que ele pode
[...] impor uma pesquisa nova. É o momento em que o artista, consciente de
sua responsabilidade frente ao povo, aproveita para elevá-lo em seu gosto,
oferecendo-lhe algo mais elaborado que o force a participar com mais
inteligência na sua apreciação”. (MENDES In: CAMPOS, 1993, p.134-135)

\subsubsection{Música Viva e Popular no Estado Novo}

A partir das premissas dadas por Mário de Andrade, o nacionalismo vai reger a produção musical erudita brasileira pelo menos até o aparecimento de Koellreutter e a criação do grupo Música Viva, em 1939. Este seria o primeiro abalo na coluna vertebral dessa produção. 
[...] um dos pontos chaves da pregação de Koellreuter e do'grupo música viva’ era a liberação da música dos últimos laços que a ligavam ao pensamento romântico, ou seja, a subserviência a roteiros literários e a temática sentimental: a música deveria reconquistar sua total independência, definindo-se por sua própria realidade, sendo seu próprio objetivo. (NEVES, 1976, p.92)

Verifica-se, portanto, uma postura diametralmente oposta àquela da funcionalidade da arte defendida por Mário de Andrade quando se almeja a “total independência”. Ao mesmo tempo, estava sendo construído no meio musical popular brasileiro um modelo de exaltação nacional através do samba, e principalmente através dos signos de exaltação encontrados na obra Aquarela do Brasil, de Ary Barroso. E isso se deu quase concomitantemente com a relação do compositor Heitor Villa-Lobos com o Estado Novo. Heitor Villa-Lobos, em 1930, apresentou um projeto de educação musical à Secretaria de Educação do Estado de São Paulo e, em 1932, foi convidado por Anísio Teixeira, o secretário de Educação do Distrito Federal da época, a introduzir o ensino de música nas escolas públicas através do canto coral.

Com esse rápido perfil do homem que comandava as áreas de humanidades da época, podemos re-enfocar Heitor Villa-Lobos que, durante a ditadura do Estado Novo, estará organizando concentrações orfeônicas as quais chegarão a reunir cerca de 40 mil escolares sob sua batuta. Não há como negar que nesses anos sua produção tenha sido de grande ajuda na propaganda do regime. Observemos que, em 1944, Villa-Lobos chega a realizar uma turnê pelos Estados Unidos como parte da chamada 'política da boa vizinhança' praticada pelo presidente Franklin Roosevelt no contexto da Segunda Guerra Mundial. (JARDIM, 2002, p.30)

Quando se lembra que a primeira gravação de Aquarela do Brasil foi realizada em 1939, ano da partida de Carmen Miranda para os Estados Unidos da América, vê-se que uma série de signos, um ideário brasileiro estava sendo constituído, ainda que tal processo pudesse ser completamente inconscientemente por parte dos compositores. Entretanto, o que se busca aqui na relação do nacionalismo e a canção de protesto é exatamente aquela posição conscientemente estético-ideológica que marcou a produção de grande parte dos anos 1960. A transformação da Aquarela do Brasil em paradigma se dá em pleno período do Estado Novo.

[...] o samba de Ary Barroso transformou-se em emblema sonoro interno para os compositores populares [...] Estes símbolos são costurados, no paradigma exaltativo, pelo sentimento de reconhecimento, aceitação e amor para com os mesmos, pois supõe-se sejam valores compartilhados, igual e integralmente, por todos brasileiros. (SOARES, 2002, p.40) 


\subsubsection{Referências Nordestinas}

Se é certo que o samba se tornou, principalmente através de Ary Barroso e Dorival Caymmi, o paradigma musical popular do Brasil nos anos 1940, paralelamente uma outra identidade começa a se construir através do acordeonista e cantor Luiz Gonzaga do Nascimento (1912-1989). Após tentar a sorte executando gêneros estrangeiros juntamente com o samba e o choro carioca, é na volta às suas origens musicais da cidade de Exu, estado de Pernambuco, que ele alça seu sucesso no Rio de Janeiro. A partir daí, ele constrói um personagem típico, vestindo-se como cangaceiro, ou seja, cria um estereótipo do povo nordestino e faz muito sucesso com o lançamento da dança e do ritmo do baião. Na década seguinte, coube ao paraibano Jackson do Pandeiro (José Gomes Filho, 1919-1982) seguir esse caminho com danças e ritmos exóticos ligados à tradição do coco para o eixo Rio-São Paulo. Jackson também marca o início da música popular na era da televisão, pois seus números coreográficos fizeram bastante sucesso no início da história desse meio de comunicação.

Se para a construção de um ideário musical nacional através da utilização de novos ritmos e melodias além do samba se deu dentro, como se verá, da perspectiva da apropriação do material popular pelos compositores cariocas da década de 1960 abordados nesse trabalho, é certo que tal não ocorreu somente através da consulta às fontes etnográficas. Acredita-se que o próprio sucesso desses compositores-intérpretes (Luiz Gonzaga e Jackson do Pandeiro) no eixo Rio-São Paulo foi essencial para tal construção.

\subsubsection{Congresso de Praga e o Teatro de Arena}

É nesse contexto que o grupo de Koellreuter apresenta um revés quando dois compositores, Cláudio Santoro e Guerra-Peixa, ligados ao mestre alemão, direcionam-se ao nacionalismo por questões ideológicas advindas do Congresso de Praga, de 1948, principalmente as de Andrei Alexandrovitch Jdanov, porta-voz da cúpula do Politburo do Comitê Central do Partido Comunista da antiga União das Repúblicas Socialistas Soviéticas, “cujo discurso determinaria as diretrizes gerais e a linha dominante dessa histórica conferência”. (RICCIARDI, 1997, p.175)

1948 será um ano chave na evolução da música em todo o mundo. De 20 a 29 de maio reúne-se em Praga o " $2^{\circ}$ Congresso Internacional de Compositores e Críticos Musicais”, daí saindo recomendações que deveriam levar a todo o mundo os princípios básicos do 'realismo-socialista', 
recomendações que podem ser sintetizadas em quatro pontos fundamentais: os compositores devem fugir do subjetivismo e expressar os sentimentos e as altas idéias progressistas das massas populares - os compositores devem aderir à cultura nacional de seus países e defendê-la de falsas tendências cosmopolitas. - os compositores devem aplicar-se especialmente à música vocal [...] - os compositores, críticos e musicólogos devem trabalhar pratica e ativamente para liquidar o analfabetismo musical e educar musicalmente as massas. (NEVES, 1981, p.119)

Não se quer dizer com isso que Mário de Andrade, ao se aproximar do realismo socialista, seguisse, por assim dizer, a "cartilha” do partido, da mesma forma que Villa-Lobos ao se aproximar do regime de Getúlio Vargas. Acredita-se que ambos não podem ser simplesmente classificados como "jdanovista[s] antes de Jdanov", ou seja, as perspectivas humanistas e musicais de ambos não deveriam estar determinadas a partir de um ponto de vista burocrático associado, em última análise, a outro regime totalitário.

Nos anos 1950, grande parte da intelectualidade brasileira se alinhava com idéias de esquerda. No Teatro de Arena, em São Paulo, artistas "tinham uma perspectiva mais enraizadamente brasileira para ser atingida” (MELO, 2003, p.50). Em oposição ao TBCTeatro Brasileiro de Comédia, o Teatro de Arena realizou um novo repertório constituído de obras como Eles Não Usam Black-tie (1959), Chapetuba Futebol Clube (1959), Revolução na América do Sul (1960). Tais espetáculos, levados ao Rio de Janeiro no começo da década de 1960, causaram grande interesse no meio musical popular. Logo, alguns compositores da bossa nova entraram em contato com os atores dos elencos e houve, segundo o escritor Zuza Homem de $\mathrm{Melo}^{21}$, grandes reuniões e estas deram origem ao CPC-Centro Popular de Cultura, o braço cultural da UNE-União Nacional dos Estudantes de então.

[...] os músicos freqüentadores do CPC, (...) passaram a conviver com um ambiente diferente do que estavam acostumados, realidade social brasileira, em que a abordagem política ocupava o centro do debate (...). O tema foi se incorporando como uma nova preocupação entre esses músicos, e o passo seguinte à contaminação inicial foi inevitável: os compositores que trabalhavam a música passaram a fazer parcerias com quem dominava a palavra, isto é, o pessoal do teatro e do cinema. (MELO, 2003, p.50)

Nesse contexto, o acabamento poético associado a procedimentos musicais híbridos, como as aquisições harmônicas da bossa nova e impressionismo, o melodismo brasileiro e o cuidado com o acabamento dos arranjos tornam o território da canção, de certa forma, nem

\footnotetext{
${ }^{21}$ MELO, 2003, p.50.
} 
erudito nem popular quando comparados, por exemplo, às modinhas de Villa-Lobos e Tom Jobim.

\subsubsection{Música Nova e Canção de Protesto na Década de 1960}

Entretanto, a produção erudita nos anos 1960 passa a sofrer novas transformações. A morte de Heitor Villa-Lobos, em 1959, foi, segundo José Maria Neves, um dos fatores que contribuiu para o enfraquecimento do nacionalismo, muito embora o mesmo autor coloque Villa-Lobos acima de tais classificações. ${ }^{22} \mathrm{O}$ golpe de misericórdia foi dado pelo movimento Música Nova (1963), com os compositores Willy Correa de Oliveira, Damiano Cozzella, Rogério Duprat e Gilberto Mendes. "E logo o grupo vai definir mais claramente sua postura: em 1963 a revista ‘Invenção’ publica o manifesto ‘Por uma nova música brasileira’, no qual são explicitadas as orientações do grupo” (NEVES, 1981, p.163).

Coube à música popular brasileira dos anos 1960, mais especificamente aquela dos festivais, dar continuidade ou pelo menos seguir os mesmos passos da apropriação do folclore e a transposição não mais para o plano da erudição, mas para o plano da cultura de massa, o plano das músicas difundidas pelos rádios, discos e televisão, o qual cada vez mais define apropriadamente o conceito "música popular" em termos contemporâneos. Para J. R. Tinhorão, além da divisão rural versus urbano, a divisão entre classes sociais define as fronteiras de tais gêneros. Daí ele ter sido um grande crítico da bossa nova e, apesar de considerar a “canção de protesto” bem-intencionada, enfoca a questão de que não é a classe popular ou socialmente mais baixa que está produzindo tal música, mas, sim, a classe média e a classe média alta. A “Canção de Protesto”, embora não tenha sido o único gênero a marcar a década com a temática social tão característica do período, foi assim diagnosticada pelo autor:

[...] os jovens estudantes partiam de uma posição de superioridade da sua cultura, e propunham-se [...] a assumir paternalistamente a direção ideológica do povo, comprometendo-se a revelar-lhe as causas de suas dificuldades sob a forma de canções glosando a dura realidade da pobreza e do subdesenvolvimento. [...] Os compositores da geração posterior à criação da bossa-nova - entre eles o nacionalista musical Edu Lobo, e o jovem

\footnotetext{
22 “O final da década de 50, que marca o desaparecimento do nacionalismo como tendência dominante na criação brasileira, coincide com o falecimento de Villa-Lobos, compositor que, mesmo independendo totalmente dos princípios estéticos do nacionalismo e das soluções técnicas comuns aos adeptos desta corrente, pode ser considerado o representante máximo das aspirações nacionalistas: a expressão da terra e da raça, a tendência ao neoclassicismo, a fé na funcionalidade da arte. O desaparecimento do grande mestre contribuiu certamente para o desaparecimento rápido desta orientação musical. [...] A morte de Villa-Lobos deixou um vazio no nacionalismo brasileiro.” (NEVES, 1976, p.145) Apesar disso, a produção de C. Guarnieri continua em plena atividade durante a década de 1960.
} 
estudante de sociologia Sidney Miller - sentiram em 1965 a necessidade de insistir na tese de Carlinhos Lyra, procurando contato com a cultura popular. [...] A partir de 1965, concorrendo já no mercado das cidades com o novo estilo musical internacionalizado pelos Beatles [...], os componentes da segunda geração da bossa-nova - Edu Lobo, Geraldo Vandré, Chico Buarque de Holanda, principalmente - lançam, através de festivais de música popular, os primeiros produtos bem-sucedidos da nova fase, que já começava a quase nada ter de bossa-nova: Arrastão, de Edu Lobo, [...], Disparada, de Geraldo Vandré e Theo de Barros, [...] (TINHORÃO, s/d, p.231 - 234)

Dessa forma, a "procura de contato com a cultura popular” de Carlos Lyra se assemelha muito ao "fenômeno universal do aproveitamento do folclore" de Mário de Andrade. No entanto, é importante lembrar que Mário de Andrade, conforme mencionado, também criticou muito alguns compositores nacionais pelo uso de um exotismo fácil, apontando uma falta de profundidade e de pesquisa. Paralelamente, o compositor popular geralmente sai de uma experiência vivida no seu meio o que torna mais rara essa artificialidade no uso dos elementos nacionais. Observe-se, por exemplo, a descrição do processo de Baden Powell na criação dos afro-sambas, alguns analisados nesse trabalho pelo letrista das mesmas obras, o poeta Vinícius de Moraes:

Quando, há quatro anos, Baden Powell e eu começamos a compor pra valer [...], uma das coisas que mais o fascinava era ouvir um disco que meu amigo Carlos Coqueijo me trouxera da Bahia: uma gravação ao vivo, de sambasde-roda e cantos de candomblé, com várias exibições de berimbau em suas diversas modalidades rítmicas. Nesse meio tempo, Baden deu um pulo a Salvador, onde teve a oportunidade de ver e ouvir candomblé e conviver com gente 'por dentro' do assunto. A Bahia fez-lhe uma impressão enorme. Foi quando saiu nosso samba "Berimbau" [...] e o "Samba da Bênção", de "balanço" nitidamente baiano. (MORAES In: POWELL, 1966)

Percebe-se aqui uma apropriação de gênero folclórico com um diferencial: através dos “meios de reprodução mecânica”, ou seja, a gravação. Mesmo assim, Vinícius descreve que o compositor também foi assistir in loco tais manifestações, não derivando daí nenhuma artificialidade. Ainda que os afro-sambas não sejam considerados canções de protesto como tal ou canções da era dos festivais, algumas características os colocam ao lado das canções de Edu Lobo, por “exalarem” uma atmosfera dos 1960, a temática negra e a mitologia do candomblé nas letras, além dos já citados ritmos. O long playing “Afro-sambas” foi lançado em 1966, pela gravadora Elenco. Se lembrarmos que Coisas, de Moacir Santos ${ }^{23}$, estavam em

\footnotetext{
${ }^{23}$ Long playing lançado pela gravadora Forma, em 1965.
} 
pleno vigor e que o ativismo negro estava em ascensão com Luther King, Malcon X, a versão do herói negro Zumbi pelo Teatro Arena, pode-se ter melhor idéia do que estava acontecendo e de como os afro-sambas estavam sintonizados com o período. ${ }^{24}$ Esse ativismo fez parte, juntamente com outros movimentos dos sessenta, daquilo que o autor Stuart Hall chamou de descentramento da identidade cultural na modernidade, após os impactos de Marx, Freud, Saussurre e Foucault.

O quinto descentramento [...] é o impacto do feminismo, tanto como crítica teórica quanto como um movimento social. O feminismo faz parte daquele grupo de 'novos movimentos sociais' que emergiram durante os anos sessenta [...], juntamente com as revoltas estudantis, os movimentos juvenis contraculturais e antibelicistas, as lutas pelos direitos civis, os movimentos revolucionários do "Terceiro Mundo”, os movimentos pela paz e tudo aquilo que está associado com “1968”. (HALL, 2003, p.43-44)

É neste contexto que se dá o aparecimento do cantor e compositor negro Milton Nascimento, “carioca de nascimento e minero por adoção”. Vemos em músicas como Canção do Sal processos muitos semelhantes aos de Upa, Neguinho, de Edu Lobo e Gianfrancesco Guarnieri, como será demonstrado. Em Morro Velho pode-se especular se, em última análise, não se trata da questão da reforma agrária, ainda que de um ponto de vista de um eu-lírico subjetivo. Essas duas composições figuram no $1^{\circ}$ long playing de Milton Nascimento, de título homônimo ${ }^{25}$, lançado em 1967, com arranjos de Luís Eça e texto do encarte de Edu Lobo.

Outro dado coincidente é o arranjador do álbum Afro-sambas ser o maestro GuerraPeixe, que foi um nacionalista da segunda geração e pesquisador do folclore nordestino. Também Edino Krieger, pertencente à mesma geração de Guerra-Peixe, participou como compositor de diversos festivais de música popular dos $1960^{26}$.

Não se trata, aqui, de se demonstrar uma conexão impensada até então, mas de enfatizá-la. O próprio Manifesto, do CPC, escrito por Carlos Eduardo Martins, aproximava-se, segundo Arnaldo Contier, de “algumas teses defendidas por Jdnanov no II Congresso de Praga de 1948” (CONTIER, 1998, p.7) Além disso, conectou os autores da canção de protesto por excelência - Edu Lobo e Carlos Lyra - ao nacionalismo da música erudita. Enquanto Edu

\footnotetext{
24 “Essas antenas que Baden tem ligadas para a Bahia e, em última instância para a África, permitiram-lhe realizar um novo sincretismo: carioquizar, dentro do espírito do samba moderno, o candomblé afro-brasileiro, dando-lhe ao mesmo tempo uma dimensão mais universal”. (MORAES In: POWELL, 1966)

${ }^{25}$ NASCIMENTO, Milton. Milton Nascimento. A \& M, 1967.

${ }^{26}$ As canções Fuga e Antifuga (letras de Vinícius de Moraes) e Passacalha, ambas de Edino Krieger, classificaram-se em $4^{\circ}$ lugar nos II e III Festival Internacional da Canção, em 1967 e 1968, respectivamente.
} 
Lobo trabalha com a introdução de elementos nordestinos na bossa nova, que trazem as características musicais abordadas neste trabalho, Carlos Lyra trabalha na vertente do samba de morro, aproximando-se, juntamente com a cantora Nara Leão, de compositores como Zé Kéti, Nelson Cavaquinho, Cartola, etc.

As músicas escritas por Edu Lobo e Carlos Lyra refletiram, de um lado, algumas dimensões político-estéticas de uma memória coletiva construída pela esquerda durante os anos 60, centrada nos temas sobre o morro e o sertão, como verdades inquestionáveis, sob o ponto de vista de uma determinada leitura sobre a História do Brasil, e, de outro, alguns traços técnico-estéticos já consolidados pelos compositores eruditos, tais como Villa-Lobos, Camargo Guarnieri, Lorenzo Fernandez e Francisco Mignone. (CONTIER, 1998, p.25)

Caberia aqui a pergunta: não seria próprio da música popular o tratamento do material de origem étnica? Isto parece ser mais apropriado para a música anterior ao advento dos meios de comunicação de massa, mas, ainda assim, como explicar os gêneros derivados da polca e da valsa no século XIX? A medida que a música popular se comercializa, constata-se um afastamento histórico das "raízes” quando o próprio fazer musical é determinado pela indústria cultural $^{27}$. Por isso, a Canção de Protesto se encontrou historicamente cercada por tendências de cunho internacional, como a bossa nova, a jovem guarda e, posteriormente, a tropicália.

\begin{abstract}
A construção e sacralização desse imaginário musical num discurso marcadamente ideológico implicou o afloramento de práticas consideradas pelos defensores da brasilidade como alienantes, tais como os temas da Bossa Nova sobre a mulher, o sorriso, o violão, a flor, o mar de Copacabana; o iê-iê-iê, o rock, defendido pelos artistas da Jovem Guarda ou com os antropófagos do movimento tropicalista. (Ibid., p.27)
\end{abstract}

Este último, o tropicalismo, trataria de almejar uma síntese entre a cultura de massa e as vanguardas através da inspiração no manifesto antropofágico de Oswald de Andrade e o movimento modernista da década de 1920. Tal anseio se torna patente quando o arranjador mais ativo dos compositores desse movimento - Caetano Veloso, Gilberto Gil, Os Mutantes foi Rogério Duprat, um dos mentores do movimento Música Nova. Correndo o risco de fazer polarizações simplistas, pode-se dizer que nos anos 1960 a Canção de Protesto tendeu para

\footnotetext{
${ }^{27}$ Assunto também discutido dissertação de mestrado do autor da presente tese. Ver TINÉ, 2001.
} 
Mário de Andrade e para o Teatro Arena e, no pólo oposto, o tropicalismo tendeu a Oswald Andrade e ao Teatro Oficina, de José Celso Martinez Correa. ${ }^{28}$

\subsubsection{Hermeto Pascoal e sua Escola}

É desse ambiente musical que surgirá o grupo instrumental Quarteto Novo. Advindo do Trio Novo, formado pelos músicos Theo de Barros, Heraldo do Monte e Airto Moreira, incorporaria aquele que viria a ser um dos compositores e instrumentistas brasileiro mais importantes da segunda metade do século XX: Hermeto Pascoal (1936). Em um ambiente dominado pelos trios de orientação jazzística típica da era da bossa nova ${ }^{29}$, o Quarteto Novo começou a incorporar instrumentos característicos, como a viola caipira e instrumentos brasileiros de percussão e, ao mesmo tempo, a acompanhar cantores como Geraldo Vandré e Jair Rodrigues, a exemplo do II Festival da TV Exelcior, de 1966, na canção Disparada, composta por Geraldo Vandré e Theo de Barros.

É interessante notar que, no compacto simples lançado em 1967, o Quarteto Novo gravou duas canções tocadas instrumentalmente: Fica Mal com Deus, de Geraldo Vandré, e Ponteio, de Edu Lobo e Capinan ${ }^{30}$, exatamente aquelas músicas dos dois compositores que, ao lado de Carlos Lyra, estavam ligados à Canção de Protesto. Tal perspectiva explica as posições ideológicas tomadas pelos músicos citados no começo deste trabalho, advindos da linha do "mestre dos sons” e toda uma geração de músicos por ele influenciada. Pode-se lembrar, por exemplo, do grupo paulista Pau Brasil que, inspirado no Manifesto Antropofágico de Oswald Andrade, fez parte, juntamente com outros grupos e artistas, do crescimento da música instrumental paulista nos anos 1980 que, ligados principalmente à gravadora Som da Gente ${ }^{31}$, foi o grupo de apoio do disco Dança da Meia-Lua (Edu Lobo e Chico Buarque $)^{32}$.

\footnotetext{
${ }^{28}$ Uma alusão a tal conexão encontra-se na capa do long playing Estrangeiro, de Caetano Veloso, lançado em 1989. Nele há o cenário da primeira montagem da peça O Rei da Vela, de Oswald de Andrade, do Teatro Oficina, em 1967.

${ }^{29}$ Zimbo Trio, Jongo Trio, Tamba Trio, apenas para citar alguns deles.

${ }^{30}$ Ver discografia.

${ }^{31}$ Exatamente a gravadora de Hermeto Pascoal nos anos 1980.

${ }^{32}$ Som Livre, 1985.
} 


\subsubsection{Décadas de 1980 e 1990 e a Globalização}

Na década de 1990, com o advento da globalização, tornaram-se comuns certas fusões musicais de músico indígena com cantor pop, cantor de rock e paquistanês juntos, músico pop e orquestra de percussão afro, etc. O mesmo processo que existiu no surgimento de gêneros populares como o samba, o baião e o jazz no século XX aconteceu, entretanto, dentro de uma perspectiva de fusão com outros estilos preexistentes. O etnomusicólogo brasileiro José Jorge de Carvalho vê com extrema desconfiança tal processo, além de diagnosticar uma despolitização e dessacralização, principalmente relacionadas aos gêneros de origem afrobrasileira.

La questión de entender hoy las tradiciones musicales pasa no solamente por uma discussión de formas y géneros, sino también por una questión de geopolítica estética. Estamos ablando de tradiciones que son trasladas de uma parte del mundo a otras a través de circuitos intensos de músicos, productores y mediadores. [...] Desde los años ochenta, uno de los modos de expansión del imaginário de la música popular comercial ocidental (sobretudo anglosajón, que es el más poderoso), fue estabelecer vínculos com las tradiciones africanas a través de estructuras empresariales de cooperación muy desiguales y específicas. [...] Cuando la música, tradicional o sagrada, pasa a la música popular (tales como el interes del turismo, el entretenimiento, el consumo ampliado) hay en esas negociaciones un cierto momento, en todos los casos que conozco, en que lá comunidad pierde la noción de la naturaleza de las consecuencias estéticas, ideológicas o políticas de esas negociaciones. (J. de CARVALHO, 2003, p.6)

O autor cita uma série de exemplos nesse artigo, alguns pertinentes a este trabalho, mas serão comentados no momento oportuno. Entretanto, trabalha-se aqui na perspectiva de músico, ou seja, o olhar para algumas comunidades permanece identificado com a questão musical, fato que não diminui a importância dos outros elementos. Ou seja, o valor de um exemplo escolhido não se pauta aqui pelo papel de resistência político-cultural de uma determinada manifestação e o conhecimento dessas manifestações se deram através dos portavozes populares.

\subsection{Objeto de Pesquisa}

A partir dos dados expostos nesta introdução, o presente trabalho abordará traços da música étnica brasileira relacionada a três importantes compositores da música popular do Brasil na década de 1960: Baden Powell, Edu Lobo e Milton Nascimento, sendo esta já a ordem histórica de aparecimento e de impacto que fizeram no contexto da música popular 
brasileira do período, principalmente sob o ponto de vista dos procedimentos ligados ao modalismo na música popular, seja ele de viés melódico ou, como se pretende demonstrar, harmônico. Ainda importante será o cotejamento dos dois elementos, ou seja, quando o comportamento harmônico e o fato melódico se derem modalmente. Quer dizer, sendo este elemento, o do modalismo, um importante instrumento de caracterização de uma identidade, esteja ela ligada ao Brasil de uma maneira geral ou ao Nordeste brasileiro, a detecção desse procedimento e, principalmente, suas diversas apropriações, são de fundamental importância para o entendimento do período histórico ressaltado e de como suas bases podem, juntamente com outros processos, ter alicerçado boa parte do que chamamos hoje de música popular brasileira.

Cabe também ressaltar que cada compositor foi referencial para o próximo, ou seja, os afro-sambas de Baden causaram impacto em Edu Lobo que, por sua vez, influenciou Milton Nascimento com suas canções de matiz nordestina. Nesse ponto foi necessária a inclusão dos autores nordestinos mencionados - Luiz Gonzaga e Jackson do Pandeiro - na medida em que eles também fazem parte desse processo de apropriação do material étnico, ainda que integrados em tais manifestações, como será comentado em capítulo próprio.

Em relação às manifestações étnicas foram selecionadas gravações e transcrições de exemplos relacionados ao universo cultural e biográfico de cada autor: as manifestações afrobrasileiras da Bahia para o caso de Baden Powell; a música nordestina, sobretudo de Pernambuco e proximidades para Edu Lobo e congadas e moçambiques mineiros no caso de Milton Nascimento.

De antemão, a partir da escuta dos exemplos mineiros, não foi possível estabelecer conexões entre as duas partes, principalmente sob o ponto de vista do viés aqui desejado, o viés modal. Tal fato será tema de um aprofundamento específico nas Considerações Finais desta tese.

Como no caso do mestrado (TINÉ, 2001), não se trabalhou apenas com partituras de songbooks e afins, mas, sobretudo, com o cotejamento dessas versões com gravações históricas, cujo critério de escolha foi o da primeira gravação na qual o compositor figurasse de alguma forma (cantando, tocando, arranjando, etc.) como intérprete. Portanto, todas as transcrições apresentadas no decorrer do trabalho são de feitura do pesquisador. Do contrário, as fontes bibliográficas respectivas estão mencionadas. 


\section{Revisão dos Parâmetros Analíticos}

Na citada dissertação de mestrado (TINÉ, 2001), tentou-se explicar da maneira mais clara possível todos os critérios harmônicos, fraseológicos e redutivos para a análise daquele material, baseados principalmente na bibliografia de Arnold Schoenberg, Leon Stein, Joaquin Zamacoiz e Allen Forte. ${ }^{33}$ Ocorre que, dentro da perspectiva de um novo material, os conceitos tão úteis e frutíferos daquela ocasião não se encaixaram tão bem para o objetivo proposto.

No caso da fraseologia, cabe lembrar o paralelo que Schoenberg (1991, p. 51) - e muitos outros de diferentes maneiras ${ }^{34}$ - fez, em uma nota de rodapé, a respeito do objetivo da música: “O real propósito da construção musical não é a beleza, mas a inteligibilidade”. Para justificar tal propósito, o autor dá ênfase na repetição, ou seja, a repetição é o fator gerador da inteligibilidade, ainda que do ponto de vista composicional Schoenberg pareça buscar exatamente o oposto no período do atonalismo livre.

Por conseqüência, a repetição de motivos, frases, antecedentes e de seções inteiras serão fatores geradores de inteligibilidade, ainda que, segundo o autor, a repetição excessiva corra o risco da monotonia. Nesse contexto, abundam analogias com a linguagem verbal. A teoria musical toma de empréstimo diversos conceitos gramaticais ligados a esse modo de comunicação. Conceitos como “frase”, “linguagem composicional”, “idiomático” são alguns exemplos disso.

A presente tese pretende trabalhar com a hipótese da analogia com a arte poética como elemento que estrutura a fraseologia musical. Não que a poesia esteja de fato presente como texto, mas a organização dos materiais se dá, pelo menos numa primeira instância, de maneira poética. Por isso, aqui, o motivo musical e suas repetições poderiam ser vistos como análogos às rimas, aliterações ou assonâncias ${ }^{35}$ e não como um elemento de inteligibilidade. Mesmo as repetições de frase poderiam ser vistas com esse objetivo, o de rimar musicalmente. No caso da dissertação mencionada, trabalhou-se, como hipótese de modelo num primeiro momento e como conclusão posteriormente, com as seguintes categorias fraseológicas: Estruturas Binárias classificadas como Período ou Sentença (regulares ou irregulares) e Estruturas

\footnotetext{
${ }^{33}$ Respectivamente nas obras Fundamentos da Composição Musical (1991), l, Structure and Style (1979), Curso de Formas Musicales (1982) e Introduction do Schenkerian Analisys (1985).

34 “Acredito que a composição não se ensina. Entretanto, o que sempre trabalhei em classe foi o entendimento da música enquanto linguagem [grifo nosso]. É necessário aprender a falar. E para isso é fundamental que se pratique essa linguagem. Em minhas aulas partia da base pessoal de cada aluno, que chamo de 'acontecimento acústico’, e procurava transformá-lo em um ‘acontecimento linguístico’. Sem isso não é possível compor.” Entrevista de Willy Correa de Oliveira concedida à Revista Concerto. Ano XI. N. 115, março de 2006.

${ }^{35}$ Ver GOLDSTEIN, Norma: 2005, Cap. 7 e 8.
} 
Ternárias (regulares e irregulares), baseados na bibliografia citada. Dentro dessas categorias, podem se desenvolver subgêneros como as cadeias de frases no caso da sentença ( $a$ a'a” etc.) e da barform ( $a$ a $b$ ) como uma das possibilidades de estrutura ternária, baseados em Green (1964).

Cabe aqui propor o pensar dessas estruturas como possibilidades de quadras e tercetos musicais, respectivamente. Baseando-se na analogia proposta e no sentido de ampliar as possibilidades estruturais, pode-se pensar em uma estrutura musical análoga ao Verso Branco, na qual as frases se mantêm na métrica (quatro frases para Período ou Sentença e três para Estrutura Ternária), porém, com ausência de repetição. Como exemplo dessa possibilidade, apresento a seção A do frevo Freio a Óleo ${ }^{36}$, de 1950, do compositor pernambucano José Menezes. Observa-se que nenhuma frase se repete, apenas o motivo dos anacruses do $2^{\circ}$ e $10^{\circ}$ compassos e, apesar disso, a quadratura está perfeita, com quatro frases em 16 compassos, incluindo a frase cadencial que finaliza a seção. Por outro lado, pode-se considerar a terceira frase $c$ como uma variação da frase $a\left(a^{\prime}\right)$, o que colocaria tal estrutura dentro do esquema do período. Entretanto, talvez esta ausência de repetição fraseológica seja uma característica importante do frevo, como demonstram os temas Duda no Frevo (Senô), Gostosinho e Gostosão” (Nelson Ferreira) e Corisco (Lourival Oliveira), possibilidade esta que deve ser aprofundada em outra pesquisa.

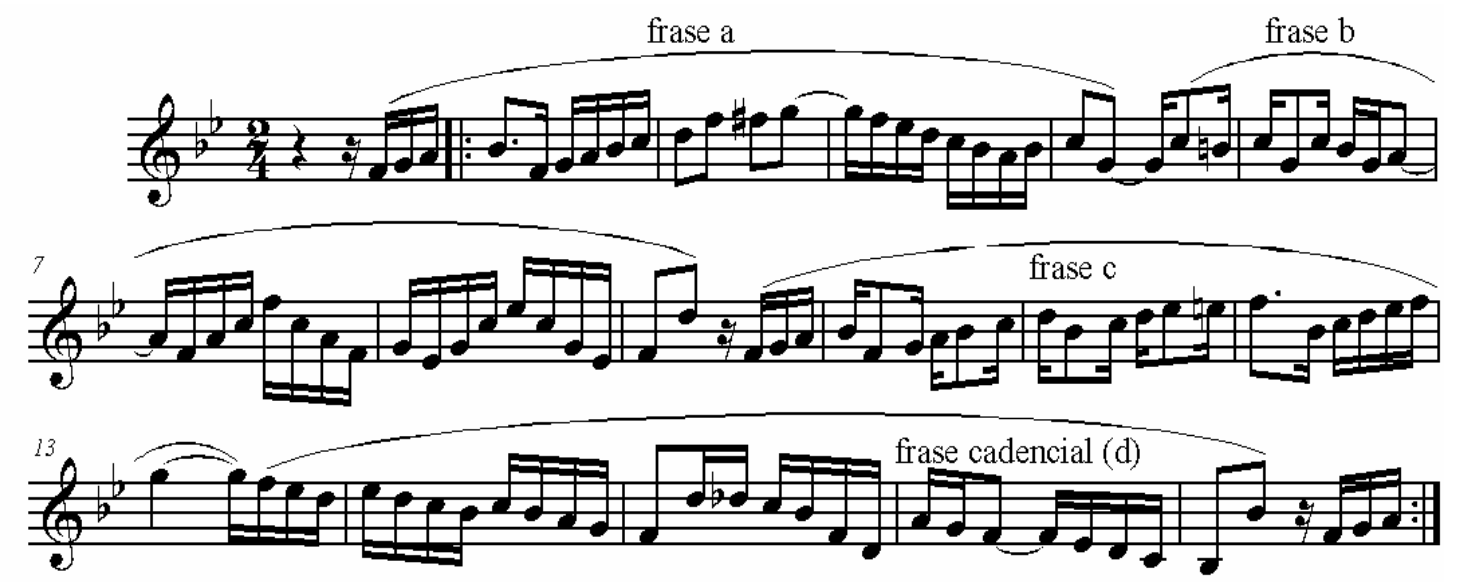

Fig.2.1 Freio a Óleo: seção A.

\footnotetext{
${ }^{36}$ Songbook de Frevos. Recife: Secretaria de Cultura e Turismo, 1998.
} 
Alguns pesquisadores já apontaram para tal paralelo entre a fraseologia musical e a versificação poética, nesse caso, na tradição musical ioruba do Benin.

Se a anáfora é vista como a reiteração de vocábulo em posição de dominância sintática, poderíamos nós reescrever esta definição em termos musicais, no que concerne aos termos /a/ das frases, como a reiteração de uma estrutura em posição de dominância métrica [...] No caso musical, a reiteração de /a/ cria uma inusitada correspondência entre a realização métrica ocidental e a ioruba. (LACERDA, 2001)

A partir das possibilidades apresentadas (estruturas binárias, ternárias e agora incluindo as do verso branco), as canções se estruturaram, como demonstrado na dissertação, em alguns padrões formais como o da Canção de Uma só Parte (A), Formas Binárias (AB) e derivadas (por exemplo: AA') e Ternárias (ABA), sendo o B visto ora como outra estrutura em tonalidade diferente, ora como uma Seção Média Contrastante, e a forma rondó ABACA encontrada nos choros de Pixinguinha. Para todos esses tipos formais foi destacada a importância da forma da gravação ou arranjo, pois é nele que a obra musical se dá do ponto de vista fenomenológico.

Cada peça pôde ser classificada dentro de protótipos preexistentes, ainda que tivessem características próprias e únicas. Surge, então, a questão: como tantas obras se encaixam em padrões característicos quando se tem, pelo menos no caso da música popular estudada, certeza de que os autores não conheciam ou não pensavam em tais padrões? Eles preexistiam na música clássica? Será que a música, quando tonal ${ }^{37}$, aponta inexoravelmente para tais procedimentos?

O musicólogo francês Alain Daniélou (2003) estabeleceu, em seu artigo sobre as origens da música sacra, sete categorias através das quais as diversas formas de música religiosa podem se enquadrar e essas categorias avançam no sentido de uma aproximação com as concepções mais vigentes de música, do ponto de vista do senso comum. Possivelmente o uso de “sinos, gongos, ritmos hipnóticos” pode não ser considerado música pela maioria das pessoas, principalmente ocidentais ${ }^{38}$. Mas as categorias que se sucedem são exatamente

\footnotetext{
${ }^{37}$ Cabe aqui o questionamento do que é tonal. A rigor, dentro de uma concepção Schenkeriana, a música popular estudada (choro e bossa nova) não seria tonal, mas não seria isso um exagero? As melodias não se formam a partir das mesmas escalas da música "culta" tonal, ainda que não haja rigor na condução de vozes e não se atinjam as linhas fundamentais? E aquela música se baseia em cadências harmônicas que, ainda que tenham suas peculiaridades, obedecem, grosso modo, aos padrões cadenciais tradicionais.

38 "In ancient forms of animist religion, (...), the only forms of music with sacred character are those relating to dances and magic rites. Their melodic forms are extremely simplified, whereas their hypnotic rhythms, (...), are extremely complex and highly developed. It is these archaic forms that the rhythms of religious dances probably come, creating states of collective mystic inebriation found in all other religions, the Dionysian mania, the Muslim zekhr, Tantric Hinduism, etc.” (DANIÉLOU, 2003, p.19)
} 
aquelas nas quais o uso do poema “devocional” se faz presente ${ }^{39}$ e, posteriormente, a tradição das recitações de textos sacros, como no Islã e o judaísmo ${ }^{40}$. A essas categorias soma-se também o que ele chama de formas de música modal ${ }^{41}$, estreitamente ligada às anteriores. Como se pode notar, verso, recitação e modalismo encontram-se entrelaçados nessas manifestações. Além disso, tais categorias poderiam mapear o fenômeno musical e modal do universo do Nordeste brasileiro, haja vista a existência das ladainhas e práticas religiosas daquela região, passando para a recitação e improvisação do verso na cantoria, os quais são, em muitos casos, fenômenos modais e poéticos.

Como se busca aqui uma analogia da fraseologia musical com a estrutura poética, é importante que se busque também essa analogia na comparação direta entre os elementos musicais e os elementos poéticos a partir do cotejamento de ambos demonstrados através das análises das próprias obras selecionadas, a fim de se responder às seguintes indagações: teriam uma correlação direta as repetições motívicas e fraseológicas e as rimas das canções selecionadas para esse trabalho? No caso afirmativo, como se daria tal correspondência?

Entretanto, é importante ressaltar que o valor das estruturas poéticas só serão considerados na medida em que influem no fazer musical, ou seja, não interessa o processo de construção da letra em si, mas em que medida ela altera ou deixa de alterar os contornos fraseológicos estudados. Ou seja, trata-se de um trabalho que se dá em um nível neutro, a partir da divisão tripartite da semiologia musical proposta por Jean Jacques Nattiez a partir de J. Molino, em oposição aos níveis poiético - da relação da obra como o autor e seu momento historico - e estésico - da relação da obra com sua recepção.

Para explicar plenamente o funcionamento semiológico de uma obra ou prática musical, é preciso ir além das estruturas imanentes - recorrendo, no dizer de Molino à 'análise do nível neutro' - e considerar as estratégias de criação que originaram tais estruturas (poiéticas) e as estratégias de percepção por elas desencadeadas (estésica). [...] As insufuciências do Estruturalismo, conduziram-me, [...], a adotar o modelo tripartite de Molino. Nesse modelo 'trans-estruturalista', não se trata de esquecer as estruturas, porém de se apoiar nelas ou as integrar em uma perspectiva que as ultrapasse. (NATTIEZ, 2005, p.30-31)

\footnotetext{
39 “A very important aspect of Indian religious music coming from the Shaivite and Dionysian tradition is the 'song of praise' [...]. The 'participants' [...] are the god's devotees, corresponding to the Dionysian bacchants. [...] We find same forces, [...], in the mystic poetry chanted by the Iranians, the Mathnavi in particular.” Ibid, p.20, 21.

40 "The similarities observed between Vedic psalmody and its other forms in the Mediterranean world, including Jewish and Christian psalmodies, do not necessarily imply an influence but common sources.” Ibid, p.24.

41 “[...] modal music has a deep psycho-physiological effect, while mental concentration on the structures of a mode is considered as one of most efficacious forms of meditation. [...] This concept of the modes psychological and ethical influence was common to the whole ancient world, to India, as well Persia and Grecce.” Ibid, p.21.
} 


\subsection{Procedimentos Analíticos Adotados}

É necessário ressaltar que, de maneira geral, evita-se o exesso de informação nas análises por dois motivos: o primeiro é porque elas podem sobrecarregar demais a partitura, às vezes com informações óbvias; em segundo lugar porque o uso das extensões é facultativo, no caso do jazz, ao intérprete. Quer dizer, se um harmonizador escolhe usar a $9^{\text {a }}$ para um acorde dominante, outro pode escolher a $13^{\mathrm{a}}$ e um terceiro, as duas. O importante aqui é saber que se trata de uma tipologia dominante e se cumpre essa função, dependendo do contexto no qual se encontra.

Além disso, o leitor pode consultar a referida dissertação (TINÉ, 2001) para fins de padronização das cadências harmônicas de sentido tonal, juntamente com o conceito de transliteração da cifra, pois foram inseridos na pauta os acordes a fim de obter novos significados.

Richard S Parks, a partir da teoria dos conjuntos de Allen Forte, classifica as escalas para efeito de análise da obra de Claude Debussy como pertencentes basicamente a quatro gêneros que Forte classificou: dois classificados como diatônicos - de cinco (pentatônicos) e de sete sons, gênero de tons inteiros e, por fim o gênero octatônico. Entretanto, por que chamar uma escala por sua classificação em PC 7-35, quando se pode chamar simplesmente de modo lócrio ou escala maior, acepções já consagradas no meio musical? A teoria dos PCs talvez fosse mais bem utilizada em casos de conjuntos que não se enquadrassem em nenhum molde conhecido, como no caso do atonalismo livre, por exemplo. Por outro lado, o pensamento das escalas através dos gêneros, exposto anteriormente, pode conduzir à visão dos modos como subprodutos de uma escala, tal como Kostka (2006) apresenta os modos: como rotações de uma determinada escala, fazendo assim uma diferenciação estratégica desses dois termos (modos x escala). Por exemplo, da escala pentatônica extrair-se-iam cinco modos derivados.

\footnotetext{
"Pentatonic" is a generic term for all five-note scales, but when one refers to the pentatonic scale, $[. .$.$] is usually the one that is meant. Notice that it uses$ only major seconds and minor thirds. Because this version of the pentatonic scale contains no half steps, it is sometimes called the anhemitonic pentatonic scale. [...] Any member of the pentatonic scale can serve as tonic: thus, five "modes", or rotations are available. (KOSTKA, 2006, p.23)
}

Da escala maior podem se extrair sete modos ou rotações, inclusive aquele que corresponde à escala, mas que no contexto modal obedece a outros parâmetros: o modo jônio. 
Modal scales had been largely out of favor with composers since the beginning of the Baroque [...]. But modality was enthusiastically rediscovery by a number of early twentieth-century composers. Though the modal theory of the Renaissance recognized both authentic and plagal modes, the distinction is not important in modern usage. One way to present modes is to notate them using the pitches of the C major scale. (Ibid., p.27)

Aqui os modos plagais poderão ser mencionados quando pertinentes ao material abordado, principalmente do ponto de vista da percepção. Disposições como o $4^{\circ}$ modo da escala menor bachiana (mixolídio $4+$ ou lídio com $7^{\mathrm{a}}$ menor), o $5^{\circ}$ modo da escala menor harmônica (frígio Maior), etc. serão chamadas aqui de modos diatônicos. Entretanto, chamam-se aqui os modos derivados da escala maior de modos diatônicos puros quando não tiverem alterações e diatônicos híbridos quando as tiverem - por exemplo, o citado modo mixolídio com a $4^{\mathrm{a}}$ aumentada.

Por fim, cabe ressaltar que procura-se definir o que é modal com base principalmente no que se percebe como tal e, a partir dessa percepção, procura-se contorná-la terminologicamente da maneira mais apurada possível. Se, como visto, os termos cadência, plagal, dominante foram transpostos de uma realidade melódica para uma teorização da harmonia, por que o mesmo não se daria com o "modalismo”? No entanto, é nessa mesma transposição que o termo Dominante se torna problemático aqui. Ao se tomar o mote D-T ou (t) como o gerador da tonalidade, nota-se que sua adaptação para dominante menor (d) não pode ser tomada como função, pois, se admitida a hipótese da função da dominante menor, admite-se uma cadência sem sensível, quer dizer modal, no seio do tonalismo. Não que ela não possa ocorrer do ponto de vista estilístico, como, aliás, demonstram os exemplos do romantismo tardio, mas ela não pode ser considerada constituinte do fato tonal, o mote D-T. Isso quer dizer que procuro fazer aqui a diferenciação apontada por Schoenberg (2004) entre a função de dominante, caracterizada especificamente pelo acorde maior com $7^{\mathrm{a}}$ menor, da região da dominante, quer dizer, acordes advindos de uma tonalidade subordinada que se relaciona com uma tonalidade principal.

Nesse sentido, a região da dominante menor pode perfeitamente se relacionar com a região da tônica maior ou menor. Essa definição também não significa que o acorde maior com $7^{\mathrm{a}}$ menor sempre exerça a função de dominante, como será exemplificado nas análises.

O compositor Vicentti Persichetti também vê os modos como subprodutos de um conjunto como o da escala maior e outras:

O princípio de construcción modal que produce los siete modos diatônicos (dórico, frigio, etc.) puede aplicarse a qualquier escala, criando multiples 
versiones. La primera versión modal de qualquier escala comienza em la tónica, la segunda em la supertónica, etc. (PERSICHETTI, 1985, p. 42)

Entretanto, apesar de essa visão ser assumida aqui do ponto de vista prático-analítico, o dado que reside por trás de tal concepção deriva da assunção do temperamento igual como referência de afinação. Ou seja, é somente em um sistema de divisão igualitária intervalar que os modos podem ser vistos como subprodutos de uma escala, pois, do contrário, cada um pertenceria a uma afinação própria, como ocorria em outros períodos históricos da música ocidental e na música não ocidental.

Portanto, apesar de a abordagem analítica ser unificada para todos os materiais aqui em foco, não há, de fato, um modalismo único, mas, sim, diferentes tipos de modalismo que diferem de época para época, de sistema de afinações para outros e de manifestações culturais étnicas para outras e transposições delas para universos populares e cultos.

Além disso, há que se diferenciar o hábito funcional dos modos, próximos ao modelo eclesiástico - seja no terreno da improvisação através da associação de escalas com acordes, seja através do uso nas composições -, dos modos como conceito musicológico.

\subsection{Sistemas e Processos Modais}

O verbete mode, do The New Grove Dictionary of Music and Musicians (V.12. p. 775859), traça um panorama histórico desde o sistema gregoriano - passando pelos oito modos e suas diferenciações plagais na ampliação das respectivas tessituras quarta abaixo e pela adaptação para 12 modos no período renascentista, com a inclusão dos modos jônio e eólio até a acepção do final do século XIX do modo, incluindo aqui o lócrio sem as diferenciações plagais para os outros seis, como conceito musicológico ${ }^{42}$. O verbete inclui, a partir de então, abordagens do folclore anglo-americano para daí saltar em abordagens não ocidentais, envolvendo os conceitos de makam, proveniente das manifestações islâmicas, e de raga, para o caso indiano e sul-asiático. Obviamente que a analogia desses termos desde muito é debatida como já o demonstra um artigo do musicólogo Harold Powers, de 1958, comparando os conceitos de modo e raga (POWERS, 1958, p. 448-460). Por fim, o verbete inclui manifestações do Extremo Oriente como os da ilha de Java e Japão.

\footnotetext{
42 "By the mid-18 century, 'mode' in European languages meant a collection of degrees of a scale [...] being governed by a single chief degree: a mode was a scale with a tonic, which was the last note of a melody or the root of final triad.” Mode, SV, 1: Middle East and Ásia. p. 829. Os sistemas modais ocidentais também foram expostos por autores como Zamacois (1993, V.III, p.390-397) e nos anexos de Paz (2002, p.189-192).
} 
Apesar de todas as discrepâncias e distâncias de tais musicalidades, todas foram enquadradas sob a mesma égide, a da música modal, ainda que esta seja uma visão etnocêntrica, ou seja, aquela na qual o olhar parte do Ocidente europeu para as outras culturas, e o termo usado para abranger todo esse território tenha sua origem determinada por aquele olhar. Entretanto, não seria a percepção da recepção ocidental que faz acreditar terem essas manifestações algo em comum?

Invoca-se aqui, para buscar sair de tais dilemas terminológicos, o conceito do estudo sincrônico da linguagem. Este conceito, derivado do estudo da lingüística em contraposição à abordagem diacrônica, pocura descrever os elementos e propriedades de uma determinada língua a partir de um recorte temporal específico, independentemente de fatores históricos anteriores ou de conseqüências posteriores ao momento recortado.

By the synchronic study of a language is meant the description of a particular 'state' of that language (at some 'point' in time). It is important to realize that sinchronic description is not restricted in principle to the analysis of modern spoken language. [...] The principle of the priority of synchronic description, [...] implies that historical considerations are irrelevant to the investigation of particular temporal 'states' of a language. [...] It is the task of synchronic linguistic description to formulate these systematic 'rules' as they operate in the language at a particular time [...] synchronic analysis is independent of such knowlegde of the history of the language as may exist in speech-community. (LYONS, 1968. p. 46, 48, 49)

Apesar disso, são necessárias algumas considerações e contextualizações mínimas, como as que se seguem.

\subsubsection{A Concepção de Modo no Contexto Medieval e Fora do Ocidente}

O citado musicólogo, que também foi músico e se dedicou à execução da vina ${ }^{43}$, Alain Daniélou utiliza os termos modo e raga como sinônimos, tendo como base, principalmente, o modelo grego de construção dos modos.

Hindu music belongs to the same music group as Greek music and ancient Turkish music, which became Arab music. This music group is known as modal [...]. The belief that the modal form is a development of what is termed melody is harmonic music is a serious mistake. [...] modal music only appears to be melodic from the point of view of simultaneous harmony. From the point of view of its own expression, it is quite different. To

\footnotetext{
${ }^{43}$ Instrumento indiano.
} 
perceive modal music however, we must forget all our musical habits and acquire new ones. (DANIÉLOU, 2003, p.108)

Há também o dado que parece ter passado despercebido por muitos estudiosos: o do temperamento igual. Se a nota dominante no canto gregoriano do modo frígio era do e não si, possivelmente por questões de entonação, pode-se especular no quanto mudou com o passar dos anos a percepção dos modos quando eles passaram a ser "igualmente temperados". Segundo J. Javier Goldaráz Gainza, o principal sistema de afinação ligado à época do cantochão era o pitagórico, ainda que pudesse haver uma dissociação entre conduta teórica e prática, derivadas de concepções platônicas e boecianas ${ }^{44}$.

Esta división platonica de la octava, la 'escala del Timeo', [...] habitualmente se conece como 'afinación pitagórica' de la escala diatónica. Hay que se observar en ella que las terceras mayores, compuestas de dos tonos mayores, son muy grandes [...], lo que las hace muy aptas para la música melódica e monófona pero inservibles em la polifonia. [...] Esta seria la división de la octava típica de toda la Edad Media hasta la llegada del Renascimento. (GAINZA, 1992, p. 21)

Parece lógico que os “sistemas” modais precedem o temperamento ${ }^{45}$. No importante texto sobre música turca escrito por Rauf Yekta Bey, em 1922, para a enciclopédia musical do Conservatório de Paris, o autor aborda o quanto soa estranho para os ouvidos orientais suas próprias músicas executadas em bandolins ou pianos, quer dizer, por instrumentos igualmente temperados. Por outro lado, ele também enfatiza que o oriental também não toca microtons como se fossem semitons; como o ouvinte ocidental ingenuamente imagina, tais diferenças se dão mais como ajustes de afinação dentre de escalas setenárias! ${ }^{46} \mathrm{E}$, nesse mesmo texto, Yekta Bey defende a idéia de que a música turca, e para ele, portanto, árabe, a regência de tais microtons se dá baseada na mesma afinação pitagórica, que teria sido mantida pelos árabes e persas desde a Antiguidade.

De cela, nous pouvons conclure que la musique qui, seulement dans les siècles derniers a èté baptisée orientale, en Europe, est née dés la plus haute antiquité chez les Aryans de la Perse, et que, de là, elle s’est répandue dans

\footnotetext{
44 “Ao falar de música Boécio entende uma ciência matemática das leis musicais; o músico é o teórico, o conhecedor das regras matemáticas que governam o mundo sonoro, enquanto o executante é apenas um escravo sim perícia e o compositor é um instintivo que não conhece as belezas inefáveis que só a teoria pode revelar.[...] Boécio parece quase felicitar Pitágoras por ter empreendido um estudo da música relicto aurium judicio, prescindindo do juízo do ouvido [...]. Trata-se de um vício teoricista que caracterizará todos os teóricos musicais da Idade Média.” ECO, Umberto. Arte e Beleza na Estética Medieval. Rio de Janeiro: Ed. Globo, 1989.

${ }^{45}$ Ver as considerações de GALLOP apud PAZ, 2002, p.21.

${ }^{46}$ YEKTA BEY, R. La Musique Turque, EMDC, I/v. (1922), 2945-3064.
} 
les siècles suivants chez les principaux peoples; elle a été l'objet, pour la première fois, d'etudes théoriques chez les philosophes grecs comme Pythagore et ses successeurs, et à ce moment seulement elle a pris la forme d’une science; c'est la théorie de cette science musicale que a été empruntée aux Greecs par les Arabe, ainsi d'ailleurs que d'autres sciences, et en même temps les Arabes recurent beaucoup des Persans au point de vue pratique de cet art. (YEKTA BEY, 1922, p.2953)

Há que se ponderar que não se pretende apresentar uma descrição do sistema árabe em geral, mas o do musicólogo em questão, principalmente pela descrição minuciosa dos intervalos microtonais, todos rigorosamente definidos dentro de padrões pitagóricos:

Les détails précédents on fait voir que la gamme fondamentale de l'Orient contient trois sortes d'intervalles: $1^{\circ}$ Le ton majeur, qui est représenté par 8/9; $2^{\circ}$ Le ton mineur, qui est représenté par le $9 / 10$, cependant, je répète que ce 9/10 est la valeur approximative du ton mineur employé dans la musique orientale. La valeur juste est 59049/65539; parce que le ton mineur de la musique orientale est composé de deux limma. Par consèquent: 243/256 x 243/256 = 59049/65539; $3^{\circ}$ Le demi-ton majeur qui est représenté par 15/16; cependant, ce 15/16 est lui aussi le valeur approximative du demiton majeur. Le valeur juste em est 2048/2187, et on lui donne le nom d'apoteme. (Ibid., p. 2949)

Esses números são bastante conhecidos da afinação pitagórica ${ }^{47}$; o que causa espanto é o seu aparecimento em um contexto, num primeiro momento tão diverso. Gainza (1992) definiu tal afinação como pitagórica de terços de tom em 17 partes, embora a acepção "terço de tom” tenha sido refutada por Yekta Bey.

Será que o mesmo não aconteceria em relação aos srutis hindus ${ }^{48}$ ? Parece que não, muito embora outros números ligados às afinações anteriores ao igual temperamento aparecerão. Novamente não se está aqui a descrever os microtons da música indiana, mas apresentando essas a partir do musicólogo Alain Daniélou. Um dado muito relevante é que, de toda divisão da oitava apresentada pelo autor em The Raga's of Northern Indian Music (1980), nenhuma das notas coincide com as do temperamento igual.

By trying all the possible combinations of the minor tone (10/9), the major tone, and the major half tone(16/15) and the all intervals resulting from their sums or differences, we find that the minor half tone (25/24) is the difference between the minor tone (10/9) and the major half tone (16/15), the limma

\footnotetext{
47 “Com o descenso até as razões de 9:8 (o tom inteiro) que, juntamente com o resto subsistente do leîmma, preenchem todos os intervalos de 4:3 (os tetracordes), Platão atinge a plenitude do setenário, a base da escala diatônica na música modal e tonal, a estrutura subjacente a todos os modos.” (RIZEK, 2003, p.98)

48 "Since the remotest times, Hindu music uses a set of intervals defined by simple musical ratios. This has led to a division of the octave into a scale of 66 notes, of which 22, corresponding to the simplest numerical ratios, [...]. Naturally, such intervals are not and cannot be equal.” (DANIÉLOU, 2003, p. 114)
} 
(256/243) is approximately equal to the difference between the major tone $(9 / 8)$ and major half tone (16/15), the maximum tone (8/7) is approximately equal to the difference between the ditone (two majors tones) and the minor tone and so forth. We thereby obtain a division of the major tone into nine intervals, the minor into eight and the diatonic (major) half tone into five. These intervals are each of one comma (81/80 = 5 savarts). (DANIÉLOU, 1995, p.21)

Embora o autor defina tais números como aproximados, eles não deixam de corresponder aos números da chamada afinação natural ou justa, também chamada de sintônico-diatônica ${ }^{49}$, que passaria a figurar no Ocidente a partir do período renacentista. Em ambos os casos (turco e indiano) encontram-se autores que não concordam com tais descrições dos microtons, como Kaufmann (1985), por exemplo. Este baseia sua convicção no convívio com os músicos práticos e dá aos srutis um sentido mais ligado à performance, variando de um intérprete para outro.

Entretanto, as dez principais ragas do Norte da Índia são apresentadas por ambos autores os, Daniélou e Kaufmann. Fez-se aqui uma correspondência com a nomenclatura adotada nesta tese: I Kalyana (4º modo diatônico puro - Lídio); II Bilaval (1º modo diatônico puro - jônio); III Khammaju ( $5^{\circ}$ modo diatônico puro); IV Bhairava ( $3^{\circ}$ modo diatônico híbrido $-5^{\circ}$ modo da escala menor harmônica); V Bhairavi ( $3^{\circ}$ modo diatônico puro); VI Yavanapuri ( $6^{\circ}$ modo diatônico puro); VII Todi ( $3^{\circ}$ modo diatônico híbrido - escala octatônica sem $4^{\text {a }}$ diminuta); VIII Shri ( $3^{\circ}$ modo diatônico híbrido - escala octatônica sem $3^{\text {a }}$ menor); IX Marava ( $4^{\mathrm{o}}$ modo diatônico híbrido - Lídio com $2^{\mathrm{a}}$ menor); X Kafi (2 ${ }^{\mathrm{o}}$ modo diatônico puro). A figura a seguir apresenta os modos correspondentes:

\footnotetext{
49 “[...] assentada no senário, a crise é amplificada, pois, por sobre a incomensurabilidade já dada das potências de 3 e 2, temos agora, pela extrapolação do âmbito quaternário para o do senário, a inserção das potências de 5 [...], incomensuráveis com ambas anteriores, o que significa que as novas razões superparticulares advindas de tal extrapolação, 5:4 (a terça maior) e 6:5 (a terça menor), são incomensuráveis com as quintas (3:2) e com as quartas (4:3), e, obviamente, com as oitavas.” (RIZEK, 2003, p.103)
} 

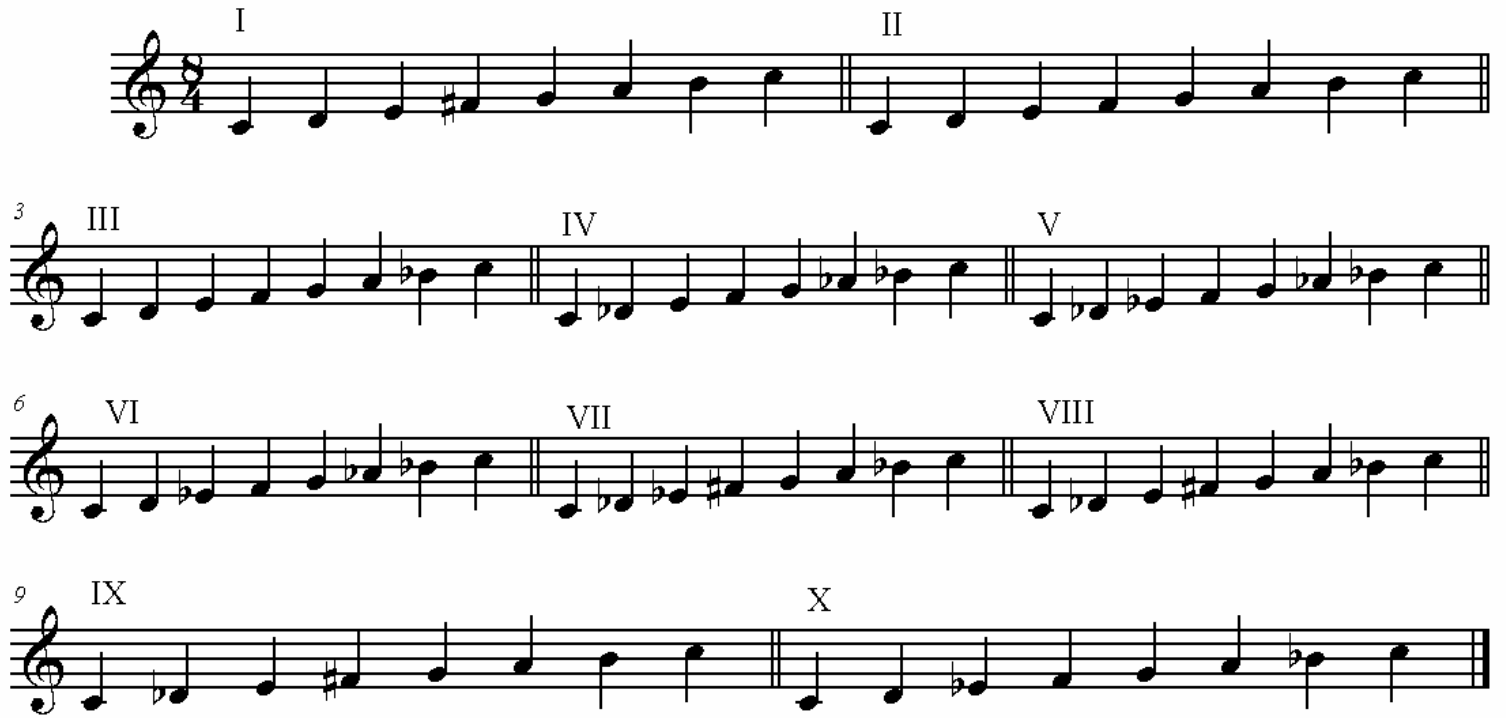

Fig.2.2 Ragas do Norte da Índia

Nota-se que o nomear aqui aplicado nas ragas baseadas na escala octatônica é completamente artificial, haja vista que, por ser considerada uma escala simétrica, tal simetria é derivada do sistema do igual temperamento, o que não é o caso aqui. Outras considerações sobre tais simetrias serão expostas adiante.

No sistema da música carnática do Sul da Índia, há uma série de 72 "Melakarta Ragas”, cujo perfil se assemelha bastante ao dos modos eclesiásticos, desconsiderando as ragas com notas cromáticas e com intervalos próximos da $2^{\mathrm{a}}$ aumentada do sistema do igual temperamento, construídas em análise combinatória a partir de tetracordes com a $1^{\mathrm{a}}$ nota de cada tetracorde fixa, a $4^{\text {a }}$ do primeiro tetracorde com apenas uma mobilidade e as demais livres: todas sempre com sete notas em uma base de doze sons!

Raga can be succinctly defined as a pattern formed out of swaras (tones), whereby all or some of the seven swaras are combined in various ways during ascending $[\ldots]$ and descent [...]. Ragas are innumerable in number and variety, but they can be classified according the whether they are sampura [completas], varja [incompletas] or vakra [irregulares]. [...] Within the compass of sampura ragas fall 72 vital and rich melakarta ragas known as janaka, mela, karta or parent ragas. These are fundamental ragas, forming the basis for the creation of innumerable other ragas, known as janya ragas. [...] The salient features of the melakarta ragas are given below: a) They have all seven notes [...] in both arohana [ascendente] and avorahana [descendente]; b) the tones appear in their regular sequence; c) the individual tones used in the avorahana and arohana are of the same kind. [...] Seventytwo melakarta_ragas are formed by grouping seven notes . [...] in different combinations. The melakarta ragas are divided into two groups of thirty-six each, the first set inclusive of MA1[fá] [...] and the next set inclusive of 
MA2 [fa\#] [...]. The tones SA [do] and PA [sol] are common to all ragas. (KANTHIMATHI; STACKHOUSE, 1987, p. 11, 12, 14)

Daniélou considera tal classificação um tanto artificial, argumentando que nem todas essas ragas são utilizadas na prática, preferindo, portanto, o sistema do Norte da Índia.

\subsubsection{A Concepção de Modo Medieval e Renacentista}

Durante o período renascentista, a percepção dos modos começa a se enfraquecer, pelo menos aos ouvidos contemporâneos, com a introdução de alterações nas seções cadenciais de cada modo e de acordes formados pela soma das consonâncias.

Com o desenvolvimento da polifonia outros acidentes surgiram, denominando-se esta prática música ficta, ou 'música falsa'. Esta conotação deve-se ao fato desses acidentes não serem inseridos na partitura, mas subentendidos e executados na prática. Além do si bemol, usava-se fá sustenido, dó sustenido e sol sustenido, principalmente nas cadências [...]. O uso excessivo de acidentes destrói o caráter dos modos. (CARVALHO, 2000, p.44)

Mesmo quando se tratava do modo frígio, sua terça (naturalmente menor) era elevada cromaticamente, transformando o último acorde em maior, soando como uma espécie de semicadência, ou frase interrogativa ${ }^{50}$. Nesse período há a preferência pela afinação justa ou sintônico-diatônica, devido à capacidade desta de abrigar acordes que vinham se formando através da soma das consonâncias.

Las vantajas de la justa entonación sobre la pitagórica estriban em uma maior simplicidad de sus razones, amén de que se corresponden com la teoria física proveniente de los armónicos, es decir, sons naturales. (GAINZA, 1992, p.40)

Entretanto, segundo Rizek (2003, p. 108), “se as potências de 2 (oitavas pares) e de 3 (as quintas e quartas ímpares) já se mostravam inconciliáveis [...], a inserção do número primo 5 (as terças maiores e menores) - [...] - aprofunda a incomensurabilidade”. Isso acarretava diferentes intervalos dentro do próprio âmbito da gama escalar, quer dizer, tinha-

\footnotetext{
50 "The unusual position of the semitone, does not require an unusual cadence and on this account the regular cadence cannot be employed. Concerning the use of the third in the final chord you should have no misgivings, because what I told you regarding the omission of the third holds true only in cases in which it is possible. You have rightly recognized that one cannot use the fifth resulting, and that because of this, one must take a major third instead; for the minor third being a more perfect consonance is still less suitable for the end.” (FUX, 1965).
} 
se, por exemplo, um tom expresso pela fração 9/8 e outro em 10/9. Para se igualar tais diferenças que se davam em toda a escala, uma série de temperamentos chamados de mesotônicos foram propostos durante todo o período do Renascimento até o século XX, mesmo após a adoção mais generalizada do temperamento igual. Segundo Zamacois (1994) e Chogga (1517-1590), entre outros, além de defender o uso da justa afinação, também incorpora, a partir de Henricus Glareanus (1488-1563), aos quatro modos gregorianos os hoje conhecidos jônio e eólio, estranhos ao mundo medieval, dando ao jônio a posição até hoje associada à escala de $d o$.

The earliest designation (9th century) for the modes was derived from the names protus, deuterus, tritus, and tretardus [...] given to the four basic finalis: protus authenticus [...], protus plagius [...], deuterus authenticus [...], deuterus plagius [...], etc. [...] Another terminology rarely employed in the Middle Ages but commonly used today, borrows its names from ancient Greek theory: the four authentic modes are called Dorian, Phrygian, Lydian, and Mixolydian; the prefix hypo- is employed for the plagal modes (Hypodorian, etc.). To these names Glareanus added Aeolian (for a) and Ionian (for c'). [...] In modern writings the twelve-mode system is sometimes enlarged to one of fourteen by addition of the Locrian and Hypolocrian, based on the tone b as the final. [...] Zarlino, in his Istitutioni Harmoniche of 1558, adopted Glareanus' system of twelve modus but placed Ionian and Hypoionian first, so that the series began with the two modes on c - an early indication of the growing awareness of the importance of the "major mode.” (Havard Dictionary of Music, 1974, p. 165-167)

A partir do contexto descrito, segundo Gainza, a prática da música ficta levou à necessidade do temperamento igual, na medida em que as fórmulas cadenciais eram transpostas para os diferentes modos.

La necesidad del temperamento igual se hace ya evidente em el siglo XVI en consecuencia de las inovaciones de la música ficta; el aumento del número de alteraciones y la división de toda la octava em semitonos hacia necessaria uma reforma de la afinación. (GAINZA, 1992, p.115)

Entretanto, para se chegar ao temperamento igual, segundo o autor, foi necessário o uso da álgebra através de um instrumento chamado mesolábio. 
Para hallar matematicamente quintas, tonos, partes de comma, etc., mesotónicos, es insuficiente el uso de la aritimética. Hallar um medio, um quarto, um tercio o um séptimo de comma equivale a hallar la raiz quadrada, quarta, cúbica o séptima de 81/80, lo qual da cantidades irracionales. Es possible, no obstante, determinar estas cantidades algebricamente. [...] Zarlino y Salinas recurrirán a um procedimento arquimediano para hallar más de uma media proporcional entre los términos de uma razón superparticular, consistente em el uso del mesolabio. (GAINZA, 1992, p.84, 85)

\subsubsection{A Concepção de Modo no Romantismo Tardio}

Ao pensar a polifonia desse período como modal com cadências tonais, as citadas características do Nacionalismo Romântico dos compositores periféricos podem ser pensadas como tonais com cadências modais. E, nesse sentido, houve novas modificações das teorias modais na medida em que, agora, estão subordinadas à "tirania” dos acordes e do temperamento igual. Como exemplos de tais procedimentos podem-se citar: o tema do $2^{\circ}$ movimento do Quarteto Americano Op.96 de Anton Dvorak no modo de ré menor sem sensível (eólio ou dórico), o segundo tema do $3^{\circ}$ movimento da Sonata $N^{\circ} 3$ de Edward Grieg no modo de mi dórico (transposto para lá na reexposição) e as cadências plagais, movimentos fracos (segundo Schoenberg de $3^{\mathrm{a}} \mathrm{S}$ ascendentes e $4^{\mathrm{a}} \mathrm{s}$ descendentes) e acordes sem terças da peça “A Grande Porta de Kiev”, integrante da obra Quadros de uma Exposição de Petrovich Mussorgsky ${ }^{51}$, dentre uma infinidade de outros, como aqueles apontados por Piston (1987) e Zamacois (1994) em suas respectivas obras sobre harmonia ${ }^{52}$.

\subsubsection{A Concepção de Modo no Âmbito Étnico-Popular Brasileiro}

A obra de Paz (2002) sobre o modalismo na música brasileira traz em seu $4^{\circ}$ anexo especulações sobre as origens do modalismo no Brasil segundo diversos autores. Influências ibéricas, africanas, mouriscas, gregorianas e indígenas são apontadas. Cabe lembrar aqui, em primeiro lugar, o natural “destemperamento” do canto, principalmente em situações étnicas.

We might add that to sing without accompaniment the tempered scale is an undertaking beyond human capacities, because we cannot, without strong external help, scape from harmonic intervals which alone are in accordance with the physical nature of sounds and consequently with the shapes and

\footnotetext{
${ }^{51}$ Ver Dvorak (s.d.), Grieg (1938) e Mussorgsky (1948). Análises anexas.

52 Concerto para Piano e Orquestra op.16, de Grieg, $9^{a}$ Sinfonia, de Dvorak, Canções Gregas, de Ravel, e Cantos Russos, de Korsakov.
} 
possibilities of the organs by which we can emit and perceive them. (DANIELOU, 1995, 24)

É possível que os cantos destemperados do Nordeste brasileiro tenham passado pelo mesmo processo de adaptação ao temperamento igual, quando tocados por instrumentos de tais características ou harmonizados em peças eruditas durante o modernismo nacionalista do início do século XX. Mesmo assim, algumas das mencionadas priorizações ocorrem principalmente do $5^{\circ}$ modo, como será demonstrado a seguir. Uma das possíveis origens do modalismo nordestino se dá na especulação do elemento mourisco, advinda da dominação do Sul da Espanha e Portugal, na Idade Média. Segundo Bey (1922), a gama natural da música árabe se dá com o deslocamento do último semitom da escala diatônica, que se dá entre a $7^{\text {a }} \mathrm{e}$ a $8^{\mathrm{a}}$ nota, para a $6^{\mathrm{a}}$ e $7^{\mathrm{a}}$, perfazendo, assim, o $5^{\circ}$ modo diatônico simples chamado por nós de mixolídio.

La verité, c'est que la division de l'octave est strictement la mème chez les Arabes, chez les Turcs, chez les Persans, en un mot, partout oú on entend la musique orientale. [...] tous les théoriciens orientaoux parlent d'une seule gamme comme base du système oriental [...] En outre, si, dans la gamme fondamentale de l'Orient, le 1er demi-ton se place entre les 3e e 4e notes, [...] - le 2e demi-ton n'est pas entre les 7e et 8e, mais au contraire se trouve placé entre les 6e et 7e notes de la gamme. (BEY, 1922, p.2948)

Para o autor esta seria também a gama natural grega antiga, atribuindo a Guido Arezzo uma errônea associação ao que chamou de gamme de la minuer sans sensible ao chamado “sistema perfeito” grego que, segundo Bey (1922, p.2958, 2959) seria, na verdade, análogo à gamme de la majeur sens sensible, ou seja, ao modo de sol. De qualquer forma, não deixa de ser significativo que esta gama corresponda a um modo que, sem ser igualmente temperado em sua manifestação étnica, será muito característico nas manifestações étnicas do Nordeste, como se verá a seguir. Além desse dado que corrobora para a hipótese da assimilação moura, há a prática do zajal, um desafio poético recitativo semelhante à Cantoria nordestina hoje popular no Líbano, que também tem origem Ibérica.

\subsubsection{A Concepção de Modo no Século XX}

O Impressionismo no início do século XX fará um uso harmônico dos modos em um sentido mais livre, quer dizer, entendendo aqui por harmônico toda sobreposição vertical, independentemente de se formar acordes baseados em consonâncias e por sobreposição de 
intervalos de terça. Na música de Debussy surgem sobreposições por quartas ou agregados de segunda (clusters), sempre ligadas a uma escala.

Modality is often cited as an important feature of Debussy's music, and certainly one encounters many passages flavored by orderings of diatonic pitch materials that are evocative of Dorian or Phrygian rather than minor, and Lydian and Mixolydian rather than major. (PARKS, 1989, p.42)

É somente a partir de 1870 que, segundo Gainza (1992), o temperamento igual será completamente adotado no Ocidente. É, portanto, somente então que podem surgir as chamadas escalas simétricas na música de Claude Debussy e de Igor Stravinsky. É fundamental perceber que tais escalas têm sempre, por eixo de tal simetria, o intervalo do trítono, que é a base da afinação do temperamento igual.

[... ] la octacva se divide em 12 semitonos, 6 tonos, 3 terceras mayores, 4 terceras menores, etc. Los intervalos correspondem a partes de la escala: tono, $6 \sqrt{ } 2$; tono, $3 \sqrt{ } 2$; tercera mayor, $4 \sqrt{ } 2$; tercera menor, etc. (GAINZA, 1992, p. 113)

A expressão $\sqrt{ } 2$, portanto, representa o trítono, a divisão da oitava em duas partes iguais. $^{53}$ Esse intervalo perpassa todos os chamados modos de transposição limitada de Olivier Messian ${ }^{54}$ - que abrangem a escala de tons inteiros e a octatônica - ou todas as relações entre as notas das séries dodecafônicas que formam, a partir da sétima nota, um espelho intervalar (retrógrado) das seis primeiras (ver Fig. 2.3e). Parece então que somente os modos de transposição limitada seriam os verdadeiros modos do igual temperamento, e sua presença é notável no sistema de base do material utilizado por alguns dos principais compositores do início do século XX. A linha pontilhada da figura a seguir mostra o referido intervalo do trítono.

\footnotetext{
53 “[...] a diagonal do quadrado de um [...] é o símbolo geométrico dessa mesma realidade: confrontada com a singeleza da medida dos lados, 1 , a diagonal é incomensurável; ela é $a$ incomensurabilidade, a raiz quadrada de 2, o trítono!” (RIZEK, 2003, p.115)

${ }^{54}$ Ghezzo, Marta A. Solfège, Ear Training, Rhythm, Dictation, and Music Theory - A Comprehensive Course. Tuscaloosa/ London: The University of Alabama Press, 2a ed., 1993.
} 
10 modo
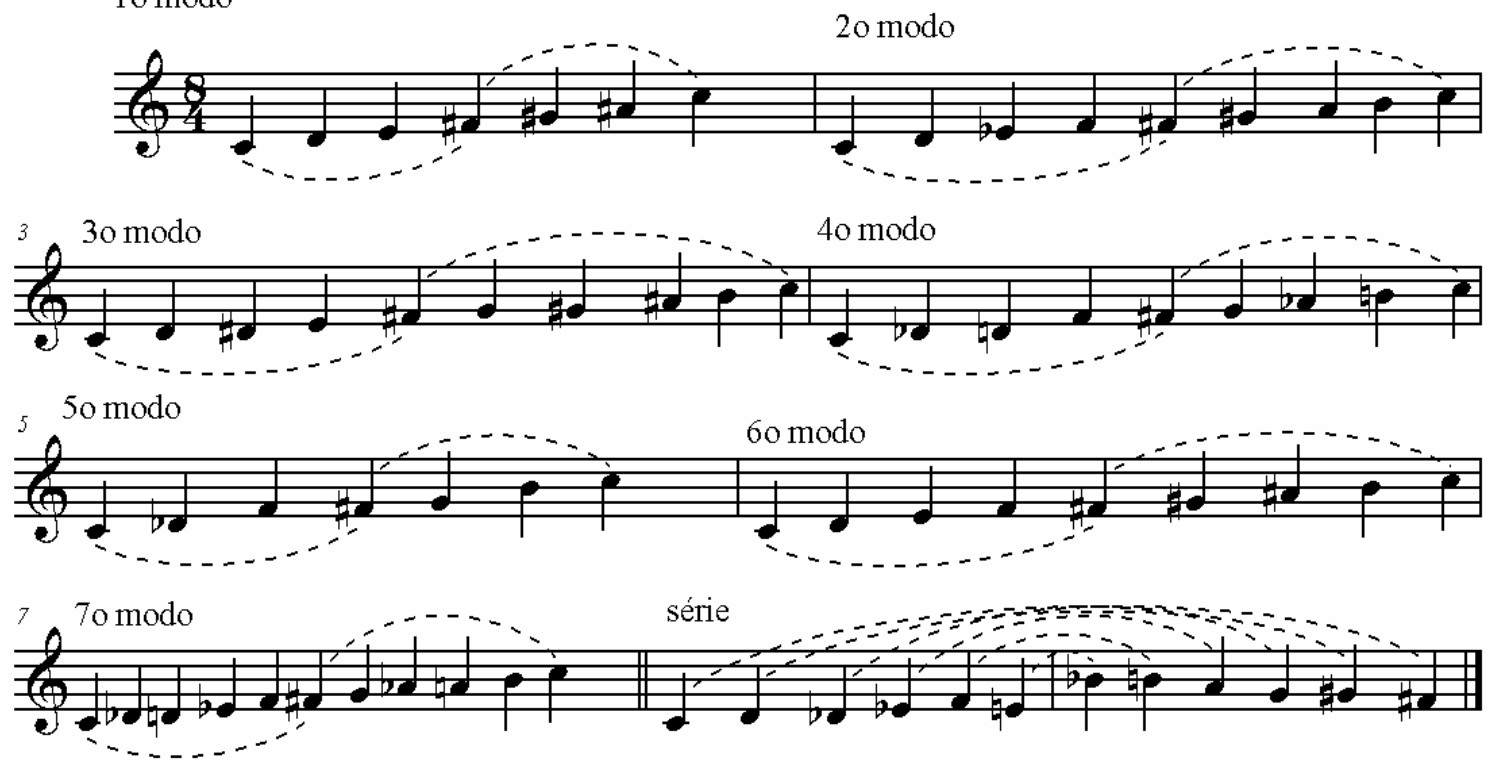

Fig.2.3 "Materiais do século XX - modos de Messian e Série Simétrica - pautados pelo trítono»55

Entretanto, através do recurso da improvisação, o jazz trará um novo uso dos modos que talvez remonte, em alguns expoentes, à música tradicional do Oriente, como também Bártok e Debussy o fizeram no terreno da música escrita.

Without any doubt, the first breach in the edifice of imperial harmony come from Africa trough the intermediary of jazz. By the tonality of its wind instruments, the lively quality of its rhythms and the nature of its improvisations, jazz brought entirely new elements to western music [...] when jazz began to adopt modal structures that had nothing to do with classical tonality, very few musicians perceived that this was a complete change of both system and code of reference. (Daniélou, 2003, p.64-65)

Há, aqui, uma aparente contradição no discurso a favor do modalismo no jazz na medida em que os instrumentos utilizados nesse gênero estão afinados no temperamento igual. Entretanto, através do uso dos bends e das blue notes, percebe-se que este temperamento não é absoluto e, em todo o caso, mesmo nas diversas adaptações modais para o igual temperamento, há que se lembrar que a ressonância dos harmônicos, mesmo em uma harmonia tonal, não é igualmente temperada, quando se trata de instrumentos acústicos.

\footnotetext{
${ }^{55}$ A figura aqui proposta da série espelhada pautada pelo intervalo de trítono foi sugerida em aula pelo professor Ricardo Rizek.
} 


\subsubsection{O Modalismo no Jazz}

A partir do período do Cool Jazz (década de 1950), principalmente através do trompetista norte-americano Miles Davis, o improvisador passou a pensar mais em escalas na improvisação jazzística do que nas mudanças (changes) de acordes, característica da improvisação do período anterior (Be Bop), possivelmente devido à saturação dos procedimentos melódicos e harmônicos ligados a esse estilo marcadamente tonal. Há também, tanto no Be Bop quanto no estilo $\mathrm{Cool}$, uma atitude estética que nega, por um lado, os procedimentos musicais anteriores. Tais fatos fizeram com que paralelamente se começasse a esboçar uma teoria modal da improvisação no jazz e, ao mesmo tempo, houve uma rotulação dessa produção de Miles desse período de Modal Jazz. Hoje em dia, após uma sistematização no ensino de improvisação jazzística, os métodos claramente definem quais modos o estudante deve usar em determinadas situações.

Um dos primeiros músicos que tentou teorizar um sistema para explicar os procedimentos harmônicos e a escolha das escalas no jazz foi o teórico e músico George Russel:

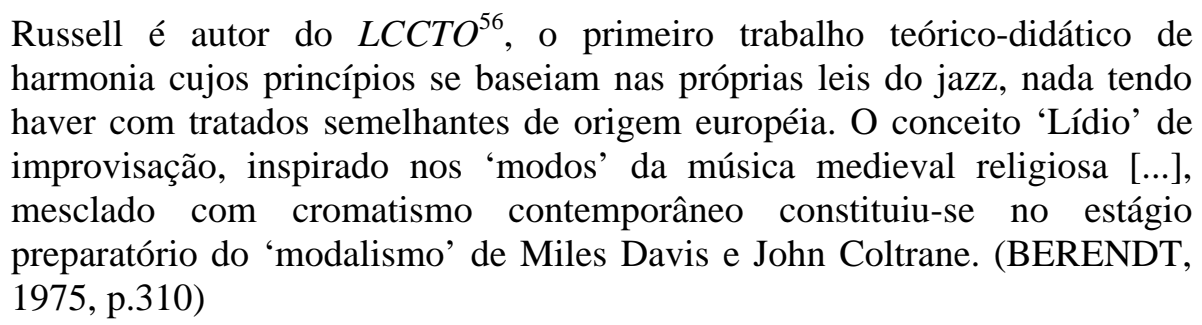

Nessa obra, o autor refere que o músico de jazz deve converter uma cifra (símbolo de um acorde) em uma escala, e chama esse processo de "Polimodalidade Vertical”. Quando isso acontece, o acorde se converte em sua escala-mãe, que se trata da sua escala "Lídio Cromática” (RUSSEL, 1959, p.10). Em oposição a esse procedimento, o autor refere o da “Polimodalidade Horizontal”, na qual se impõe uma simples escala Lídio Cromática para toda uma seqüência de acordes como escalas maiores e blues (Ibid., p.28). Tais procedimentos terminam por derivar em quatro possibilidades - o autor da presente tese entende que são três - de abordagens para a improvisação jazzística:

\footnotetext{
${ }^{56}$ RUSSELL, George. The Lydian Chromatic Concept of Tonal Organization for Improvisation. New York: Concept Publishing Company, 1959.
} 
1. In going vertical melodies ${ }^{57}$ : escalas ou modos que correspondem a cada acorde verticalmente, ou seja, uma para cada acorde;

2. In going horizontal melodies, escalas ou modos que correspondem a toda uma seqüência de acordes, ou seja, uma para todo um centro tonal;

3. Out going vertical melodies (Ibid., p.23): quando é aplicada uma escala Lídio Cromática para cada acorde;

4. Out going horizontal melodies: quando uma escala Lídio Cromática é aplicada a toda uma seqüência de acordes.

Ora, sendo a escala Lídio Cromática na verdade a escala cromática chamada aqui de Lídio por razões de outra ordem (explicar-se-á a seguir): não faz diferença, do ponto de vista da percepção, aplicar uma escala cromática a partir da fundamental de cada acorde ou a partir da fundamental do centro tonal derivado de uma seqüência deles. Por isso, os passos 3 e 4 poderiam se fundir num só. George Russel aponta, como exemplos de tais procedimentos improvisadores, Coleman Hawkins para o primeiro, Lester Young para o segundo, Ornette Coleman e John Coltrane para os últimos.

O autor considera ainda que o modo Lídio é aquele que melhor convém a um acorde maior com sétima maior e passa, então, a considerá-lo o centro gravitacional do conjunto diatônico para, assim, considerar a escala cromática "Lídio Cromática”, na medida em que o centro é o modo Lídio. Chama o modo dórico de Lídio Menor, o modo do $4^{\circ}$ grau da escala maior harmônica de Lídio Diminuto e o modo do $3^{\circ}$ grau da escala bachiana (menor melódica ascendente) de Lídio Aumentado. A partir disso, relaciona sempre um modo "Lídio” para cada acorde.

Se, por um lado, tal sistematização soa bastante arbitrária e incorreta, pois, se tivermos uma cadência II-V-I, mesmo que se aplique de maneira dissociada - na medida em que o grau do modo (IV) não corresponde ao grau da função (I) - um modo lídio ao I grau, do ponto de vista harmônico o centro tonal continua a ser o chamado modo jônio da escala diatônica, pois ele foi precedido por um acorde de tipologia e função de dominante (V). Dessa forma, ainda que se crie, a partir da associação de escalas com acordes, um procedimento “modal”, este não torna a música modal em sentido pleno, ou seja, ele não altera o fio condutor mor da tonalidade, a relação dominante-tônica (D-T) e derivadas entre os acordes. Por outro lado, tal associação do modo Lídio apontava para aquilo que veio a se formalizar com a sistematização

\footnotetext{
${ }^{57}$ O conceito de in going e out going correspondem aos contemporâneos de in side e out side.
} 
das chamadas notas evitadas para cada acorde, isto é, o modo Lídio se encaixava melhor no acorde maior com sétima maior por não ter notas evitadas.

Pelo conceito contemporâneo, o acorde (e seu símbolo a cifra) não só reúnem as notas que o caracterizam, chamadas de notas do acorde [...], mas outras também que o enriquecem, chamadas de notas de tensão [...]. Finalmente a escala de um acorde também pode incluir notas que devem ser evitadas [...] na formação vertical do acorde, mas podem ser usadas em caráter passageiro na linha melódica. (GUEST, 1996, p. 46)

No sentido da ampliação do leque de modos utilizados pelo improvisador, há o incremento dos dois primeiros “modos de transposição limitada”, para usar os termos de Messian. No entanto, se tais modos tiveram largo uso em Bártok, Stravinsky e Debussy, por exemplo, sua aplicação difere completamente do jazz. Enquanto os compositores da primeira metade do século XX usavam tais escalas para se afastarem do tonalismo, propondo uma escuta não direcional e particularizada, os jazzistas os aplicavam exatamente nos acordes dominantes, forçando-os a um direcionamento na relação D-T.

Segue, no subitem abaixo, uma descrição pormenorizada do procedimento harmônico na era do Jazz Modal.

\subsection{A Harmonia e o Improviso no Jazz Modal}

A partir do uso dos modos na improvisação jazzística, Miles Davis passou a escrever temas que propositadamente evitavam a relação D-T por um lado e, por outro, saturavam os acordes de extensões derivadas dos modos diatônicos, primeiramente puros e, posteriormente, híbridos. Por exemplo, o tema intitulado So What, que figura no álbum antológico Kind of Blue do mesmo autor. Gravado em 1958, é um marco na história do jazz, pois as estruturas tonais do estilo Be Bop são abandonadas em favor de uma abordagem chamada de Jazz Modal.

A partir dos meados dos anos 50, a espinha dorsal da evolução do combo é o "Miles Davis Quintet". Além disso, Miles se revelou como o maior descobridor de talentos de todos os tempos [...]. A partir do nosso princípio seletor de combos, um novo elemento passa a ser de importância essencial: o "modalismo", introduzido no jazz por Miles Davis e John Coltrane. O elemento integrador passa a ser a escala e não mais a sucessão de acordes. (BERENDT, 1975, p.310) 
Constituída de apenas dois acordes, trata-se de um AABA de oito compassos cada parte, sendo que a harmonia da seção A só tem um acorde: Dm7 (ré menor com $7^{\mathrm{a}}$ menor). $\mathrm{E}$, na seção $\mathrm{B}$, o mesmo acorde é deslocado meio-tom acima. Isto não significa que o harmonizador esteja preso às notas básicas desses acordes $\left(\mathrm{T}, 3^{\mathrm{a}}, 5^{\mathrm{a}}\right.$ e $\left.7^{\mathrm{a}}\right)$. Qualquer nota do $2^{\mathrm{o}}$ modo diatônico puro (dórico) de cada acorde pode figurar na harmonia em sobreposições de 3as, 4as, clusters diatônicos ou aberturas mistas derivadas das possibilidades anteriores.

A partir de So What, parece ter sido irresistível ao jazzista construir estruturas harmônicas baseadas nesses acordes "modalmente saturados" sem que houvesse, necessariamente, relações de causa e efeito entre eles, como, por exemplo, eles pertencerem ao mesmo campo harmônico ou serem precedidos por acordes de função dominante.

Algumas versões do tema Mayden Voyage ${ }^{58}$, do pianista Herbie Hancock (1965), apontam apenas uma tipologia harmônica para os quatro acordes da música: o acorde com tônica, $4^{\mathrm{a}}$ justa, $7^{\mathrm{a}}$ menor e $9^{\mathrm{a}}$ maior, o assim chamado sus no jargão jazzístico. A princípio todos os acordes teriam como base o $5^{\circ}$ modo da escala diatônica pura (mixolídio); entretanto, exatamente naquele em que há divergências, há uma correspondência com o $2^{\circ}$ modo da escala (dórico). Algumas edições apontam um acorde menor com $6^{\mathrm{a}}$ para tal posição. No caso do sus é importante salientar que aqui ele não cumpre função cadencial, tal como o pesquisador Paulo Sérgio Ribeiro de Freitas apontou, ao meu ver acertadamente, como o representante do I6/4 dentro do contexto da música popular ${ }^{59}$. Outra interpretação do acorde "sus”, dá-se a partir da sobreposição de quartas ou daquilo que viria a se chamar harmonia “quartal”, que também foi uma característica importante do jazz nos 1960. Ele é uma entidade em si, um pouco à maneira impressionista de se utilizar essas tipologias (arquétipos, segundo o compositor Florivaldo Menezes). Também em forma AABA de oito compassos cada um, o chorus $^{60}$ desloca a tipologia em três transposições. Entretanto, o centro (“pan-modal”?) parece estar em ré. As fundamentais dos acordes realizam uma bordadura em torno da nota: ré - fá mib - reb(do\#) - ré. Resumindo, a estrutura harmônica é a seguinte:

\footnotetext{
${ }^{58}$ Outro clássico álbum homônio da historia do jazz e dos anos 1960. Herbie fez parte da $2^{\mathrm{a}}$ formação do Miles Davis Quintet, e esse álbum temático apresenta a viagem imaginária de uma embarcação marítima desde sua inauguração até a dança dos golfinhos (Dolphin Dance) passando por turbulências.

59 “O acorde sobre o V grau diatônico com sétima menor e quarta é aqui denominado V7sus4 e entendido como uma variação estilística do acorde tipo X7 [...]. Deste entendimento podemos concluir que o V7sus4 é uma versão do acorde cadencial de Dominante Quarta e Sexta; sem a sexta e com a sétima. De fato, o V7sus4 é uma espécie de atualização da Dominante Quarta e Sexta, a semelhança entre estes dois tipos específicos de variação sobre o V grau é bastante notável.” (FREITAS, 1994, p. 67)

60 "In jazz any statement, or, more particularly, any statement with variations, of a theme. The term is commonly applied to those clear cut forms that consists of a theme, followed by a series of variations on the theme, and a repetition of the theme itsel.f.” (The New Groove Dictionary of Jazz, p.208)
} 
III-

//: Dsus / \% / \% / \% / Fsus / \% / \% / \% ://

II- $\quad$ VII

/ Ebsus / \% / \% / \% / C\#sus / \% / \% /\% /

I III-

/ Dsus / \% / \% / \% / Fsus / \% / \% / \% //

Por último, pode-se citar como extensão máxima desse tipo de abordagem o tema Time Remembered, do pianista Bill Evans, no qual uma grande seqüência é composta utilizando-se apenas das tipologias maior com $7^{\mathrm{a}}$ maior derivada do $4^{\mathrm{o}}$ modo diatônico puro (lídio) e do $2^{\circ}$ modo (dórico) ${ }^{61}$ na década de 1960. Nesse caso é grande a ambigüidade entre o modal e o tonal. Se por um lado os acordes pertencem às duas tipologias expostas e não se relacionam via campo harmônico ou D-T, por outro, a própria expansão harmônica não deixa de se fazer à maneira de uma seqüência tonal, ou seja, o modus operandi da harmonia tonal no jazz é o da extensão seqüencial, na qual a harmonia de Time Remembered ${ }^{62}$ se dá modalmente por emulação de um tema tonal.

Ainda que os acordes não contenham todas as notas dos modos referidos, isso se dá no cotejamento da melodia e arpejos sobrepostos do improviso com a harmonia, freqüentemente passando pelas notas características: a $6^{\mathrm{a}}$ maior do modo dórico e a $4^{\mathrm{a}}$ aumentada do modo lídio. Além disso, essas seriam as escalas que melhor se enquadrariam nesses acordes, por não terem notas evitadas, muito embora nem sempre o improvisador se prenda à teoria da improvisação, aplicando os modos “corretos”. Segue-se uma tentativa de análise harmônica de Time Remembered, que oscila entre os centros de si e $d o^{63}$ :

\footnotetext{
${ }^{61}$ Além de citar, na frase cadencial final, a cadência de Pavane Pour Une Infante Defunte, de Maurice Ravel. Esse tema de Bill Evans aponta uma expansão para diversas regiões distantes em termos de relações entre tonalidades/modalidades; entretanto, são pautadas pelas cadências do tipo D-T e derivadas.

${ }^{62}$ The Real Book. Milwaukee: Hal Leonard Corp., 6. Ed, s/d. p.413.

${ }^{63}$ A análise dos improvisos nesses três temas de jazz modais aqui abordades encontra-se no anexo.
} 
b: I

C:(VII) I IV III VI II $\quad$ V $\quad$ III- VI-

// Bm7 / C7M / F7M / Em7 / Am7 Dm7 / Gm7 / Eb7M / Ab7M /

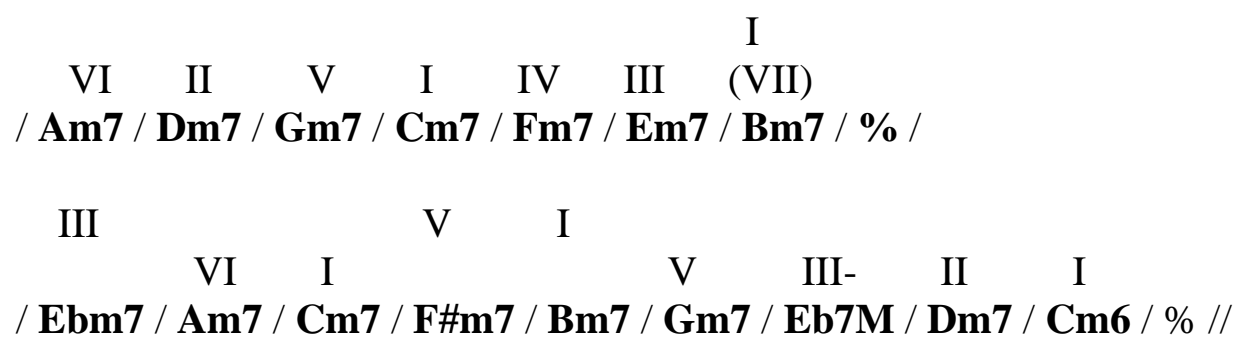

É somente na década seguinte (1970) que há uma modalização mais radical realizando a mencionada verticalização em modos que, originalmente e dentro de certos contextos, possuem notas evitadas ou são híbridos: Miroslav Vitous, Jan Garbarek, Keith Jarrett, Ralph Towner, para citar alguns. Tais autores então ligados à gravadora alemã ECM Records, que promoveu muitos jazzistas europeus sendo que alguns, como os noruegueses Garbarek e Terje Rypdal, estudaram com George Russell. ${ }^{64}$

${ }^{64}$ Ver BERENDT, 1975. 


\section{Busca dos Fundamentos Étnico-Musicais do Repertório Modal da Música Popular}

Na busca dos fundamentos repousados nas manifestações étnicas e folclóricas do repertório apresentado nos capítulos que se seguem, o autor desta tese debruçou-se na audição de uma série de exemplos chamados pela maioria dos músicos populares de "folclóricos". Ouviram-se aproximadamente 500 melodias, das quais muitas foram descartadas ou por não serem modais, ou porque entendeu-se que as características de um determinado gênero já tinham sido exploradas. Primeiramente focou-se em três áreas de apoio em relação aos compositores aqui escolhidos: Nordeste, principalmente de Pernambuco e Paraíba, manifestações afro-brasileiras da Bahia e Minas Gerais, relacionando-se tais áreas com Edu Lobo, no caso pernambucano, Baden com a Bahia e Milton Nascimento com Minas Gerais.

Em relação ao último autor, não se conseguiu encontrar relações claras entre tais manifestações e sua produção no período escolhido como em Congadas mineiras. Selecionaram-se trechos a partir de gravações de Coco (Alegria e Devoção e Zambê - 2000), Maracatu (Nação Estrela Brilhante e Leão Dourado - 2004), Cantoria (Ciclos do Cangaço e Padre Cícero), Catimbó (das Missões Folclóricas de 1938), bem como a coletânea das Missões (Sesc 2006) e o percurso refeito em Responde a Roda Outra Vez (2005). No terreno afro-brasileiro foram ouvidos os álbuns Candomblé da Bahia (1963), Cânticos de Terreiro (1971), Samba, Capoeira e Candomblé (1987), bem como Capoeira- Cordão de Ouro (1975) e Berimbau e Capoeira (s/d). Na área de Minas Gerais não foram encontradas manifestações com as características modais desejadas que, de certa forma, justifiquem parte do modalismo utilizado pelo compositor. Além disso, foram comparados esses exemplos com os do mesmo gênero já transcritos na obra de Mário de Andrade, como será demonstrado adiante.

No tocante às datas das gravações, não foi restringido certo período ou década, como no caso do repertório popular dos próximos capítulos. Isso porque acredita-se que, embora se trate de gêneros dinâmicos, isto é, sujeito às ações das influências dos meios de comunicação de massa (cada dia mais presente em comunidades rurais) e das modificações naturais ocorridas em tradições orais, os gêneros permanecem os mesmos e, em alguns casos, certas canções também permanecem. É o caso da permanência de algumas canções coletadas por Guerra-Peixe na obra Maracatus do Recife (1956) no CD recém-lançado Maracatu Leão Coroado - 140 anos (2005) como em A Bandeira é Brasileira (p. 142, faixa 4), Lanceiro Novo (p. 128, faixa 2), ou ainda do coco Veado lá na Mata, da Missão de Pesquisas Folclóricas de 1938 (SESC: 2006, CD 5 - faixa 6) e no CD Alegria e Devoção (2000, faixa 8) ou a melodia da Nau Catarineta Sua Alteza a quem Deus Guarde, da Missão de 1938 (SESC, 
CD 4, faixa 10) e na reconstituição parcial do trajeto da Missão em Responde a Roda Outra Vez (1998. CD 2, faixa 11).

Todas as transcrições foram realizadas pelo autor e todas trasnpostas de maneira que se retire a armadura de clave. Ou, no caso do catimbó, trata-se de uma revisão a partir do confronto do áudio nos exemplos escolhidos daquelas transcrições realizadas por Álvaro Carlini (1993).

\subsection{Candomblé}

\subsubsection{Canto para Ossaim}

Percorrendo os passos de Baden ${ }^{65}$, partiu-se de uma gravação, a anteriormente citada de Candomblé da Bahia ${ }^{66}$. Através da transcrição e análise do repertório apresentado nesse disco, buscou-se encontrar alguns denominadores comuns com o corpus popular que será analisado.

Ainda que aqui esta seja uma preocupação secundária, o primeiro elemento a ser verificado é o do padrão rítmico. Nas manifestações musicais afro-brasileiras é comum que o executante chame tais padrões de toque, como nos casos do "toque virado" do maracatu, dos toques da capoeira “angola”, “são bento grande” e “são bento pequeno”, ou ainda os toques do candomblé. Normalmente um instrumento metálico como o gonguê ou o agogô é de grande importância para a caracterização desses ritmos; entretanto não se ingressará nesse aspecto de tal música, abordando-se apenas a questão melódica.

\section{Seção A}

A peça apresenta 4 seções (A,B,C e D), antecedidas por uma introdução, definidas pelas repetições das mesmas frases sempre em responsório, do solo masculino pelo coro feminino. Não que se repitam literalmente as frases do solista, mas há a resposta musical. A introdução apresenta as mesmas frases de A, mas os instrumentos de percussão entram aos

\footnotetext{
${ }^{65}$ Baden ouviu os primeiros números de capoeira a partir do disco de Carlos Coqueijo na casa de Vinícius de Moraes, no início da década de 1960.

${ }^{66}$ Candomblé da Bahia: Nação Ketu com Luiz Muriçoca, Continental, LP 1-04-405-332, 1963.
} 
poucos. A seção A se repete seis vezes e é constituída por oito compassos e três frases: uma do solista (dois compassos), e duas do coro (uma de quatro outra de dois compassos).

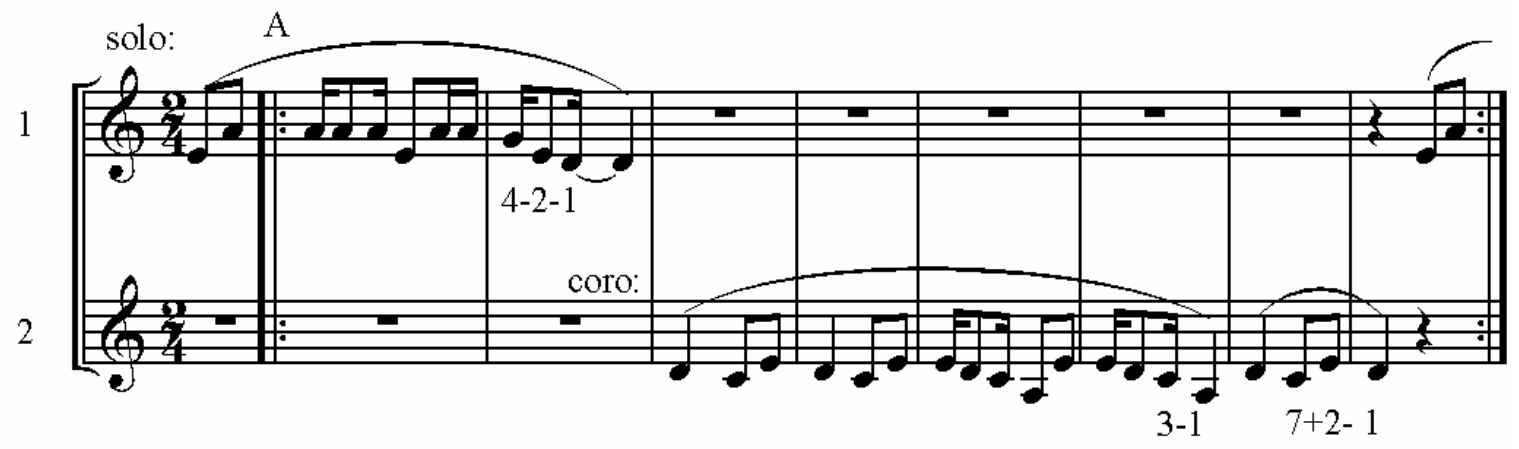

Fig.3.1 Ossaim: seção $\mathrm{A}^{67}$

Como pode-se notar, o material de base melódico é o $2^{\circ}$ modo do gênero diatônicopentatônico anhemitônico, ou seja, se o $1^{\circ}$ modo corresponde às notas $d o$, re, mi, sol e la, o $2^{\circ}$ modo terá exatamente as mesmas notas, porém se iniciando em re, sem intervalos de semitom.

\section{Seção B}

Já a seção B é repetida nove vezes, possui oito compassos e duas frases: a primeira, do solista, com dois compassos em defasagem, pois trata-se de um anacruze e a segunda, resposta do coro, de 6 compassos precedidos por sua anacruze.

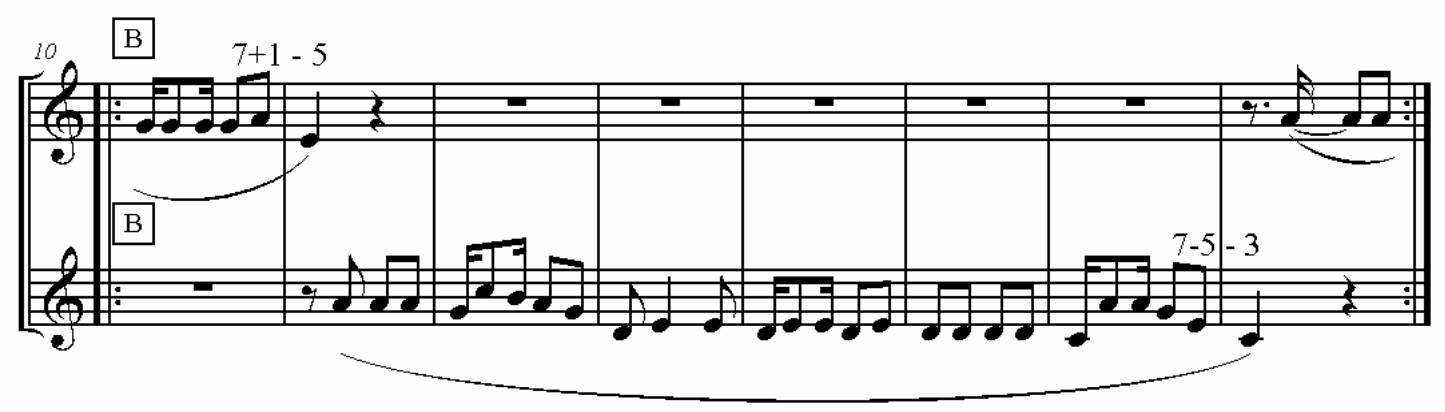

Fig.3.2 Ossaim: seção B

Nesta seção têm-se as resoluções na $5^{\mathrm{a}}$ e na $3^{\mathrm{a}}$ do gênero $5^{\circ}$ modo do gênero pentatônico.

\footnotetext{
${ }^{67} \mathrm{O}$ sinal de + indica um salto ascendente do intervalo, enquanto o sinal de - indica o salto contrário.
} 


\section{Seção C}

Esta seção não apresenta repetições e é constituída por 12 compassos. Trata-se de três frases de dois compassos cantadas pelo solista repetidas, com alterações na terceira ( $e$ ”'). São, portanto, frases derivadas, todas no $2^{\circ}$ modo.
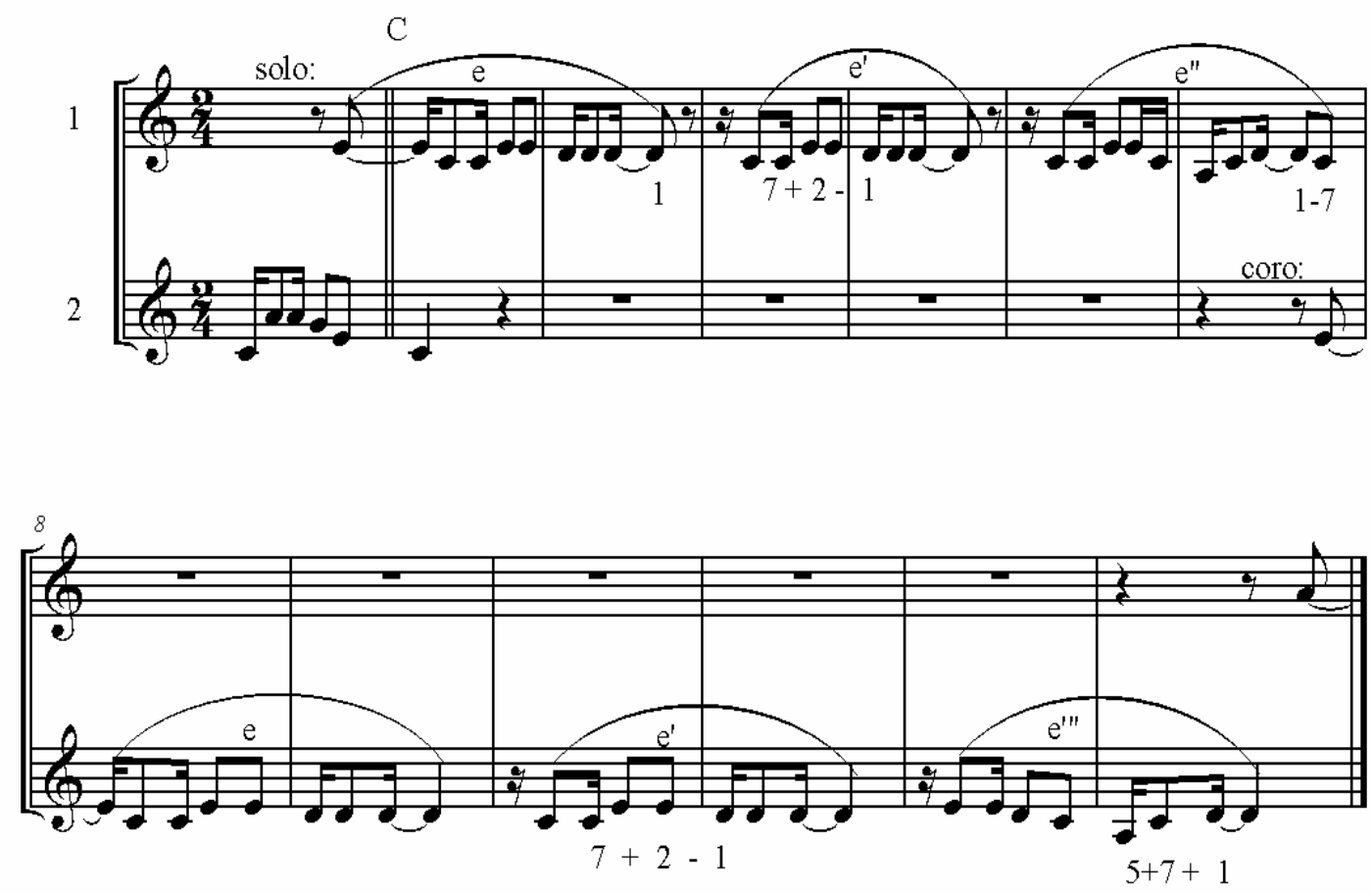

Fig.3.3 Ossaim: seção C

Seção D

Por fim, a última seção, que se repete três vezes, também constituída por 12 compassos com três frases solistas e três de resposta, sendo essas todas derivadas da frase $e$ da seção anterior. 

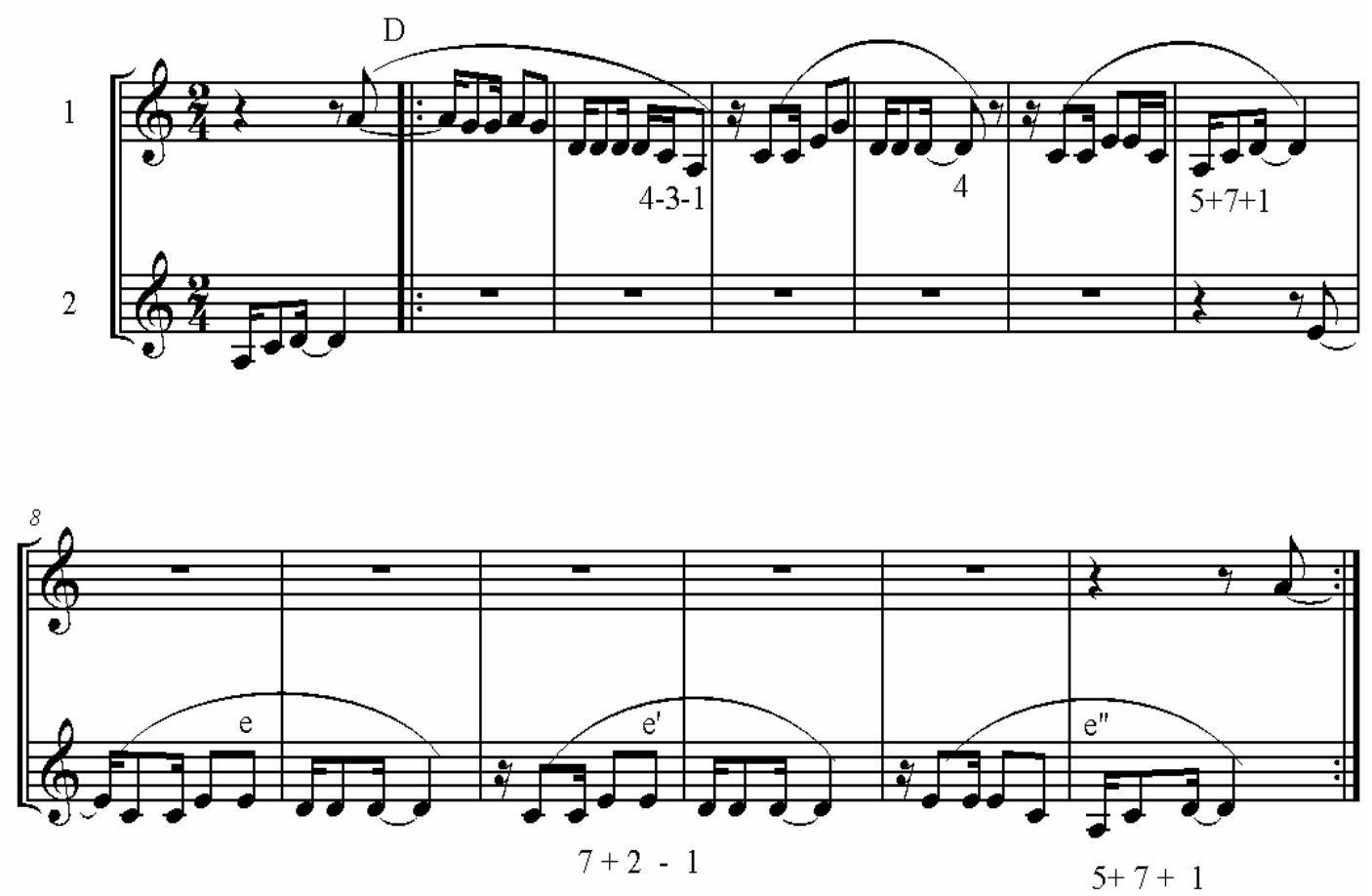

Fig.3.4 Ossaim: seção D

Pode-se especular a respeito de tal priorização no $2^{\circ}$ modo do gênero pentatônico que, além da bordadura mi-do-re, essa nota (rê) encontra-se no eixo simétrico do modo, cercada por dois intervalos de $4^{\mathrm{a}}$ justa (acima e abaixo) e por dois de $2^{\mathrm{a}}$ maior (idem).

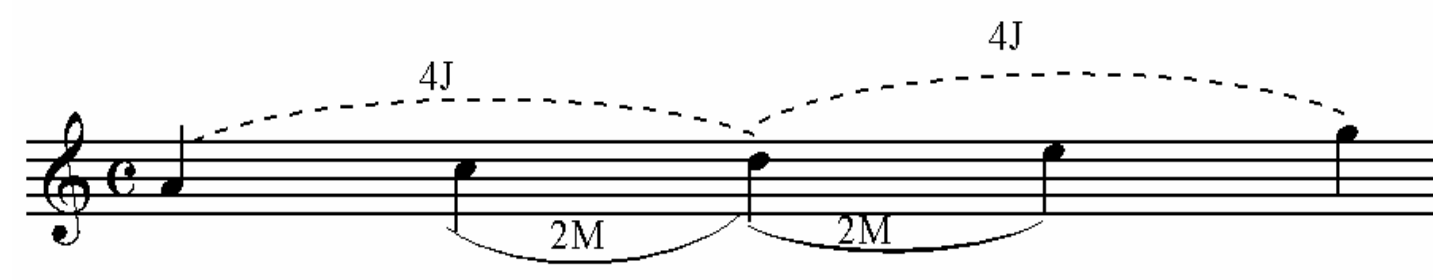

Fig.3.5 - Priorização na $4^{\mathrm{a}}$ nota da escala Pentatônica.

\subsubsection{Canto para Xangô}

Seção A

A escolha do compasso composto para este canto se deu na comparação com outras gravações de pontos dedicados ao mesmo orixá. Há, no total três seções: A, B e C. A primeira, formada por três frases $a, b$ e $c$, repete-se quatro vezes com ligeiras variações a cada repetição. As frases $a$ e $b$ são cantadas pelo solista e duram quatro compassos juntas e a frase 
c dura cinco compassos sozinha. Entretanto, a totalidade das frases que compõem a seção resulta em oito compassos, pois o último compasso da frases $c$ já corresponde ao primeiro de $a$, que é uma frase acéfala. O exemplo a seguir apresenta as frases $a$ e $b$.

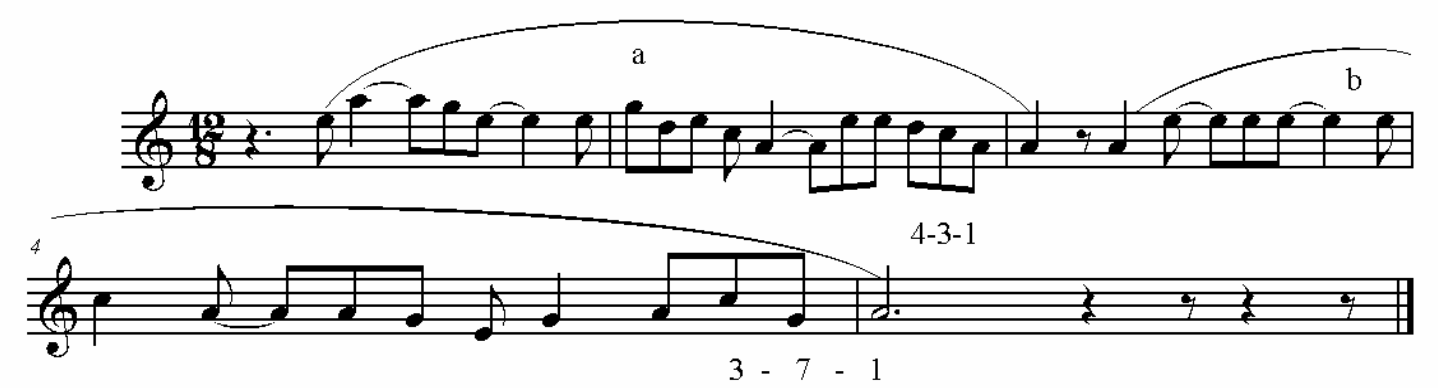

Fig.3.6 - Xangô: frases $a$ e $b$

Todas as frases se resolvem na tônica (1) do $5^{\circ}$ modo do gênero pentatônico, sendo a frase $b$ com o final 3-7+1, tal como a frase $c$ que também é acéfala.

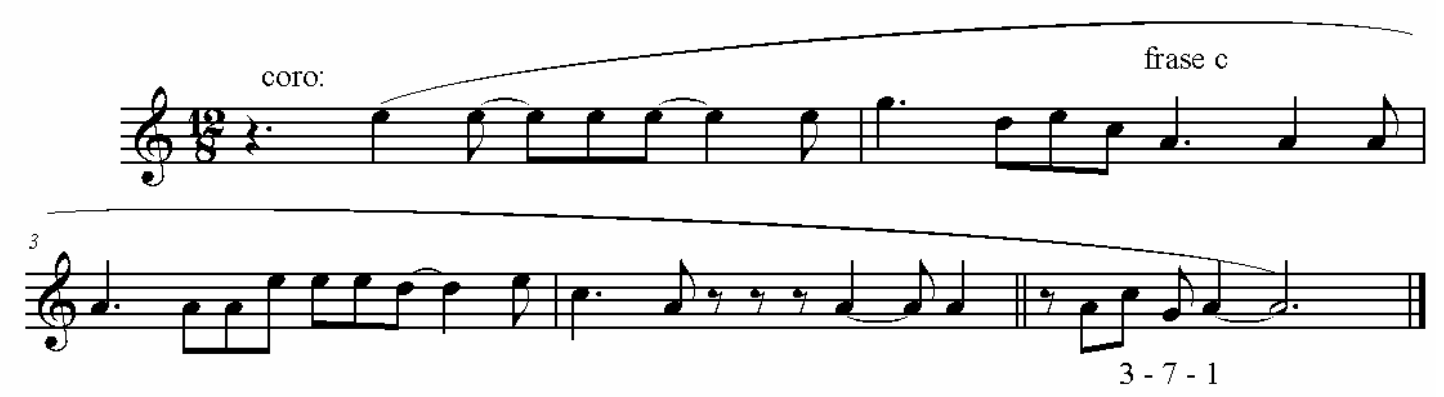

Fig.3.7 - Xangô: frase $c$

\section{Seção B}

A seção B se forma pela repetição - três vezes - das frases $y, x, z$ e w. As frases ocorrem da seguinte maneira: $y-x-y-x-z-w$. Também perfazem um total de oito compassos. $\mathrm{O}$ exemplo a seguir apresenta as frases $y e x$. 


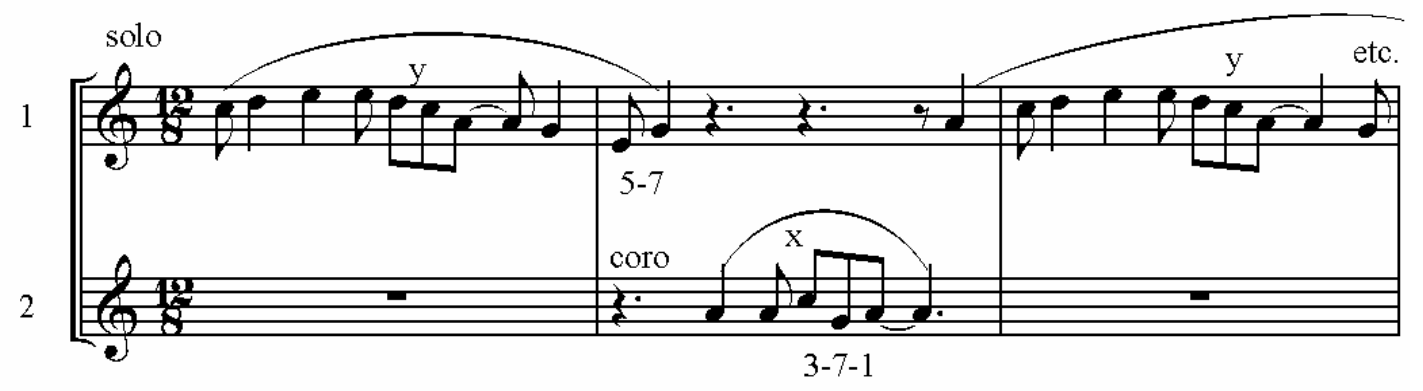

Fig.3.8 - Xangô: frases $y$ e $x$

\section{Seção C}

A última seção, C, repete-se três vezes. É composta por uma frase, $d$, que dura 4 compassos e que é repetida com ligeiras variações ( $\left.d^{\prime}\right)$ pelo coro. Sempre resolve na tônica. Além disso, há a intrusão da $2^{\mathrm{a}}$ da escala menor (si) que não pertence ao gênero pentatônico. O final cadencial da frase também é importante: 5+7+1.

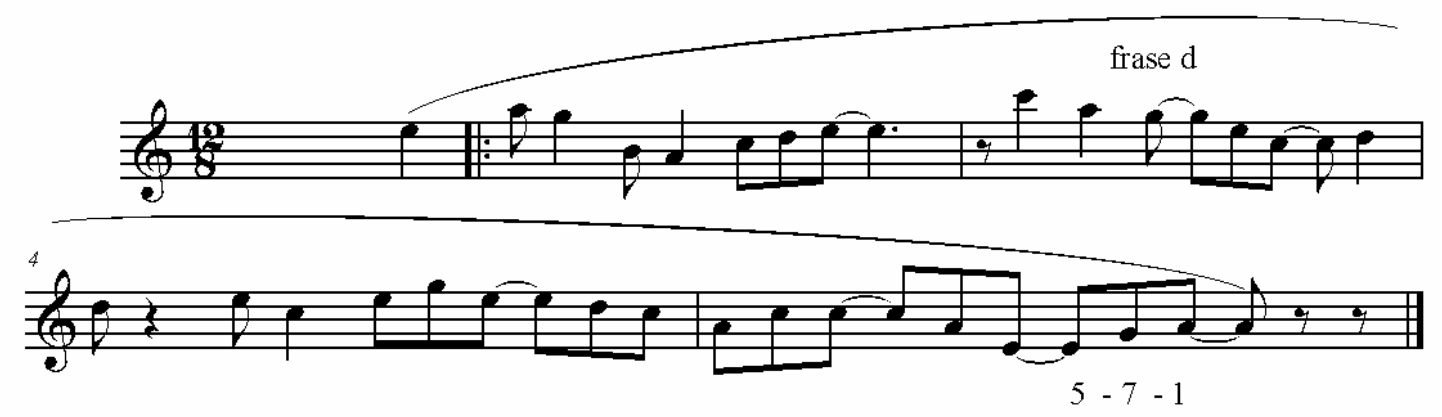

Fig.3.9 - Xangô: frase $d$

\subsubsection{Canto para Yemanjá}

\section{Seção A}

Um dos orixás mais populares, a peça a ela dedicada também oscila entre o 6/8 que parece orientar principalmente o canto e o 12/16 que orienta o toque. Pode-se verificar, posteriormente, se Baden utilizou esses toques ou se fez uma apropriação mais ou menos genérica desse material. $\mathrm{O}$ exemplo seguinte mostra as frases $a$ e $b$ em responsório com os instrumentos rítmicos acima demonstrando a dubiedade rítmica. Essas frases se repetem oito 
vezes, formando a seção A de quatro compassos. Há a predominância do $2^{\circ}$ modo do gênero pentatônico com a nota extra si. A frase $b$ se resolve na $4^{\text {a }}$ nota do respectivo modo.

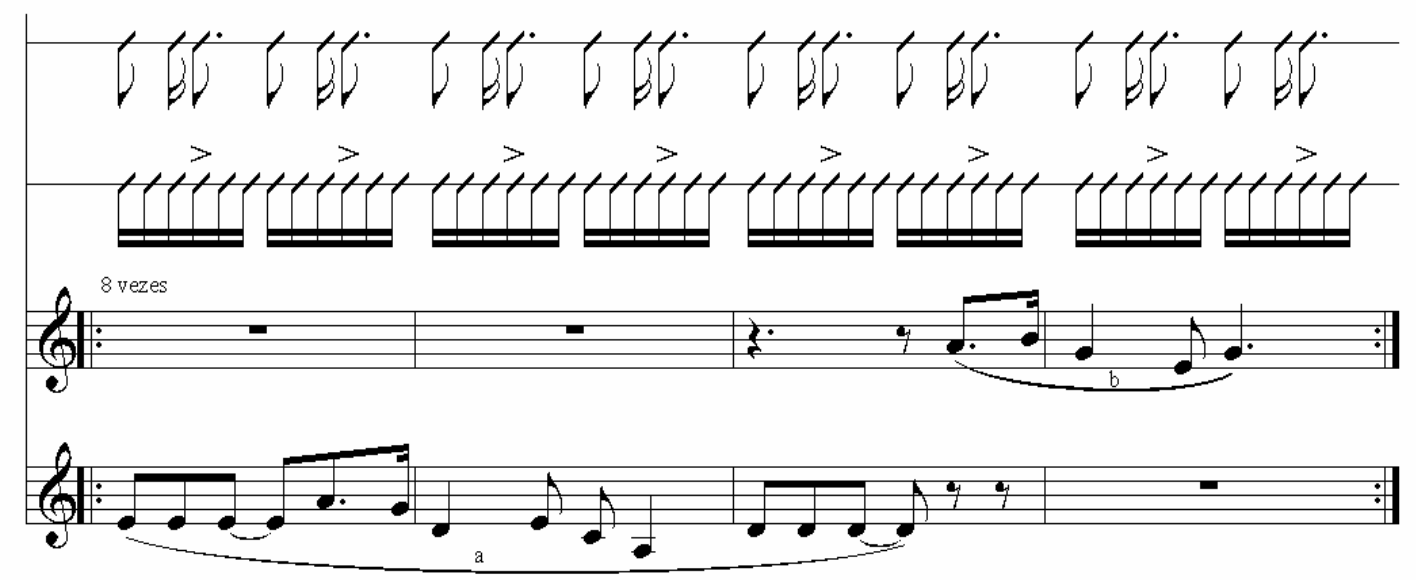

Fig.3.10 - Yemanjá: seção A

Seção B

A seção B é composta por uma frase $c$ de oito compassos que é repetida pelo três vezes coro. Há, naturalmente, um maior número de ornamentações por parte do solista. O material básico é também o $2^{\circ}$ modo do gênero pentatônico. A nota fa\# funciona como uma aproximação cromática da $4^{\mathrm{a}}(\mathrm{sol})$. Novamente os pontos de articulação são a $4^{\mathrm{a}}$ (final da semifrase) e a tônica (1).

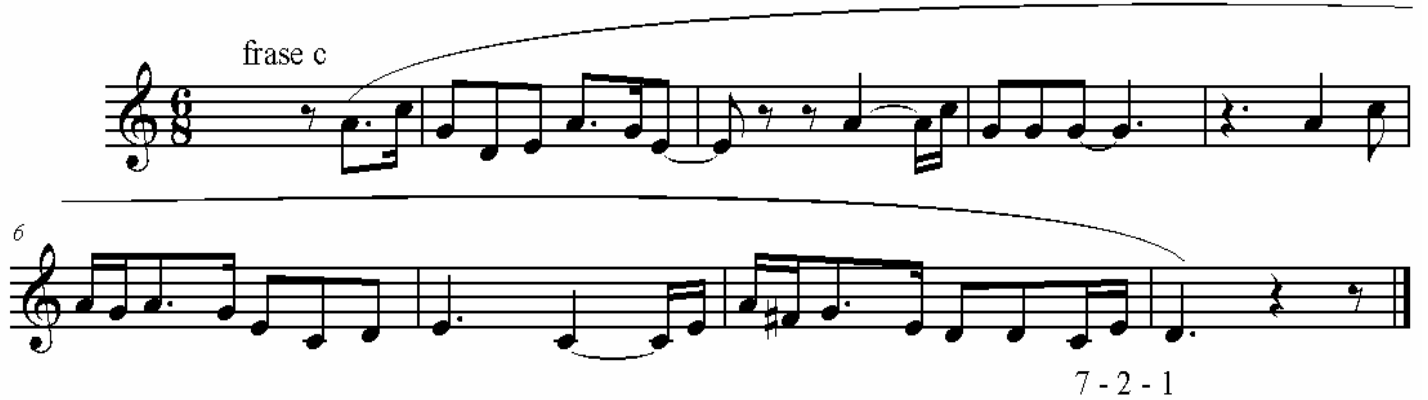

Fig.3.11 - Yemanjá: frase $c$ 


\section{Seção C}

Por último, a seção C retoma as frases curtas da seção A e o responsório de frases diferentes que se repetem seis vezes. O material é pentatônico e há a mesma aproximação da frase anterior. A frase $d$ se resolve na tônica do $5^{\circ}$ modo e a frase $e$ na tônica (1) do $2^{\circ}$ modo.

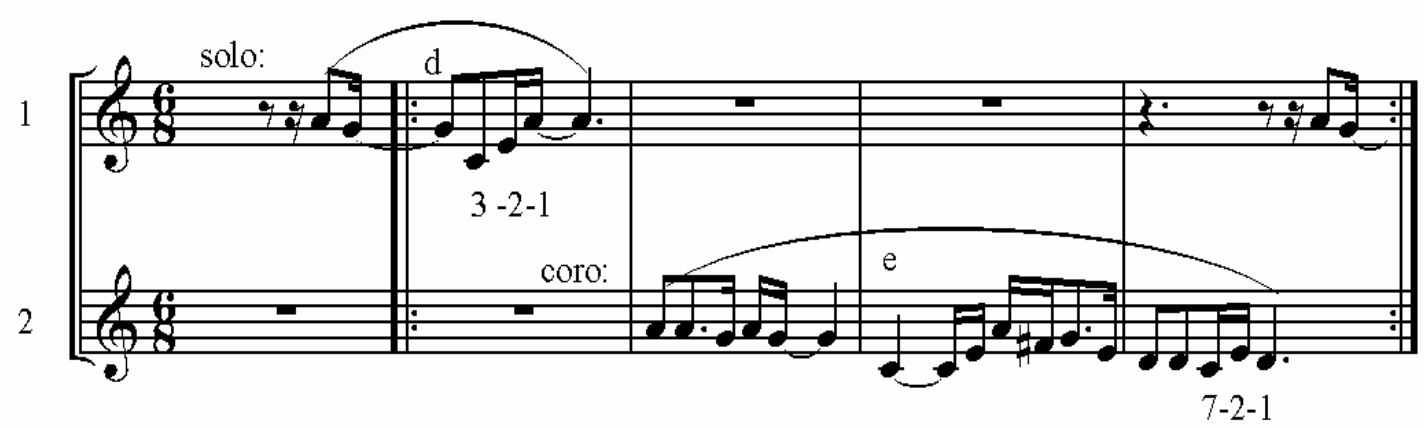

Fig.3.12 - Yemanjá: seção C

\subsection{Capoeira}

\subsubsection{Tava Lá em Casa}

Saindo do gênero devocional do candomblé, passa-se agora ao modo guerreiro dos combates dos capoeiras. A citada gravação de 1975, Capoeira Cordão de Ouro, que foi uma das bases para a dissertação de mestrado de Galm (1997), apresenta em sua décima faixa o cântico Tava Lá em Casa, transcrito na página seguinte.

Com exceção das frases $b$ e $b^{\prime}$, o gênero básico para a construção dessa melodia é o $5^{\circ}$ modo da escala pentatônica. Toda construção fraseológica completa 32 compassos; entretanto, há uma série de irregularidades internas às frases. O final 4-1 apresentados nas frases $a$ e $c$ é o de maior ocorrência e de caráter afirmativo. O final $1+5$ das frases $a$ "' e $e$ tem caráter suspensivo. Há ainda o final $7+1$ na frase $d$. A frase $c$ parece que transpõe a pentatônica para o IV grau realizando o movimento 1+3-1, ou pode-se pensar na inclusão momentânea do 6a nota da escala de lá menor natural (fá). 


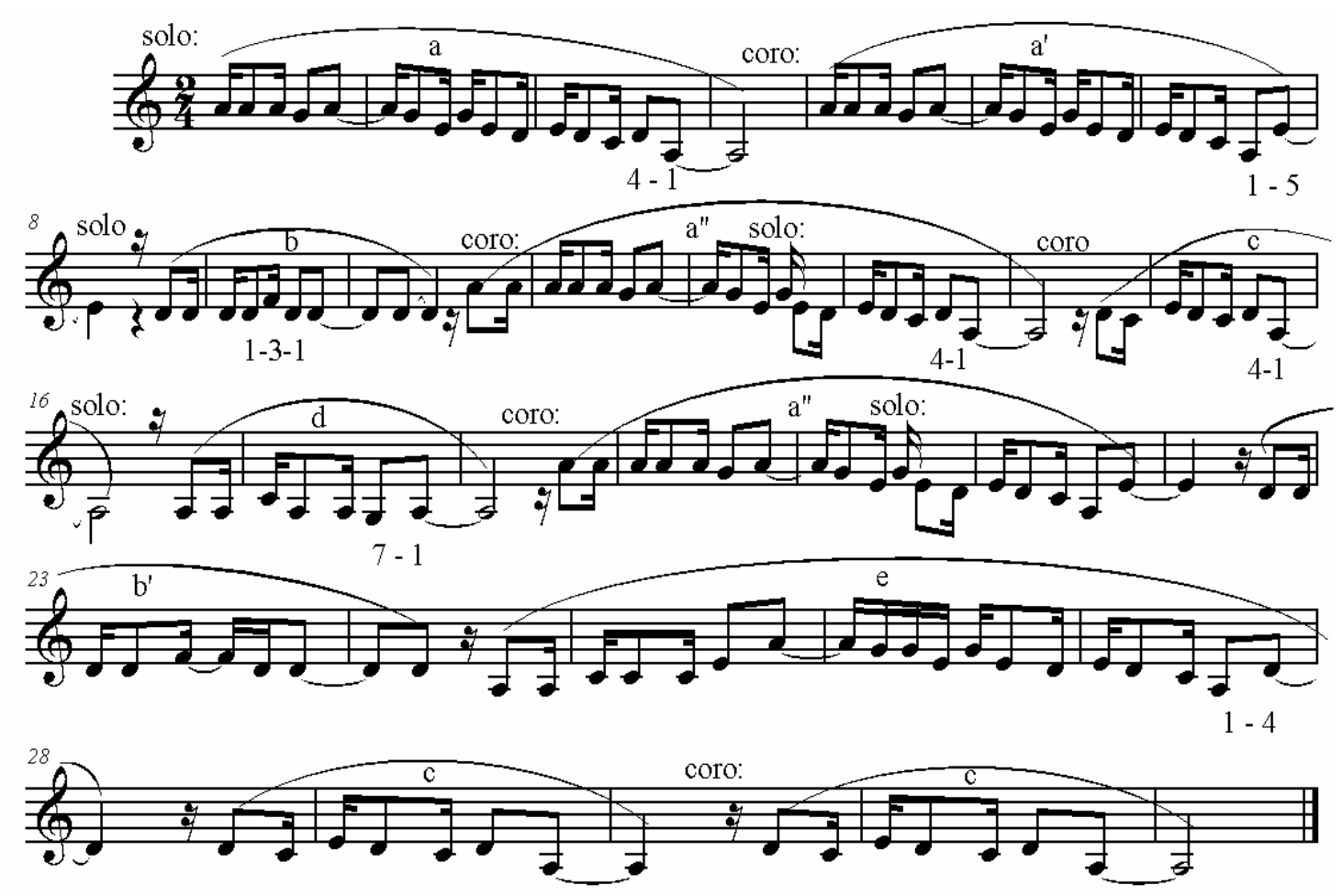

Fig.3.13 - Capoeira: Tava Lá em Casa

\subsubsection{Pisa Caboclo}

Na $12^{\mathrm{a}}$ faixa do mesmo disco, há o canto intitulado Pisa Caboclo, que está baseado no gênero pentatônico ( $1^{\circ}$ modo) nas suas três primeiras frases, a sensível si está excluída, com a inclusão da nota fá, utilizada na frase $b$. Mas é na frase cadencial $b^{, 68}$ que o fá\# será incluído trazendo à tona o $4^{\circ}$ modo do gênero diatônico puro (lídio). Trata-se de um período regular de oito compassos. A transcrição apresenta algumas variantes da frase $b$ ' feitas nas repetições.

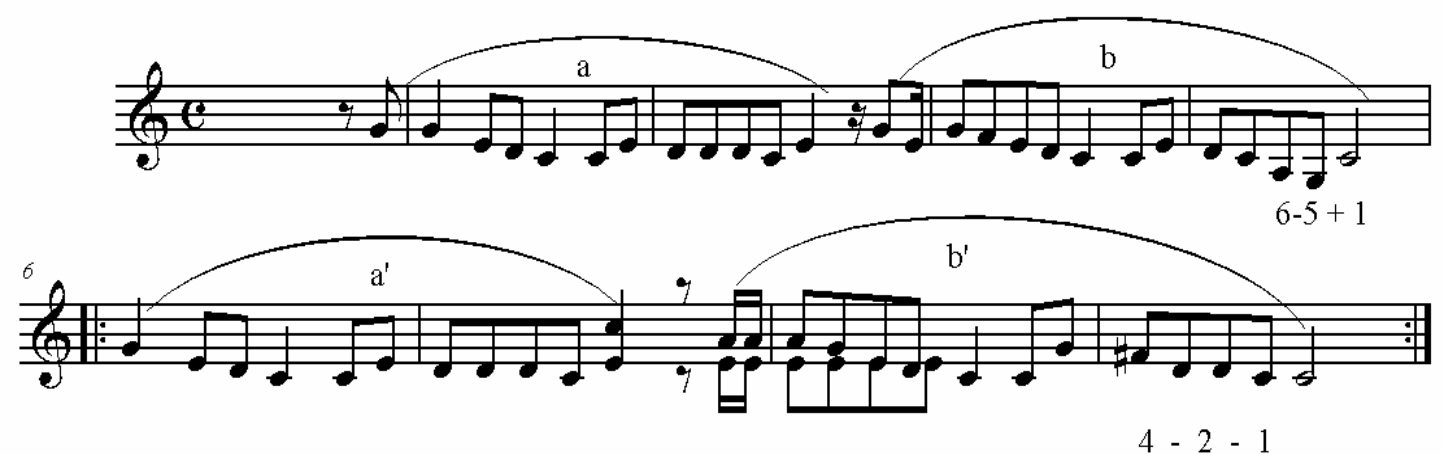

Fig.3.14 - Capoeira: Pisa Caboclo

\footnotetext{
${ }^{68}$ A semifrase final desse canto é exatamente aquela utilizada em Canção do Sal (Milton Nascimento) e Upa, Neguinho (Edu Lobo e Gianfrancesco Guarnieri), como será demonstrado a seguir.
} 
Dentro desses dois universos da cultura afro-brasileira, o candomblé e a capoeira, constatou-se que, na gravação de referência para os cultos, todas as melodias eram pentatônicas (12), enquanto, no segundo caso, os dois exemplos mostrados aqui eram os únicos modais dentro de um universo de 12 melodias.

\subsection{Coco}

Segundo Câmara Cascudo, o coco trata-se de uma dança popular nordestina, cujo refrão é lançado pelo “tirador de coco” e respondido em coro (CASCUDO, 2002, p.147). O cantor e compositor Jackson do Pandeiro é apontado como o responsável pela transposição do coco para as gravações comerciais, de maneira análoga ao que fez Luiz Gonzaga em relação ao baião nas décadas de 1940 e 1950. Os refrões abaixo foram gravados em 1998, na Paraíba (Alegria e Devoção, 2000).

\subsubsection{Novo Quilombo Chegou}

O primeiro a ser analisado é constituído por duas frases que se repetem inúmeras vezes, ora cantada pelo “tirador de coco", ora pelo coro. Encontra-se no $6^{\circ}$ modo do gênero diatônico puro (eólio). É interessante notar a incidência do final 4-1.

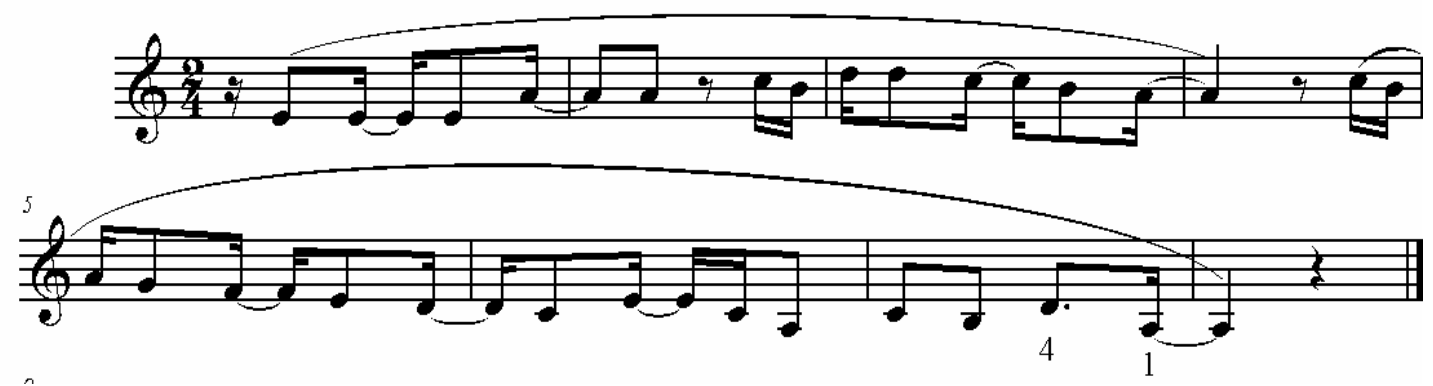

Fig. 3.15 - Coco 1.

Como o texto difere na resposta do coro para o solista, tem-se a impressão de um período cujo conseqüente é literalmente igual ao antecedente. 
Solo: (antecedente)

Coro: (conseqüente)

\begin{tabular}{|l|l|}
\hline Eu 'tava em casa & Antigamente \\
\hline Quando alguém me avisou & Negro não tinha valor \\
\hline Lá no Guruji tem coco & Vamo' brincar minha gente \\
\hline Que Jurandir me chamou & Novo quilombo chegou \\
\hline
\end{tabular}

Tab. 3.1

\subsubsection{De que Lado eu Remo}

A próxima melodia se encontra em modo menor, sem a presença da $7^{\mathrm{a}}$, o que o torna indefinido, entretanto mais próximo do $6^{\mathrm{o}}$ modo (eólio) em virtude da $6^{\mathrm{a}}$ menor. Formado por apenas duas frases, sendo a segunda derivada da primeira. O mesmo fenômeno da melodia anterior acontece: o da impressão de resposta musical quando cantada pelo coro, apesar de musicalmente se tratar da mesma melodia.

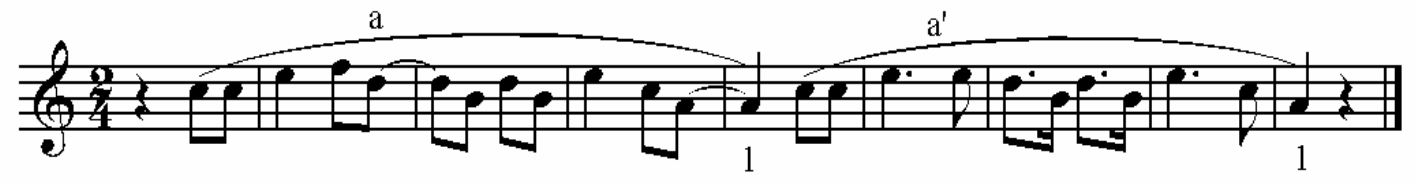

Fig. 3.16 - Coco 2.

Observa-se que nessa melodia as duas frases resolvem na tônica após o arpejo do acorde correspondente. A letra tem estrofes de quatro versos em redondilha menor (cinco sílabas poéticas) e, às vezes, tem seis silabas no primeiro verso, que altera ligeiramente a melodia.

\subsubsection{Estrela D'alva}

Outra melodia no $6^{\circ}$ modo do gênero diatônico puro (eólio) com final 3-1. A frase $a$ é repetida literalmente pelo coro. 

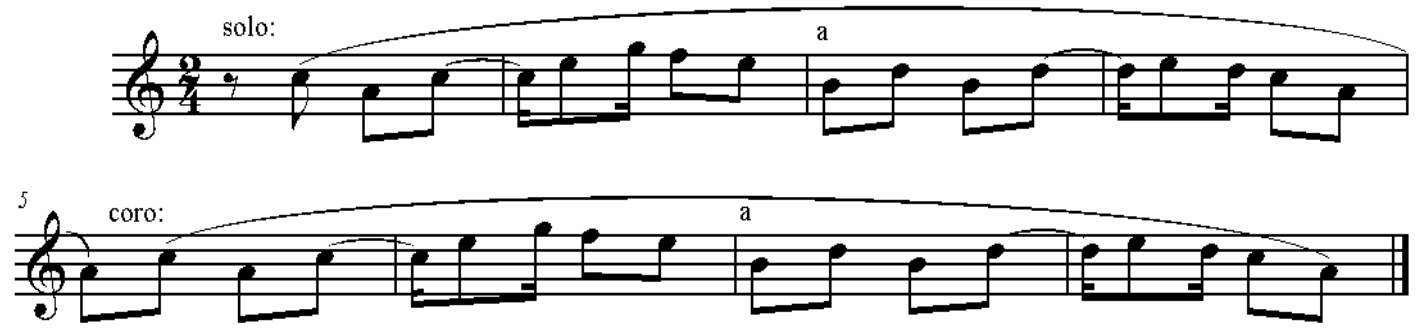

3 - 1

Fig. 3.17 - Coco 3.

\subsubsection{Vai, vai, vai, ô mulher}

A próxima melodia parece pertencer a um misto do $2^{\circ}$ modo do gênero diatônico puro com o final $5^{\mathrm{a}}$ abaixo (hipodórico). Isto porque há o uso das notas fá natural e fá sustenido, bem como o final 4-1 do primeiro coco, considerando-se o lá como nota dominante do modo. Como no coco anterior, trata-se de duas frases derivadas.

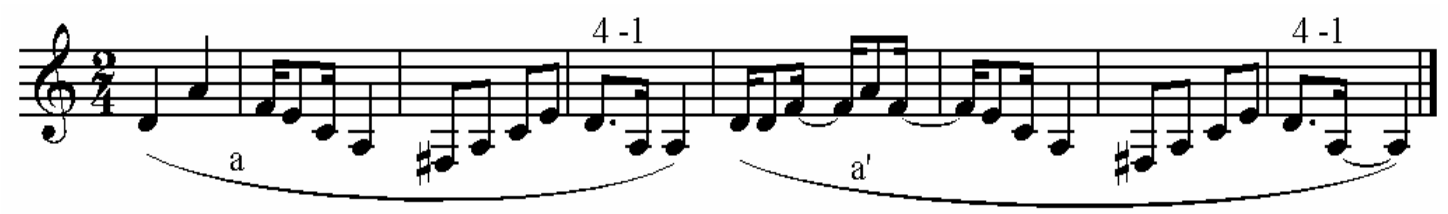

Fig. 3.18 - Coco 4.

\subsubsection{Eu Vou, Marido eu Vou}

O próximo coco se encontra no $2^{\circ}$ modo do gênero diatônico puro (dórico), composto de duas frases que não são derivadas e que finalizam, respectivamente, na $5^{\mathrm{a}}$ e na tônica do modo (1).

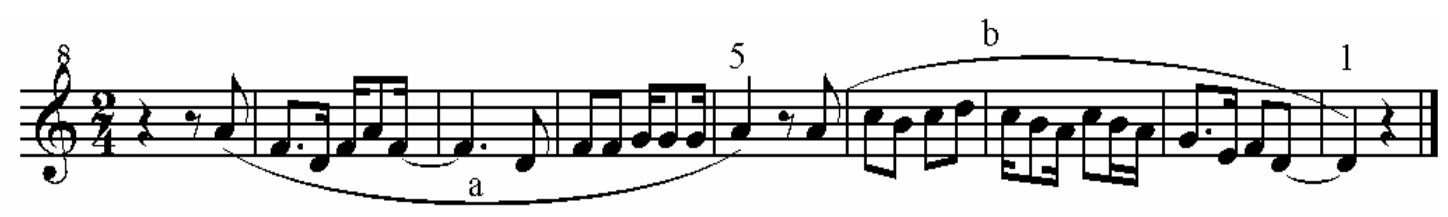

Fig. 3.19 - Coco 5. 


\subsection{6 Ô Mulher, Você foi Embora}

O próximo exemplo apresenta um híbrido entre modos menor e maior. Ambos sem a presença da sensível tonal nas frases $b$ e $d$. As duas primeiras frases poderiam estar no $3^{\circ}$ modo do gênero diatônico (hipoeólio) ${ }^{69}$ sem o $2^{\circ}$ grau com o final 6+1, cujo do\# não pertence ao modo. Nas duas últimas frases, nas quais há a resposta masculina, parece que o centro modal converge para o $1^{o}$ modo do gênero diatônico puro (jônio) sem $7^{\mathrm{a}}$ e $5^{\mathrm{a}}$, mas com o mesmo final cadencial: 6+1. A melodia completa possui 16 compassos com um antecedente de oito compassos realizados pelas mulheres e o conseqüente de oito compassos com o solo masculino, que é a resposta. ${ }^{70}$

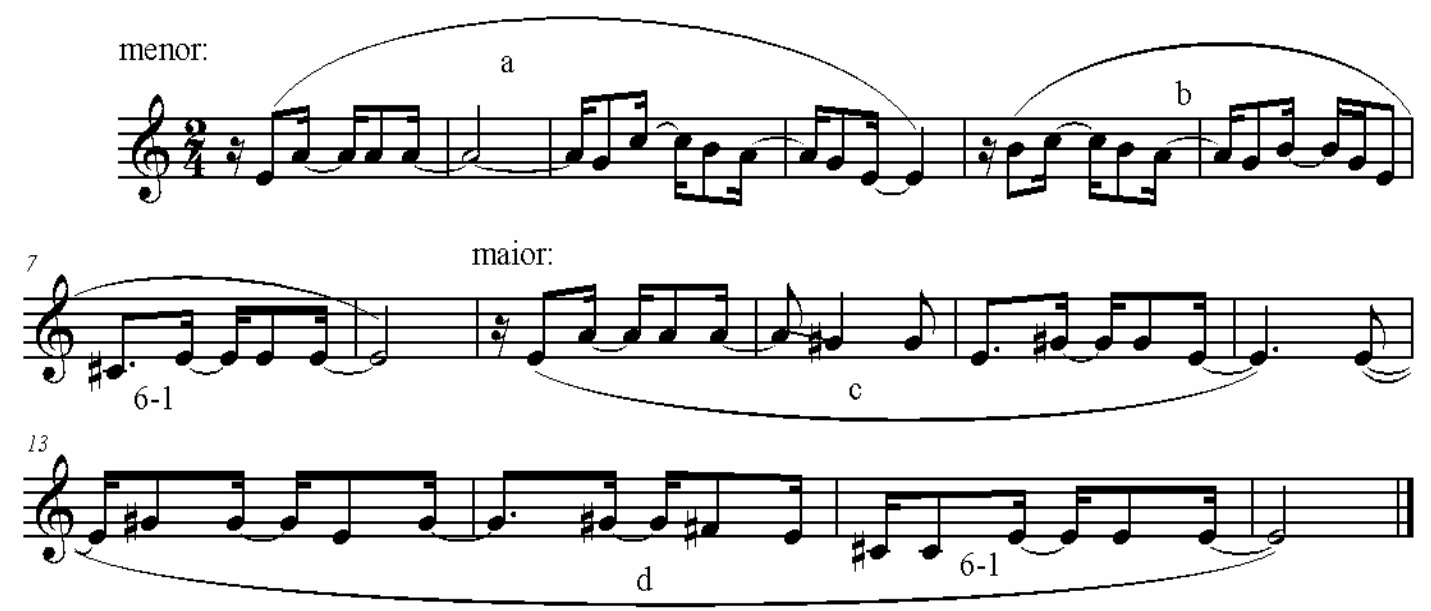

Fig. 3.20 - Coco 6.

\subsubsection{No Rio Chegou um Peixe}

A próxima melodia está baseada no $5^{\circ}$ modo do gênero diatônico puro (mixolídio). O solista canta quatro frases de quatro compassos com início em anacruse - elemento também característico do baião - que sempre finalizam na $3^{\mathrm{a}}$ do modo. A resposta do coro é constituída por apenas duas frases. Parece que todo o conjunto melódico é formado por pequenas variantes a partir da primeira frase.

\footnotetext{
${ }^{69}$ Baseado no fato de a nota dominante na acepção gregoriana deste modo ser o $4^{\circ}$ grau, o que corresponderia ao modo menor natural com o salto 5-1 ascendente.

${ }^{70}$ No antecedente, as mulheres dizem o seguinte: Eu me calei/ não disse nada/ mulher malvada/ não é assim que se faz; e o solo diz: Mas ô mulher/ você foi embora/ fiquei pensando/ de você não mais voltar.
} 


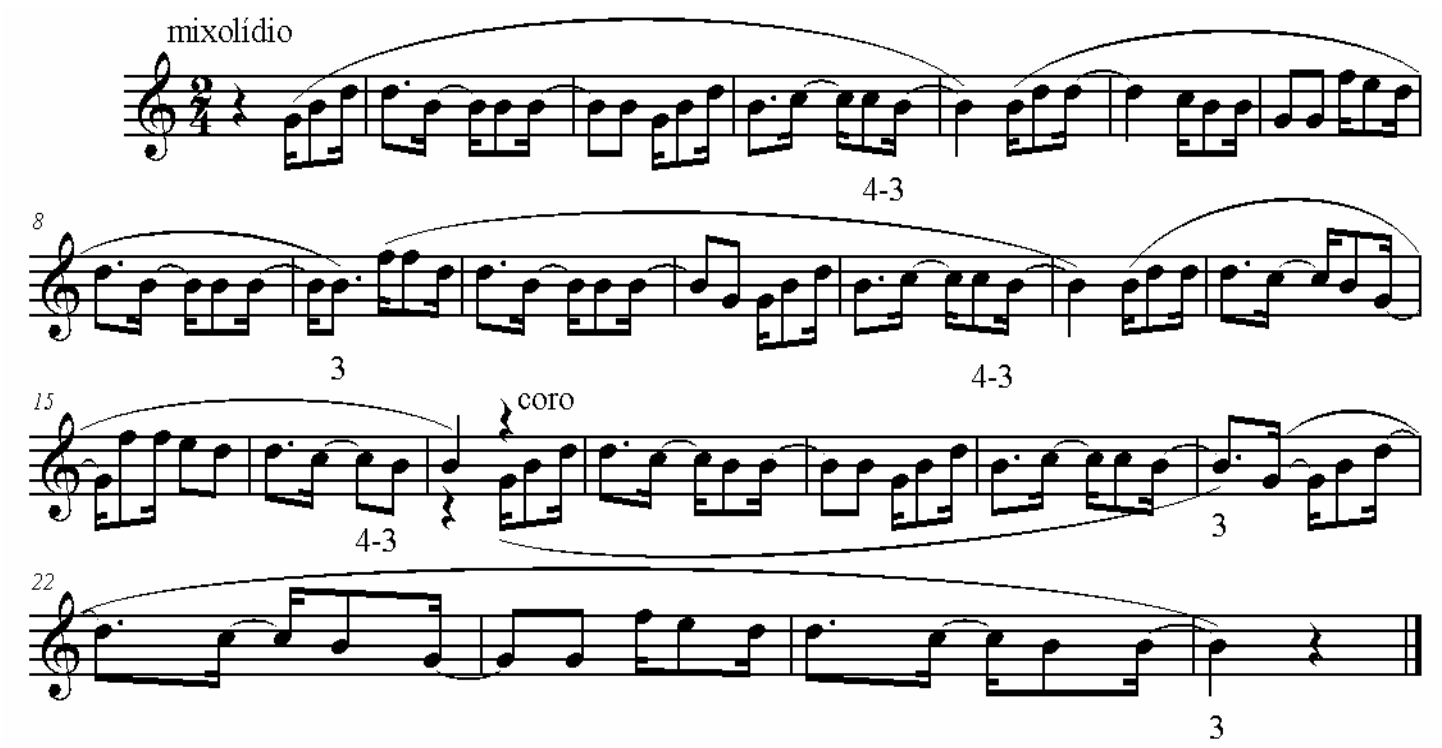

Fig. 3.21 - Coco 7.

\subsubsection{Saudação}

Passa-se agora a ilustrar o modalismo no coco através de outra gravação: Zambê (1999). O presente coco (Zambê, 1999, faixa 1) encontra-se no hexacórdio do $4^{\circ}$ modo do gênero diatônico puro (lídio sem a $7^{\mathrm{a}}$ ). Ressalta-se o salto $6+1$ no interior da frase $a$, as cadências 1+3-1 e 3-1 e a regularidade fraseológica de oito compassos.

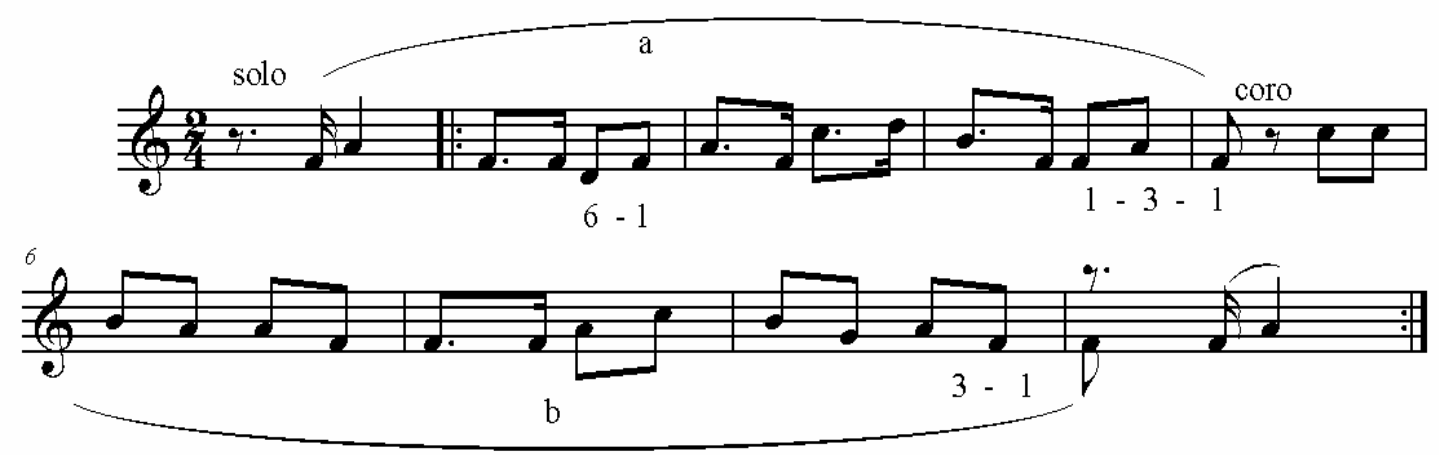

Fig. 3.22 - Coco 8.

\subsubsection{Usina Grande}

O próximo exemplo (Zambê, 1999, faixa 2) se encontra no $5^{\circ}$ modo (mixolídio). O solista apresenta as frases $a$ e $b$ que são respondidas com alterações pelo coro $a^{\prime}$ e $b^{\prime}$. As 
frases são de quatro compassos cujos finais são $5+7$, frase $a$ interrogativa e $1+3+5$, frase $b$ afirmativa. Os mesmos finais ocorrem na repetição alterada do coro.
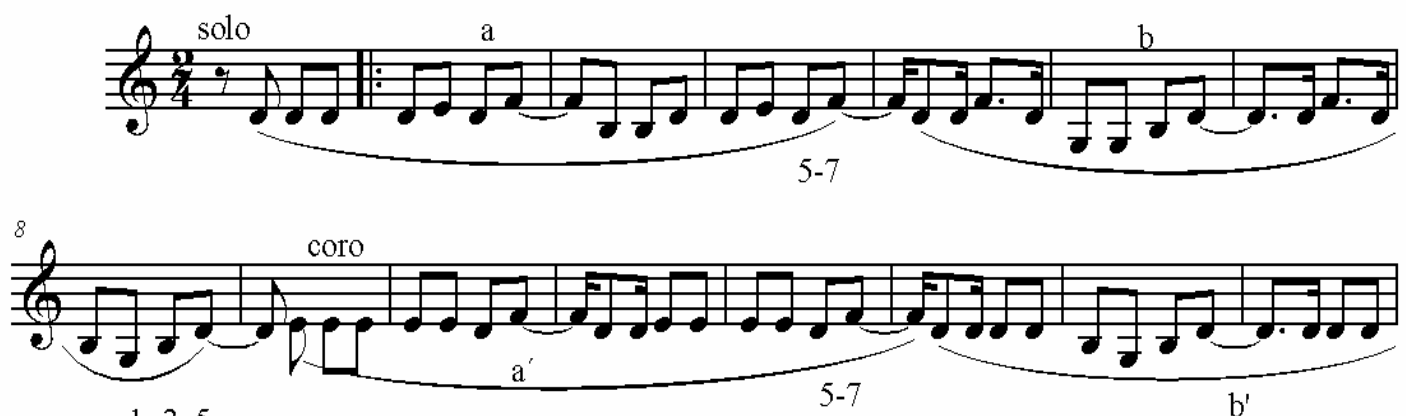

$1-3-5$

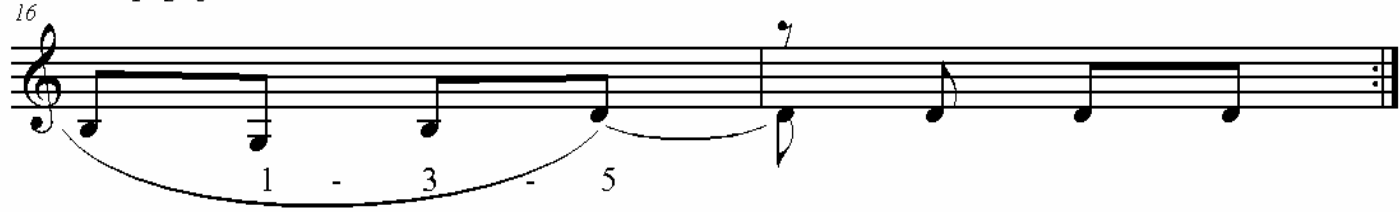

Fig. 3.23 - Coco 9.

\subsubsection{Sem Título}

Comparar-se-ão agora dois cocos transcritos a partir do registro da Missão, de 1938. O primeiro deles vem da cidade de Patos, estado do Pará, faixa 14 do $2^{\circ} \mathrm{CD}$. No $2^{\circ}$ modo do gênero diatônico puro (dórico) com apenas duas frases, $a$ e $b$, com final 4-1. A frase interrogativa (a) repousa na nota dominante (5).

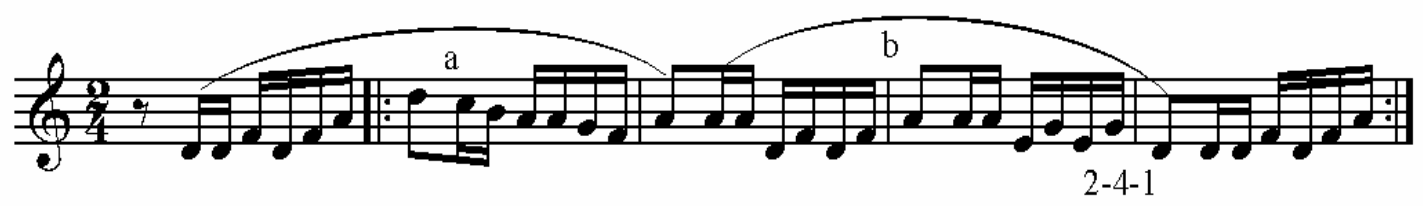

Fig. 3.24 - Coco 10

\subsubsection{Eu Pisei na Ponte}

O último exemplo, também da Missão, traz um dado interessante: o texto é praticamente idêntico àquele selecionado por Andrade (1991, p. 137) em seu texto sobre samba rural paulista. Enquanto o primeiro diz "Eu Pisei na ponte/ A ponte estremeceu/ a água 
tem veneno morena/ Quem bebeu morreu", o texto paulista diz "Fui passa na ponte". Entretanto, a melodia de Pirapora está em tonalidade maior e a aqui apresentada encontra-se em modo menor ( $6^{\circ}$ - eólio) sem presença de sensível (sol\#). ${ }^{71}$ Estrutura-se de maneira ternária devido à repetição da primeira frase $(a)$. Como no exemplo anterior, essa frase é interrogativa, resolvendo na nota dominante (5) e a última é conclusiva, realiza o final 2-1. Ela consta na $43^{\mathrm{a}}$ faixa do $2^{\circ} \mathrm{CD}$, gravada em Pombal, estado do Pará.

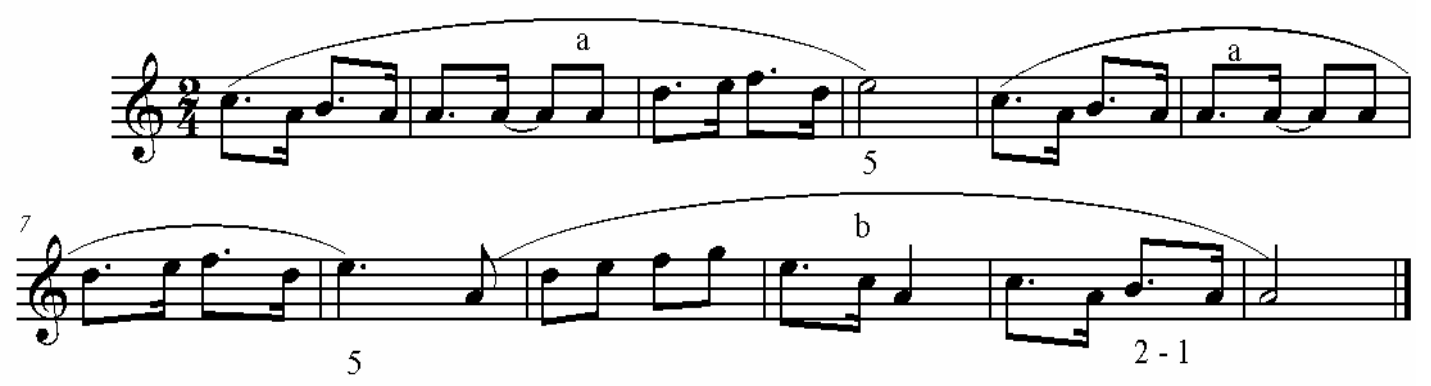

Fig. 3.25 - Coco 11.

As melodias aqui selecionadas não representam a totalidade das melodias modais encontradas nessas duas gravações; dentro de uma totalidade de 45 melodias, 14 são modais.

Na obra Os Cocos, de Mário de Andrade (2002), são apresentadas 245 melodias do gênero ligadas a diferentes assuntos (coco das coisas, dos homens, das mulheres, etc.). Foram classificadas 28 como modais, sendo dez pertencentes ao $6^{\circ}$ modo - eólio - do gênero diatônico puro ( $\mathrm{N}^{\mathrm{o}}$ 54, 62, 63, 64 - sendo este uma variante da melodia anterior -, 84, 120, 134, 137, 202 e 235); seis pertencentes ao $5^{\circ}$ modo - mixolídio - do mesmo gênero ( $\mathrm{N}^{\mathrm{o}} 56$ com final tonal -, 73 - hipomixolídio -, 123 -b -, 140, 152, 191); cinco no $2^{\circ}$ modo - dórico (53, 110 - hipodórico -, 153, 154 - variante do anterior -, 156); quatro pertencentes ao $1^{\circ}$ modo - jônio - sem sensível e com o traço melódico 6+1 ( $\mathrm{N}^{\circ}$ 65, 129, 133, 195); um caso híbrido (218), um caso no $4^{\mathrm{o}}$ modo - lídio - (161) e um indefinido entre um jônio sem $7^{\mathrm{a}}$ ou eólio sem $2^{\mathrm{a}}$ (176).

\subsection{Catimbó}

Segundo Cascudo (2002, p. 122), o catimbó é uma reunião de pessoas que buscam conselhos dos mais variados na figura de um mestre. Para isso, incorpora espíritos e cada um

\footnotetext{
${ }^{71}$ Outro exemplo dessa mesma letra aplicada à outra melodia encontra-se em Andrade, 2002, p. 83.
} 
deles tem uma linha ou ponto próprio, que é uma pequena melodia. Nesse culto há uma série de elementos sincréticos advindos da cultura afro-brasileira, indígena e católica. A gravação escolhida foi a das Missões de Pesquisas Folclóricas, de 1938, dirigida por Mário de Andrade. As linhas aqui apresentadas foram colhidas, portanto, no estado da Paraíba, e as transcrições revisam aquelas apresentadas por Álvaro Carlini (1993). É importante ressaltar que, ao contrário do coco e do candomblé, o ritmo é muito mais livre e, de certa forma, rubato, o que torna mais difícil a acuidade rítmica da transcrição.

\subsubsection{Mestre Manuel Cadete}

O primeiro ponto aqui apresentado está situado no $5^{\circ}$ modo (mixolídio). As frases se resolvem na tônica (1) ou na quinta (5) nota do modo. Formalmente a linha apresenta: Introdução de quatro compassos formada pelas frases $a^{72}$ e $b$, A de doze compassos (estrutura ternária), formado pelas frases $c$ e $d$, sendo a última repetida, B de oito compassos formado pela repetição da frase e $C$, de oito compassos. Após essas frases há a repetição parcial das seções A (frase $d$ ) e B.
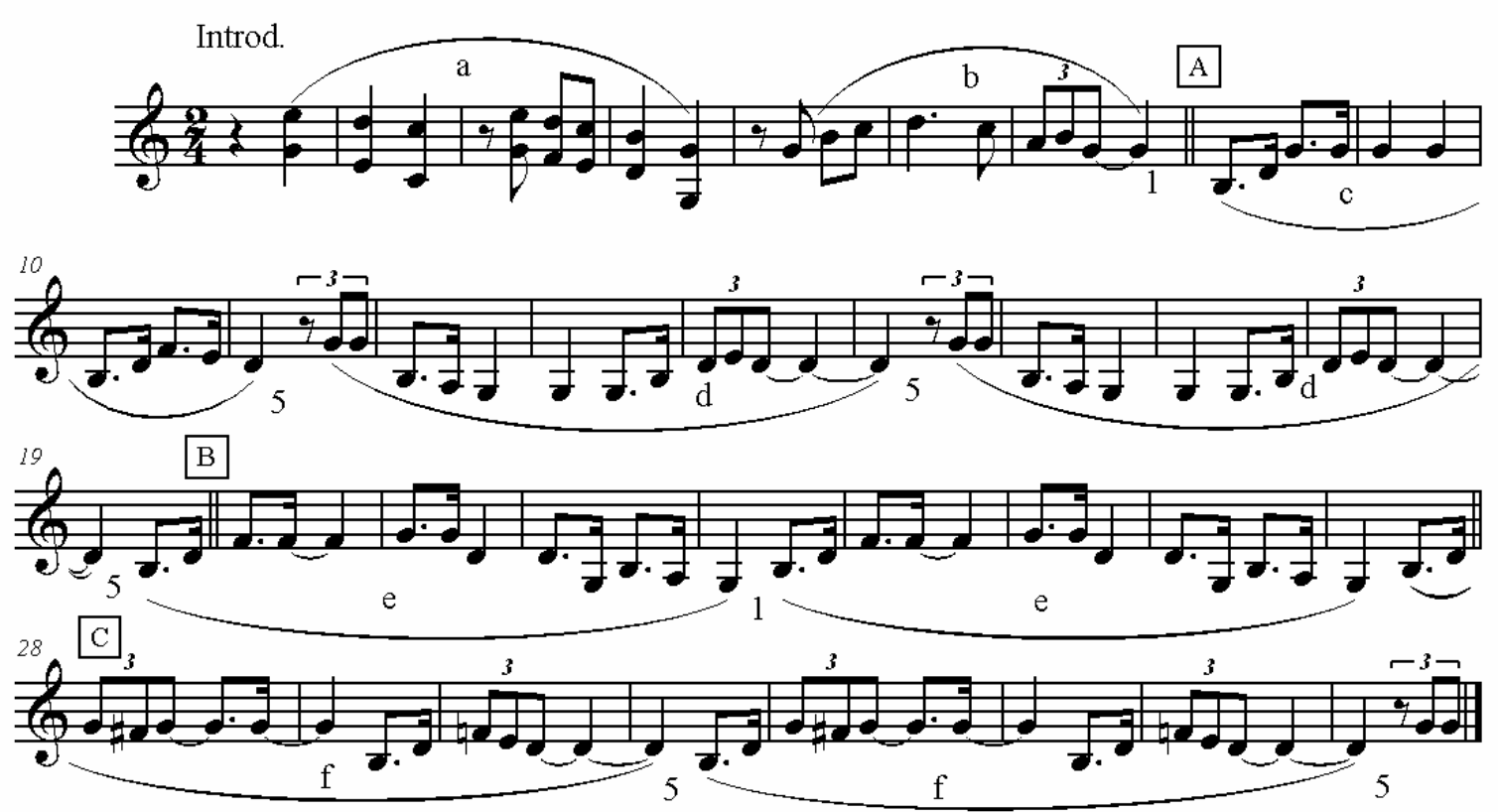

Fig.3.26 - Catimbó 1

\footnotetext{
${ }^{72} \mathrm{~A}$ frase $a$ parece pertencer à escala maior; entretanto, as frases posteriores já estabelecem o modo predominante.
} 
Durante a seção $C$ há a presença da nota fa\#, que certamente não pertence ao $5^{\circ}$ modo (mixolídio). Entretanto, funciona como uma nota aproximação cromática, não alterando o efeito modal da totalidade do ponto.

\subsubsection{Mestre José Fulo da Noite ou Mestre Adivinhão}

A segunda linha escolhida é composta por três frases ( $a, b$ e $c$ indicadas pela linha contínua) subdivididas em semifrases ( $x, y, z, z$ ’, $z$ ” e $w$ indicadas pela linha pontilhada) que abrangem catorze compassos. Se, do ponto de vista das frases, não há repetição, a seqüência de semifrases $z$ ajuda na unidade da estrutura (ternária e irregular). Também no $5^{\circ}$ modo (mixolídio) e com finais na tônica (1), terça (3) e quinta (5).

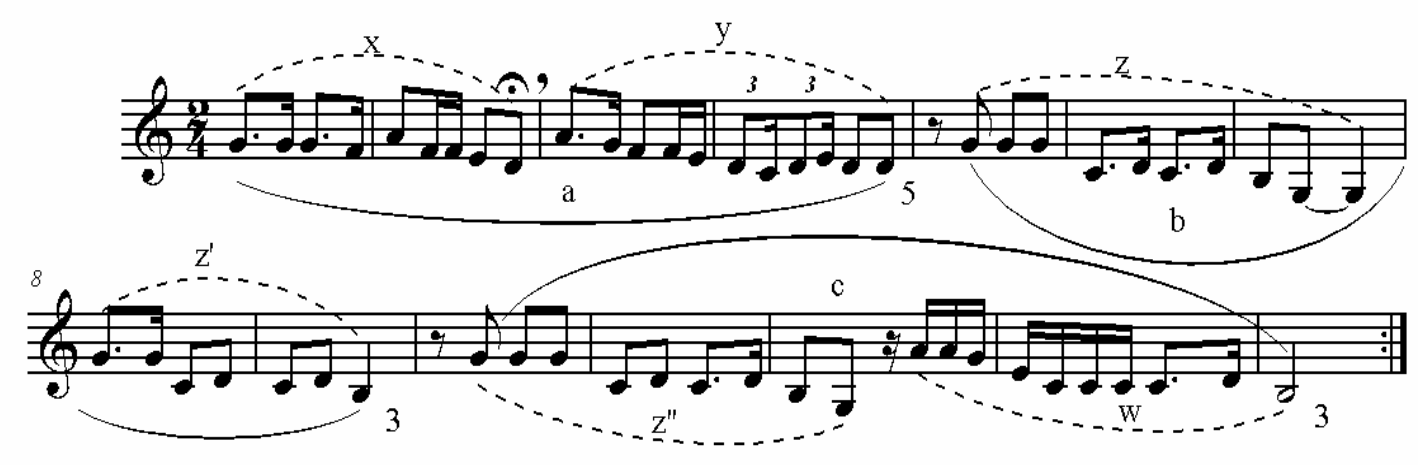

Fig.3.27 - Catimbó 2

\subsubsection{Mestre Dom João do Outro Mundo}

O terceiro ponto apresentado se encontra no $5^{\circ}$ modo (mixolídio), possui uma quadratura de 16 compassos formados pela repetição literal das frases $a$ e $b$. A frase $a$ finaliza na tônica do modo (1) e a frase $b$ na quinta (5). 

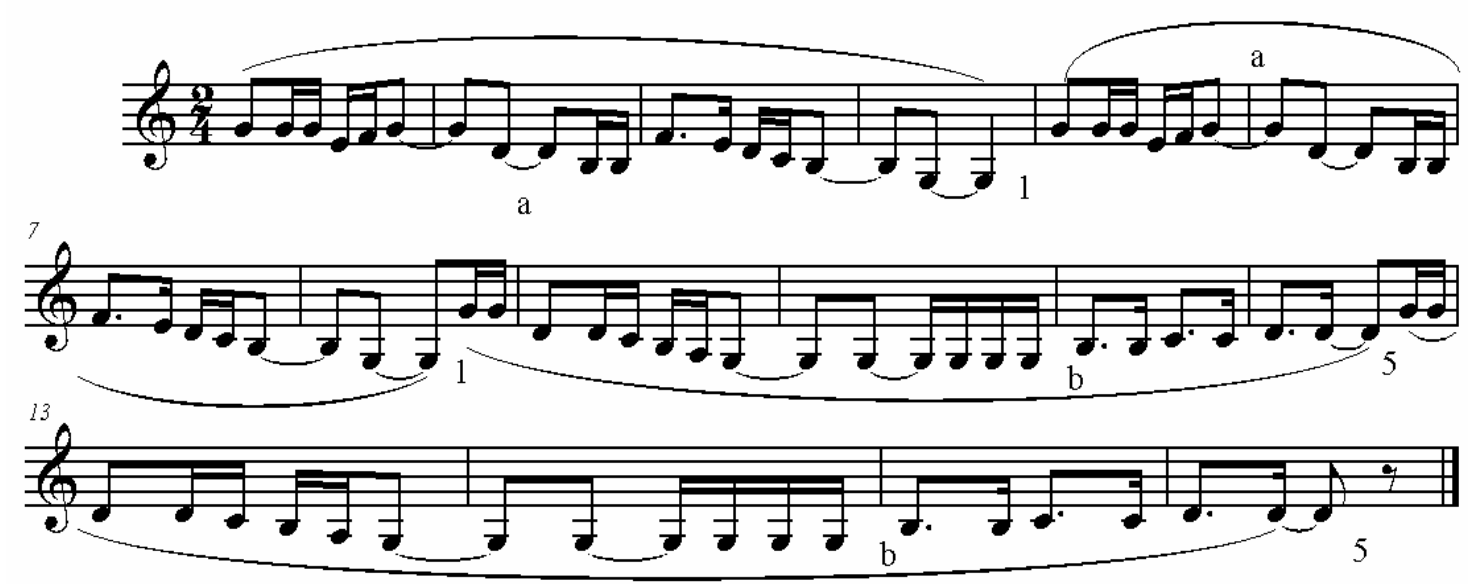

Fig. 3.28 - Catimbó 3

\subsubsection{Mestre Menino}

Este canto, que se assemelha a uma cantiga de ninar ${ }^{73}$, é um dos raros exemplos encontrados no $4^{\circ}$ modo do gênero diatônico puro (lídio). A frase $a$ ocupa a tessitura de um pentacórdio com a $4^{\text {a }}$ elevada e com o final na $3^{\text {a }}$ maior. A frase $b$ tem um âmbito também de um pentacórdio, agora com $3^{\mathrm{a}}$ menor e terça menor abaixo do primeiro. Entretanto, o final da melodia se dá na tônica do modo mencionado. É importante ressaltar o anacruze e o final da frase $b$ : $6+1$ e 6+7+1. Com um total de 16 compassos, as frases $a$ e $b$ se repetem literalmente.
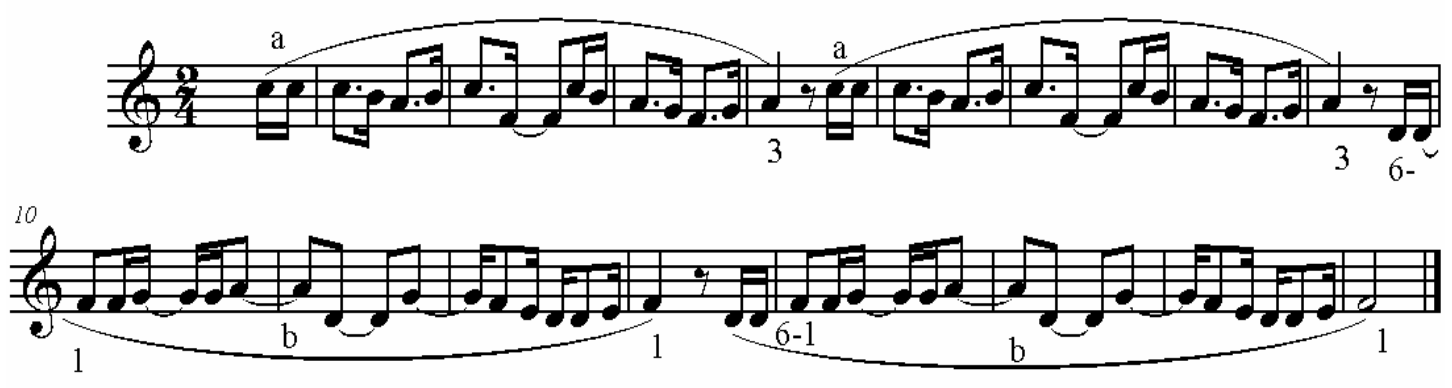

Fig.3.29 - Catimbó 4

\subsubsection{Mestre Laurinda ou Mestre Lauriano}

O próximo exemplo é híbrido: composto por duas frases que se repetem literalmente, pertence ao $2^{\circ}$ modo (dórico) do gênero diatônico puro na frase $a$ e ao $5^{\circ}$ modo (mixolídio

73 “O menino está chorando/ Lá na torre de Belém/ Cala a boca meu filhinho/ Que tua mãe logo vem”. 
sem $2^{a}$ ) de sol maior na frase $b$, através da alteração da terça. Todas as terminações fraseológicas ocorrem no $5^{\circ}$ grau dos modos.

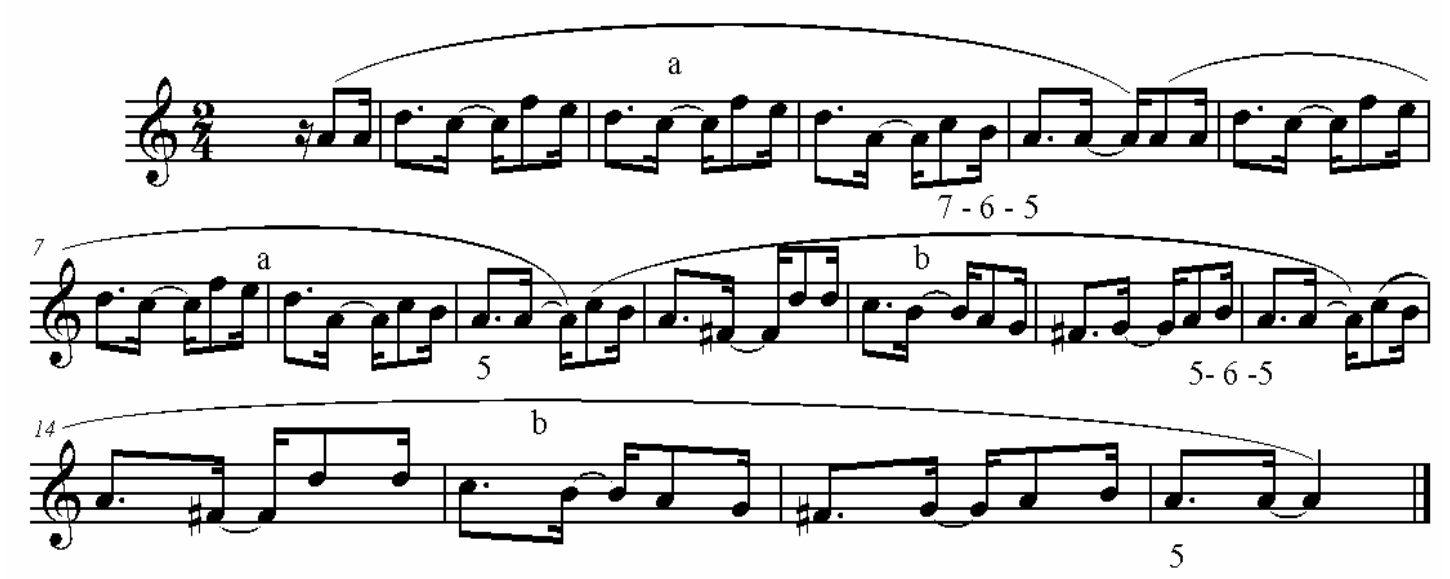

Fig.3.30 - Catimbó 5

\subsubsection{Mestre Caboclo Daniel}

Este ponto traz algo semelhante com a sentença, coisa que não acontecia nas melodias anteriores devido às repetições literais. Com a diferenciação ocorrida na frase $b^{\prime}$, que se altera para finalizar na tônica (1), ela se assemelha a uma frase cadencial, enquanto a resolução na $7^{\mathrm{a}}$ da frase $a$ e na $5^{\mathrm{a}}$ na frase $b$, conferem caráter suspensivo.

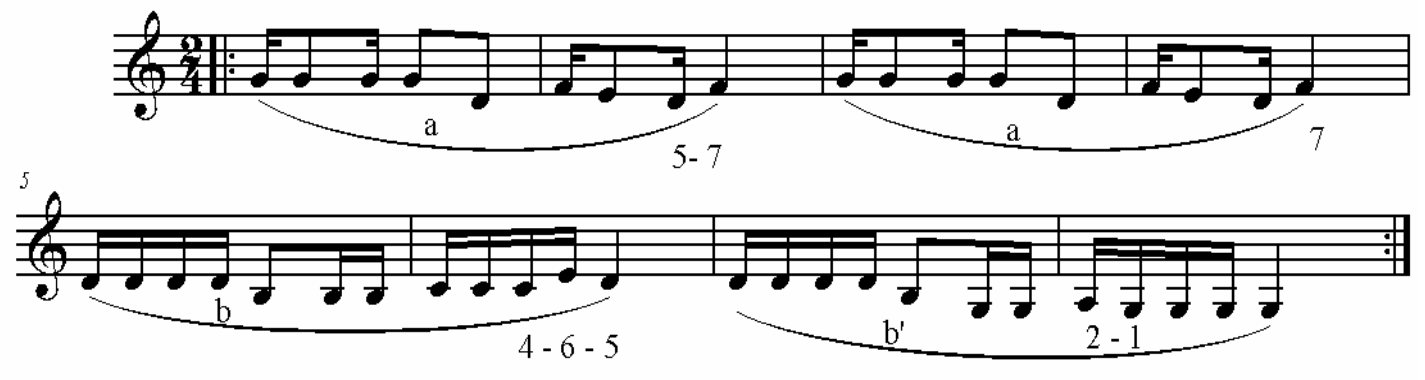

Fig.3.31 - Catimbó $6^{74}$

\subsubsection{Mestre Belarmina ou Mestre Belarmino}

Mais um exemplo híbrido: a frase $a$ é tonal, como indica a nota fa\# apontando para sol maior e as frases $b$ e $b^{\prime}$ - que só diferem no ritmo - se encontram no $5^{\circ}$ modo (mixolídio). Todas as finalizações se dão na nota dominante (5). ${ }^{75}$

\footnotetext{
${ }^{74}$ Esta melodia traz traços bastante semelhantes àqueles encontrados na melodia XL recolhida por Mário de Andrade em Recife entre 1928 e 1929, também em culto de Catimbó. Ver Andrade, 1983, p.98.
} 


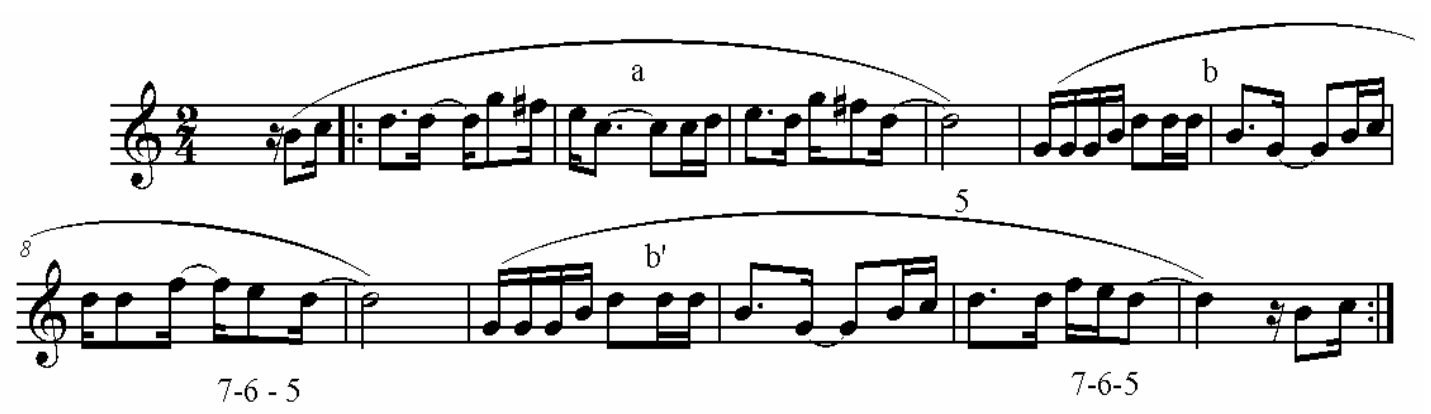

Fig.3.32 - Catimbó 7

\subsubsection{Mestre do Envultamento}

O último exemplo de Catimbó estudado aqui é bastante semelhante ao anterior: em estrutura ternária, modalmente híbrido e com finais de frases iguais (3-2-1). Entretanto, todas as frases pertencem ao $5^{\circ}$ modo (mixolídio) em diferentes transposições: a frase $a$ está no $5^{\circ}$ modo de fá maior e as frases b no $5^{\circ}$ modo de dó (sol mixolídio).

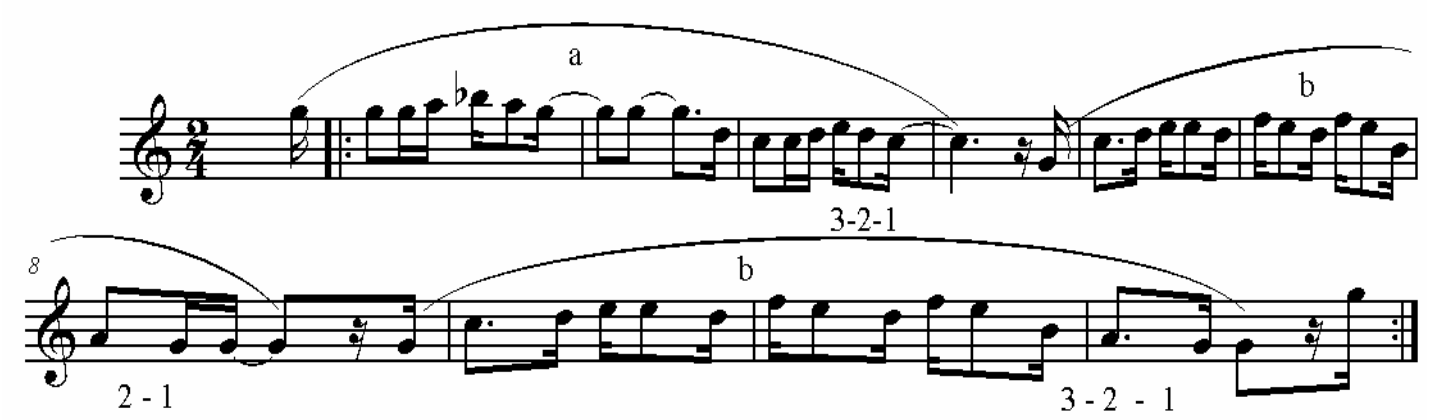

Fig.3.33 - Catimbó 8

Como no caso dos cocos, não foram expostas aqui todas as melodias modais encontradas no catimbó da Missão, evitando-se a repetição de características já apresentadas. A obra de Carlini (1993) apresenta 64 melodias, das quais classificaram-se 21 como modais.

Das 44 melodias de catimbó recolhidas por Mário de Andrade entre 1928 e 1929 entre Paraíba e Pernambuco, apresentadas na obra Música de Feitiçaria no Brasil (1983), dez são modais, estando uma no $4^{\circ}$ modo do gênero diatônico puro (lídio): XVIII - p. 84; duas no $6^{\circ}$ modo (eólio): V - p.76 e XXIII - p.87- e sete no $5^{\circ}$ modo (mixolídio) - XX - p.85, XXX p.92, XXXII - p.93, XXXIV e XXXV - p.95, XXXIX - p.97, XL e XLI - p.98. Como já

\footnotetext{
${ }^{75}$ Portanto, tomaram-se como referência à centralidade da melodia as frases que concluem o ponto, subordinando a frase $a$ a frase $b$.
} 
referido em nota, algumas, principalmente aquelas no $5^{\circ}$ modo, apresentam traços bastante semelhantes às melodias levantadas aqui como os finais 6+1 (XXXIV e XXXIX) e 3-2-1 (XXXV) e semicadência ou final do antecedente 1+3 (XXXIX). Há também aquelas com finais plagais, ou seja, na $5^{\mathrm{a}}$ nota do modo (XXXI, XXX e XX).

\subsection{Cantoria}

A arte da cantoria, segundo Cascudo (2002, p. 192) e Ramalho (2000, p. 74), remonta aos gregos e permeou a Idade Média e Renascença principalmente na vertente do desafio. $\mathrm{O}$ papel da oralidade e da memória aqui se faz presente, pois, segundo Francisca Borges ${ }^{76}$, os folhetos da literatura de cordel eram memorizados pelos cantadores e interpretados diante do público. Com o passar do tempo, os cantadores passaram a improvisar os versos dentro de métricas e rimas predeterminadas. Dessa forma, uma única linha melódica serve de suporte para vários versos poéticos, ressaltando o papel da poesia como o elemento estruturador da melodia. As linhas melódicas apresentadas foram retiradas dos CDs A Arte da Cantoria: ciclo do Padre Cícero e A Arte da Cantoria: ciclo do Cangaço, ambos lançados em long playing pela Funarte-Fundação Nacional da Arte, na década de 1980, e relançados recentemente pelo Itaú Cultural.

\subsubsection{Os Sacrifícios de São Cícero Romão}

A melodia de Os Sacrifícios de São Cícero Romão, colhida em Maceió, estado de Alagoas, em 1977 (A Arte da Cantoria, Ciclo do Padre Cícero, faixa 1), apresenta alguns elementos bastante característicos da prática da cantoria: $5^{\circ}$ modo (mixolídio), frase em anacruse com arpejo ascendente ${ }^{77}$ e terminação melódica $6+1^{78}$. Esta melodia, assim como os demais cantos de cantoria, sofre ligeiras modificações no decorrer da performance e, em certos pontos, algumas notas duram um pouco mais ou menos, gerando compassos irregulares que acontecem em função de uma hesitação ou respiração do cantador.

\footnotetext{
${ }^{76}$ Texto do encarte do CD A Arte da Cantoria: Cangaço. São Paulo: Itaú Cultural, s/d.

${ }^{77}$ Como em Baião, de Luiz Gonzaga.

${ }^{78}$ Como em Mulher Rendeira, melodia de domínio público atribuída às vezes a Zé do Norte (?).
} 


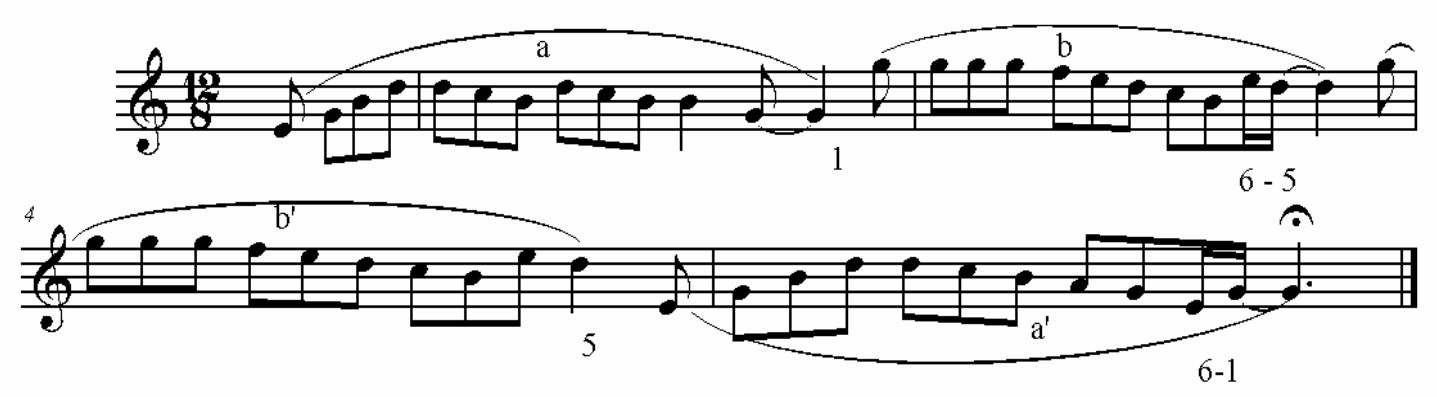

Fig.3.34 - Cantoria 1

\subsubsection{Promessa ao Padre Cícero}

Esta cantoria (A Arte da Cantoria, Ciclo do Padre Cícero, 1985, faixa 3) tem uma estrutura muito semelhante ao canto anterior. Quatro frases em 12/8 de um compasso cada uma, todas anacrúzicas e ditribuídas em $a, b, b^{\prime}$ e $a^{\prime}$. A novidade está no modalismo misto entre o $4^{\circ}$ modo do gênero diatônico híbrido (mixolídio com $4^{\mathrm{a}}$ aumentada) ${ }^{79}$ na introdução de do\# e $5^{\circ}$ modo do gênero diatônico puro (mixolídio) convencional do gênero com o do natural.

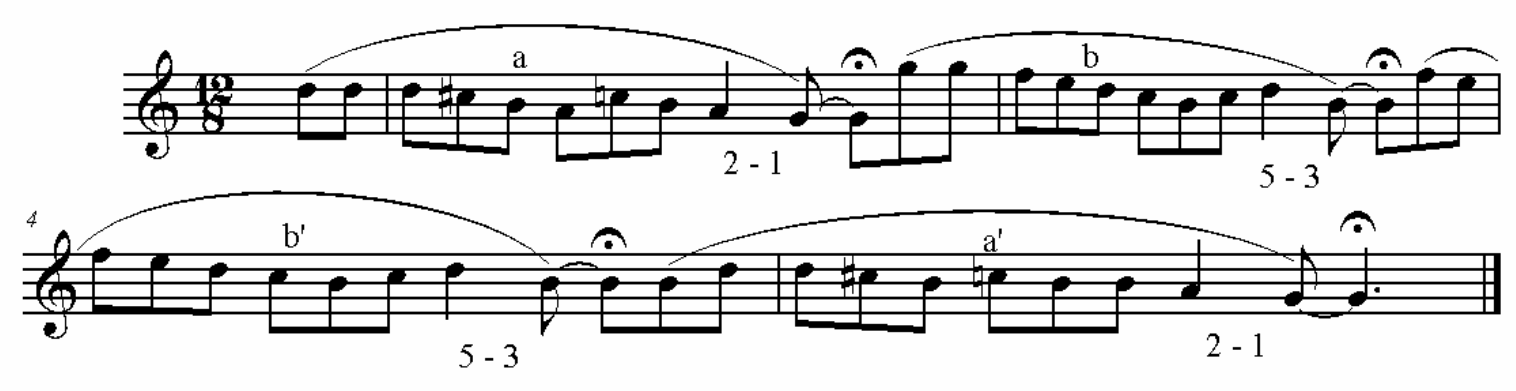

Fig.3.35 - Cantoria 2

\subsubsection{Sextilhas}

O terceiro canto mostra mais uma vez a estruturação musical a partir do poema. Nesse caso, trata-se de um desafio e, portanto, a poesia é improvisada. Dos gêneros poéticos utilizados pelos cantadores, a Sextilha (1985, faixa 5) é um dos mais populares. Trata-se de várias estrofes de seis versos em redondilha maior (versos de sete sílabas). Observa-se que há na música uma repetição extra da frase $b$, perfazendo, assim, uma estrutura ternária de seis compassos, conseqüência direta do uso da sextilha. O modo utilizado foi o $6^{\circ}$ do gênero

\footnotetext{
${ }^{79} 4^{\mathrm{o}}$ modo da escala bachiana.
} 
diatônico puro (eólio), apesar das tríades maiores tocadas na viola pelos cantadores. Há algumas repetições de notas características da música nordestina, em que a primeira nota está na parte fraca da figura e a nota repetida, na parte forte, fazendo o final 3+4-4-3 na frase $a$ e 3-2-2-1 na frase $b$. No interior dessa mesma frase (compassos 3+4) há também a repetição 43-3-2-2 e na frase $a$ o mesmo motivo que faz 6-5-5-4-4.

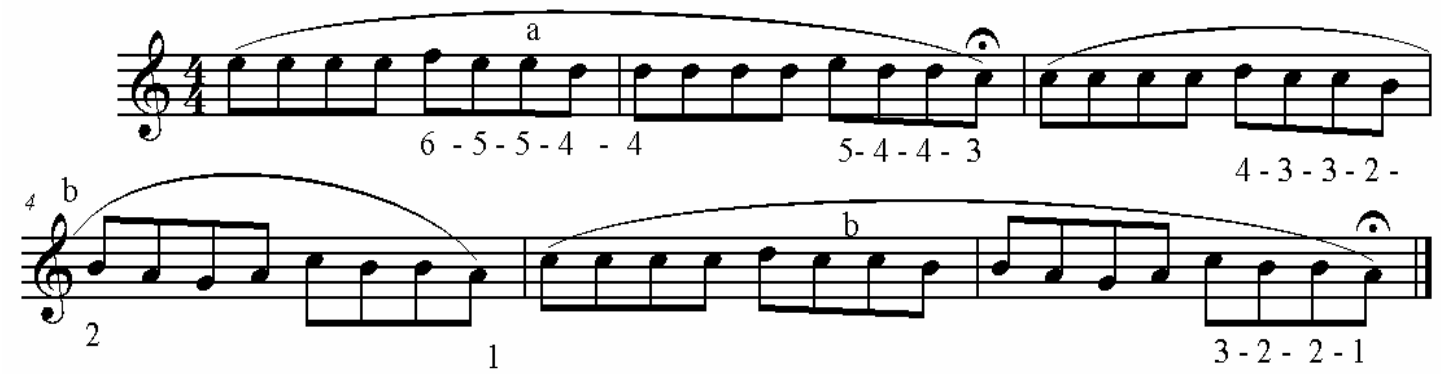

Fig.3.36 - Cantoria 3

\subsubsection{Oito Pés à Quadrão/ Dez Pés à Quadrão}

A próxima cantoria (1985 - faixa 6) se divide em três partes: a primeira, na qual a melodia é colocada conforme a métrica poética dos Oito Pés à Quadrão, ou seja, oito versos com 7 sílabas cada. Após esse começo, a melodia se estabelece na forma escrita para, na última parte, introduzir-se a métrica dos Dez Pés à Quadrão, ou seja, dez versos de 7 sílabas, cuja frase intercala oito vezes entre um cantador e outro para, no final, cantarem juntos a cadência que completa a estrutura. Como características principais, notam-se:

1. Notas repetidas tanto no interior das frases como nas cadências (finais de frases);

2. A já assinalada em outro momento cadência 6+1;

3. Frases em anacruse de quatro compassos;

4. $5^{\circ}$ Modo (mixolídio);

5. Final de frase na $3^{\mathrm{a}}$ quando interrogativo e na tônica (1) quando conclusivo.

Um dado interessante é a similaridade da frase dos Dez Pés à Quadrão com a da melodia do baião Maçã do Rosto, de Djavan, gravado nos anos 1970. 


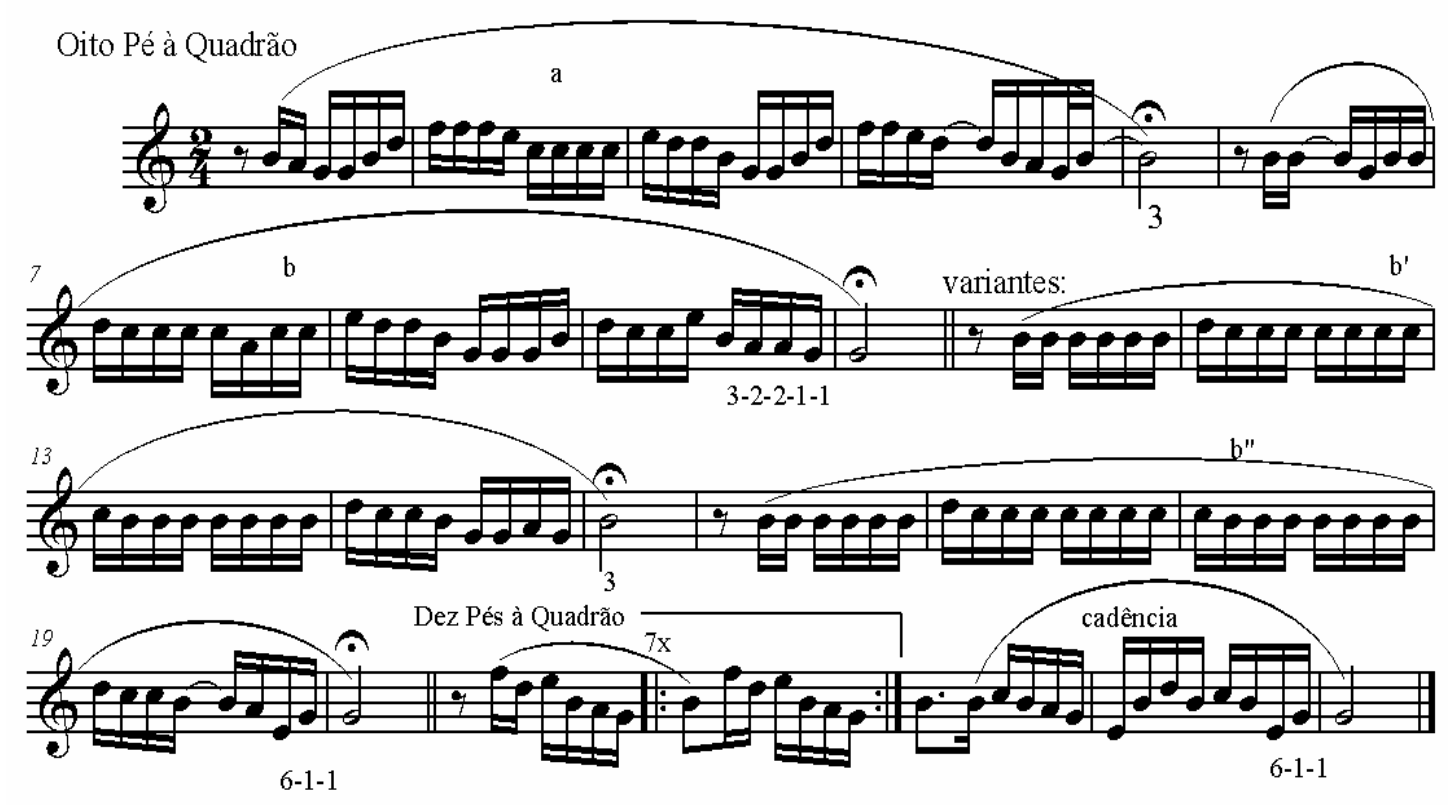

Fig.3.37 - Cantoria 4

\subsubsection{Vida, Sofrimento e Glória do Padre Cícero Romão}

O último exemplo (1985, faixa 7) aqui apresentado encontra-se no hexacórdio do $4^{\circ}$ modo (lídio), ou seja, no referido modo sem a $7^{\mathrm{a}}$, que poderia ser menor perfazendo o $4^{\circ}$ modo do gênero bachiano (mixo11+ ou lidio7b). A letra $F$ indica o acorde de fá maior tocado pela viola, isso porque ele é parte importante para que se perceba o modo de fá. Quando se ouve apenas melodicamente, tem-se a impressão de se tratar do modo de lá menor. Novamente notam-se os mesmos elementos: notas repetidas e o movimento 6+1, mas aqui no início da frase cadencial.

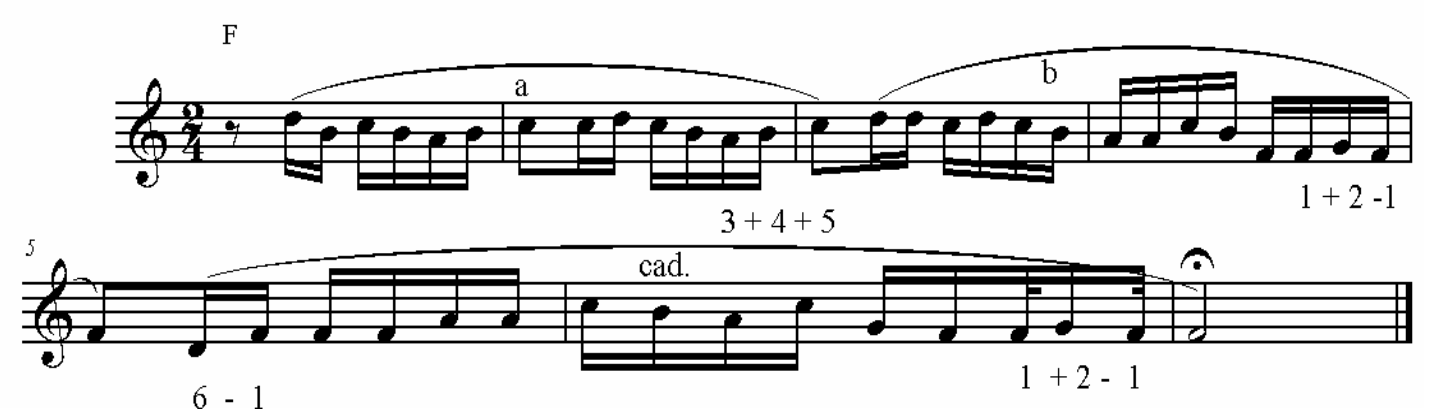

Fig.3.38 - Cantoria 5 


\subsubsection{Eu também sou Cangaceiro/ Minha Arma é a Viola}

Tal como na passagem do candomblé para capoeira, passa-se do ciclo do Padre Cícero, de cunho devocional, para a temática guerreira do cangaço, cuja figura histórica e mítica principal é o personagem Lampião (A Arte da cantoria: Ciclo do Cangaço, faixa 2). Essas improvisações foram realizadas entre novembro de 1987 e junho de 1988, entre Recife, Olinda e Rio de Janeiro. O repente transposto a seguir corresponde à improvisação de versos sobre o mote "minha arma é a viola”, cujos dois cantadores pronunciam na última frase (cadência). A irregularidade métrica - cinco frases $a$ com variantes a cada repetição - deve-se à construção da improvisação com base nos Dez Pés à Quadrão, ou seja, a estrofe possui dez versos de 7 sílabas. Encontra-se no $2^{\circ}$ modo do gênero diatônico puro (dórico), apesar de o acorde executado pelas violas ser maior! Ou seja, o cantador sobrepõe a $3^{\mathrm{a}}$ menor do modo à $3^{\mathrm{a}}$ maior do acorde. Todas as frases concluem na tônica (1) e as semifrases no interior concluem interrogativamente ora na segunda (2), na sétima (7) e na quarta (4) nota do modo. As hastes inferiores correspondem a algumas variantes realizadas pelo $2^{\circ}$ cantador.

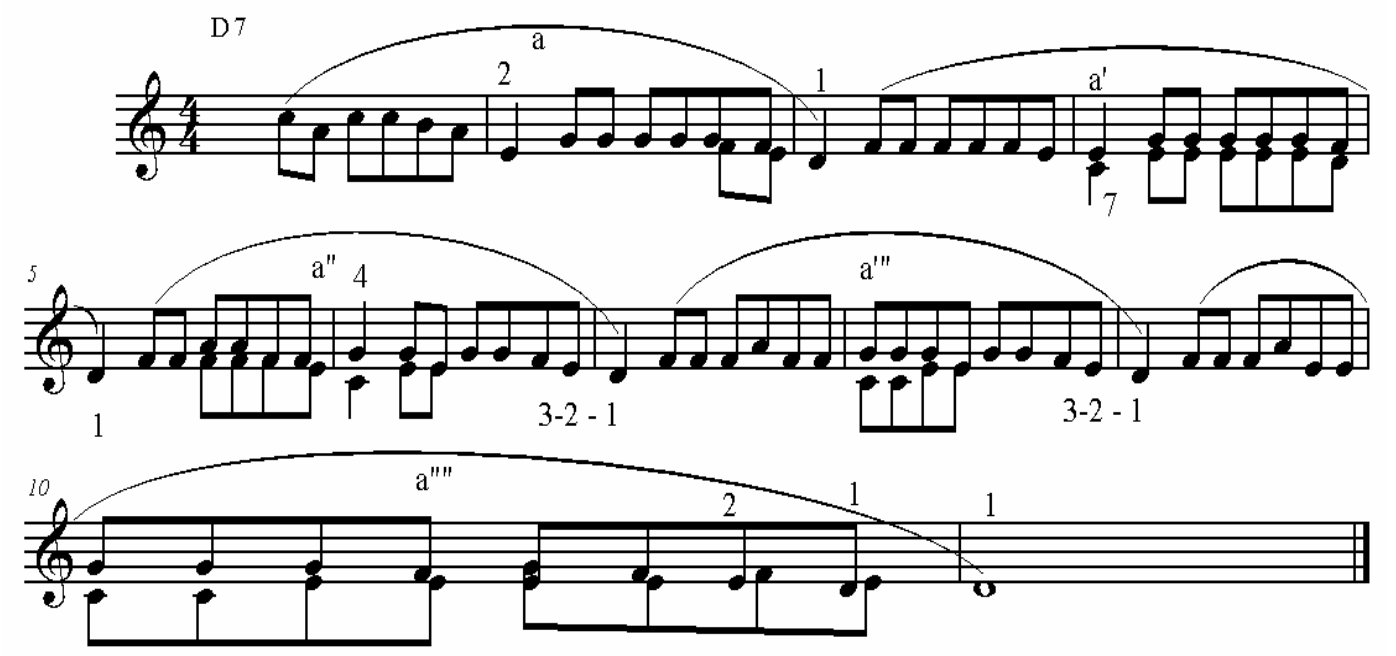

Fig.3.39 - Cantoria 6

\subsubsection{Lampião fez muita gente/ Abandonar o Sertão}

A próxima cantoria também se baseia no Dez Pés à Quadrão; é composto por frases $a$ interrogativas que se concluem na terça (3) e frases $b$ e $b$ ' que concluem afirmativamente na tônica (1) através da cadência 1+2-1. Há uma frase b’ extra, responsável pela irregularidade métrica, por sua vez ligada à estrutura poética. O modo é o do $4^{\circ}$ grau do gênero diatônico 
puro ou híbrido (ausência da $7^{\mathrm{a}}$, lídio ou mixolídio com $4^{\mathrm{a}}$ aumentada). A segunda hipótese parece corresponder mais à realidade em função de a viola executar um F7; entretanto, há uma curiosa cadência harmônica tonal - V(C7)- I - na última frase.

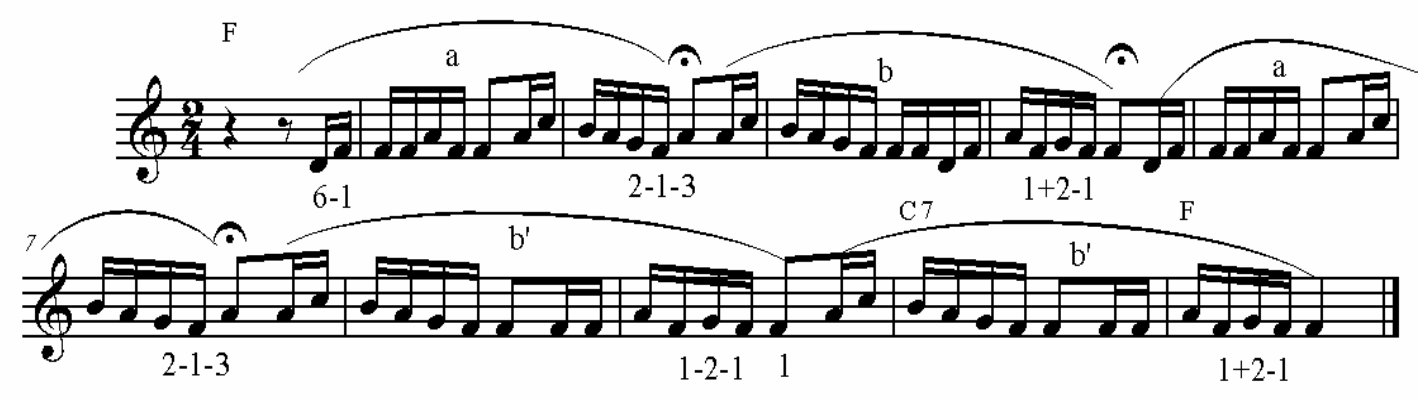

Fig.3.40 - Cantoria 7

Embora a cantoria seja um gênero sobre o qual Mario de Andrade não se debruçou, não deixa de ser interessante o seguinte testemunho do autor:

[...] é muito possível que nesses nordestinos a gente vá encontrar uma reprodução contemporânea da maneira de cantar dos rapsodos gregos ou do canto cristão primitivo. Com efeito se dá neles uma união absoluta da música e da palavra falada, de forma a tornar impossível uma fixação rítmicomusical isolada. É a maneira de falar, natural e despreocupada, que determina às vezes em absoluto a sucessão de sons da melodia. (ANDRADE, s/d, p. 140)

Nessa obra (Ensaio Sobre a Música Brasileira), há uma quase ausência total de melodias modais. Embora o autor não se restrinja a uma região específica do Brasil, dentro de um universo de 120 melodias, apenas nove são modais e todas elas provêm do Nordeste: Despedida, Olé Lioné e no modo do $5^{\circ}$ modo (mixolídio): Samba do Matuto, Recrutas Cearenses são exemplos híbridos entre o tom maior e o $5^{\circ}$ modo na primeira melodia e indefinido entre o $6^{\circ}$ e $2^{\circ}$ modo (eólio e lídio) do gênero diatônico puro ; O Cego no $4^{\circ}$ modo (lídio), Canto Antigo, Romance Sertanejo e Toada do Traiá no $6^{\circ}$ modo (eólio), além da famosa Mulher Rendeira no $1^{\circ}$ modo com cadência 6+1 sem sensível, atribuída então [1928] ao bando de Lampião.

\subsection{Considerações Parciais}

A partir dos dados selecionados, procura-se agora traçar um perfil de como o modalismo das melodias analisadas se dão, classificando-as pelos modos e traços cadenciais. A tabela a seguir classifica o gênero, o modo, o final do antecedente e do conseqüente. 
Embora fossem encontradas algumas estruturas ternárias (7) e irregulares (4) elas, via de regra, repetem o antecedente ou o conseqüente com algumas variações, sem que se alterem as principais cadências.

Portanto, tais melodias foram enquadradas no modelo de pergunta e resposta. O sinal de menos indica intervalo descendente e o sinal de mais, o ascendente. Antes que se adentre a Tabela 3.2, a figura 3.41 apresenta no pentagrama a primeira coluna da referida tabela correspondente ao gênero pentatônico:

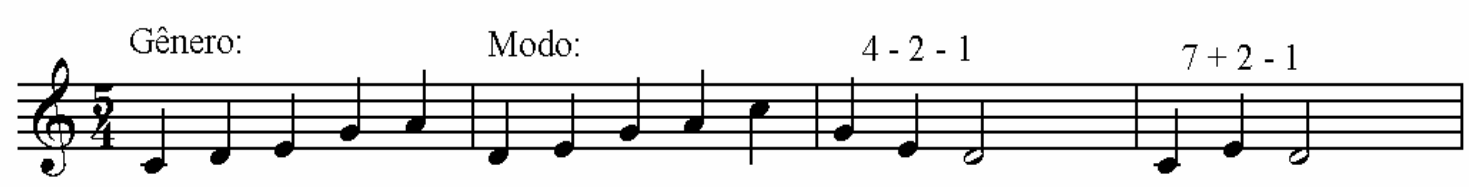

Fig.3.41 - primeira coluna da Tab. 3.2

Gênero Modo antecedente (pergunta) cadência (resposta)

\begin{tabular}{|l|c|c|c|}
\hline Pentatônico & 2 & $4-2-1$ & $7+2-1$ \\
\hline “ & 5 & $1-5$ & $5-3$ \\
\hline “ & 2 & $1-7$ & $5+7+1$ \\
\hline “ & 2 & $5+7+1$ & $5+7+1$ \\
\hline “ & 5 & $3-1$ & $3-7+1$ \\
\hline “ & 5 & $5+7$ & $3-7+1$ \\
\hline “ & 5 & & $5+7+1$ \\
\hline “ & 2 & $2+4$ & $7+2-1$ \\
\hline “ & 2 & $7-3$ & $7+2-1$ \\
\hline “ & 2 & $3+5+1$ & $7+2-1$ \\
\hline “ & 5 & $1+5$ & $4-1$ \\
\hline
\end{tabular}

Tab.3.2 Gênero Pentatônico.

Observa-se que, no repertório estudado, só se encontrou o uso do $1^{\circ}$ (maior), $2^{\circ}$ e do $5^{\circ}$ modo (menor) do gênero pentatônico. Das doze frases analisadas, apenas uma se resolve na terceira nota (3) do modo, o restante resolvendo na tônica (1). Dos onze antecedentes, quatro se resolveram na própria tônica (1), nos momentos em que o conseqüente faz resposta literal, duas vezes na $5^{\mathrm{a}}$, duas na $7^{\mathrm{a}}$ e na $3^{\mathrm{a}}$ e uma vez na $4^{\mathrm{a}}$. 
Do gênero diatônico maior, o mais utilizado em nesse trabalho foi o $5^{\circ}$ modo (mixolídio). A tabela 3 apresenta o perfil das quinze melodias no modo mixolídio:

Gênero Modo antecedente (pergunta) cadência (resposta)

\begin{tabular}{|l|c|c|c|}
\hline Diatônico puro & 5 & $4-3$ & 3 \\
\hline “ & 5 & $7-6-5$ & $5-6-5$ \\
\hline “ & 5 & $3-2-1$ & $3-2-1$ \\
\hline “ & 5 & $7-6-5$ & $7-6-5$ \\
\hline “ & 5 & 5 & $4-3$ \\
\hline “ & 5 & $3-1$ & $4-5$ \\
\hline “ & 5 & $6-5$ & $6+1$ \\
\hline “ & 5 & $5-3$ & $3-2-1$ \\
\hline “ & 5 & $1+3$ & $6+1$ \\
\hline “ & 5 & $1+3$ & $1+3+5$ \\
\hline “ & 5 & $5+7$ & $2-1$ \\
\hline “ & 5 & $5+7$ & $7-6-5$ \\
\hline “ & 5 & $1-7-5$ & $3-2-1$ \\
\hline
\end{tabular}

Tab.3.3 Quinto Modo do Gênero Diatônico.

* O parêntese indica a transposição da cadência quinta acima.

Observa-se aqui uma maior variedade de notas finais para os conseqüentes, embora tais notas sempre pertençam às notas da tríade básica do modo (tônica, $3^{\mathrm{a}}$ e $5^{\mathrm{a}}$ ). Já em relação ao conseqüente, as possibilidades aumentam, incluindo aí a resolução na $7^{\text {a }}$ (duas vezes), que se igualou ao número de resoluções na tônica (1). Houve cinco resoluções na $5^{\mathrm{a}}$ e cinco na $3^{\mathrm{a}}$, havendo uma resolução na $4^{\mathrm{a}}$ que, na verdade, trata-se de uma transposição do $5^{\circ}$ modo para o IV grau da escala original. O segundo modo mais utilizado do gênero diatônico foi o $6^{\circ}$, com seis linhas melódicas a ele pertencentes. 
Gênero

Modo

antecedente (pergunta) cadência (resposta)

\begin{tabular}{|c|c|c|c|}
\hline Diatônico puro & 6 & $3-2-1$ & $4-1$ \\
\hline " & 6 & $3-1$ & $3-1$ \\
\hline “" & 6 & $3-1$ & $3-1$ \\
\hline “ & 6 & $6+1$ & $6+1$ (maior) \\
\hline “ & 6 & $5-4-3$ & $3-2-1$ \\
\hline “ & 6 & $4+5$ & $1+2-1$ \\
\hline
\end{tabular}

Tab.3.4 Sexto Modo do Gênero Diatônico.

Neste caso, todas as finalizações se deram na tônica e os finais dos antecedentes na notas da tríade, havendo uma preponderância da tônica. O terceiro modo mais utilizado foi o $4^{\mathrm{o}}$, ou seja, o modo lídio.

Gênero

Modo antecedente (pergunta) cadência (resposta)

\begin{tabular}{|c|c|c|c|}
\hline Diatônico puro & 4 & $1+2+3$ & $6+7+1$ \\
\hline " & 4 & $3+4+5$ & $1+2-1$ \\
\hline " & 4 & $1-3$ & $4-2-1$ \\
\hline “ & 4 & $1+3-1$ & $2+3-1$ \\
\hline " & 4 & $1+3$ & $1+2-1$ \\
\hline
\end{tabular}

Tab.3.5 Quarto Modo do Gênero Diatônico.

O quarto modo apresentou todos os finais na tônica e os finais do antecedente na notas da tríade. $\mathrm{O}$ modo menos utilizado foi o $2^{\circ}$ (dórico). Apenas quatro melodias se encontraram nele.

Gênero Modo antecedente (pergunta) cadência (resposta)

\begin{tabular}{|l|c|c|c|}
\hline Diatônico puro & 2 & $4-1$ & $4-1$ \\
\hline “ & 2 & $4+5$ & $3-1$ \\
\hline “ & 2 & $3+5$ & $2+4-1$ \\
\hline “ & 2 & $3-2-1$ & $3-2-1$ \\
\hline
\end{tabular}

Tab.3.6 Segundo Modo do Gênero Diatônico.

Novamente todos os finais se dão na tônica e os antecedentes terminam na tônica ou na $5^{\mathrm{a}}$. 
O aspecto mais importante em relação a essas tabelas é o da leitura que se pode delas fazer. Parece muito óbvio que o final das respostas se dêem na tônica e das perguntas, em outros graus. Procura-se ressaltar que, dos gêneros diatônicos, só houve um final 7+1, ou seja, somente um final com sensível que, como se trata do $4^{\circ}$ modo, pode-se discutir sua natureza e característica. É somente no gênero pentatônico que se dá o uso da $7^{\mathrm{a}}$ na cadência, normalmente em forma de bordadura $(7+2-1)$. Também não houve nenhum final $5+1$, ou seja, o salto de quarta ascendente que realiza o movimento dominante-tônica do ponto de vista melódico. Destacam-se aqui os finais 6+1, bastante característicos, 4-1 e 3-2-1, que também foram transpostos em 7-6-5 e ocorreram em mais de um modo.

Outros aspectos também já eram esperados, como o fato de o gênero pentatônico ocorrer dentro de um contexto afro-brasileiro e o maior número de melodias no $5^{\circ}$ modo (mixolídio). Entretanto, causou estranheza o baixo número do uso do $2^{\circ}$ modo (dórico). Devese lembrar que tais melodias foram extraídas de um contexto maior, do qual uma série de exemplos tonais foi excluída. Mesmo em relação às citações da literatura de Mário de Andrade, nota-se que sempre há uma proporcionalidade em que os exemplos modais são a exceção e não a regra. É exatamente na cantoria, manifestação sobre a qual Mário não se debruçou tanto, que o contrário parece ocorrer: a predominância de exemplos modais sobre os tonais. Esses dados serão de extrema importância na averiguação futura de como os compositores populares construirão suas obras a partir desses matizes.

Em relação às diferentes manifestações culturais escolhidas, acredita-se que a cantoria se estabeleceu como o modelo da música nordestina para o sulista, e que, portanto, os seus traços serão os mais utilizados na construção de uma música de caráter regional. E, além disso, há uma contaminação entre os gêneros como demonstra o artigo de Maria Ignez Novais Ayala e Marinaldo José da Silva ${ }^{80}$ a respeito do uso das melodias de coco no culto da Jurema, ou seja, no catimbó. Nas diversas modalidades do coco também há aquele denominado cocode-embolada, nos quais as características de cantoria (improviso e desafio entre dois cantadores) se fazem presentes a ponto de, no sentido inverso ao da cantoria, que sai do folheto para o a cultura oral, ser transformado em cordel, como demonstra o artigo de Jimmy Vasconcelos de Azevedo ${ }^{81}$.

Outra importante manifestação cultural do Nordeste brasileiro é a das bandas de cabaçal ou de pífanos: um conjunto de percussão e sopro que toca marchas, galopes,

\footnotetext{
${ }^{80}$ Da brincadeira do coco à jurema sagrada: os cocos de roda e de gira. In Cocos: Alegria e Devoção, 2000, p.117-135.

${ }^{81}$ A Poesia dos Cocos. In Cocos: Alegria e Devoção. 2000, p.73-82.
} 
modinhas, rodas e valsa pelos sertões de Pernambuco, Paraíba e Ceará (ver Cascudo, 2002, p.85). Diversas bandas foram registradas na Missão, de Mário de Andrade (1938) e em sua recente visitação (2005). O problema aqui encontrado foi o da dificuldade da transcrição em função do não-temperamento do pífano. Na dissertação de mestrado de Pedrasse (2002) sobre a famosa Banda de Pífanos de Caruaru, encontram-se transcrições que, com o auxílio do computador, apontam para notas coma bemol ou sustenido. Em relação às escalas encontradas, o autor diz o seguinte, baseado em gravações comerciais:

Quanto às escalas percebemos um grande uso da escala diatônica maior, encontrada em quase metade das músicas analisadas. Essa ocorrência somada à utilização do modo menor harmônico e melódico denota forte influência da música tonal européia. A essas características mesclam-se as influências modais (modos dórico e mixolídio) que indicam um influxo do período pré-temperamento. (PEDRASSE, 2002, p.146)

É nesse contexto que se encontram o ritmo e canto do baião, que parece ter advindo da dança intitulada "baiano”, cuja música era executada entre os cabaçais. Entre os cantadores, o baião era a introdução instrumental dos desafios ${ }^{82}$, manifestação que embasou Luiz Gonzaga, levando-o a popularizar o gênero na esfera da comunicação de massa dos rádios, discos e, posteriormente, da televisão.

Um dado que nos interessa é o de que as Bandas de Cabaçal são eminentemente instrumentais, haja vista que, em todos os outros gêneros aqui estudados, há uma grande importância da letra e, portanto, da estrutura poética. Mesmo no caso do candomblé, é fácil verificar que, apesar de aqui não se ter chegado ao entendimento do texto em Iorubá, as mudanças de uma seção para outra após um determinado número de repetições se davam em função da mudança do texto. Inclusive, em razão disso, as peças dedicadas aos orixás foram aquelas que, dentro deste trabalho, tinham maior estruturação formal na medida em que possuíam às vezes até quatro seções encadeadas.

Como referido no início deste capítulo, as congadas mineiras pesquisadas não apresentaram traços modais e seu correspondente pernambucano, o Maracatu - também equivalente ao afoxé baiano ${ }^{83}$, ou seja, à apresentação pública do Candomblé - não apresenta os traços procurados. É somente no maracatu rural de Caruaru que o maestro Guerra-Peixe

\footnotetext{
${ }^{82}$ Ver Cascudo, 2002, p.41-42, e o depoimento em Pedrasse, 2002, p.44.

83 “Os Maracatus teriam sido outrora designados, em sua primeira fase, 'nações' e ‘afoxés'. Como 'nações', implicavam em relações administrativas subordinadas à instituição do Rei do Congo; como ‘afoxés’, exibiam-se principalmente nas festas de coroação de reis negros. [...] Com o nome 'Afoxé' há, na Bahia, uma folgança do gênero do cortejo recifense.” (GUERRA-PEIXE, 1956, p.29)
} 
encontrou alguns traços, mas que, ainda assim, podem ser interpretados como relações de dominantes secundárias.

Revelam os documentos do maracatu Cambinda Nova - da cidade de Caruaru - que duas melodias são hexacordais, três tonais, no modo maior clássico, e duas dependem de interpretação musicológicas, pois estas têm o sétimo grau rebaixado, que, pelo seu aspecto singular, tanto pode ser considerado como som natural da escala ou como alteração, provocando modulação à subdominante. (GUERRA-PEIXE, 1956, p.120)

Apenas vale ressaltar que, neste trabalho, foram consideradas melodias baseadas do pentacórdio ou no hexacórdio como subgrupos dos gêneros diatônicos, sendo, na maioria dos casos, classificadas como tonais, a não ser que apresentem algum traço específico, como, por exemplo, o $6+1$. 


\section{Luiz Gonzaga e Jackson do Pandeiro: Os Mensageiros do Norte}

Quando se pensa nas referências etnográficas que os compositores da década de 1960 tiveram para fazer suas canções com o aspecto regionalista mencionado aliado à temática social, é muito provável que certas manifestações, mais propriamente de massa ainda ligadas a tradições populares, formassem uma espécie de ponte entre esses dois universos: o da canção popular dos anos sessenta do século passado e o da música étnica.

É exatamente essa característica que possuem os presentes autores que trará as manifestações antes étnicas e folclóricas do Nordeste brasileiro ao campo propriamente da música popular urbana, adaptada aos gostos da classe média e baixa, principalmente no eixo Rio-São Paulo ao final da década de 40 e início dos anos 50 do século XX.

Luiz Gonzaga do Nascimento (1912-1989) era pernambucano, natural de Exu, e foi, segundo José Ramos Tinhorão, o principal responsável, juntamente com o letrista Humberto Teixeira, pela popularização do gênero do Baião.

O ritmo do baião nordestino, transformado em gênero de música popular urbana a partir dos meados da década de 40, graças ao trabalho do acordionista pernambucano Luis Gonzaga e do advogado cearense Humberto Teixeira. O balanceio [...] era uma adaptação do balanço rítmico da música de dança produzida pelos conjuntos de zabumba, sanfona, pífanos e do triângulo nordestino. (TINHORÃO, s/d, p.211)

É importante notar aqui que o aparecimento desse personagem na música popular se dá no Rio de Janeiro, ou seja, fora de seu habitat natural. Luiz Gonzaga foi tentar a sorte no programa de calouros de Ary Barroso no rádio, no início da referida década. Seu sucesso se deu somente quando começou a interpretar músicas oriundas de sua terra natal. A partir de então passa a vestir trajes característicos e a fazer sucesso, tornando-se o primeiro porta-voz do povo nordestino nos estados do Sudeste.

Esse é um dado relevante porque mostra o reconhecimento de um tipo de artista que se dá quando se torna famoso no centro econômico-cultural da época como representante do exótico da periferia (Nordeste), e aí o elemento modal se torna bastante característico e importante. Por outro, o gênero também sofrerá, posteriormente, algum preconceito advindo de vertentes da bossa nova e da elite do eixo Rio-São Paulo. ${ }^{84}$ Muitos músicos, como Edu

\footnotetext{
${ }^{84}$ Um exemplo disso encontra-se no fato de que a obra Panorama da Música Popular Brasileira, escrita na década de 1960, nem sequer mencionar nossos autores Vasconcelos, Ary. Panorama da Música Popular Brasileira. São Paulo: Ed. Martins Fontes, s/d. O reconhecimento da época se deu pelos anos abordados pelo autor, terminando em 1964.
} 
Lobo e João Donato, tiveram sua iniciação musical através da sanfona, instrumento em voga nas décadas de 1940 e 1950 devido ao sucesso dos autores abordados, que abandonam em seguida em favor do violão. Segundo o crítico Tárik de Souza ${ }^{85}$, o compositor Geraldo Vandré foi um dos responsáveis pela revalorização do compositor pernambucano na década de 1960, coisa que também fará a Tropicália, de Gilberto Gil e Caetano Veloso, na década seguinte, com Jackson do Pandeiro, através das releituras de suas obras.

Jackson do Pandeiro (José Gomes Filho, 1919-1982) aparece na década de 1950 como representante do gênero do coco. Integrou a antológica Orquestra Tabajara nos anos 1940 na Paraíba, uma Big Band que atua até hoje na direção do clarinetista Severino Araújo, vindo a conhecer músicos como Moacir Santos, K-Ximbinho, entre outros. Posteriormente em Recife, na orquestra da Rádio Jornal do Comércio, Jackson conheceu o então iniciante Hermeto Pascoal, chegando a aconselhá-lo profissionalmente. Diferentemente de Gonzaga, primeiramente faz sucesso regional para depois descer ao eixo Rio-São Paulo. Embora não seja diretamente o autor das canções escolhidas, é a partir do seu sucesso e de sua interpretação que elas se tornaram referenciais. Segundo os biógrafos Fernando Moura e Antônio Vicente (2001), Jackson não assinou nenhuma autoria até 1957, quando foi criada a UBC-União Brasileira de Compositores, muito embora tenha sido autor e co-autor de diversas canções por ele gravadas no processo de elaboração das interpretações. ${ }^{86}$

Numa fase em que ainda reinava o baião de Luiz Gonzaga, em 1953, ele começou a estourar sucessos mostrando uma outra face da música nordestina. O coco e o rojão, próximos ao ritmo do samba ganharam espaço nas rádios do sudeste a partir de clássicos como Sebastiana de Rosil [...] (SOUZA, 2000, p.118)

O que se pretende investigar aqui é, além de apontar a permanência das constâncias apontadas no capítulo anterior, como exatamente se deu essa adaptação ao gosto sulista dos elementos característicos daquela música.

\subsection{Juazeiro (Luiz Gonzaga e Humberto Teixeira)}

Lançada originalmente em $1949^{87}$, essa canção expõe um diálogo entre o eu-lírico e uma árvore (Juá), a qual teria sido testemunha de um amor, agora terminado.

\footnotetext{
${ }^{85}$ Depoimento para o VDV Vento Bravo. Lobo, 2007.

${ }^{86}$ Ver MOURA, 2001, p. 228.

${ }^{87}$ RCA-Victor 80.0608-a.
} 
A melodia encontra-se no $5^{\circ}$ modo (mixolídio), frases interrogativas $a$ e $b$ que se cadenciam na $3^{\text {a }}$ (3) respondidas pelas frases afirmativas $a^{\prime}$ e $b^{\prime}$ que cadenciam na tônica (1). O traço 6+1 aparece nas frases finais. Há uma harmonização baseada nas três funções principais que tonaliza a melodia, principalmente nos pontos cadenciais. Pode se dizer que se trata de uma sentença; entretanto, é preciso ponderar se tal termo, advindo de uma sistematização fraseológica do tonalismo, é adequado para melodias modais.
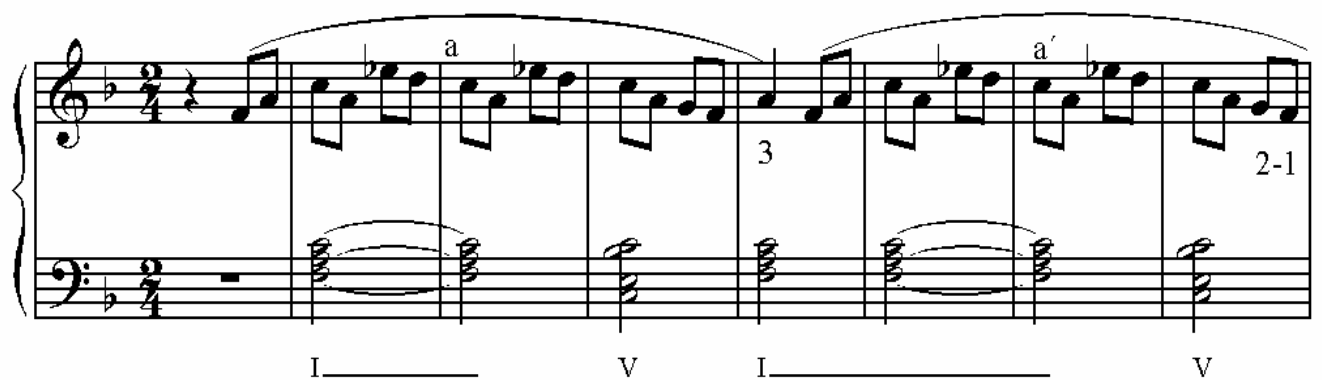

I

V

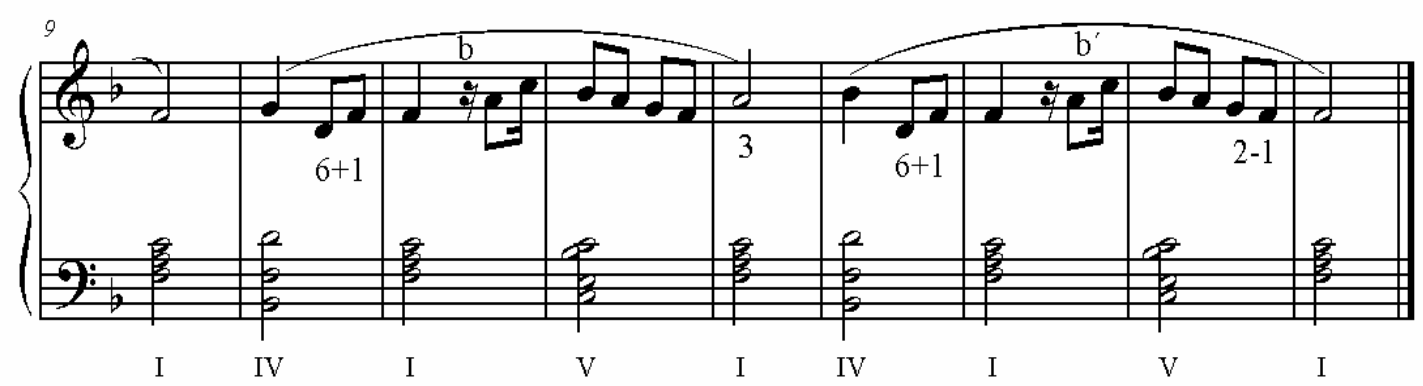

Fig.4.1 Juazeiro: melodia

A parte cantada desse baião é inteiramente baseada nas frases anteriores. Há ainda um refrão instrumental, também baseado no $5^{\circ}$ modo do gênero diatônico puro (mixolídio), com a intervenção pontual da sensível $m i$ na frase $a$. Além da cadência V-I, há o uso da dominante secundária V/II-II, ampliando a utilização dos recursos do tonalismo sobre a melodia. 


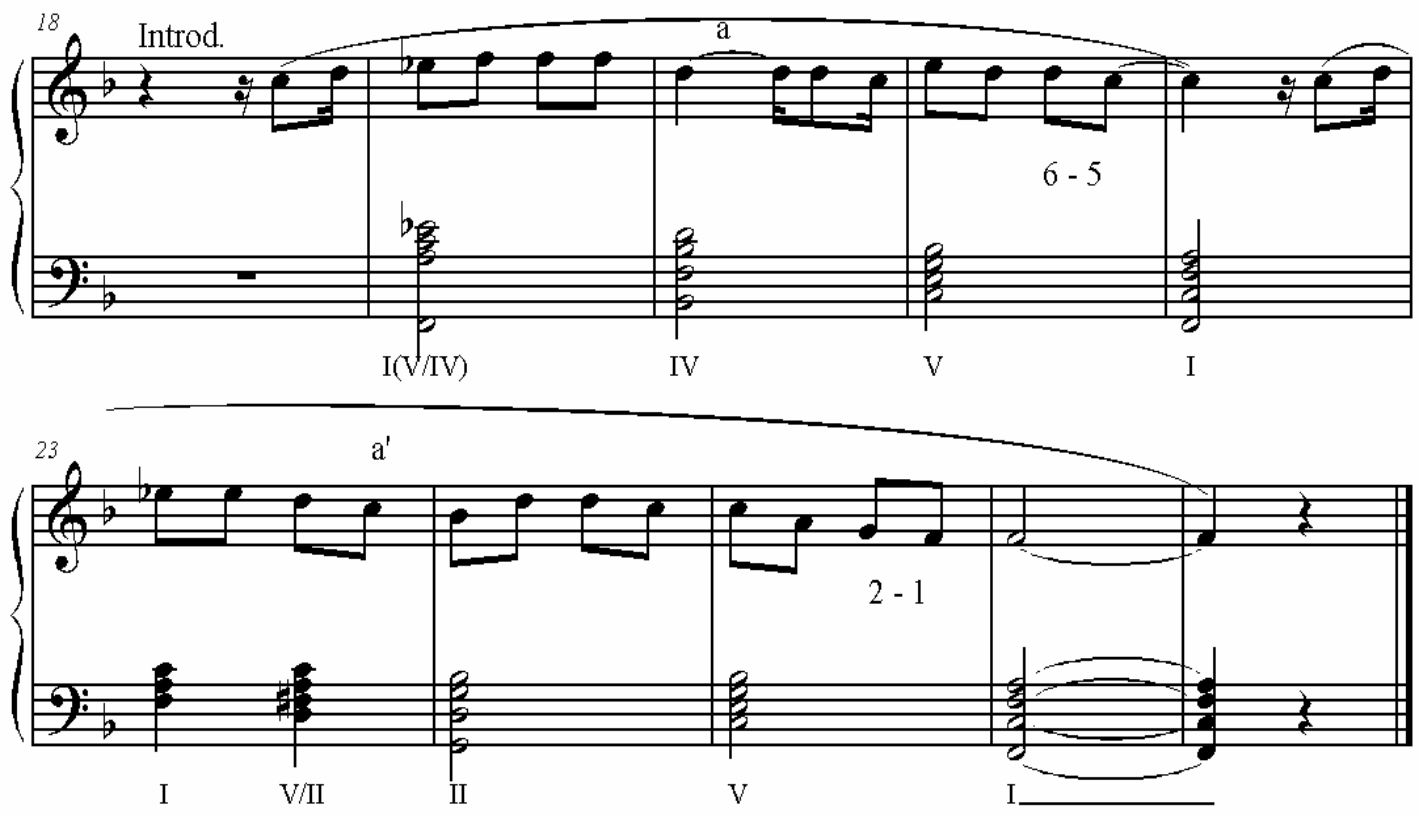

Fig 4.2 Juazeiro: refrão instrumental

E há uma coda que enfatiza o traço melódico 6+1, traço visto em diversos exemplos étnicos citados no capítulo anterior, aqui harmonizado com a cadência plagal IV-I.

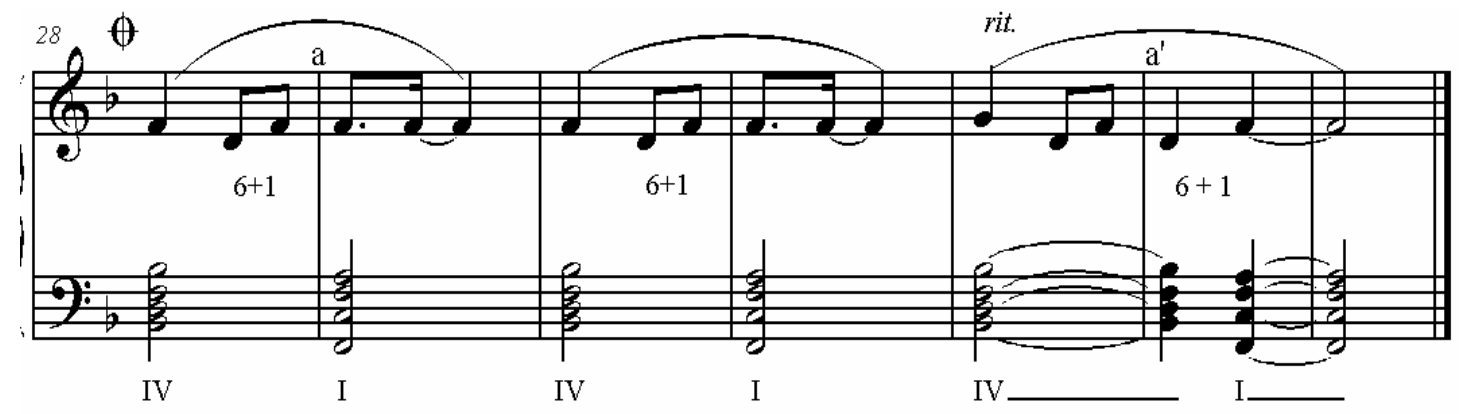

Fig.4.3 Juazeiro: coda

O arranjo desses elementos musicais se dá da seguinte maneira:

Introd.: //: Refrão Instrumental - Frases $a, a^{\prime}, b$ e $b^{\prime}: / / 4 x$ com letras diferentes e coda.

Do ponto de vista poético, há o uso alternado de versos de sete e quatro sílabas, com rima sempre nos versos ímpares, dentro de duas quadras. A tabela a seguir apresenta a relação entre a métrica, a rima, a fraseologia e a cadência melódica; o negrito apresenta os versos 
cantados pelo coro $^{88}$. Observa-se que, neste caso, o verso corresponde à semifrase. Portanto, as duas quadras compõem a estrutura binária da sentença.

M R Fraseologia

cad. melódica

\begin{tabular}{|c|c|c|c|c|c|}
\hline Juazeiro, juazeiro & 7 & $a$ & Semifrase 1 & Frase $a$ & \\
\hline Me aresponda por favor & 7 & $b$ & Semifrase 2 & ‘ & $1+3$ \\
\hline Juazeiro velho amigo & 7 & $c$ & Semifrase 1 & Frase $a$ ’ & \\
\hline Onde anda o meu amor & 7 & $b$ & Semifrase 2’ & ‘ & $2-1$ \\
\hline Ai juazeiro & 4 & $a$ & Semifrase 3 & Frase $b$ & \\
\hline Ela nunca mais voltou & 7 & $d$ & Semifrase 4 & ‘ & $1+3$ \\
\hline Viu juazeiro & 4 & $a$ & Semifrase 3’ & Frase $b$ ’ & \\
\hline Onde anda o meu amor? & 7 & $b$ & Semifrase 4’ & ‘ & $2-1$ \\
\hline
\end{tabular}

Tab. 4.1 Juazeiro

A preferência pela redondilha maior pode ser atribuída à tradição dos cantadores, já que é muito comum o uso dessa métrica nos padrões do repente como os Oito Pés à Quadrão e Quadrão Alagoano, Mineiros, etc. É importante ressaltar que tais menções não dizem respeito às regiões mencionadas, mais ao tipo de rima (“ão”, “eiro”, “ano”, etc.). ${ }^{89}$

\subsection{Baião (Luiz Gonzaga e Humberto Teixeira)}

Trata-se da canção que lança o gênero de música e dança na condição de moda no final da década de $1940 .^{90}$ A melodia da seção A encontra-se também no $5^{\circ}$ modo (mixolídio); entretanto, quando há a mudança harmônica para o IV grau, este também vem com a $7^{\text {a }}$ menor, resultando, assim, em uma transposição do mesmo modo uma $4^{\mathrm{a}}$ justa abaixo. Trata-se de uma sentença que apresenta uma curiosa cadência harmônica na frase cadencial: VIIb - V - I, sendo todos acordes maiores com $7^{\mathrm{a}}$ menor, ou seja, todos da tipologia dominante mas apenas o da relação V-I exercendo a função de Dominante, quer dizer, tonalizando o final da seção. Esta seção também é apresentada pela sanfona, indicada pelas notas inferiores da melodia, apresentando a maneira como ela ficou mais conhecida.

\footnotetext{
${ }^{88}$ Em todos os exemplos deste trabalho, a escansão é realizada a partir da interpretação realizada na gravação de referência.

${ }^{89}$ Zé Francisco \& Palmeirinha da Bahia. Literatura de Cordel, Repentistas e Cantadores. São Paulo: Meridional Ed. Limitadas, 1977.

${ }^{90}$ RCA-Victor 800605b, 1949.
} 

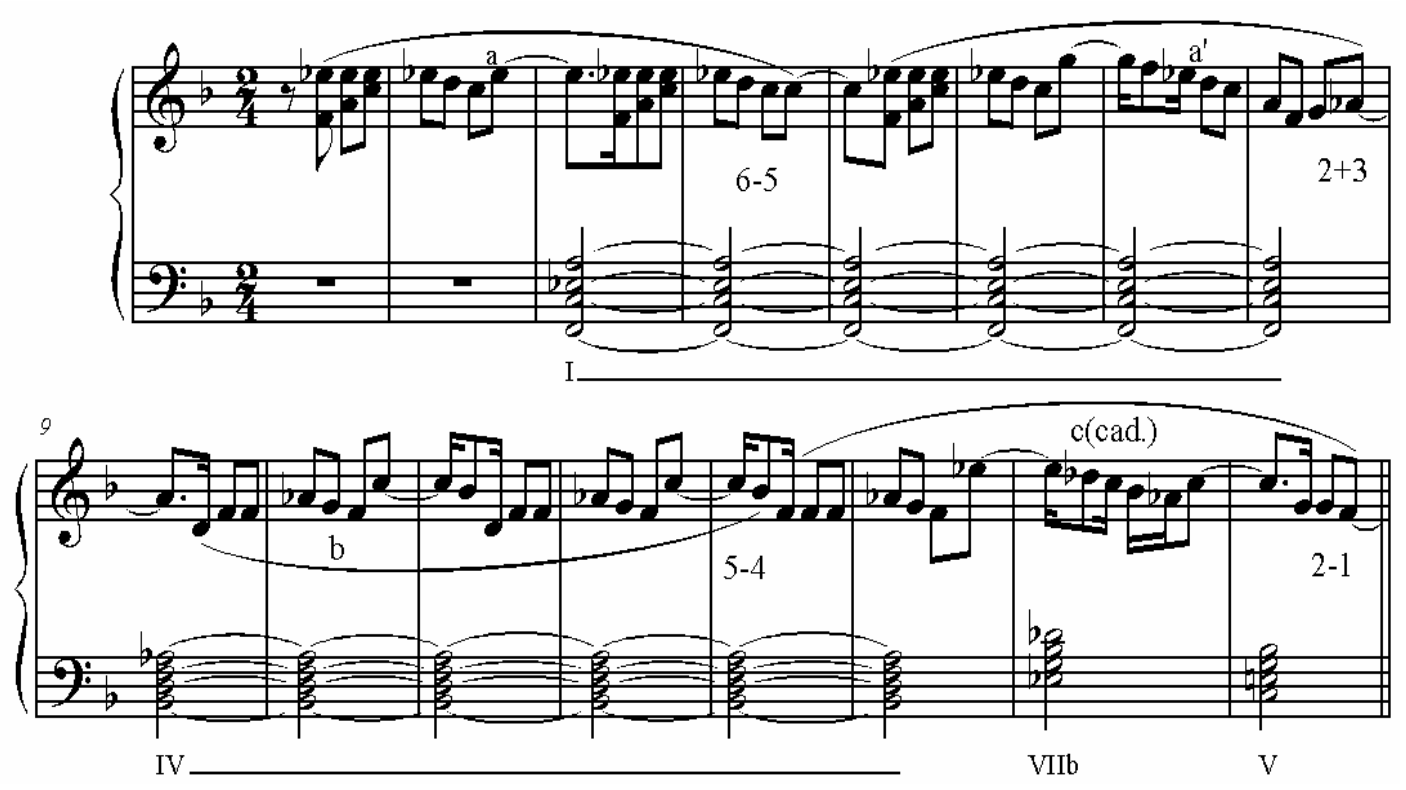

Fig. 4.4 Baião: seção A.

Entre as seções A e B há uma pequena ponte de sete compassos que enfatiza a tônica (I) e o ritmo. A seção seguinte apresenta uma nova melodia no $5^{\circ}$ modo (mixolídio) agora no IV grau, sempre com $7^{\mathrm{a}}$ menor. Em um primeiro momento se tem a impressão de que se está em uma nova tonalidade. Entretanto, a cadência é a mesma da seção anterior, concluindo esta seção na tonalidade original. A estrutura é praticamente idêntica à da seção anterior, excetuando-se pelo fato de que a frase $b$ é de menor extensão, gerando uma irregularidade fraseológica que resulta em uma seção de catorze em vez de dezesseis compassos, ou seja, uma estrutura binária irregular. Os finais de frases se dão em transposições, conforme indica o parêntese, ou seja, o final 1+3 é, na relação com a harmonia, um 5+7, final suspensivo na $7^{\text {a }}$ menor. 

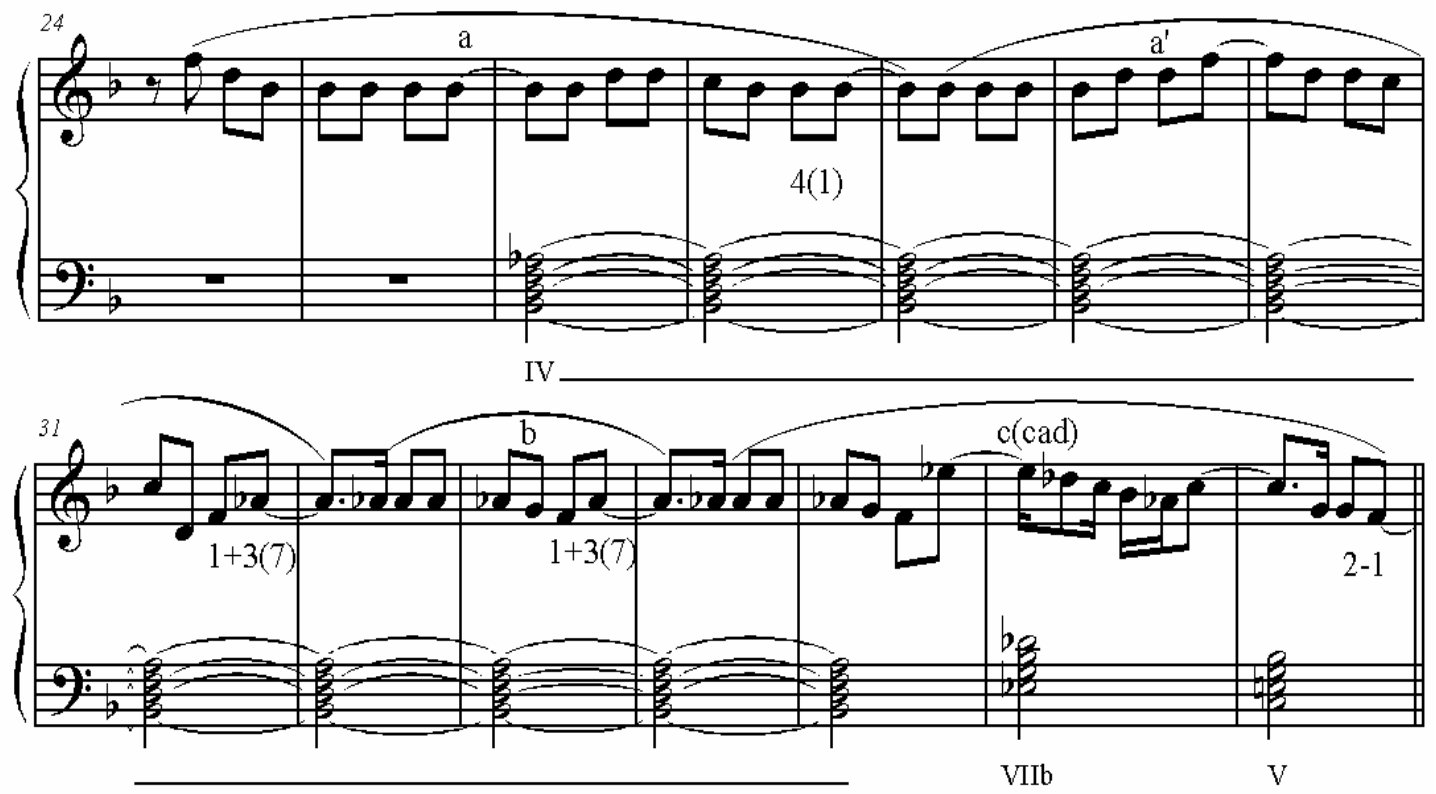

Fig. 4.5 Baião: seção B.

Após a seção B, há também uma pequena extensão de sete compassos que enfatiza os mesmos aspectos referidos na ponte. Trata-se de uma função similar à do vamp, aqui num único acorde, que estabelece a modalidade - F7, $5^{\circ}$ modo - e o elemento rítmico característico: o baião. Comparando esses dois elementos, verifica-se que eles são praticamente o mesmo, com algumas variações melódicas.

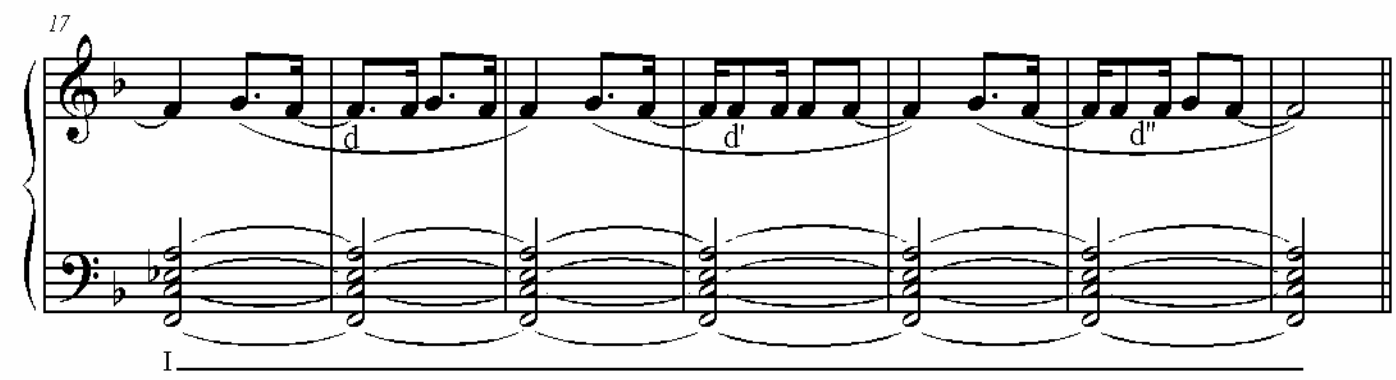

Fig. 4.6 Baião: ponte

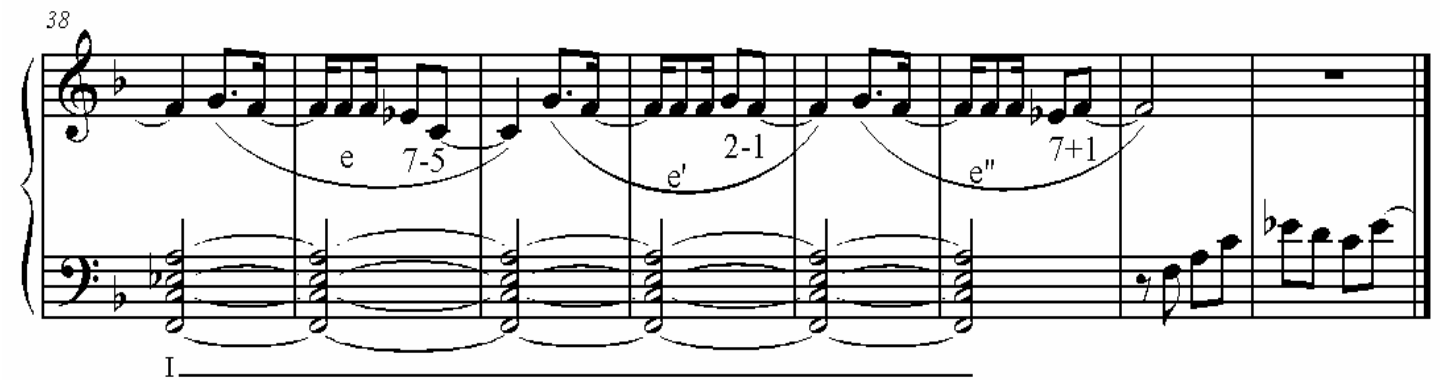

Fig. 4.7 Baião: codeta da seção B

Nesta gravação de referência (1949), o arranjo se dá da seguinte maneira: 
Introd. A (instrumental); A (cantado); ponte; B codeta; A (instrumental) cod.;

B cod. (fade out).

A letra de Humberto Teixeira aponta para o largo uso da redondilha maior, muito popular entre os repentistas e, aqui, com o uso da rima “ão", muito própria ao quadrão. Observa-se que a quebra do uso do verso de sete sílabas se dá no momento de alteração da semifrase e da frase cadencial.

M R Fraseologia

Cad. Melódica

\begin{tabular}{|l|l|l|l|l|l|}
\hline Eu vou mostrar pra vocês & 7 & $a$ & semifrase 1 & Frase $a$ & \\
\hline como se dança o baião & 7 & $b$ & semifrase 1’ & “ “ & $6-5$ \\
\hline E quem quiser aprender & 7 & $c$ & semifrase 1” & Frase $a$ ’ & \\
\hline é favor prestar atenção & 8 & $b$ & semifrase 2 & “ “ & $2+3$ \\
\hline Morena chegue pra cá & 7 & $d$ & semifrase 1”’ & Frase $b$ & \\
\hline bem junto ao meu coração & 7 & $b$ & semifrase 1”’ & “ “ & $5-4$ \\
\hline Agora é só me seguir & 7 & $e$ & semifrase 3 & Frase $c$ & \\
\hline pois eu vou dançar o baião & 8 & $b$ & semifrase 4 & Cad. & $2-1$ \\
\hline
\end{tabular}

Tab. 4.2 Baião seção A

Já a seção B apresenta um número incomum de sete versos que é correspondente à irregularidade métrica da sentença irregular apresentada na análise fraseológica.

M R Fraseologia

Cad.

\begin{tabular}{|l|c|l|l|l|l|}
\hline Eu já dancei balancei & 7 & $a$ & Semifrase 1 & Frase $a$ & \\
\hline chamego, samba e xerém, & 7 & $b$ & Semifrase 2 & “ “ & $4(1)$ \\
\hline Mas o baião tem um quê & 7 & $c$ & Semifrase 1’ & Frase $a$ ’ & \\
\hline que as outras danças não tem, & 7 & $b$ & Semifrase 2’ & “ “ & $1+3(7)$ \\
\hline E quem quiser só dizer, & 7 & $d$ & & Frase $b$ & $1+3(7)$ \\
\hline pois eu com satisfação, & 7 & $e$ & semifrase 3 & Frase $c$ & \\
\hline vou dançar cantando o baião & 8 & $e$ & semifrase 4 & (cad.) & $2-1$ \\
\hline
\end{tabular}

Tab. 4.3 Baião: seção B. 


\subsection{Vem, Morena (Luiz Gonzaga e José Dantas)}

Quando se observa a lista das gravações realizadas por Luiz Gonzaga ${ }^{91}$, constata-se que o gênero baião só se apresentou a partir da gravação das canções analisadas aqui, que constavam do mesmo compacto. Mesmo a antológica Asa Branca, cuja primeira gravação remonta ao ano de 1947, ficou registrada como do ritmo toada, juntamente com choros, mazurcas, quadrilhas, valsas, polcas, “xamegos”, ${ }^{\text {, }}$, emboladas, marchas, sambas, frevos e o xote. $^{93}$

A canção aqui focada traz um dos raros e, no entanto, significativos exemplos do uso do $2^{\circ}$ modo (dórico) do gênero diatônico ${ }^{94}$. Observa-se que os dezesseis primeiros compassos formam uma estrutura binária sem cadência (sentença?) pelas frases $a, b$ e derivações com finais 3-1 e 2-1 (afirmativos) e 1+3 (interrogativo). O traço melódico 6+1 aparece nas frases b. Os treze compassos seguintes (os compassos 31 e 32 já fazem parte da repetição) condensam, em uma estrutura ternária irregular, as frases $a$ ”, $b$ ” e $c$ que corresponda à cadência.

\footnotetext{
${ }^{91}$ DREYFUS, 1996. p. 318-349.

92 “[...] como se não fosse suficiente, ainda inventava, sem dar a mínima satisfação à gravadora, um gênero musical. Pois a verdade é que o xamego nunca existiu enquanto gênero musical, e, ainda hoje, não está registrado em lugar nenhum, sequer na memória popular.” (DREYFUS, 1996, p. 89)

${ }_{93}$ Registrado pela primeira vez em 1946 na canção No Meu Pé de Serra (Luiz Gonzaga e Humberto Teixeira) RCA Victor 800495b. A letra faz menção ao ritmo, mas a canção é completamente tonal.

${ }^{94}$ RCA Victor: $800643^{\mathrm{a}}$, 1949. Segundo Cascudo (2002, p.623), o ritmo é um derivado do schottishe, dança de salão européia que entrou no Brasil no século XIX.
} 


\section{Vem Morena}

Luiz Gonzaga \& Zé Dantas
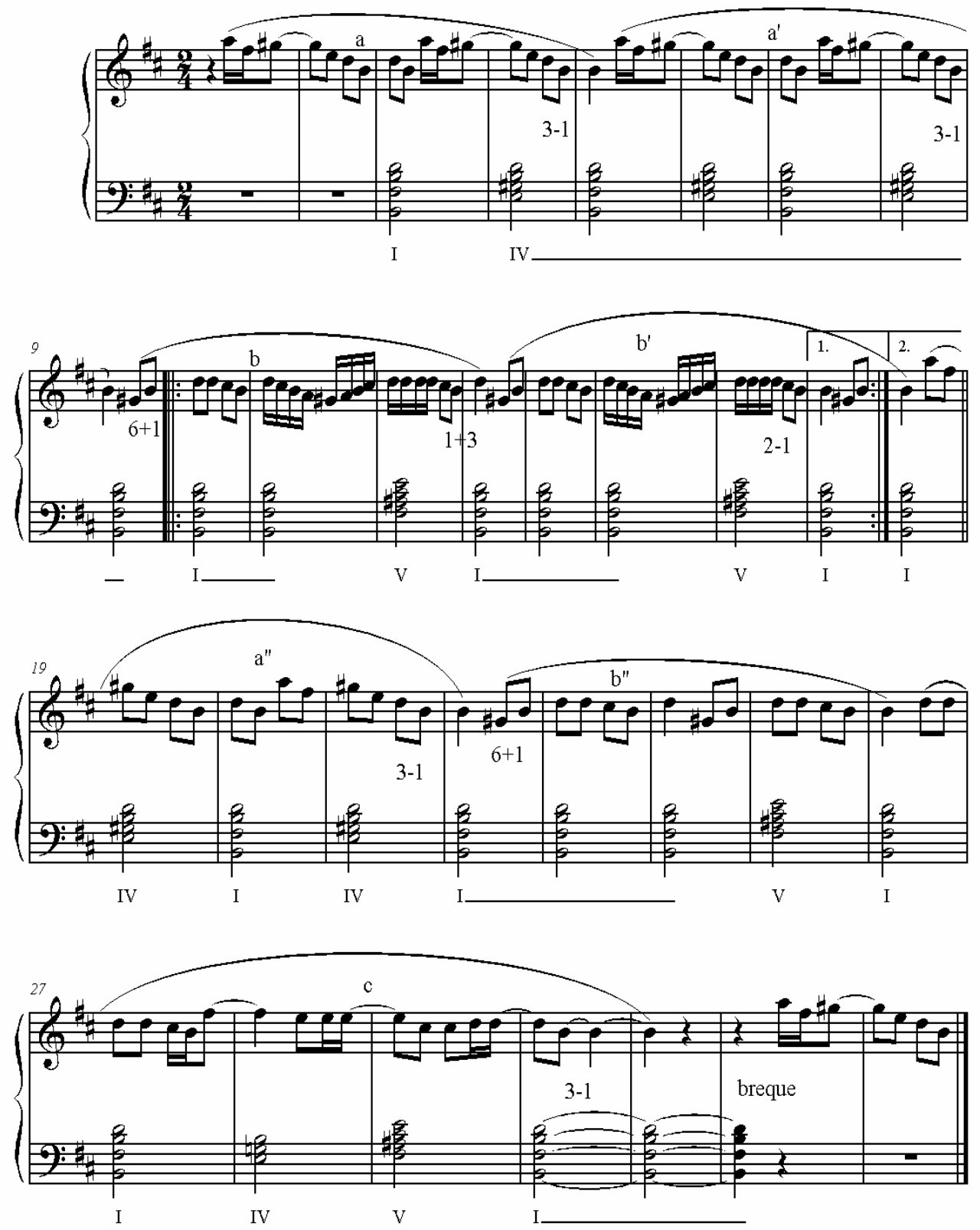

Fig. 4.8 Vem, Morena.

O dado relevante advém do fato de a harmonização das frases $a$ da canção se assentar na seqüência, hoje denominada vamp ${ }^{95}$, Im7-IV7, que caracteriza o modo dórico por priorizar o acorde menor sem a função de dominante exercida pelo V grau, ou seja, embora o IV grau

\footnotetext{
${ }^{95}$ Essa expressão será mais bem esclarecida no capítulo dedicado aos compositores dos anos 1960.
} 
seja aqui da tipologia dominante, não exerce tal função. Mas é nas frases $b$ e na frase cadencial $c$ que se dá uma cadência tonal (I-V-I e IV-V-I) advinda da relação antes evitada, como se a estilização ou a adaptação aos gostos do meio de comunicação da época tivesse que passar por tal cadência.

É importante ressaltar que a seqüência modal mencionada (vamp) foi amplamente usada em composições do alagoano Hermeto Pascoal, como em Forró Brasil, Viva Jackson do Pandeiro e como ponto de partida do baião Vale da Ribeira, por exemplo.

Os elementos dessa canção se arranjam da seguinte maneira:

Introd. Frases $a a^{\prime} b b^{\prime}$ instrumental

Voz: frases $a a^{\prime} b b^{\prime} b b^{\prime} a$ " $b^{\prime \prime} c$ breque

$$
\begin{gathered}
a a^{\prime} b b^{\prime} b b^{\prime} a^{\prime \prime} b^{\prime \prime} c \text { breque } \\
a a^{\prime} b b^{\prime} b b^{\prime}
\end{gathered}
$$

Interlúdio: frases $a a^{\prime} b b^{\prime}$ Instrumental breque

Voz: frases $a$ ” $b$ " $c$ breque

$a a^{\prime} b$ b’ várias vezes em fade out

A tabela abaixo apresenta a relação da letra com a música quando da primeira vez que a música é tocada. Após o interlúdio instrumental, a letra difere nas frases $a$ ”, $b$ ” e $c$.

A primeira quadra corresponde às frases $a$ e $a^{\prime}$ que, juntas, completam oito compassos e todos os versos têm sete sílabas.

M R Fraseologia

Cad.

\begin{tabular}{|l|l|l|l|l|l|}
\hline Vem, morena, pros meus braços & 7 & $a$ & Semifrase 1 & Frase $a$ & \\
\hline Vem, morena, vem dançar & 7 & $b$ & Semifrase 1’ & “ “ & $3-1$ \\
\hline Quero ver tu requebrando & 7 & $c$ & Semifrase 1 & Frase $a$ & \\
\hline Quero ver tu requebrar & 7 & $b$ & Semifrase 1’ & “ & \\
\hline
\end{tabular}

Tab.4.4 Vem, Morena: primeira quadra.

A segunda quadra compõe as frases $b$ e $b^{\prime}$. A diferença é que, ao invés de se escrever uma nova letra para a segunda frase $b$,' há a repetição do coro em responsório. Aqui a métrica do segundo verso é alterada pelo grande número de notas da semifrase 3. 
M R Fraseologia

Cad.

\begin{tabular}{|l|l|l|l|l|l|}
\hline Quero ver tu remexendo & 7 & $d$ & Semifrase 2 & Frase $b$ & \\
\hline Resfulego da sanfona inté o sol raiar & 13 & $b$ & Semifrase 3 & “ “ & $1+3$ \\
\hline Quero ver tu remexendo & & & Semifrase 2 & Frase $b$ ' & \\
\hline Resfulego da sanfona inté o sol raiar & & & Semifrase 3’ & “ “ “ & $2-1$ \\
\hline
\end{tabular}

Tab.4.4 Vem, Morena: frase $b$.

Os próximos versos se estruturam em sextilhas para se encaixarem na estrutura ternária irregular das frases $a, b$ ” e $c$ e retorna-se à métrica original (redondilha maior).

M R Fraseologia

Cad.

\begin{tabular}{|l|l|l|l|l|l|}
\hline Esse teu fungado quente & 7 & $a$ & Semifrase 1” & Frase $a$ ” & \\
\hline Bem no pé do meu pescoço & 7 & $b$ & Semifrase 1”’ & “ “ & $3-1$ \\
\hline Arrepia o corpo da gente & 7 & $a$ & Semifrase 2’ & Frase b” & \\
\hline Faz o véio ficar moço & 7 & $b$ & Semifrase 2” & “ “ & $2-1$ \\
\hline$\underline{\text { E o coração de repente }}$ & 7 & $a$ & & Frase $c$ & \\
\hline Bota o sangue em arvoroço & 7 & $b$ & & Cadência & 3-1 \\
\hline
\end{tabular}

Tab.4.5 Vem, Morena: sextilha final.

Um detalhe que pode ser observado é o intervalo cadencial 3-1 poder se hamonizar tanto modal (frases $a$ e derivadas), quanto tonalmente (frase $c$ ). Como as frases não se estruturam tonalmente, é mais difícil delimitar as seções como se as frases $a$ e $a^{\prime} b$ e $b^{\prime}$ formassem uma seção A, e as frases $a$ ”, $b$ ” e $c$ uma seção A' . Talvez, exatamente pelo modalismo melódico e pela ausência de região de contraste.

\subsection{7 na Corrente (Edgard Ferreira e Manoel F. Alves)}

Lançada em $1954^{96}$ em compacto simples e, posteriormente, no $2^{\circ}$ long playing de 1956, intitulado Forró do Jackson" ${ }^{97}$, está rotulada como “rojão"98. Recentemente gravada por Gilberto Gil (Gil, 1997), cujo álbum, além de canções tradicionais, também apresenta versões de cocos retirados de Andrade (2002).

\footnotetext{
${ }^{96}$ Rio de Janeiro: Copacabana, No 5287-A.

${ }^{97}$ Rio de Janeiro: Copacabana, CLP 3068.

${ }^{98}$ Segundo Cascudo (2002:589), trata-se de "um pequeno trecho musical, tocado na viola ou rabeca [...] antes do verso cantado do cantador.” É, portanto, um sinônimo de baião.
} 
É basicamente composta no $5^{\circ}$ modo diatônico puro (mi mixolídio). Todos acordes são da tipologia dominante no I, IV e V grau, apenas o último exercendo tal função. Trata-se, mais uma vez, de um grande híbrido entre tonal e modal, mas principalmente de uma harmonização que cadencia tonalmente uma melodia modal.

As frases $a$ e $a$ ' formam o refrão e a frase $b$ as estrofes. A frase $a$ ” apresenta a última estrofe para a entrega do refrão. 


\section{7 na Corrente}
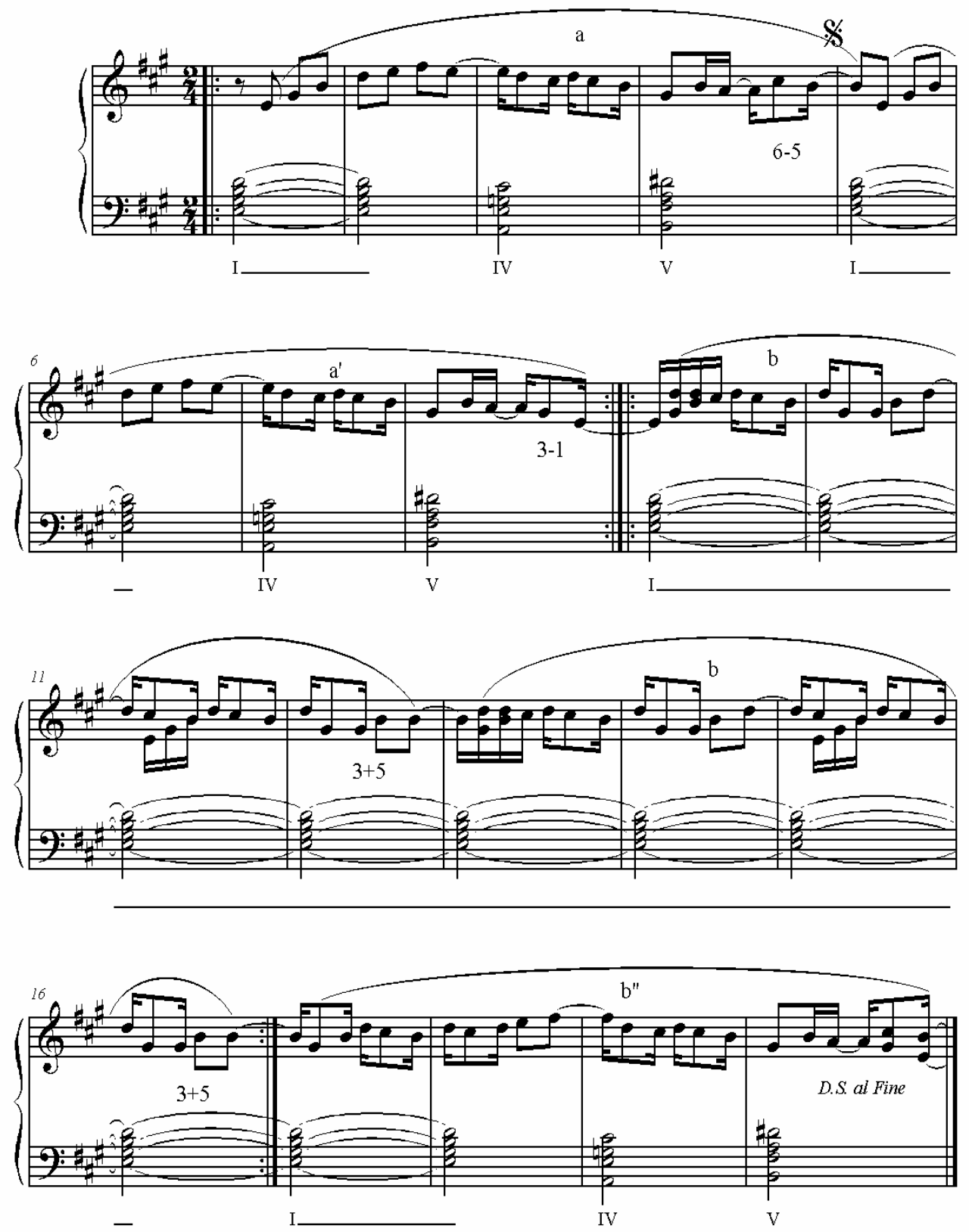

Fig. 4.817 na Corrente.

Os elementos dessa canção se arranjam alternando entre estrofe e refrão, diferindo de letra a cada estrofe: 
Introd. (frase $a$ instrumental)

Refrão (frases $a$ e $a^{\prime}$ )

Estrofe 1(frase $b-4 \mathrm{x}$ - e $a$ ”)

Refrão

Estrofe 2 (frase $b-2 \mathrm{x}$ - e $a^{\prime}$ )

Refrão

Estrofe 3 (frase $b$ - 4x - e $a$ ”)

Refrão (instrumental)

Estrofe 3 (frase $b$ - 4x - e $a$ ”)

Refrão

Coda (Frases da introdução)

\begin{tabular}{|l|l|l|l|l|}
\multicolumn{1}{c}{ M R } & $\mathrm{F}$ & \multicolumn{2}{c|}{ Cad. } \\
\hline Macaco não é valente & 7 & $a$ & Frases $a$ & \\
\hline Dança aí dezessete na corrente & 10 & $a$ & & $6-5$ \\
\hline Macaco não é valente & 7 & $a$ & Frase $a$ & \\
\hline Dança aí dezessete na corrente & 10 & $a$ & & $3-1$ \\
\hline
\end{tabular}

Tab.4.6 17 na Corrente: Refrão.

A tabela acima apresenta as relações entre música e estrutura poética no refrão. A repetição da letra apresenta finais diferenciados entre 6-5 interrogativo e 3-1 afirmativo. Já a estrofe 1 é composta por oito versos e as rimas se encadeiam entre as frases: o $2^{\circ}$ verso da frase $b$ rima com o primeiro da próxima frase, e assim sucessivamente até a frase cadencial $a$ ”. Esta última apresenta o final 3-1, que se diferencia do final $3+5$ da frase $b$, pontuando o final da seção e a entrada do refrão. 


\begin{tabular}{|l|l|l|l|l|}
\multicolumn{1}{l}{} & M & R F & \multicolumn{1}{c|}{ Cad } \\
\hline Numa viagem que fiz pelo Amazonas & 11 & $a$ & Frase $b$ & \\
\hline Num arvoredo parei pra descansar & 11 & $b$ & & $3+5$ \\
\hline Me jogaram uma pedra no lugar & 11 & $b$ & Frase $b$ & \\
\hline Eu olhei não vi nada ali perto & 10 & $c$ & & $3+5$ \\
\hline Com distância de dez ou doze metros & 10 & $c$ & Frase $b$ & \\
\hline Um guariba surgiu na minha frente & 10 & $d$ & & $3+5$ \\
\hline Com coragem enfrentei o descontente & 10 & $d$ & Frase $b$ & \\
\hline Venci a luta e a ele eduquei & 11 & $e$ & & $3+5$ \\
\hline Minha ordem pra ele é uma lei & 10 & $e$ & Frase $a ”$ & \\
\hline Dança aí dezessete na corrente... & 10 & $d$ & & $3-1$ \\
\hline
\end{tabular}

Tab.4.7 17 na Corrente: Estrofe 1.

\subsection{O Canto da Ema (João do Vale, A. Cavalcanti e Ayres Viana)}

Essa canção se tornou referencial na musica popular brasileira devido à suas regravações e citações na década de $1970 .{ }^{99}$ A primeira gravação consta do $3^{\circ}$ long playing de Jackson do Pandeiro, Jackson e Almira - Os Donos do Ritmo. ${ }^{100}$

A alusão ao tronco da Jurema a conecta ao estudado gênero do catimbó, com a superstição relacionada ao canto do referido pássaro. Outro dado importante é o das notas repetidas nas frases $b$ e $c$ que também são bastante comuns aos cocos, como demonstram os exemplos 59, 63, 66, 67, 70, entre outros, de Andrade (2002).

Composta basicamente no $5^{\circ}$ modo (mixolídio), é apenas no $2^{\circ}$ refrão que se faz explícito com o uso do fa natural. Até então, poderia se pensar tratar-se do $1^{\circ}$ modo (jônio) sem o uso da sensível, já que o traço cadencial melódico 6+1 é facilmente percebido. Novamente a harmonização é baseada nos três principais graus I, IV e V, sendo o IV da tipologia dominante sem exercer a mesma função. Do ponto de vista formal, trata-se de uma sentença circundada por dois refrões.

\footnotetext{
99 Gilberto Gil no long playing Expresso 2222 (1972), e Djavan na canção Capim, do álbum Luz (1982).

${ }^{100}$ Rio de Janeiro: Copacabana, CLP 2044.
} 


\section{O Canto da Ema}

João do Vale et al
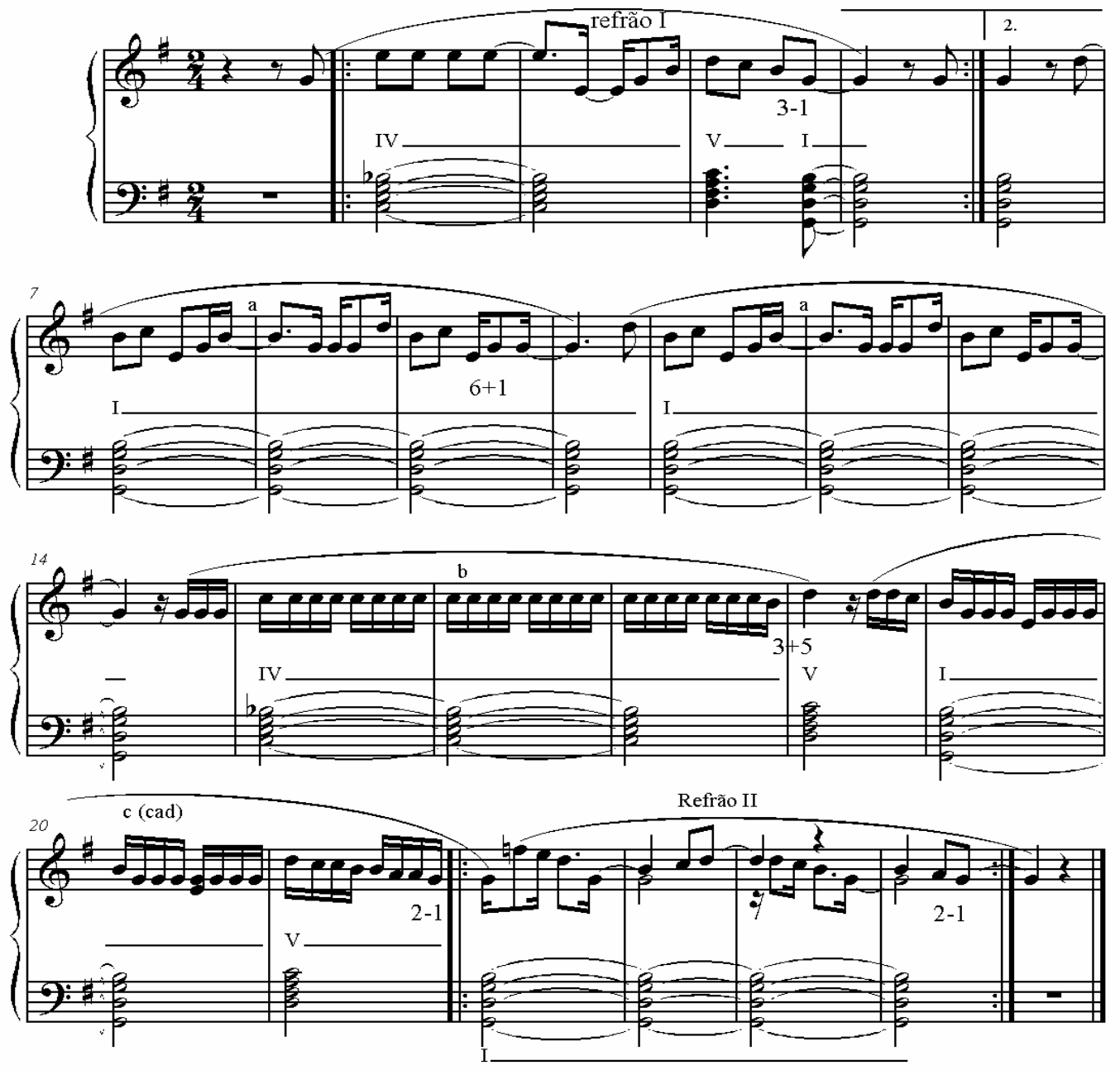

Fig.4.9 O Canto da Ema

O arranjo dessa canção se dá da seguinte maneira: 
Introd. (refrão 1 e frase $a$ ) - instrumental

Canto: refrão 1; frases $a, a^{\prime}, b$ e $c$; refrão 2

refrão 1 ; frases $a, a^{\prime}, b$ e $c$; refrão 2

Interlúdio (refrão 1 e frase $a$ e variação) - instrumental

Canto: frases $b$ e $c$, refrão 2

refrão 1 ; frases $a, a^{\prime}$; refrão 1 (fim)

Diferentemente dos baiões de Luiz Gonzaga, ligados aos repentes nordestinos nos quais a regularidade métrica está baseada, sobretudo, nos versos de sete sílabas (redondilha maior), o estilo de Jackson, baseado no coco, comporta algumas explosões verborrágicas, como as encontradas nas frases $b$ e $c$.

M R Fraseologia Cad.

\begin{tabular}{|c|c|c|c|c|}
\hline A Ema gemeu & 5 & $a$ & Semifrase 1 & \\
\hline No tronco do Jurema & 7 & $b$ & Semifrase 2 & $3-1$ \\
\hline
\end{tabular}

Tab.4.8 O Canto da Ema: Refrão I.

M R Frase Cad.

\begin{tabular}{|l|r|r|r|r|}
\hline Foi um sinal bem triste, morena & 9 & $a$ & Fr. $a$ & \\
\hline Fiquei a imaginar & 6 & $b$ & “ ” & $6+1$ \\
\hline Será que é o nosso amor, morena & 9 & $a$ & Fr. $a$ ’ & \\
\hline Que vai se acabar & 6 & $b$ & “ ” & $6+1$ \\
\hline Você bem sabe que a Ema quando canta vem trazendo no seu & 28 & $b$ & Frase & $3+5$ \\
canto um bocado de azar. & & & $b$ & \\
\hline Eu tenho medo pois acho que é muito cedo & 12 & $c$ & Fr.c & \\
\hline Muito cedo meu benzinho pra esse amor se acabar & 15 & $b$ & “» & $2-1$ \\
\hline
\end{tabular}

Tab.4.9 O Canto da Ema: estrofe. 
M R Fraseologia Cad.

\begin{tabular}{|c|c|c|c|c|}
\hline Vem, morena (vem, vem, vem) & 7 & $a$ & Semifrase 1 & \\
\hline Me beijar (me beijar) & 6 & $b$ & Semifrase 2 & 2-1 \\
\hline Dá um beijo (dá um beijo) & 7 & $c$ & Semifrase 1 & \\
\hline Pra esse medo (se acabar) & 8 & $b$ & Semifrase 2 & 2-1 \\
\hline
\end{tabular}

Tab.4.10 O Canto da Ema: refrão II.

\subsection{Considerações Parciais}

Não se pretende neste capítulo fazer levantamentos exaustivos dos procedimentos adotados pelos compositores-intérpretes mencionados, como no capítulo anterior. Tais dados serão cotejados na Conclusão. Por enquanto, o mais importante é demonstrar como alguns daqueles elementos imanentes no repertório étnico foram enfatizados na caracterização popular desses gêneros nordestinos, principalmente os do coco e do baião.

É importante ressaltar que a questão autoral não é aqui tão relevante, mas, sim, o passado musical desses autores ligado a tradições locais. Segundo Dreyfus (1996) tanto Juazeiro, quanto Asa Branca eram músicas que Luiz Gonzaga já ouvia na sua infância, e Jackson do Pandeiro só começou a assinar as autorias a partir de 1957, embora interferisse nas canções através da sua interpretação ${ }^{101}$. Essa também foi a características dos primeiros compositores cariocas de samba que traziam melodias advindas de práticas orais e coletivas e transportadas através de arranjos e harmonizações para o nível da cultura de massa. ${ }^{102}$

Das cinco canções analisadas, quatro se encontram no $5^{\circ}$ modo diatônico puro (mixolídio), apenas uma (Vem, Morena) encontra-se no $2^{\circ}$ modo (dórico) apesar de esse modo, como visto no capítulo dedicado às melodias tradicionais, não ter figurado de modo quantitativamente relevante. Todas as melodias apresentaram o traço melódico 6+1 e, mesmo se tratando de melodias modais, forma harmonizadas tonalmente, exceção feita apenas ao modal vamp encontrado em Vem, Morena.

Também curioso foi o uso nas harmonizações do IV grau com $7^{\mathrm{a}}$ menor, característica que se pode atribuir a pelo menos duas hipóteses: ao próprio modo $5^{\circ}$ modo (mixolídio) que, transposto ao IV grau, traria essa estranha extensão, e ao uso do acordeão que, como se sabe, tem para a mão esquerda fileiras de quatro botões que dão o baixo e os acordes

\footnotetext{
101 Tal é também a característica de Mulher Rendeira, que, encontrada no Ensaio sobre a Música Brasileira (1928) de Mário de Andrade, e que foi atribuída posteriormente a Zé do Norte.

${ }^{102}$ É bastante conhecida esta frase do compositor Sinhô: "samba é como passarinho, é de quem pegar".
} 
correspondentes maior, menor, diminuto e dominante. Exatamente este último traria a extensão mencionada.

Portanto, parecem ser a harmonização e os arranjos que estilizam o gênero ainda que, naquele momento, como demonstrado no decorrer das análises, sejam bastante simples e diretos, com introduções que utilizam trechos melódicos usados posteriormente em codas e interlúdios. De todas as canções analisadas, somente o Baião possui seção B claramente delimitada, devido à digressão para a região da subdominante, tratando-se as demais de simples sentenças. Não foram encontrados períodos, o que demonstra que nesses gêneros a repetição imediata da frase é bastante importante na respectiva caracterização.

É importante ressaltar que, mais uma vez, foi selecionado um material com características modais que são parte da obra dos autores estudados. Ou seja, há novamente a localização de uma parte, ainda que significativa e talvez qualitativamente mais importante, dentro de uma obra que também passa por outros gêneros de caracterização tonal.

Na obra de Paz (2002) todos compositores eruditos brasileiros ligados de alguma forma ao aproveitamento do material étnico, que fizeram uso do modalismo nas características aqui expostas, são da segunda ou terceira geração nacionalista ${ }^{103}$. Em outras palavras, não foram encontradas tais características, como mencionado em Villa-Lobos, por exemplo, em compositores como Fructuoso Vianna, Francisco Mignone, Radamés Gnattali e Camargo Guarnieri na produção anterior aos anos 1950. As peças inspiradas em batuque de negros apresentam, eventualmente, o pentatonismo como, por exemplo, em Dança Negra (1946), de Guarnieri, e Dança de Negros (1923), de Vianna, entre muitas outras, estilizando também o exotismo dos ritmos afro-brasileiros ${ }^{104}$. É somente na produção posterior à década de 1950 que tais elementos figurarão em obras como Concerto para Orquestra de Cordas e Percussão (1972), de Camargo Guarnieri, dedicada à Orquestra Armorial que, naquela década, fazia um trabalho no estado de Pernambuco de valorização da cultura popular e aproveitamento de seu material através do movimento Armorial. Mesmo as peças de GuerraPeixe, inspiradas diretamente nas manifestações étnicas, são posteriores aos anos de 1950, década em que realizou sua importante e mencionada obra Maracatus do Recife.

\footnotetext{
${ }^{103}$ Entre eles estão: Edino Krieger, Ernest Mahle, Ernest Widmer, Guerra-Peixe, José Siqueira, Marlos Nobre, Osvaldo Lacerda.

104 “A Bahia é, a meu ver, uma fonte inesgotável de motivos para o compositor que queira realmente trabalhar. Aqui para o norte, [...], é que se pode procurar os alicerces de uma escola musical brasileira. Parece-me que essas bases serão lançadas agora, com o material recolhido carinhosamente pelo meu collega, o maestro Camargo Guarnieri, que considera, como eu, proveitosíssima essa viagem à Bahia.” (VIANNA apud CASTRO, 2003, p.47)
} 
Finalizando, seria um tema de investigação futura a hipótese de que as segundas e terceiras gerações nacionalistas da música erudita brasileira, se não partiram da própria produção de Luiz Gonzaga, é pelo menos a partir dela que o interesse pelo folclore nordestino se amplia para que, posteriormente, tais compositores incluam em suas obras as características mencionadas. Já o caso de Jackson será mais importante quando se tratar a seguir da questão do tropicalismo, muito embora, sua obra partilha de um matiz bastante semelhante. 


\section{Algumas Utilizações do Modalismo no Repertório Selecionado da Música Popular do Brasil da década de 1960}

Dentro de um contexto cultural e histórico amplo, as manifestações musicais da década de 1960 no Brasil giraram em torno de posições que se radicalizaram, à medida que a ditadura militar avançava e endurecia no sentido das restrições dos princípios democráticos. Acredita-se que, em contrapartida, a partir da canção de protesto um mesmo ethos regeu a música de alguns compositores daquela década, cuja razão pretende-se apontar aqui através da análise, destacando procedimentos comuns em três diferentes compositores: Baden Powell em seus afro-sambas, Edu Lobo antes da viagem aos Estados Unidos da América no final da década e Milton Nascimento em seus primeiros álbuns. O recorte aqui escolhido procura confrontar as fontes editadas nos songbooks de Almir Chediak (Bossa Nova e Edu Lobo) e do Latin Real Book, dos quais constam as canções com as gravações históricas retiradas dos álbuns citados a seguir. Muitas vezes a canção foi transcrita diretamente da gravação, como no caso de Morro Velho e Canção do Sal, de Milton Nascimento.

\subsection{Baden Powell}

\subsubsection{Consolação}

As análises que se seguem obedecem a uma ordem histórica do surgimento dessas canções. A primeira versão de Consolação consta do álbum Baden à Vontade (Powell, 1962) que, lançado naquele ano pela gravadora Elenco, opunha-se, de uma certa forma, aos dois primeiros álbuns de Baden que tinham arranjos semi-orquestrais ${ }^{105}$. Nesse disco há predominantemente violão e percussão (bateria).

\section{Harmonia Parte A}

A harmonia da parte A se resume em uma repetição dos graus I e V de Ré menor. Sendo o V grau não dominante, pois se trata de um acorde menor com $7^{\mathrm{a}}$ menor, acredita-se que se trata de uma priorização modal baseada no gênero pentatônico, pois na soma das notas dos dois acordes encontra-se a escala com uma nota adicional: Dm7 (re-fa-la-do) + Am7 (la-

${ }^{105}$ Baden e Um Violão na Madrugada, ambos pela gravadora Philips, de 1959 e 1960, respectivamente. 
do-mi-sol) = re mi fa sol la do, que harmoniza a melodia no $5^{\circ}$ modo do gênero pentatônico . Observe-se o exemplo abaixo, que também apresenta o final cadencial:

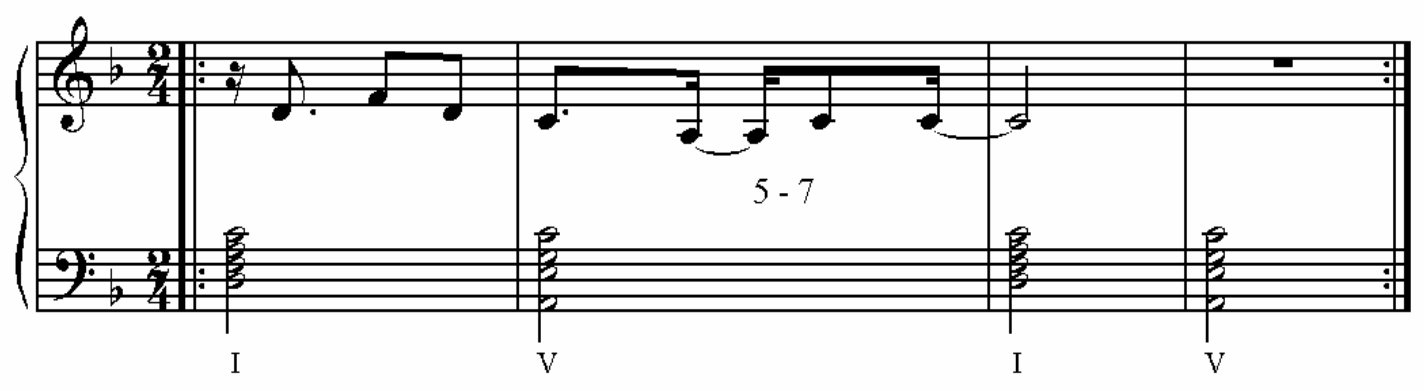

Ex.5.1 Consolação: trecho de A.

Harmonia Refrão (tonal com cadências modais)

O refrão ou parte $\mathrm{B}$ da canção apresenta características tonais devido à relação V(dominante) - I apresentada no $3^{\circ}$ compasso do exemplo abaixo. No entanto, há uma insistência no V (não dominante) que pontua os dois finais do antecedente (frase $b$ ) e conseqüente (frase $c$ ), evitando, assim, uma “tonalização” total. Do ponto de vista melódico, observa-se uma ampliação do $2^{\circ}$ modo do gênero pentatônico com a inclusão da $2^{\mathrm{a}}$ maior (a nota mi). A semifrase cadencial extra realiza o movimento 3-1-7+1, muitas vezes harmonizado com o acorde Eb7M (IIb), que traz a sensação do $3^{\circ}$ modo (frígio) no movimento cadencial IIb - I, harmonizando a mesma pentatônica. 

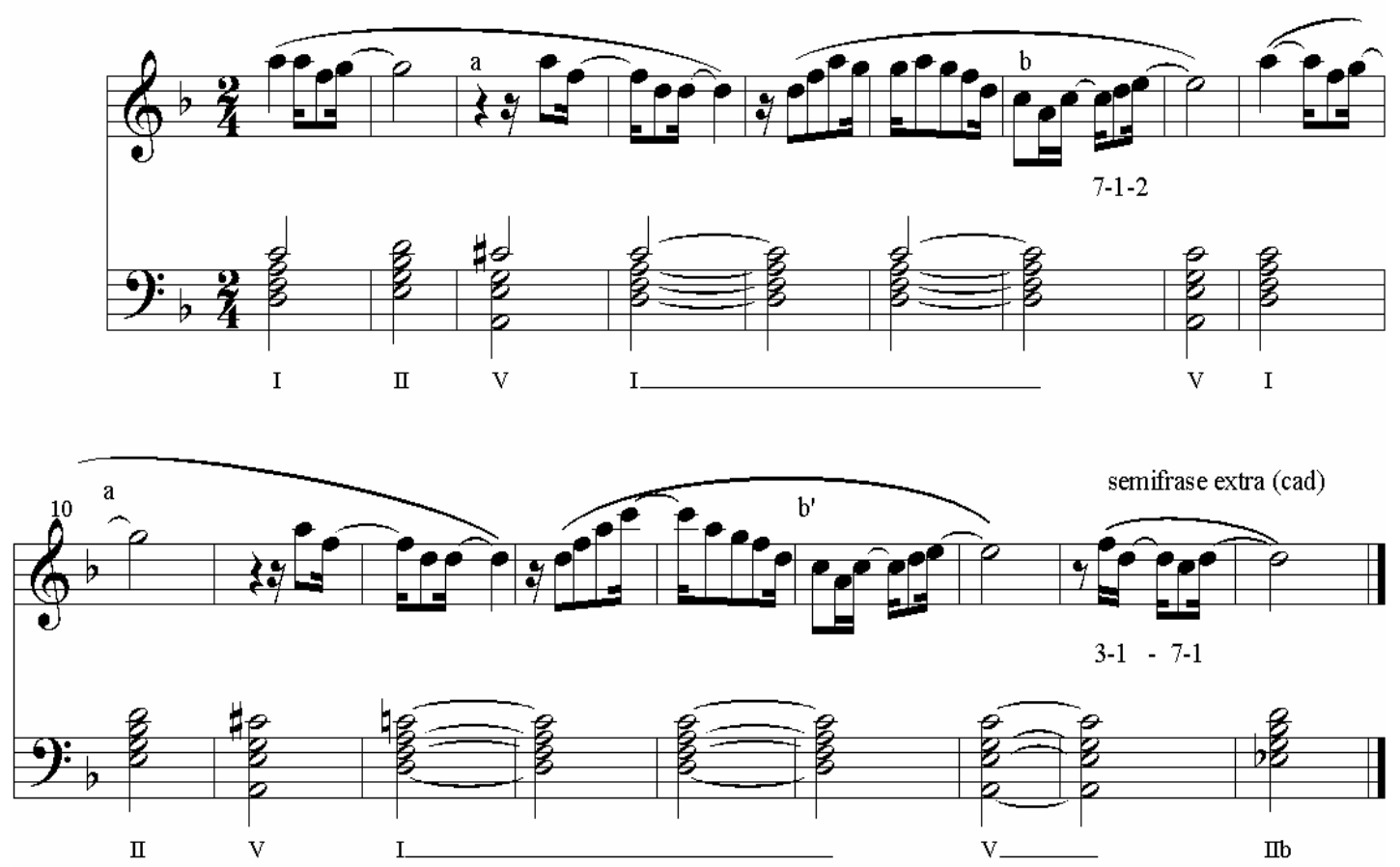

Ex. 5.2 Consolação: refrão.

Forma do Arranjo

Em relação à forma do arranjo, constata-se que na gravação escolhida há uma apresentação do tema e uma série de improvisações rítmicas com diálogos entre bateria e violão de grande virtuosidade ${ }^{106}$. Os instrumentistas chegam a sugerir um ritmo composto baseado na hemíola ou ritmo ternário de unidade de semínima pontuada. Após essa seção de improvisação, há a re-exposição da parte B.

A estrutura apresentada para esta canção na gravação escolhida é bastante simples:

\section{A B (Refrão) Improvisações Rítmicas B (Refrão)}

Parte A: estrutura ternária (24 compassos)

A tabela a seguir expõe uma comparação entre a estrutura poética em termos de métrica e rima e fraseologia musical, além da terminação fraseológica ${ }^{107}$. Sendo constituída de seis frases após a introdução, classifica-se em estrutura ternária a Parte A, fato corroborado pela totalidade do número de compassos (24). Há uma relação interessante entre a sextilha

\footnotetext{
${ }^{106}$ Entretanto, essas improvisações não ocorrem dentro de um padrão harmônico-estrutural, como no caso jazzístico.

${ }^{107}$ Corroborada pelos exemplos musicais.
} 
forçada pela repetição adicional do último verso (Melhor era tudo se acabar) e a estrutura ternária. Além disso, apenas a segunda frase musical $b$ não corresponde à rima $b$, mas, neste caso, o verso corresponde à frase musical. Observa-se também um número crescente de sílabas poéticas após cada repetição de frase:

Métrica Rima Frase Musical

Cad.

\begin{tabular}{|lcr|lr|}
\hline Melhor era tudo se acabar (2x) & & Introdução & $5+7$ \\
\hline Se não tivesse o amor & $(7)$ & $a$ & Frase $a$ & \\
\hline Se não tivesse essa dor & $(7)$ & $a$ & Frase $a$ (repetição) & $5+7$ \\
\hline E se não tivesse o sofrer & $(8)$ & $b$ & Frase $b\left(a^{`}\right)^{\prime}$ & $3-1$ \\
\hline E se não tivesse o chorar & $(8)$ & $c$ & Frase $b$ (ou repetição de $a{ }^{`}$ ) & \\
\hline Melhor era tudo se acabar & $(9)$ & $c$ & Frase $c$ & \\
\hline Melhor era tudo se acabar & $(9)$ & $c$ & Frase $c$ (repetição) & \\
\hline
\end{tabular}

Tab.5.1 Consolação: seção A

\section{Refrão (período irregular)}

Esta seção apresenta uma irregularidade métrica; cada verso é constituído de um número diferente de sílabas que são correspondidas por uma irregularidade fraseológica, na medida em que, após a frase $c$ - que corresponderia, normalmente, à cadência do período - há uma extensão de dois compassos que formam um semifrase cadencial extra para concluir com o verso: mais do que eu. Observa-se também outra irregularidade na correspondência dos versos com as frases musicais.

Refrão

\begin{tabular}{|lrl|lr|}
\hline Eu amei, amei demais & (7) & $a$ & Frase $a$ & $3-1$ \\
\hline O que eu sofri por causa do amor (9) & $b$ & \multicolumn{2}{l|}{ Frase $b$ (dois versos formam uma frase) } \\
\hline Ninguém sofreu & $(4)$ & $c$ & “ & “ \\
\hline
\end{tabular}

\begin{tabular}{|lll|lr|}
\hline Eu chorei, perdi a paz & (7) $a$ & Frase $a$ & $3-1$ \\
\hline Mas o que eu sei & $(4)$ & $d$ & Frase $c$ (dois versos formam uma frase) \\
\hline É que nunca ninguém teve mais & $(9)$ & $b$ & “ & “ \\
\hline Mais do que eu & $(4)$ & $c$ & (semifrase cadencial extra) & $1-7+1$ \\
\hline
\end{tabular}




\subsubsection{Berimbau (Baden Powell e Vinícius de Moraes)}

Este clássico da música popular brasileira consta do mesmo álbum anterior (Powell, 1962) e possui características bastante semelhantes com a peça anterior: a parte A é constituída pelo que os músicos de jazz chamam de vamp modal, ou seja, uma repetição prolongada de dois acordes, sendo um deles priorizado sem o artifício do acorde dominante com função respectiva ${ }^{108}$.

\section{Harmonia Parte A}

Como referido anteriormente, trata-se de uma seqüência em ré menor, cuja tônica é priorizada através do V grau não dominante (menor). A melodia neste trecho é composta apenas pelas notas do, ré, mi e fá, respectivamente $7^{\mathrm{a}}$, tônica (1), $2^{\mathrm{a}}$ e $3^{\mathrm{a}}$ de ré menor.

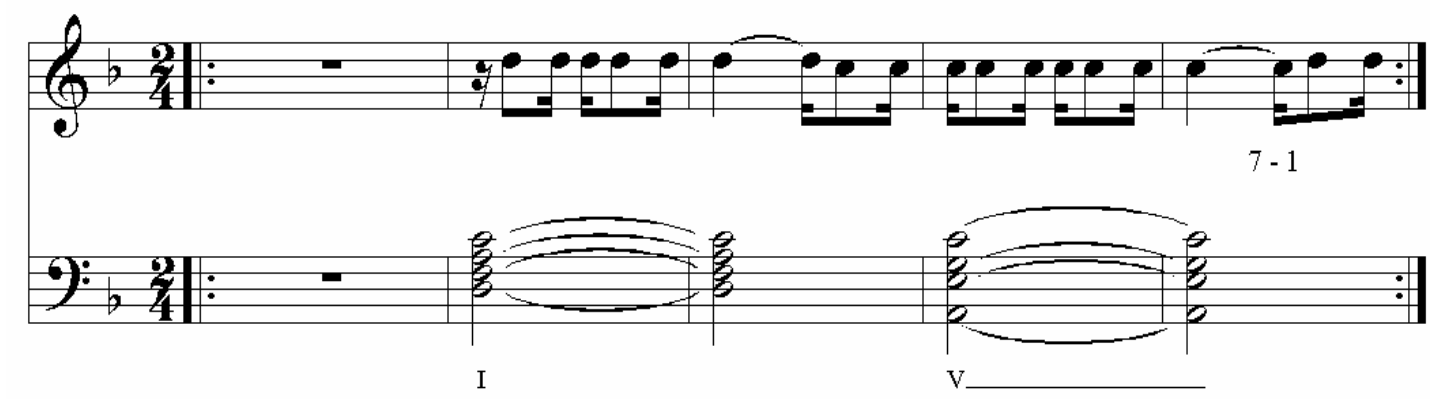

Ex. 5.3 Berimbau: trecho de A.

Toque do Berimbau (dórico)

A frase $c$ da parte A compõe a cadência da seção e realiza uma seqüência no $2^{\circ}$ modo do gênero diatônico puro (dórico) com a repetição do I grau menor com $7^{\mathrm{a}}$ e do IV grau maior. Este toque parece corresponder a uma estilização do toque de São Bento Pequeno e uma de suas variações correspondentes. (GALM, 1997, p.48-63)

\footnotetext{
${ }^{108}$ Alguns músicos de jazz acham possível a ocorrência do acorde dominante sem função de dominante, como o caso do I e IV graus dos acordes do Blues. Ver GUEST, 1994.
} 


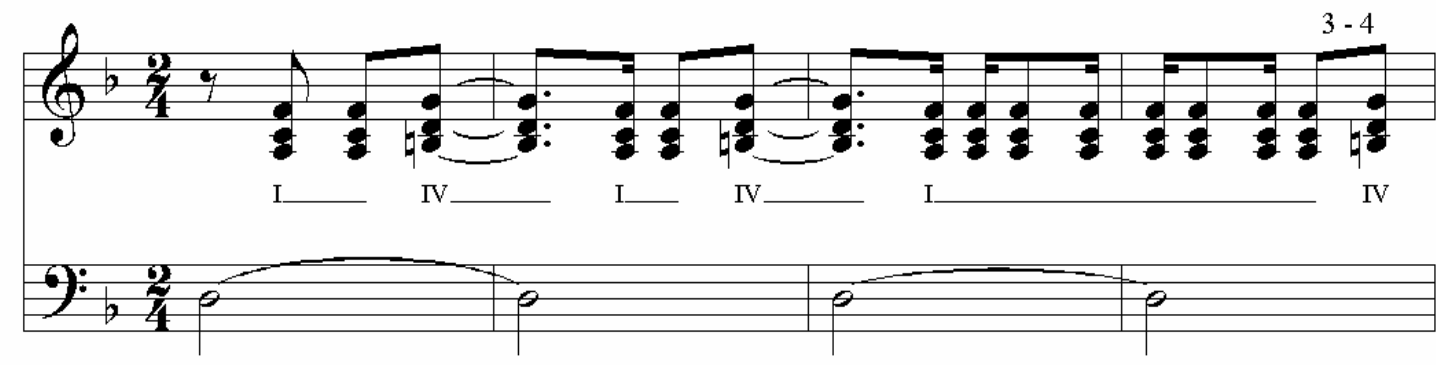

Ex. 5.4 Berimbau: toque.

Pode-se dizer que toda a seção A encontra-se no $2^{\circ}$ modo (dórico), na medida em que a nota si bemol não figura e a nota si natural pertence ao toque.

\section{Refrão}

O refrão ou parte B apresenta uma harmonia tonal, como em Consolação, devido às cadências harmônicas II - V do III, V do IV e Vger. do V. A melodia se baseia no $6^{\circ}$ modo do gênero diatônico puro de fá maior (eólio). As duas finalizações - da $1^{\mathrm{a}}$ vez e da repetição são iguais, mas, do ponto de vista harmônico, a $1^{\mathrm{a}}$ vez conclui de maneira suspensiva no acorde napolitano (IIb), como na harmonização alternativa de Consolação, e a repetição conclui afirmativamente no I grau.
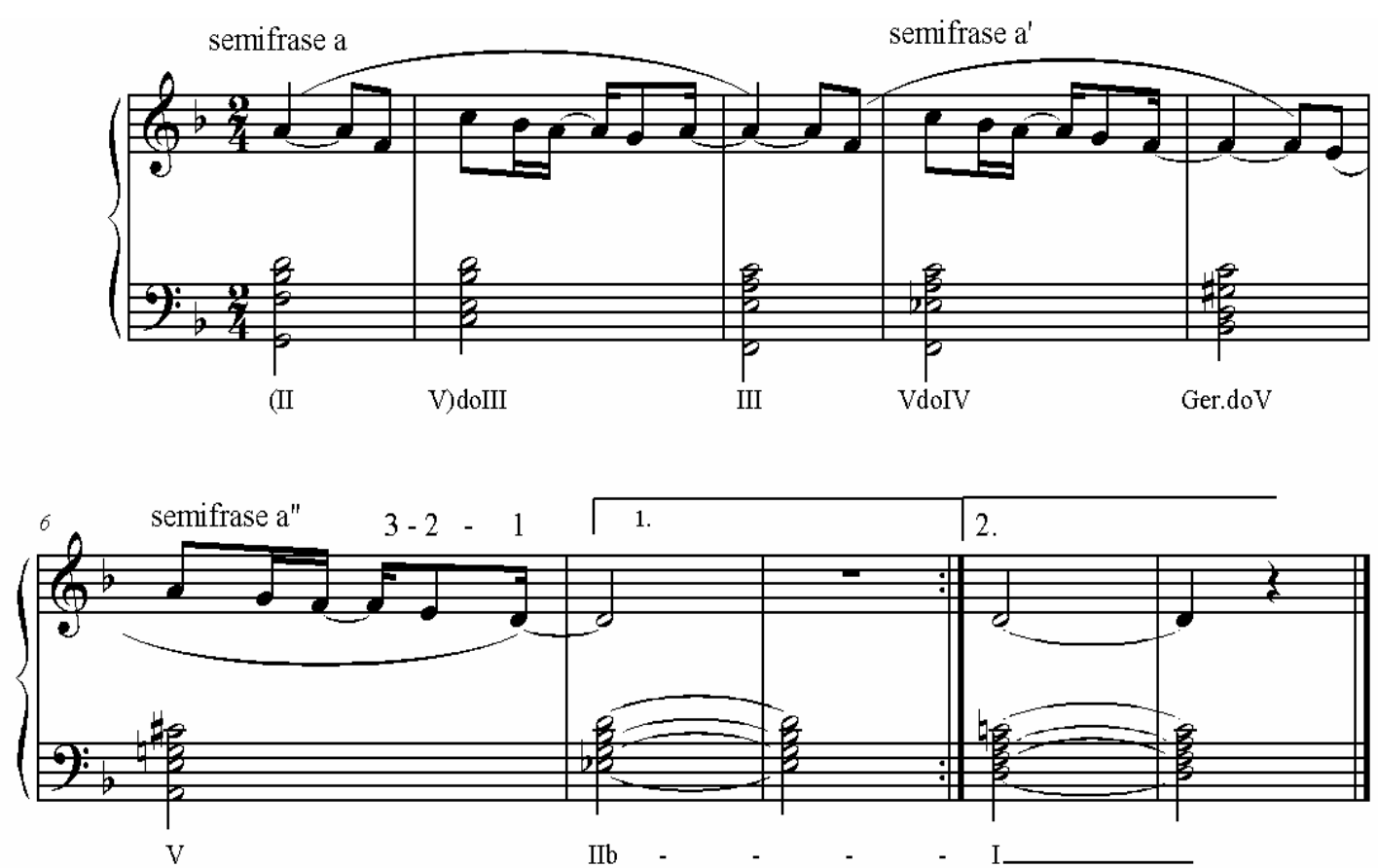

Ex. 5.5 Berimbau: refrão. 
Dentre as melodias estudadas neste capítulo, pode-se dizer que esta é a primeira de caráter modal (sem sensível) com harmonização tonal.

\section{Forma da Gravação}

Com muitas variações e improvisos, o arranjo de Berimbau assim se dá:

Introd. (toque) - A - toque - B (Refrão cantado) - toque (improvisações sobre) - A (com hemíola) - A' (variações rítmicas) - toque (improvisações) - Dm7 (acorde final). ${ }^{109}$

\section{Parte A - Estrutura ternária (24 compassos)}

Do ponto de vista fraseológico também se trata de uma estrutura ternária. Mas, aqui dois versos correspondem a uma frase musical e não há correspondência direta entre repetição de frase e rima poética - cada viés artístico segue um caminho próprio. A correspondência se daria entre um grupo de 12 versos e os 24 compassos. Mas, no lugar dos dois últimos versos, há a frase $c$ que executa o “toque” do berimbau. A métrica poética é sempre de oito sílabas.

$\mathrm{a}$

\begin{tabular}{|ll|ll|}
\hline Quem é homem de bem, não trai & (8) $a$ & \multicolumn{2}{|l|}{ Frase $a$ (dois versos formam uma frase) } \\
\hline O amor que lhe quer o seu bem & (8) $b$ & “ “ & $7+1$ \\
\hline Quem diz muito que vai, não vai & (8) $a$ & Frase $a$ (repetição) \\
\hline E assim com vai, não vem & (8) $b$ & “ “ “ & $7+1$ \\
\hline
\end{tabular}

$\mathrm{a}^{\prime}$

\begin{tabular}{|ll|ll|}
\hline Quem de dentro de si, não sai & (8) $a$ & Frase $b$ \\
\hline Vai morrer sem amar ninguém & (8) $b$ & “ “ & $2-1$ \\
\hline O dinheiro de quem não dá & (8) $a$ & Frase $b$ (repetição) & \\
\hline$\underline{\text { É o trabalho de quem não tem }}$ & (8) $b$ & “ ““ & $2-1$ \\
\hline
\end{tabular}

b (a”)

\begin{tabular}{|ll|lr|}
\hline Capoeira que é bom, não cai & (8) $a$ & Frase $a$ & \\
\hline E se um dia ele cai, cai bem & (8) $b$ & “ & \\
\hline Toque do Berimbau & & Frase $c$ (cadência) & $3+4$ \\
\hline
\end{tabular}

Tab.5.3 Berimbau: seção A.

\footnotetext{
${ }^{109}$ Aqui não é nítida a diferença entre improvisações e variações, pois não se sabe até que ponto essas “evoluções” foram feitas no momento da gravação ou preparadas.
} 


\section{Refrão}

O refrão apresenta uma estruturação peculiar: do ponto de vista fraseológico é constituído por três semifrases que, entretanto, não compõem uma estrutura ternária por ser composta de oito compassos. Poder-se-ia considerar a $1^{\text {a }}$ vez como um antecedente e a repetição como um conseqüente, mas ainda assim a divisão interna das semifrases não seria regular. Do ponto de vista poético, trata-se de dois tercetos.

\begin{tabular}{|lll|lr|}
\hline Capoeira me chamou & $(7)$ & $a$ & Semifrase $a$ \\
\hline Dizer que já chegou & $(6)$ & $a$ & Semifrase $a$ \\
\hline Chegou para lutar & $(6)$ & $b$ & Semifrase $a ”$ & $3-2-1$ \\
\hline
\end{tabular}

\begin{tabular}{|lll|lr|}
\hline Berimbau me confirmou & $(7)$ & $a$ & Semifrase $a$ \\
\hline Vai ter briga de amor & $(6)$ & $a$ & Semifrase $a$ \\
\hline Tristeza camará & $(6)$ & $b$ & Semifrase $a ”$ & $3-2-1$ \\
\hline
\end{tabular}

Tab.5.4 Berimbau: refrão.

\subsubsection{Canto de Ossanha (Baden Powell e Vinícius de Moraes)}

Lançada no álbum Afro-sambas (Powell, 1966), tornou-se um clássico da chamada música popular brasileira principalmente a partir da gravação da cantora Elis Regina, de 1969, lançada pela gravadora Philips no álbum Elis: Como \& Porque.

\section{Harmonia Parte A}

Do ponto de vista harmônico, Canto de Ossanha difere um pouco dos casos anteriores por não se basear mais em uma seqüência de dois acordes. Ocorre aqui uma cadência de quatro acordes de caráter cromático descendente: I - III - II - IIb. As relações tonais estão implícitas na passagem do II para o IIb já que este (E7), na forma de dominante secundária (V do V) pode ser lido (e ouvido) como um acorde de $6^{a}$ germânica substituto de dominante individual, ou seja, Vger.do IIb. Ainda assim, a ausência do sensível do\# melódica e harmonicamente revelam intenções afro-brasileiras na canção. O pentagrama em clave de sol apresenta a melodia na três primeiras aparições sobrepostas. A soma das notas da melodia dá 
na seguinte escala: re-fa-sol-sol\#-la, que pode ser interpretada como o $5^{\circ}$ modo do gênero pentatônico sem a $7^{\mathrm{a}}(\mathrm{do})$ e com a chamada blue note (sol\#) do jazz. ${ }^{110}$

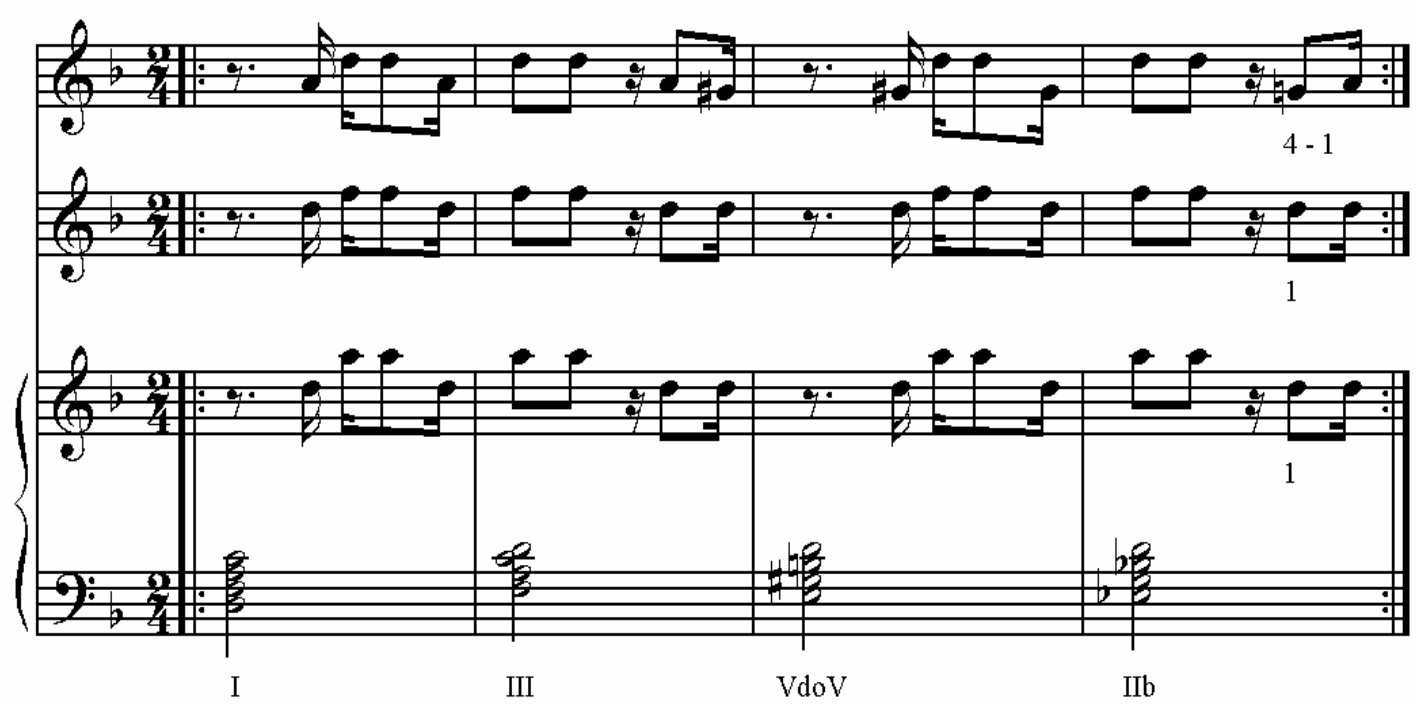

Ex. 5.6 Canto de Ossanha: melodias sobrepostas de A.

Parte B: Refrão

Tal como nas canções anteriores, a tendência rítmico-modal da seção A dá lugar ao tonalismo na seção B. O caso presente se dá na tonalidade homônima maior, relação antológica desde os choros em tonalidade menor ${ }^{111}$. Há que se lembrar também da mudança de caráter na letra, do aspecto negativo das "mandingas de amor" para o lado de se ver a “manhã de um novo amor”. Mesmo assim, o modo maior utilizado para a construção da melodia não apresenta sensível, restando alguma dubiedade melódica, ainda que as relações harmônicas sejam fortemente tonais.

\footnotetext{
110 "A microtonally lowered third, seventh, or [...] fifth degree of the diatonic scale, common in blues, jazz and related musics.” The New Grove Dictionary of Jazz, 1996, p.120.

${ }^{111}$ Ver Tiné (2001). Análises das obras Naquele Tempo (Pixinguinha), Jorge do Fusa (Garoto), Lamentos do Morro (Idem), Chega de Saudade (Tom Jobim e Vinicius de Moraes).
} 

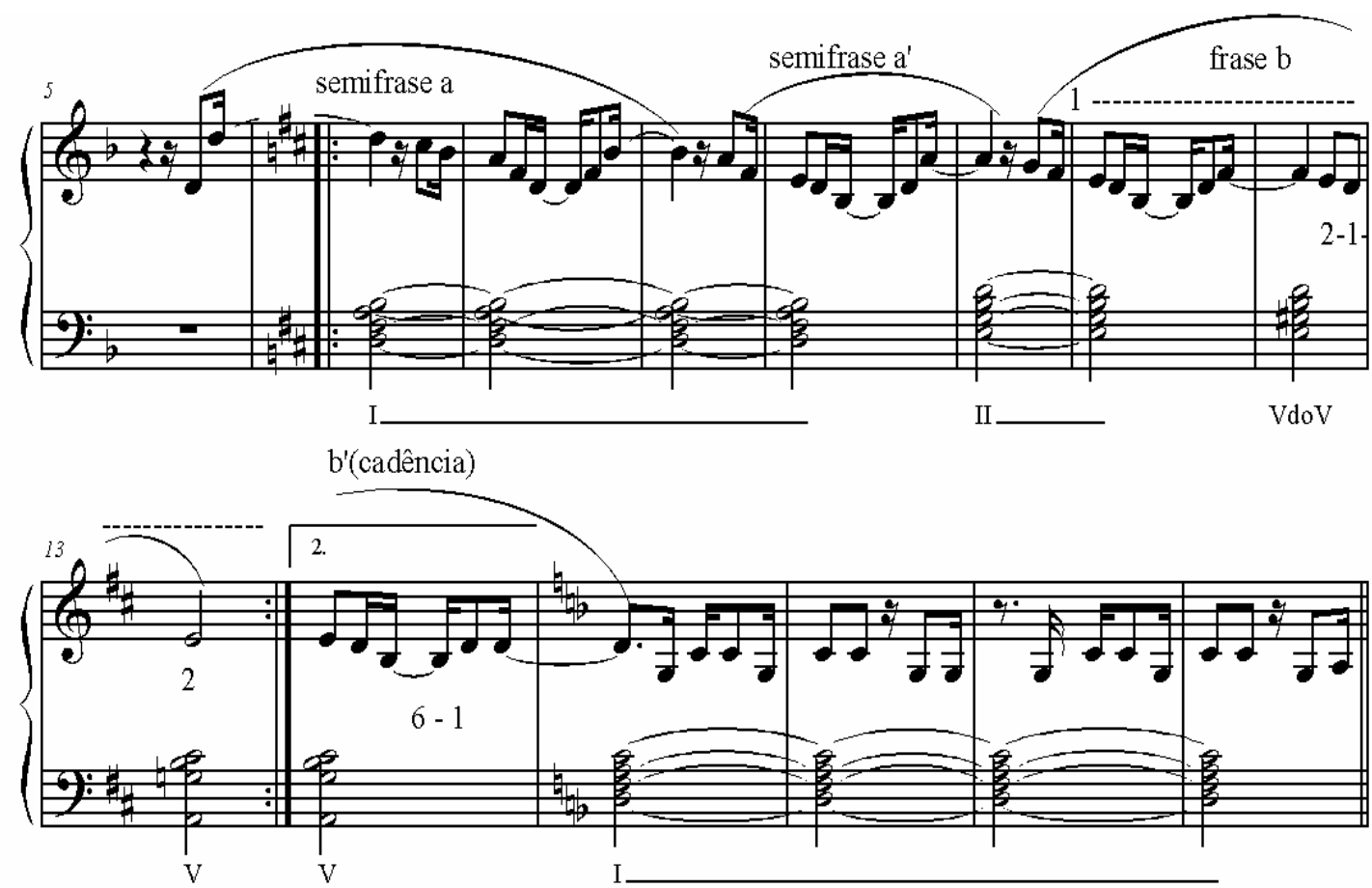

Ex.5.7 Canto de Ossanha: refrão.

Seção A: Primeira Sentença

A seção A de Canto de Ossanha é constituída por uma regularidade métrica e fraseológica que confere um caráter repetitivo. Mesmo as semifrases $c$ e $d$ são, do ponto de vista rítmico, derivadas de $a$ e $b$. Resumindo, a parte A se aproxima de uma dupla sentença ${ }^{112}$, sendo a primeira sentença formado por quatro frases (aabb) e a seção A' pela mesma estruturação com semifrases e frases diferentes, ainda que derivadas da idéia original. Nesse caso, cada grupo de oito versos corresponde a uma sentença musical.

\footnotetext{
${ }^{112}$ Não se trata de sentença no sentido estrito pela ausência da frase cadencial, possivelmente devido ao caráter mais modal do que tonal da parte A da canção.
} 


\begin{tabular}{|c|c|c|c|c|}
\hline Letra & Métrica & Rima & \multicolumn{2}{|c|}{ Frases e Cad. } \\
\hline O homem que diz “dou”, não dá & 8 & $a$ & \multirow{2}{*}{$\begin{array}{l}\text { semifrase } a \\
\text { semifrase } b\end{array}$} & \multirow{2}{*}{$\begin{array}{c}\text { Frase } a \\
4+5\end{array}$} \\
\hline Porque quem dá mesmo não diz & 8 & $b$ & & \\
\hline O homem que diz “vou”, não vai & 8 & $C$ & \multirow{2}{*}{$\begin{array}{l}\text { semifrase } a \\
\text { semifrase } b\end{array}$} & \multirow{2}{*}{$\begin{array}{c}\text { Frase } a \\
4+5\end{array}$} \\
\hline Porque quando foi já não quis & 8 & $b$ & & \\
\hline O homem que diz “sou”, não é & 8 & $a$ & \multirow{2}{*}{$\begin{array}{l}\text { semifrase } c \\
\text { semifrase } c\end{array}$} & \multirow{2}{*}{$\begin{array}{c}\text { Frase } b \\
1\end{array}$} \\
\hline Porque quem é mesmo é não sou & 8 & $b$ & & \\
\hline O homem que diz estou, não está & 8 & $C$ & \multirow{2}{*}{$\begin{array}{l}\text { semifrase } c \\
\text { semifrase } c\end{array}$} & \multirow{2}{*}{$\begin{array}{c}\text { Frase } b \\
1\end{array}$} \\
\hline Porque ninguém está quando quer & 8 & $d$ & & \\
\hline
\end{tabular}

Tab. 5.5 Canto de Ossanha: A.

Seção A: Segunda Sentença

\begin{tabular}{|c|c|c|c|c|}
\hline Coitado do homem que cai & 8 & $a$ & \multirow{2}{*}{$\begin{array}{l}\text { semifrase } a \\
\text { semifrase } b\end{array}$} & \multirow{2}{*}{$\begin{array}{c}\text { Frase } a \\
1\end{array}$} \\
\hline $\begin{array}{c}\text { Num canto de Ossanha } \\
\text { traidor }\end{array}$ & 8 & $b$ & & \\
\hline Coitado do homem que vai & 8 & $a$ & \multirow{2}{*}{$\begin{array}{l}\text { semifrase } a \\
\text { semifrase } b\end{array}$} & \multirow{2}{*}{$\begin{array}{c}\text { Frase } a \\
\qquad 1\end{array}$} \\
\hline Atrás de mandinga de amor & 8 & $b$ & & \\
\hline Vai, vai, vai, vai, não vou & 6 & $a$ & semifrase $c$ & \multirow{2}{*}{$\begin{array}{c}\text { Frase } b \\
4+5\end{array}$} \\
\hline Vai, vai, vai, vai, não vou & 6 & $a$ & semifrase $d$ & \\
\hline Vai, vai, vai, vai, não vou & 6 & $a$ & semifrase $c$ & \multirow{2}{*}{$\begin{array}{l}\text { Frase } b^{\prime} \\
1+8\end{array}$} \\
\hline Vai, vai, vai, vai (anacruse) & 6 & $\mathrm{a}$ & semifrase $d$ & \\
\hline
\end{tabular}

Tab.5.6 Canto de Ossanha: A’.

Parte B: Refrão

As palavras não vou constituem uma elisão entre o fim da seção A e o início do refrão (B). Por um lado, complementam a métrica de seis sílabas poéticas da primeira parte e, por outro, iniciam o refrão. A irregularidade métrica do ponto de vista poético é compensada pela regularidade fraseológica musical, duas estrofes de 5 e 4 versos com diferentes métricas em quatro frases que perfazem dezesseis compassos, contando a repetição. 


\begin{tabular}{|c|c|c|c|c|}
\hline Letra & Métrica & Rima & \multicolumn{2}{|c|}{ Frases e Cad. } \\
\hline Não vou, & 2 & $a$ & & \multirow{2}{*}{ Frase $a$} \\
Que eu não sou ninguém & 7 & $b$ & semifrase $a$ & \\
\hline Em ir & & & & \\
\hline A tristeza de um amor & 7 & $d$ & Frase $b$ & \\
\hline Que passou & 3 & $e$ & & $2-1+2$ \\
\hline
\end{tabular}

\begin{tabular}{|c|c|c|c|c|}
\hline Não, & 1 & $f$ & & Frase $a^{\prime}$ \\
\hline Eu só vou se for pra ver & 7 & $c$ & semifrase $a$ & \\
\hline Uma estrela aparecer & 7 & $c$ & semifrase $a^{\prime}$ & \\
\hline $\begin{array}{c}\text { Na manhã de um novo } \\
\text { amor }\end{array}$ & 7 & $d$ & Frase $b^{\prime}$ (cadência) $6+1$ \\
\hline
\end{tabular}

Tab.5.7 Canto de Ossanha: refrão.

\section{Forma da Gravação}

O arranjo original dessa canção, tal como em todo o disco Afro-sambas, é assinado pelo maestro Guerra-Peixe, profundo conhecedor da cultura popular brasileira e ligado à segunda geração nacionalista da história da música brasileira. Há uma oscilação do centro tonal entre as tonalidades de ré menor, que rege a seção $\mathrm{A}$, ré maior, correspondente à seção B e fá maior que rege a variação da seção B (B’) para o retorno às tonalidades originais:

$$
\begin{aligned}
& \text { Introd.: A A' B A } \text { B' }^{\prime} \text { A } \text { B' }^{\prime} \text { A coda } \\
& \text { Tom: Dm..... D....Dm...D F.... Dm...D...Dm....D }
\end{aligned}
$$




\subsection{Edu Lobo}

\subsubsection{Arrastão (Edu Lobo e Vinicius de Moraes)}

Arrastão é a primeira canção de Edu Lobo a se tornar um clássico. Tematicamente inspirada na Suíte dos Pescadores, de Dorival Caymmi, consta do primeiro long playing de Edu Lobo, intitulado Edu Lobo por Edu Lobo, lançado em 1965 também pela gravadora Elenco $^{113}$. Entretanto, a versão que alcançou popularidade foi a vencedora do $1^{\circ}$ Festival Excelsior de MPB, interpretada pela cantora Elis Regina no mesmo ano. Talvez por isso seja considerada por muitos a linha divisória entre a bossa nova e a música popular brasileira.

\section{Harmonia Parte A}

Do ponto de vista melódico, a seção A parte do $2^{\circ}$ modo (dórico) com o arpejo menor com $7^{\mathrm{a}}$ menor que se resolve na $6^{\mathrm{a}}$ maior do modo. Tal elemento é harmonizado com a seqüência I - II no respectivo modo que prioriza o primeiro acorde através do II grau menor com $7^{a}$ menor no baixo (baixo pedal). A terceira frase dá seqüência à melodia transposta no plano harmônico para o II grau. A quarta frase volta à cadência original, mesmo a melodia tendo sido mais uma vez transposta e adaptada. O final da frase cadencial $a$,”, como demonstrado no exemplo V.8, realiza o movimento melódico $2-7+1$, ou seja, uma bordadura diatônica em torno da tônica do modo (1), harmonizado pelo IV grau maior. Apesar do repouso melódico na tônica, há a suspensão dada pelo acorde do IV grau, que é a dominante da próxima seção.

\footnotetext{
113 “'Arrastão' nascera numa festa na casa dos Caymmi, quando se cantava a terceira parte da 'História dos Pescadores', o trecho denominado 'Temporal'. Ao improvisar um contracanto para o nome de cada um dos pescadores [...], Edu percebeu que estava nascendo uma música sob a inspiração de Dorival Caymmi. Guardou a idéia e completou a música depois, mostrando a Vinícius de Moraes quando este voltou de uma viagem.” (MELLO, 2003, p.67)
} 

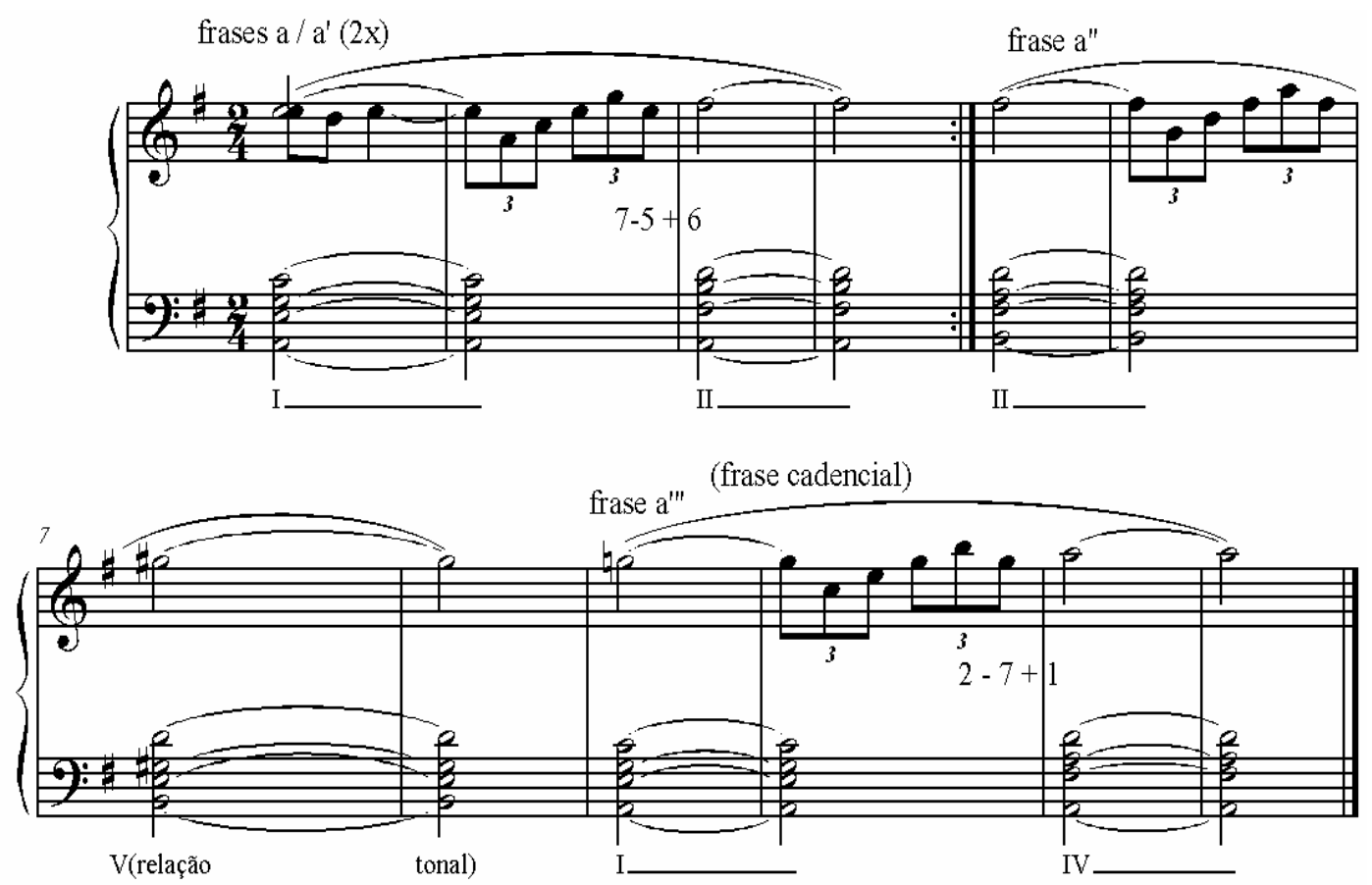

Ex.5.8 Arrastão: parte A.

Parte B (Refrão)

O que se ouve quando se atinge a região de sol maior - que poderia ser a tonalidade da canção - é que esta se mantém de maneira dúbia. Ainda que a melodia sustente um fa natural, sugerindo o $5^{\circ}$ modo da escala diatônica pura (neste caso um hipomixolídio) ${ }^{114}$ para esta seção, a harmonia oscila entre o uso do fa natural no primeiro acorde (sus79 no jargão popular) e o fa sustenido no segundo (G7M) formando, assim, o que aqui se chama de seqüência mista (ou híbrida), por pertencer a duas modalidades.

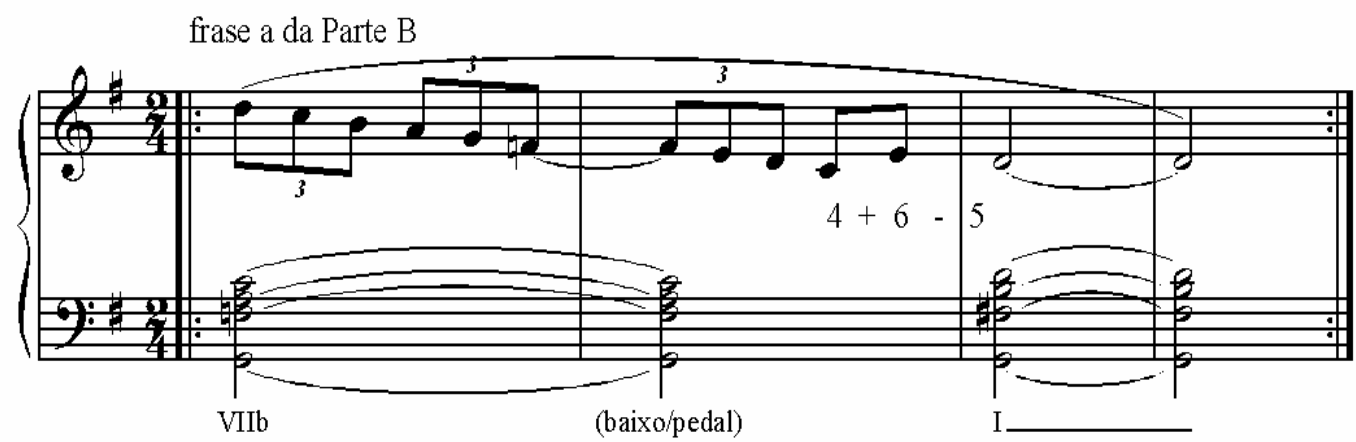

Ex. 5.9 Arrastão: refrão

\footnotetext{
${ }^{114}$ Embora se trate do dórico do ponto de vista puramente melódico, sua relação com a harmonia localiza o final da frase na $5^{\mathrm{a}}$ abaixo, caracterizando o modo plagal.
} 
A terceira parte de canção apresenta mais elementos tonais na forma de movimentos de Dominante - Tônica individuais e secundárias, bem como o uso dos acordes de $6^{\text {a }}$ aumentada (francesa no caso: Fr.) correspondentes ao subV do jazz, que também realiza priorizações tonais.
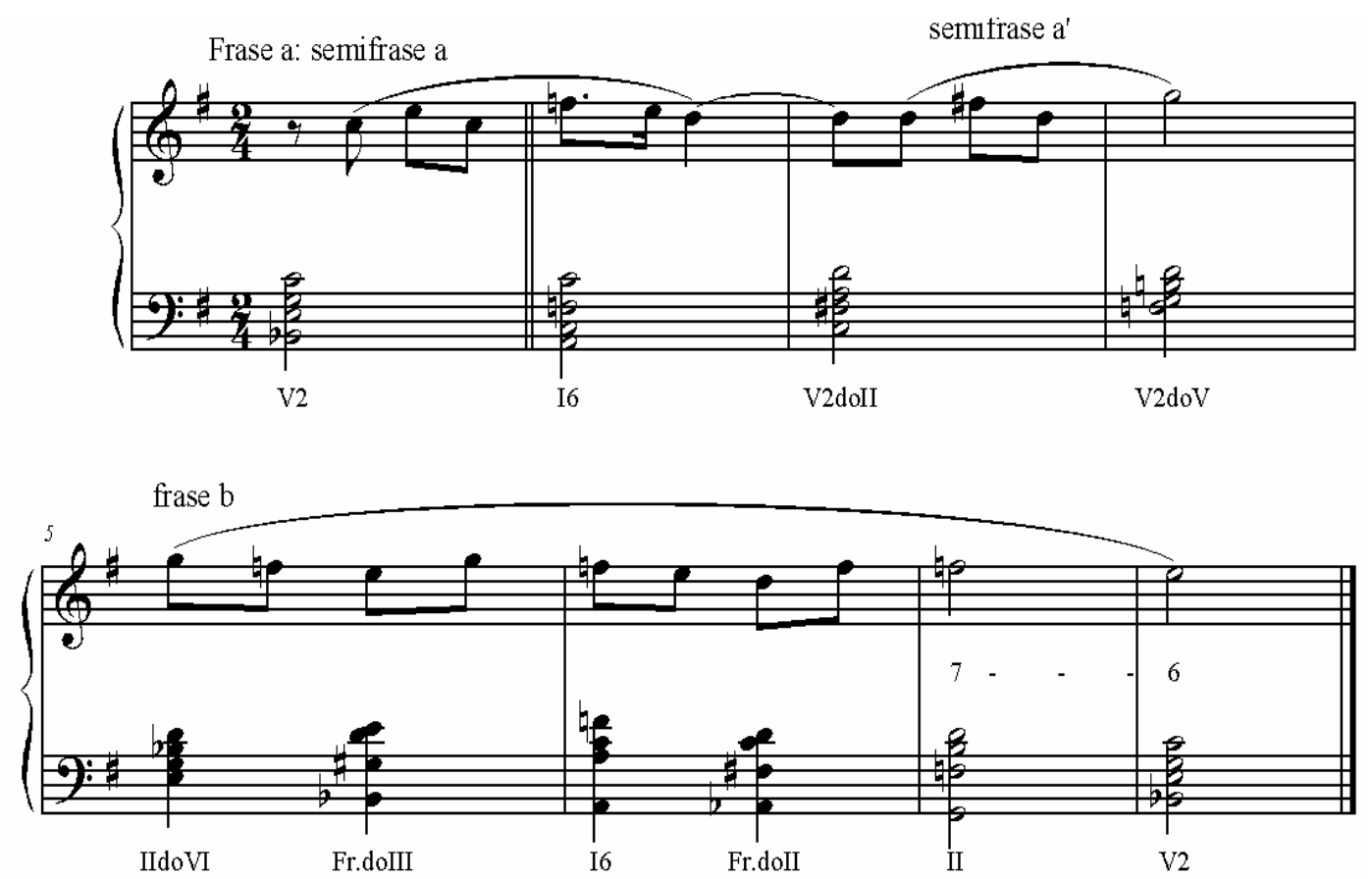

Ex. 5.10 Arrastão: parte C. ${ }^{115}$

\section{Parte A (Sentença)}

Esta seção se assemelha mais à estrutura da sentença devido à repetição seguida da frase $a$ em $a$ ' e sua transposição um tom acima em $a$ ” para, então, ser transposta e adaptada $1 / 2$ tom acima na última frase em movimento cadencial. Se por um lado as rimas não correspondem às repetições de frases, a métrica (redondilha maior) é absolutamente a mesma em todas as frases que correspondem ao verso poético, e a quadra é formada pela estrutura binária correspondente.

\footnotetext{
115 Outra possibilidade de interpretação do acorde do $5^{\circ}$ compasso Bb7(11+) é de um dó sem fundamental com $7^{\text {a }}$ no baixo, $9^{a}$ e $5^{a}$ aumentada (D), que se resolve no acorde de tônica na primeira inversão (F/A)
} 
Letra

Métrica Rima Frases

final

\begin{tabular}{|llr|lc|}
\hline$\hat{E}$, tem jangada no mar & $(7)$ & $a$ & Frase $a$ & $7-5+6$ \\
\hline$\hat{E}$ (ie, iêi) hoje tem arrastão & $(7)$ & $b$ & Frase $a$ ' \\
\hline$\hat{E}$, todo mundo pescar & $(7)$ & $a$ & Frase $a$ ” \\
\hline Chega de sombra João & $(7)$ & $b$ & Frase $a$ ”' (frase cadencial) & $2-7+1$ \\
\hline
\end{tabular}

Tab.5.8 Arrastão: seção A.

\section{Parte B (Refrão)}

A segunda parte da canção trata de repetir literalmente quatro vezes a mesma frase musical, com dois textos diferentes que rimam entre si e possuem a mesma métrica. Tudo isso antecedido por um salto de $5^{\mathrm{a}}$ ascendente que prepara o refrão.

\begin{tabular}{|l|l|}
\hline J'ouviu & Motivo: salto de $5^{\mathrm{a}}$ justa ascendente \\
\hline $\begin{array}{l}\text { Olha o arrastão chegando no mar sem fim } \\
\text { (11) } a\end{array}$ & Frase $a$ \\
\hline Ê meu irmão me traz Iemanjá pra mim (11) $a$ & Frase $a$ (repetição literal) \\
\hline $\begin{array}{l}\text { Olha o arrastão chegando no mar sem fim } \\
\text { (11) } a\end{array}$ & Frase $a$ (repetição literal) \\
\hline E meu irmão me traz Iemanjá pra mim (11) $a$ & Frase $a$ (repetição literal) \\
\hline
\end{tabular}

Tab.5.9 Arrastão: refrão.

Parte C (Estrutura ternária irregular)

A terceira parte é uma estrutura ternária irregular formada por ter duas frases, sendo a última constituída de três compassos, e não de dois como nas duas semi-frases que formam a primeira frase. Percebe-se que este fato é correspondido pela métrica do último verso. Além disso, a estrutura ternária é correspondida pela organização dos versos em terceto.

\begin{tabular}{|lll|lr|}
\hline Minha Santa Bárbara & (4) & $a$ & Frase $a$ : semifrase $a$ & \\
\hline Me abençoai & $(4)$ & $b$ & “ “ semifrase $a$ ’ & $1-7$ \\
\hline Quero me casar com Janaína & (9) & $c$ & Frase $b$ (3 compassos) & 1 - \\
\hline
\end{tabular}

Tab.5.10 Arrastão: seção C. 
Forma do Arranjo

É importante ressaltar aqui a estrutura formal do arranjo. Muitas vezes tal estruturação não é feita pelo autor da canção, mas, sim, pelo arranjador que no caso é o músico Luiz Eça. Percebe-se algo entre uma forma rondó ou uma forma espelhada ainda que, de fato, nenhuma dessas possibilidades se configure:

Introd. (8 compassos) A B C A B (andamento desdobrado) Fade out.

\subsubsection{Chegança (Edu Lobo e Oduvaldo Viana)}

Esta canção também consta do primeiro long playing de Edu Lobo. Trata-se de uma canção temática sobre os retirantes nordestinos escrita para teatro. É possível que o título remeta ao auto popular brasileiro do ciclo natalino realizado no Nordeste (Câmara Cascudo faz alusões a Alagoas, Paraíba e Rio Grande do Norte ${ }^{116}$. Nesse caso, a chegada dos retirantes nordestinos seria análoga à chegada dos mouros.

\section{Introdução}

Do ponto de vista harmônico, a introdução compõe o $5^{\circ}$ modo derivado do gênero menor bachiano: um mixolídio com $6^{\mathrm{a}}$ menor. Isto devido ao paralelismo da $3^{\mathrm{a}}$ inversão do acorde dominante, somando as notas dos acordes se tem: A/G - sol la do\# mi; G/F - fa sol si re = la si do\# re mi fa sol, levando-se em conta que a priorização se dá em torno da fundamental lá. Somente no último compasso o paralelismo é ascendente, colocando-se em evidência a nota re\# e, nesse compasso, o modo resultante seria o $4^{\circ}$ daquele mesmo gênero: o modo mixolídio com $4^{\mathrm{a}}$ aumentada na soma dos acordes. ${ }^{117}$

\footnotetext{
${ }^{116}$ CASCUDO, 2002, p. 129.

${ }^{117}$ É interessante notar a semelhança do ritmo dessa introdução com o “toque” do Berimbau, em Baden.
} 


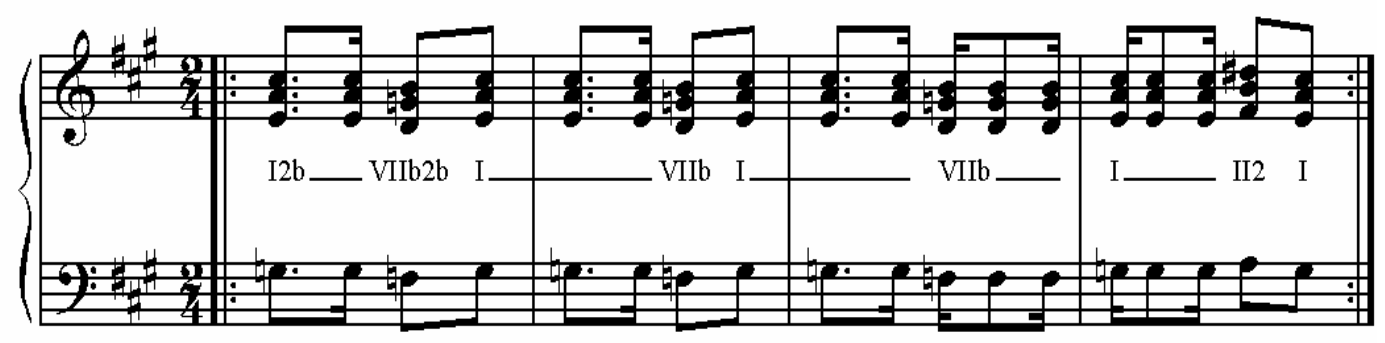

Ex. 5.11 Chegança: Introdução.

Harmonia Parte A: Frase $a$

A melodia deste trecho ocupa a tessitura de um pentacórdio. Entretanto, trata-se de um pentacórdio derivado do $4^{\circ}$ grau da escala diatônica pura (lídio), já que ele possui a $4^{\mathrm{a}}$ aumentada. A harmonia repete os acordes A (lá maior) e B/A (si maior com baixo em lá), o que completa parcialmente o modo com a nota fá\#, deixando em aberto se o modo completo seria o $4^{\circ}$ da referida escala diatônica (lídio, com sol\#) ou de uma escala diatônica híbrida (mixolídio com $4^{\mathrm{a}}$ aumentada, com sol natural).

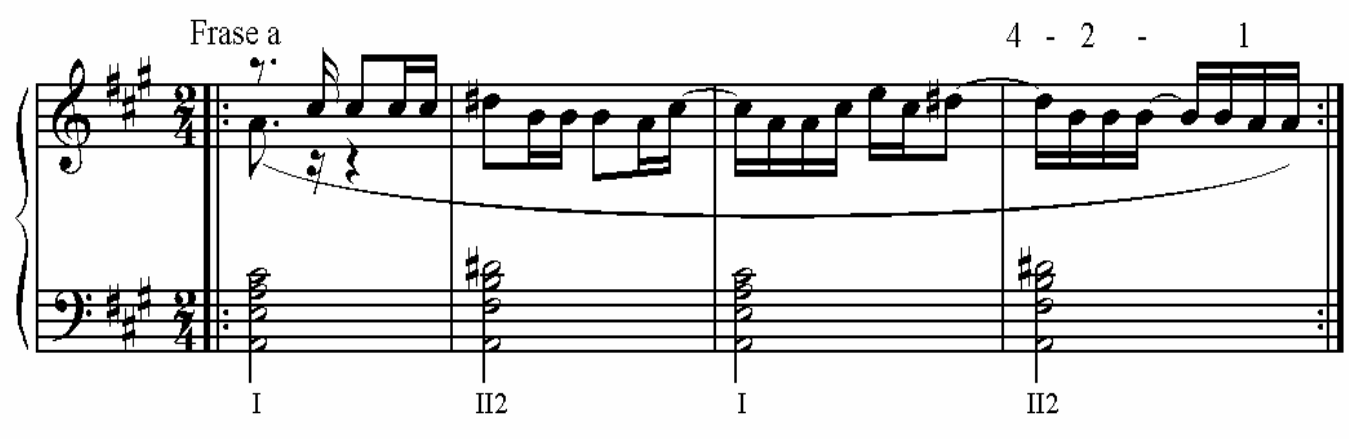

Ex. 5.12 Chegança: frase $a$ da seção A.

Parte A: Frases $b$ e $c$

A frase $b$ é harmonizada com uma série de cadências II - V que se dirigem ao I grau, por isso, de tendência mais tonal. No entanto, a última frase retoma a seqüência original. Mas aqui o acorde de Lá maior apresenta a $7^{\mathrm{a}}$ menor no baixo, explicitando o $4^{\circ}$ modo da escala diatônica híbrida (mixolídio com $4^{\mathrm{a}}$ aumentada). 

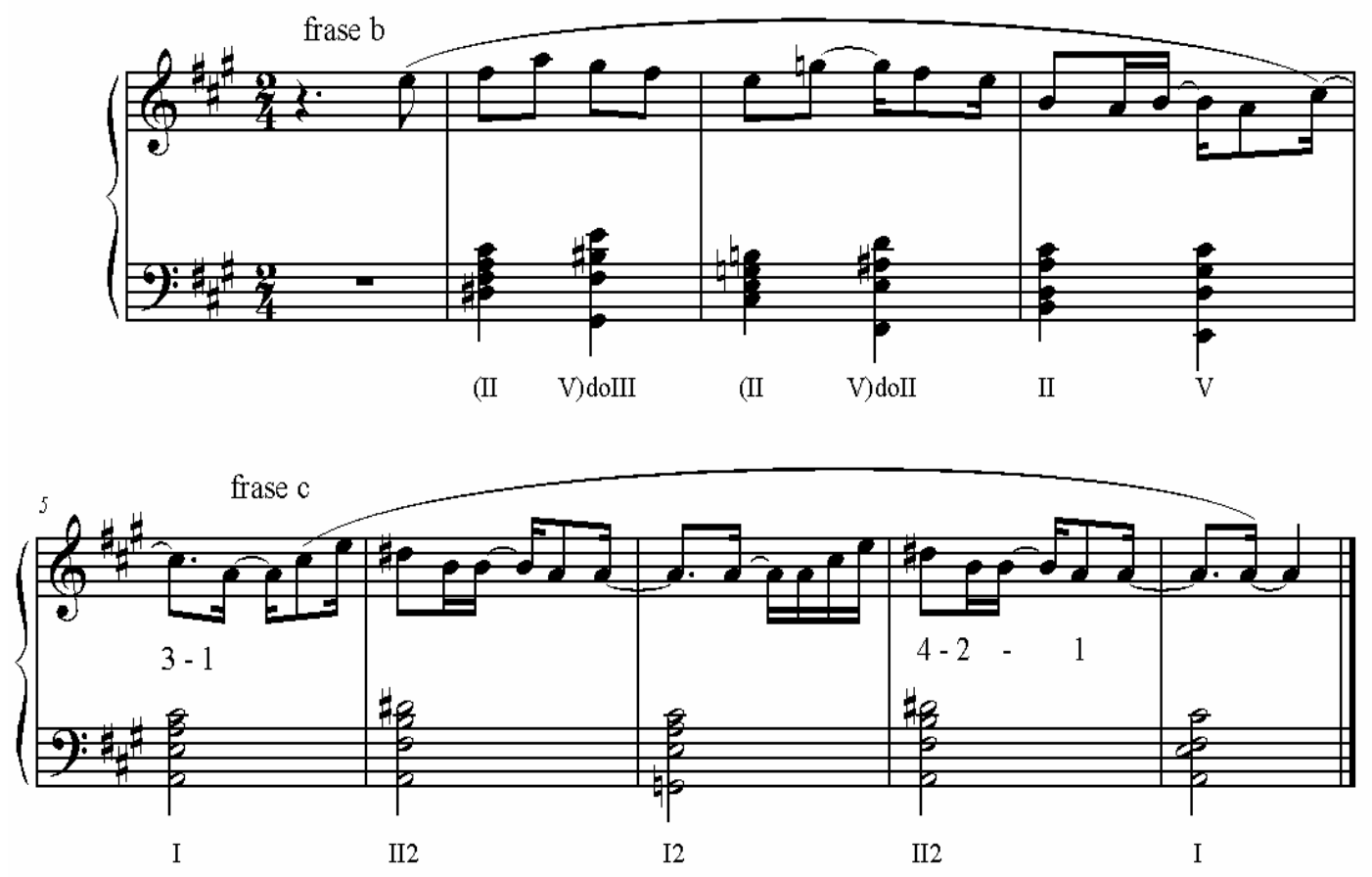

Ex. 5.13 Chegança: frases $b$ e $c$ da seção A.

\section{Parte C}

A última seção apresenta a seqüência ou vamp I (maior) - V(menor), mesma seqüência de Upa, Neguinho, do mesmo autor (com letra de Gianfrancesco Guarnieri), apresenta, como resultante, o $5^{\circ}$ modo da escala diatônica simples (mixolídio), em lá.

etc.

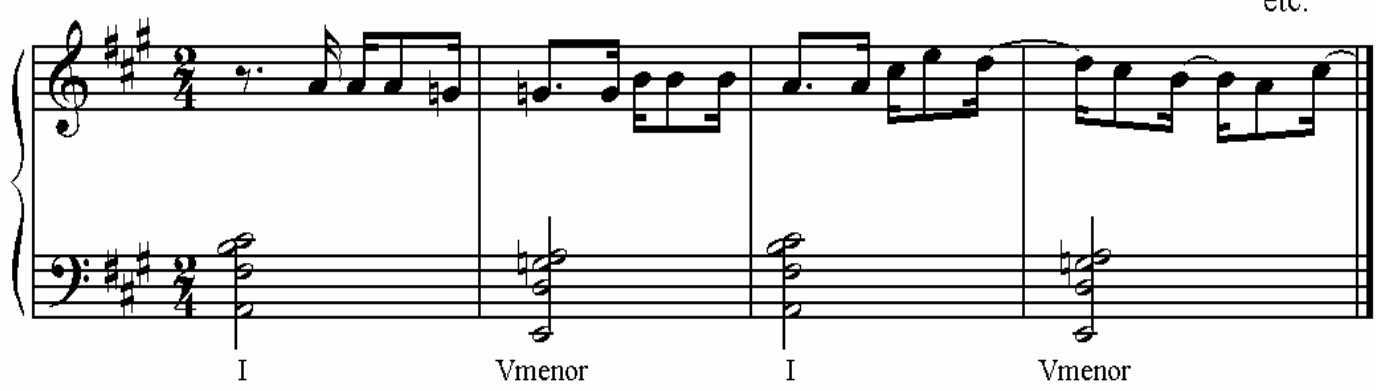

Ex. 5.14 Chegança: trecho da seção C. 


\section{Parte A:}

A primeira parte de Chegança compõe uma sentença regular: dois versos correspondem a uma frase musical e a repetição literal da frase $a$ em caráter de responsório é também enfatizada pela mesma rima.

A terceira frase $b$, frase de contraste, perfaz as rimas $c$ e $d$, cujo $c$ é repetido (também em responsório) na última frase que compõe a seção na forma de cadência. A rigor só há cinco versos; entretanto, eles se repetem nos responsórios para complementar a quadratura fraseológica.

\begin{tabular}{|c|c|c|}
\hline Estamos chegando, daqui e dali (11) $a$ & Frase $a$ : & \\
\hline $\begin{array}{l}\text { E de todo lugar, que se tem pra partir } \\
\qquad \text { (12) } a\end{array}$ & (4 compassos) & $4-2-1$ \\
\hline Estamos chegando, daqui e dali & Frase $a$ : repetição & \\
\hline E de todo lugar, que se tem pra partir & (4 compassos) & \\
\hline Trazendo na chegança & Frase $b$ : & \\
\hline Foice velha, mulher nova & (4 compassos) & $3-1$ \\
\hline E uma quadra se esperança & Frase $c$ (cadência) & \\
\hline E uma quadra se esperança & (4 compassos) & $4-2-1$ \\
\hline
\end{tabular}

Tab.5.11 Chegança: seção A.

\section{Parte B}

A segunda parte pode ser considerada aquilo que Schoenberg chama de Seção Média Contrastante, ou seja, uma seção que não chega a concluir completamente um período, uma sentença ou uma estrutura ternária, apenas duas frases é suficiente para encerrar a idéia. Normalmente, tais seções estão na mesma tonalidade da seção principal ou são modulantes, sem que se chegue efetivamente a uma nova tonalidade ${ }^{118}$.

\begin{tabular}{|lll|ll|}
\hline Ah, se viver fosse chegar & (8) & $a$ & Frase $a$ \\
\hline Ah, se viver fosse chegar & & $a$ & Frase $a^{\prime}$ & $7+1+6$ \\
\hline
\end{tabular}

Tab. 5.12 Chegança: seção B.

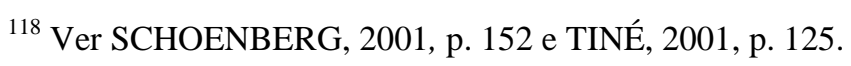




\section{Parte C}

Entretanto, a seção B não conduz à volta da seção A. Do ponto de vista do plano das tonalidades (modalidades?) há uma volta à tônica central (lá), ainda que esses planos sejam enfatizados sem o recurso das dominantes. Nesta última parte observa-se uma sentença que é irregular apenas do ponto de vista fraseológico já que a quadratura é de oito compassos.

\begin{tabular}{|lll|lr|}
\hline Chegar sem parar & (5) & $a$ & Frase $a$ & \\
\hline Parar pra casar & (5) & $a$ & “ & \\
\hline Casar e os filhos espalhar & (8) & $a$ & Frase $b$ & $1+3$ \\
\hline Por o mundo num tal de rodar & (9) & $a$ & Frase $c$ & \\
\hline Por o mundo num tal de rodar & & a & Frase $c$ (cadência) & $4-2$ - 1 \\
\hline
\end{tabular}

Tab.5.13 Chegança: seção C. ${ }^{119}$

\section{Forma do Arranjo}

Também de Luiz Eça, esse arranjo faz uma distribuição bastante interessante dos elementos da canção: as frases $a$ da seção A são repetidas quatro vezes e as frases $b$ e $c$ se repetem proporcionalmente, perfazendo um conjunto de oito frases. Há um interlúdio instrumental que retoma a introdução, a seção A e a seção B dobrada (quatro frases). A recapitulação, em vez de continuar a forma com a seção $C$ que se seguiria à parte $B$, retoma 0 B em seu tamanho original para, então, seguir para $C$ e voltar à introdução com função de coda:

\section{Exposição:}

Introd.(8compassos) A (frases: $a a a a b c b c)$ B $(a b)$ C ( $a a b c c)$

Interlúdio instrumental:

Introd. (8 c.) A (solo de piano na frase a) B (solo de flauta nas frases $a b a b$ )

Recapitulação:

B (canto retoma as frases $a b)$ C (aabcc) Introd. como coda

\footnotetext{
${ }^{119}$ Observa-se aqui o mesmo final cadencial do $4^{\circ}$ modo (lídio), encontrado em Upa, Neguinho, do mesmo autor, na melodia de capoeira Tava lá em Casa, analisada neste trabalho, e Canção do Sal, de Milton Nascimento, que será apresentada mais adiante.
} 


\subsubsection{Borandá (Edu Lobo)}

Outra canção do primeiro long playing de Edu Lobo. Também de inspiração musical e temática nordestinas, trata de emigração. Entretanto não trata da chegada, mas da retirada dos emigrantes. Também traz a crítica a certo tipo de religiosidade característica do Nordeste brasileiro que vê as soluções de problemas pragmáticos na oração e na prece, como no caso do culto dos cantadores a Padre Cícero. Também trata da nostalgia que aquelas pessoas sentem ao deixar seu lugar de origem.

\section{Introdução e Refrão}

A melodia da introdução está baseada no $5^{\circ}$ modo do gênero pentatônico. Observa-se claramente a resolução $7+1$, sol natural lá, se dá três vezes durante este trecho, do $2^{\circ}$ para o $3^{\circ}$ compasso, do $6^{\circ}$ para o $7^{\circ}$ e no $7^{\circ}$ compasso. Tal resolução é de forte caráter modal, pois evita a sensível e sua ascensão para a tônica. A harmonização para o trecho correspondente oscila entre o $2^{\circ}$ modo da escala maior (dórico), pelo uso da nota fa\# no acorde de D7(9), e o $6^{\circ}$ modo da mesma escala (eólio), devido à cadência final com o acorde de Fá maior (F).

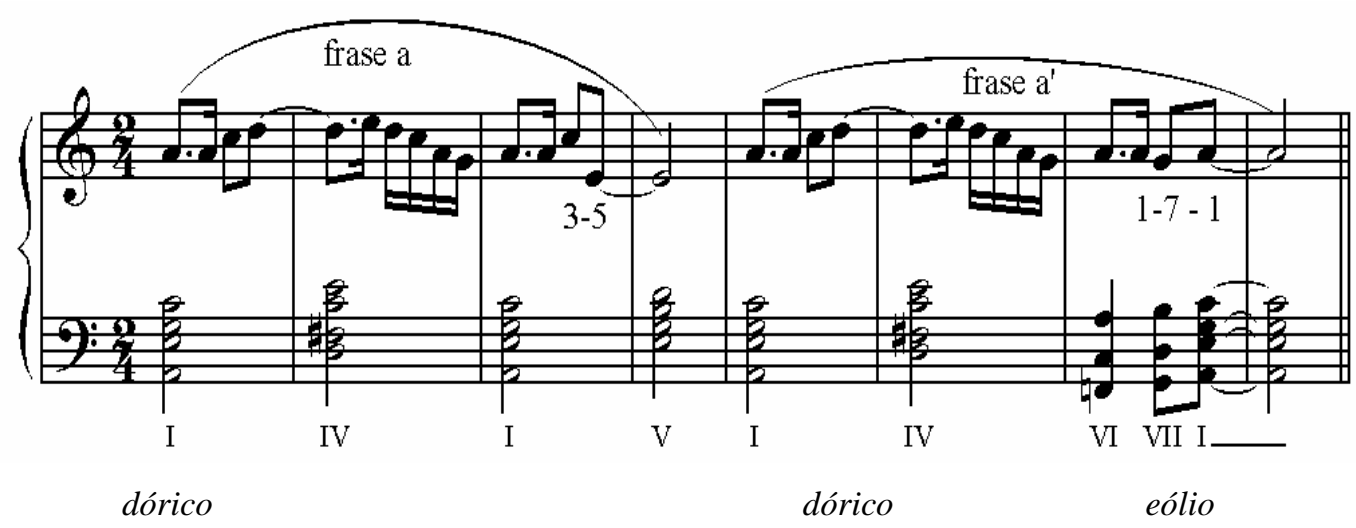

Ex. 5.15 Borandá: refrão.

Parte A

A seção A apresenta uma melodia que oscila entre os modos 6 (eólio) e o 2 (dórico: fá natural do compasso 14 e fá\# do c.16). Harmonicamente, entretanto, uma série de cadências tonais se apresentam. Observa-se no compasso 10 a harmonização da nota sol natural, que se trata de uma sensível modal em ambos os modos mencionados, como $9^{\text {a }}$ aumentada do acorde de dominante (E7) de lá menor. Um modalismo melódico harmonizado tonalmente via notas 
de extensão dos acordes característicos do jazz e bossa nova. Entretanto, tal harmonização corresponde àquela feita no songbook do autor, não correspondendo à da gravação original, que é feita pelo $\mathrm{V}$ menor não dominante (Em7). Outras priorizações tonais harmônicas ocorrem, como as cadências II - V do VI (c.12) e do I (c.14) ${ }^{120}$. Do compasso 16 ao c.21 não ocorrem mais cadências tonais. Nota-se um IV (maior) - V (menor) no c.16 e V (menor) - VII (acorde maior derivado da escala menor natural) no compasso 20, cadências de priorizações modais.

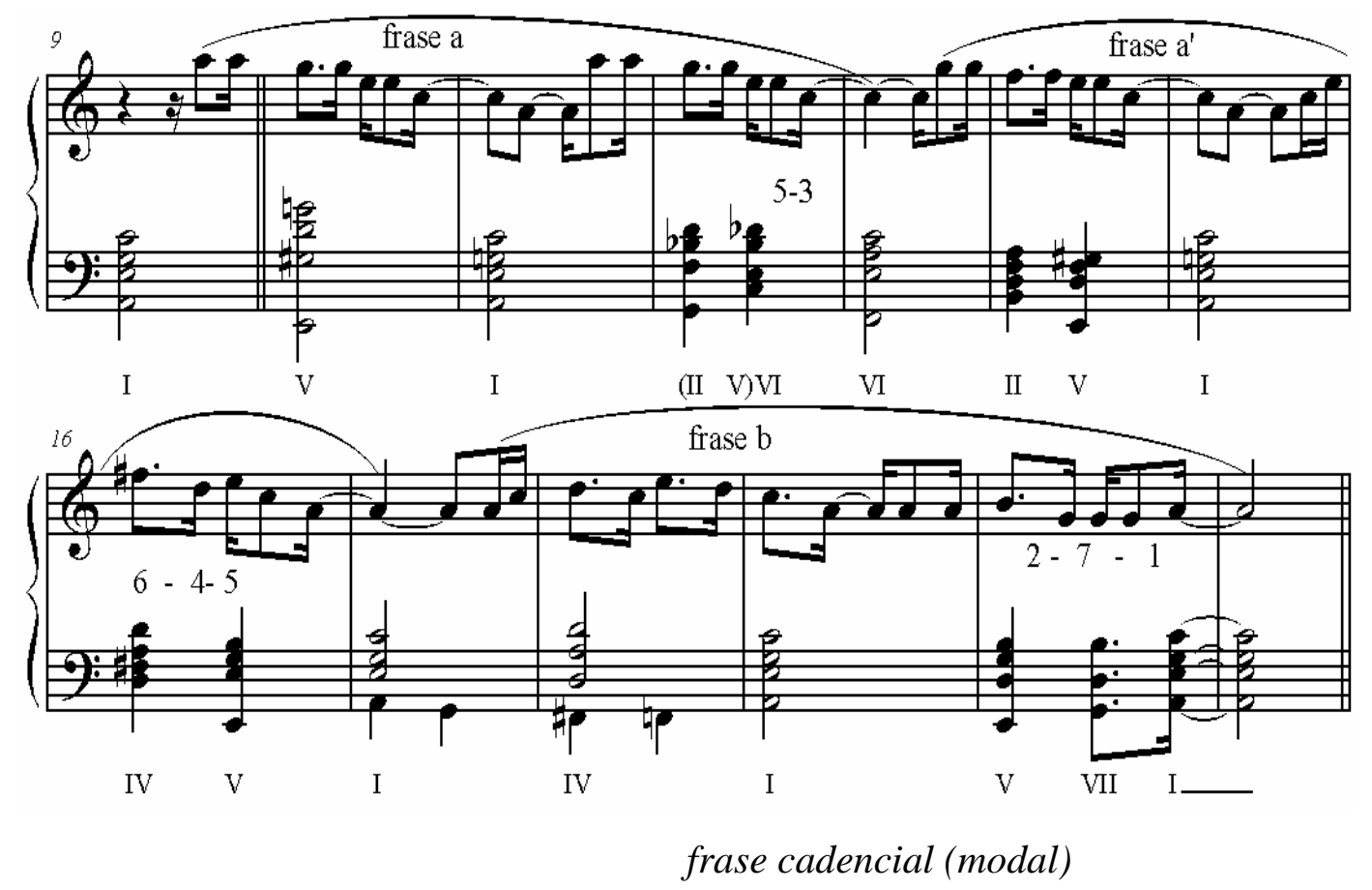

Ex. 5.16 Borandá: seção A.

Parte B

A seção B de Borandá é constituída apenas por duas frases. Trata-se de uma harmonia em constante digressão, mas que não estabelece uma modulação fixa em uma região determinanda. Tais elementos também caracterizam a seção média contrastante. A seqüência Gm/F - Gm6(9) parodia a cadência II - V, neste caso secundária e o Fm7 é o II correspondente do subV (Ger), daí a análise Sub II - V.

\footnotetext{
${ }^{120}$ Fato que não ocorre na gravação original, apenas no songbook (Edu Lobo, 1994).
} 


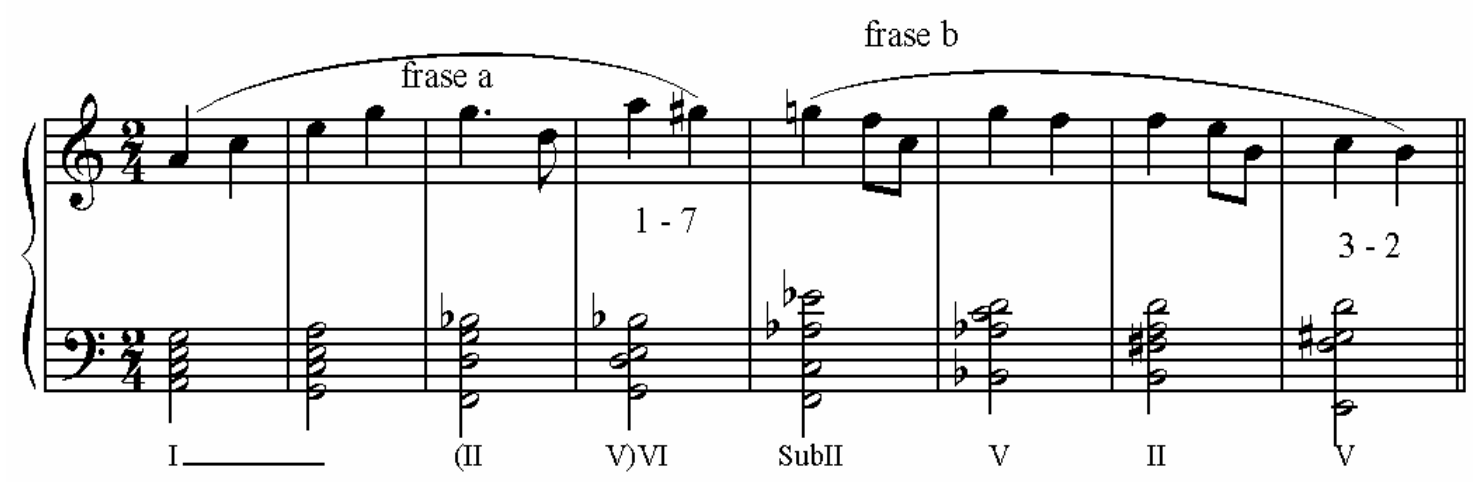

Ex. 3.17 Borandá: seção B.

Introdução e Refrão

A introdução desta canção já traz o mote do refrão com a contração das palavras embora + andar que compõe o seu título.

\begin{tabular}{|c|c|c|lr|}
\hline Letra & Métrica & Rima & \multicolumn{2}{|c|}{ Frases } \\
\hline $\begin{array}{c}\text { Vam’ borandá que a terra já secou, } \\
\text { borandá }\end{array}$ & 13 & $*$ & Frase $a$ & $3-5$ \\
\hline $\begin{array}{c}\text { É borandá que a chuva não chegou, } \\
\text { borandá }\end{array}$ & 13 & $*$ & Frase $a$ & $1-7-1$ \\
\hline
\end{tabular}

Tab.5.13 Borandá: refrão.

Parte A: Estrutura Ternária

Já a seção A é inteiramente constituída por redondilhas maiores. Embora se trate poeticamente de uma quadra com a repetição em responsório dos dois últimos versos, as frases musicais são diferentes nessa repetição, compondo uma estrutura ternária (doze compassos).

\begin{tabular}{|c|c|c|r|r|}
\hline Já fiz mais de mil promessas & 7 & $a$ & semifrase $a$ & Frase $a$ \\
\cline { 1 - 4 } Rezei tanta oração & 7 & $b$ & semifrase $a^{\prime}$ & $5-3$ \\
\hline Deve ser que eu rezo baixo & 7 & $c$ & semifrase $a^{\prime}$ & Frase $a^{\prime}$ \\
\hline
\end{tabular}




\begin{tabular}{|c|c|c|r|r|}
\hline Pois meu Deus não ouve não & 7 & $b$ & semifrase $b$ & $6-4-5^{121}$ \\
\hline Deve ser que eu rezo baixo & 7 & $*$ & semifrase $c$ & Frase $b$ \\
\cline { 1 - 4 } Pois meu Deus não ouve não & 7 & $*$ & semifrase $c$ & (cad.Modal) \\
$2-7+1$ \\
\hline
\end{tabular}

Tab.5.14 Borandá: seção A.

Parte B

A seção B também forma uma seção média contrastante, já que é composta por apenas duas frases.

\begin{tabular}{|c|c|c|c|c|}
\hline Letra & Métrica & Rima & \multicolumn{2}{|c|}{ Frases } \\
\hline Vou me embora & 3 & $a$ & semifrase $a$ & Frase $a$ \\
\hline Vou chorando & 3 & $b$ & semifrase $b$ & $1-7$ \\
\hline Vou me lembrando & 4 & $b$ & semifrase $c$ & Frase $b$ \\
\hline Do meu lugar & 4 & $c$ & semifrase $c$ & $3-2$ \\
\hline
\end{tabular}

Tab.5.15 Borandá: seção B.

Forma da Gravação

A forma da gravação desta canção se dá da seguinte maneira:

introd. - Refrão (2x) - A - Refrão - B - Refrão' (rearmonizado) - Improviso de Piano no vamp ${ }^{122}$ Im7 - IV7 (16 compassos com a cadência modal do refrão) - A - Coda.

\subsection{Milton Nascimento}

\subsubsection{Morro Velho (Milton Nascimento)}

Esta canção consta do primeiro long playing, Milton Nascimento, de 1967, título homônimo ao nome do artista. Milton foi o grande destaque do $2^{\circ}$ FIC-Festival Internacional

\footnotetext{
${ }^{121}$ Nesse ponto não foram escolhidas as notas cadenciais, mas exatamente o ponto melódico da frase que caracteriza o modo. Ver Ex. 16.

122 Sequiência de dois acordes. Ver definição nas Considerações Parciais deste capítulo.
} 
da Canção, sediado no Rio de Janeiro. Sua canção Travessia foi a $2^{\mathrm{a}}$ colocada e se tornou um dos clássicos da música popular brasileira. Diferentemente dos álbuns utilizados anteriormente, este não foi lançado pelo selo “Elenco”, mantendo-se, entretanto, o arranjador: Luiz Eça.

\section{Harmonia parte A:}

A harmonia da seção A apresenta uma seqüência mista (ou híbrida), tal como se viu em Edu Lobo, cercado por trechos tonais. Há três repetições da seqüência A7M - Am7, sendo que o primeiro acorde pertencente ao $4^{\circ}$ modo do gênero diatônico puro (lídio) devido ao uso da nota ré\# na terceira repetição da seqüência e o segundo ao $2^{\circ}$ ou $6^{\circ}$ modo (dórico ou eólio), pois não há uso de fá ou fá\#. A harmonia segue tonalmente com a cadência secundária (II V) em direção ao IV grau. Porém, no lugar do IV grau, há um representante seu: o IV+ meio diminuto. Neste ponto há um choque entre a fundamental do acorde (re\#) e a passagem melódica por ré natural, após o que há o clássico IV menor com 6aa a Subdominante Menor, acorde do chamado empréstimo modal (do modo menor). Os versos $c$, correspondentes às semifrases $c$ e $c$ '(frase $c$ ), assentam-se na volta à seqüência de mista (maior/lídio - menor). Melodicamente há um misto dos modos do $5^{\circ}$ grau da escala diatônica pura (mixolídio) e $4^{\circ}$ da escala diatônica híbrida (mixolídio com $4^{\mathrm{a}}$ aumentada), pois a $7^{\mathrm{a}}$ ( $\mathrm{sol}$ ) é sempre natural. A nota fá natural do sexto compasso é apenas o indicativo da subdominante menor.
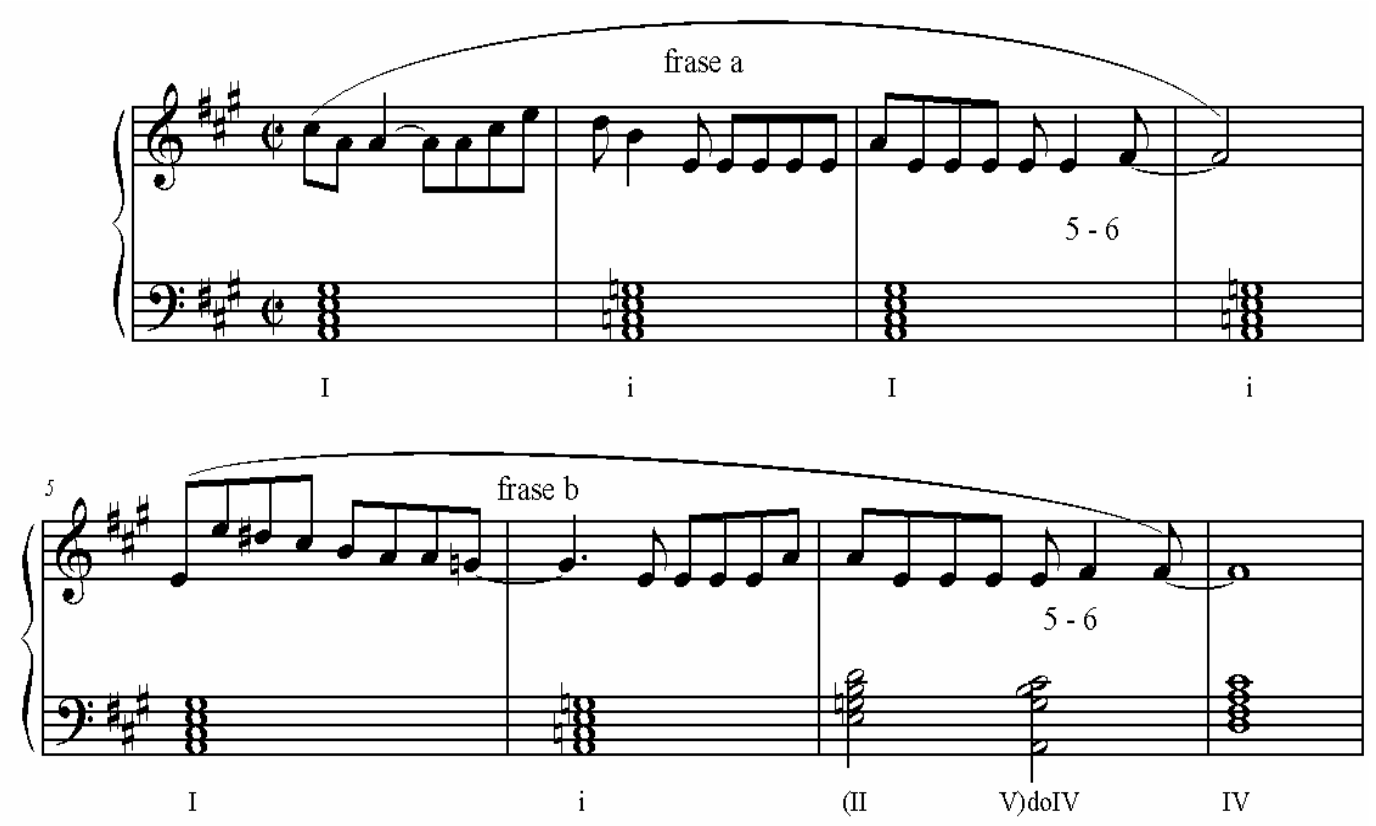
Ex. 5.18 Morro Velho: antecedente de A. ${ }^{123}$
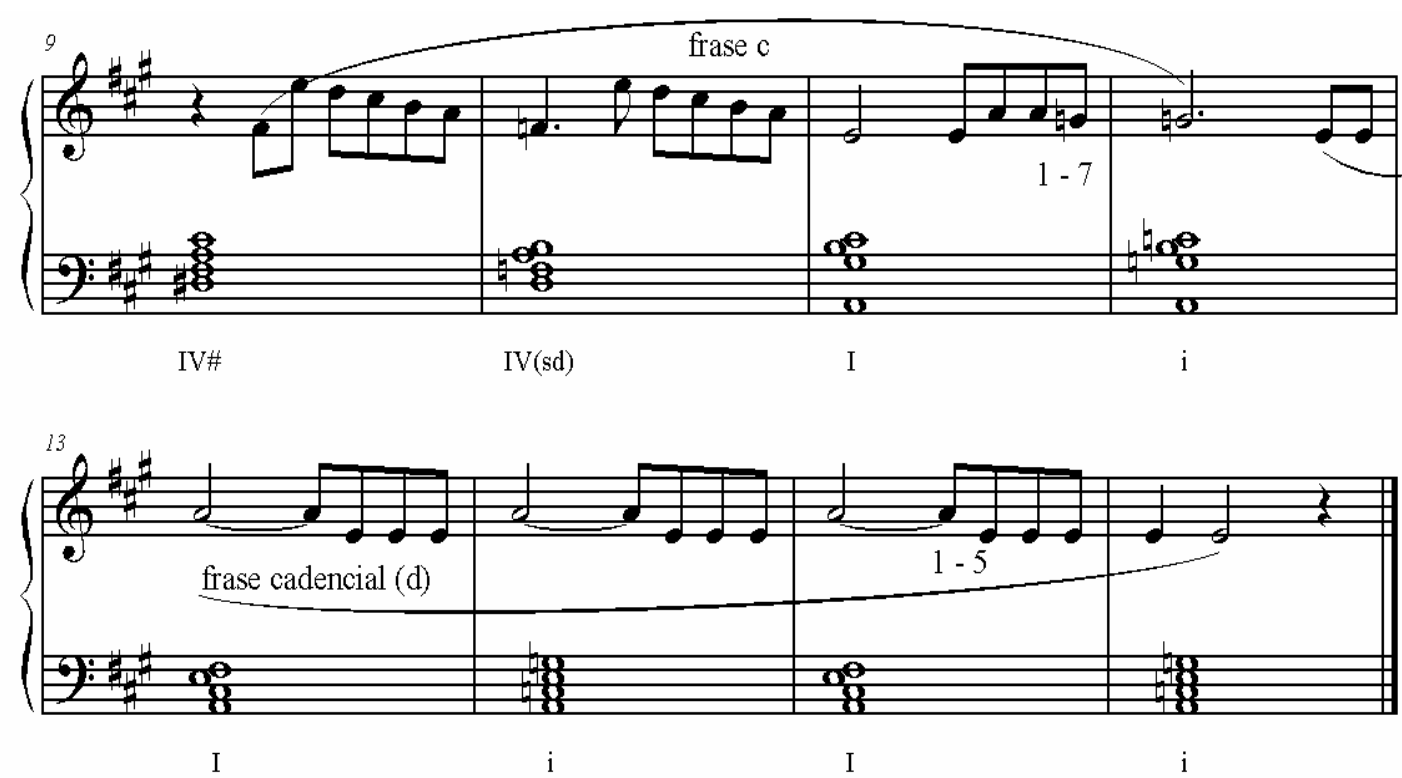

Ex.5.19 Morro Velho: conseqüente de A.

Parte B: antecedente

A segunda parte também é feita de seqüências mistas: a primeira, uma oscilação entre dois acordes menores com $7^{\mathrm{a}}$ menor distantes a um intervalo de $3^{\mathrm{a}}$ menor um do outro (F\#m7 - Am7) nos dois primeiros compassos, e outra que oscila uma $2^{\mathrm{a}}$ maior nos dois últimos compassos (F\#m7 - Em7). O fá\# parece ser priorizado como centro, sem o auxílio de dominantes individuais. A melodia se assenta no $2^{\circ}$ modo da escala pentatônica (fá\# lá si do\# mi), com finalização na $5^{\mathrm{a}}$ justa abaixo e, antes dela, uma blue note além da escala: dó natural que se ajusta ao acorde do momento: Am7.

${ }^{123}$ A transcrição melódica desta canção é apenas uma aproximação simplificada do ponto de vista rítmico devido a inúmeras variações interpretativas realizadas pelo autor-intérprete durante a execução na gravação de referência. 


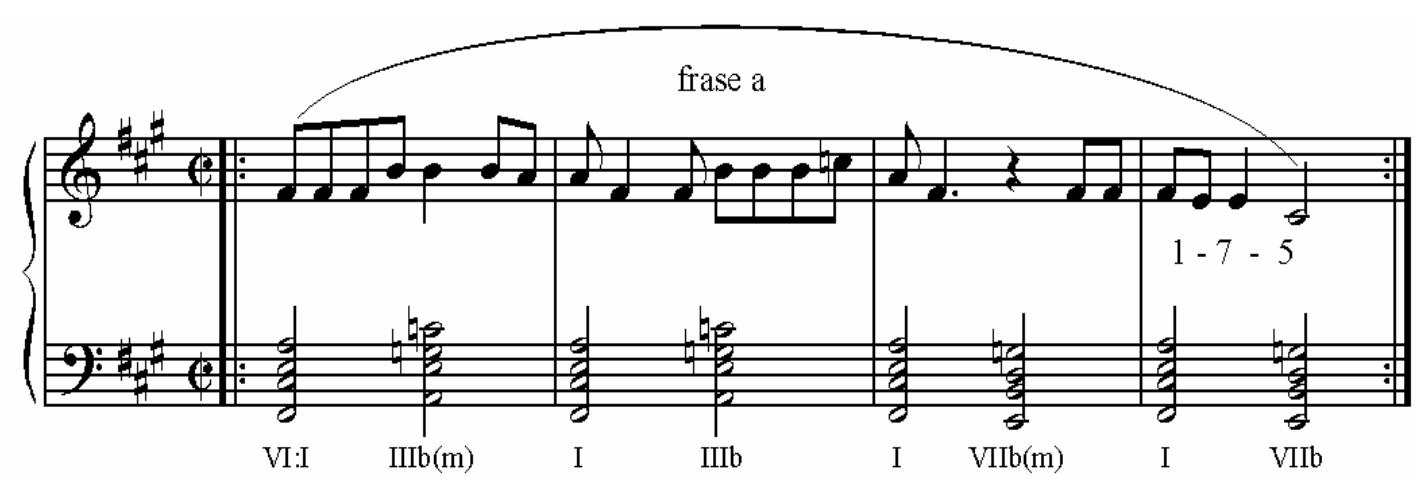

Ex. 5.20 Morro Velho: antecedente de B.

Parte B: conseqüente

Já o conseqüente de B se constitui com uma seqüência cromático-descendente, cujo final se dá, quando da primeira vez, em fá\#: A7M - G\#m7 - G7M - F\#m7. Mesmo se tratando de uma seqüência maior, o final IIb - I, com o uso do acorde napolitano, está entre aqueles desaconselhados por Schoenberg na construção de exercícios, por se tratar de uma finalização plagal ${ }^{124}$. É apenas na repetição que a resolução é substituída pela cadência II - V em direção à priorização principal da seção A: lá maior.

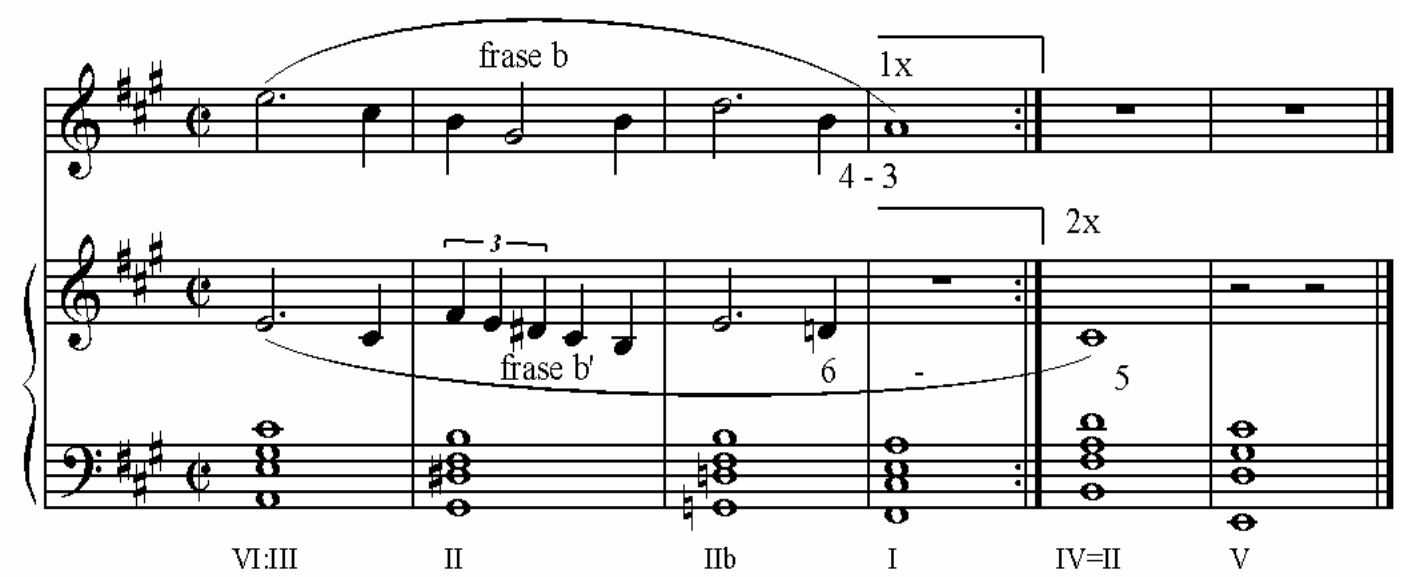

Ex. 5.21 Morro Velho: conseqüente de B.

Parte A: antecedente

124 “As cadências plagais IV - I, II - I e a cadência frígia II - III [...] são apenas uma meio de expressão estilístico e não possuem nenhuma importância estrutural.” (SCHOENBERG, 2004, p.32) 
No caso desta canção, o verso corresponde à semifrase; portanto, a primeira quadra corresponde ao antecedente. Há uma correspondência alternada entre as rimas e as semifrases, além de uma regularidade oscilante da métrica entre versos de 7 e 11 sílabas.

\begin{tabular}{|c|c|c|}
\hline No sertão da minha terra $\quad$ (7) $a$ & Frase $a$ & \\
\hline $\begin{array}{l}\text { Fazenda é o camarada que ao chão se deu } \\
\text { (11) } b\end{array}$ & “........." & $5+6$ \\
\hline $\begin{array}{lll}\text { Fez a obrigação com força } & \text { (7) } c\end{array}$ & Frase $b$ & \\
\hline $\begin{array}{l}\text { Parece até que tudo aquilo ali é seu } \\
\qquad(11) b\end{array}$ & “.........." & $5+6$ \\
\hline
\end{tabular}

Tab.5.16 Morro Velho: seção A, antecedente.

Parte A: conseqüente

O conseqüente prossegue a correspondência anterior, aqui não mais alternada mas, sim, direta entre rimas e semifrases. A alternância métrica também prossegue; entretanto, apenas o segundo verso é de 11 sílabas, o restante de 7. Como não há repetição de frase completa, essa estrutura se difere do período e da sentença sem que, apesar disso, figure-se alguma irregularidade, como uma espécie de verso branco musical, ou seja, há uma regularidade de 16 compassos (métrica) sem repetições de frases (rima).

\begin{tabular}{|lrr|ll|}
\hline Só poder sentar no morro & $(7)$ & $a$ & Frase $c$ & \\
\hline E ver tudo verdinho lindo a crescer & & “......... & $1-7$ \\
& $(11)$ & $b$ & & \\
\hline Orgulhoso camarada & $(7)$ & $c$ & Frase Cadencial $(d)$ & 1 - 5 \\
\hline De viola em vez de enxada & $(7)$ & $c$ & “.......... & \\
\hline
\end{tabular}

Tab.5.17 Morro Velho: seção A, conseqüente.

Parte B: antecedente

A parte B mantém a mesma proporcionalidade entre verso poético e frase musical: cada verso corresponde a uma semifrase e a quadra corresponde ao antecedente ou conseqüente. Nos versos rimados há uma correspondência métrica que não ocorre nos versos 1 e 3. 


\begin{tabular}{|lrr|ll|}
\hline Filho do sinhô vai embora & (8) & $a$ & \multicolumn{2}{l|}{ Frase $a$} \\
\hline É tempo de estudo na cidade grande & “ & & \\
& $(12)$ & $b$ & & $1-7-5$ \\
\hline Parte, tem os olhos tristes & $(7)$ & $c$ & Frase $a$ & \\
\hline $\begin{array}{l}\text { Deixando o companheiro na estação } \\
\text { distante }\end{array}$ & (12) & $b$ & & \\
\hline
\end{tabular}

Tab.5.18 Morro Velho: seção B, antecedente.

Parte B: conseqüente

Feita de versos curtos, o conseqüente da seção B tem um aspecto mais emotivo, em que as notas longas se impõem aos motivos rítmicos do antecedente, gerando o contraste. Quando se considera a frase $b$ ' semicadencial - isto é, não leva à conclusão na tonalidade da seção -, pode-se considerar a parte B uma sentença.

\begin{tabular}{|lcc|lc|}
\hline Não me esqueça amigo & $(5)$ & $a$ & Frase $b$ & \\
\hline Eu vou voltar & $(4)$ & $b$ & “ & 4 \\
\hline Some longe o trenzinho & $(6)$ & $c$ & Frase $b$ ’ & \\
\hline Ao deus-dará & $(4)$ & $b$ & “ & “ \\
\hline
\end{tabular}

Tab.5.19 Morro Velho: seção B, conseqüente.

Forma do Arranjo

A estrutura formal do arranjo de Morro Velho não é das mais sofisticadas. Um pequeno refrão é apresentado ao violão, da mesma maneira que no clássico Travessia ${ }^{125}$. Este refrão intermedeia a repetição da seção A, além de ser apresentado ao final com função de coda.

Refrão Instrumental (6 compassos) A Refrão Instr. A B A Refrão como Coda

\footnotetext{
${ }^{125}$ Esse tipo de introdução/refrão, nas cordas primas do violão, parece configurar um recurso bastante utilizado nas composições de Milton. Tal como na próxima canção a ser analisada, Vera Cruz, ou ainda em canções posteriores, como Maria, Maria.
} 


\subsubsection{Vera Cruz (Milton Nascimento e Márcio Borges)}

Esta canção está presente no segundo long playing de Milton, gravado nos Estados Unidos da América em 1968, intitulado Courage. O repertório é praticamente o mesmo do primeiro long playing lançado no Brasil; entretanto os arranjos são de Eumir Deodato, sendo Vera Cruz a única música inédita.

Harmonia da Introdução:

O caráter de instabilidade da introdução deve-se à sua harmonia cromática. Há apenas uma tipologia de acorde até o $7^{\circ}$ compasso da introdução que vai sendo transportado. Tal procedimento parece ser um prolongamento daquele da seção B de Morro Velho.
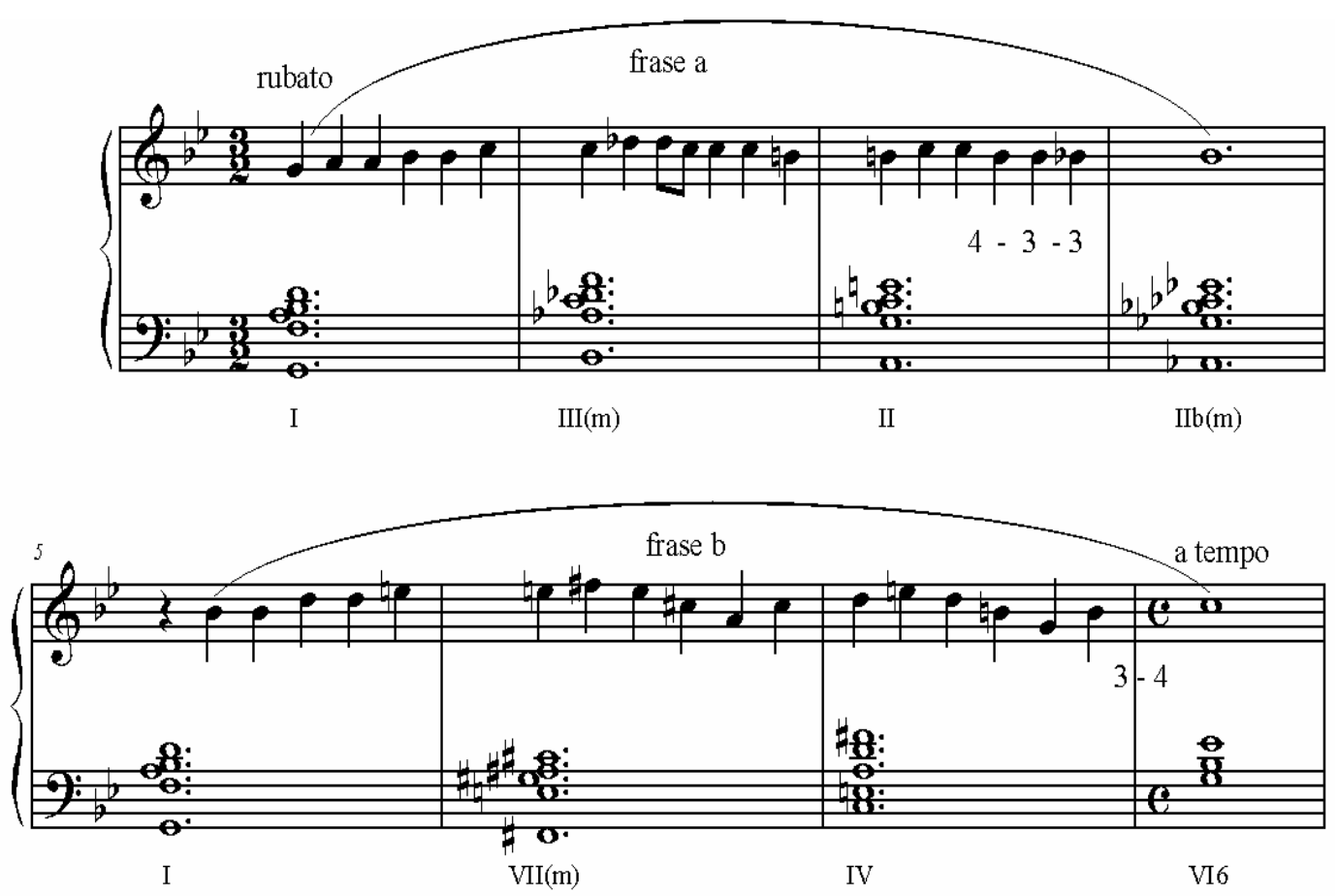

Ex. 5.22 Vera Cruz: introdução.

Parte A:

A estrutura ternária da seção A é tonal, principalmente com a relação dominantetônica do $10^{\circ}$ para o $11^{\circ}$ compasso (V/VI - VI), com uma cadência harmônica "modal” no final: no lugar do V grau dominante, há o V grau menor com o fá natural na melodia. Há também um acorde de empréstimo da tonalidade homônima maior: si menor com $7^{\mathrm{a}}$, III de 
sol maior em sol menor. Observa-se também que a melodia "flutua" nas extensões dos acordes - 9as e 7as -, mas compõe um modo eólio sem nenhuma alteração.
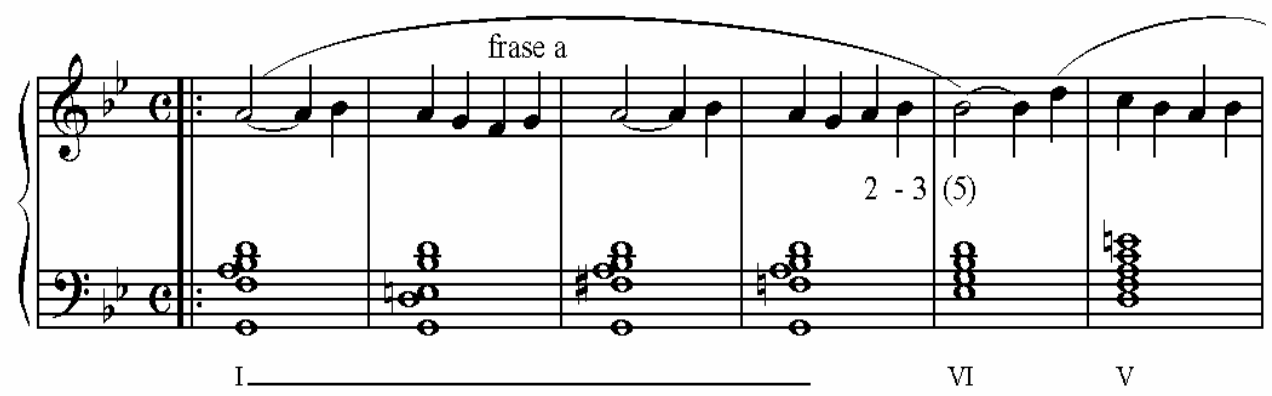

$\mathrm{V}$

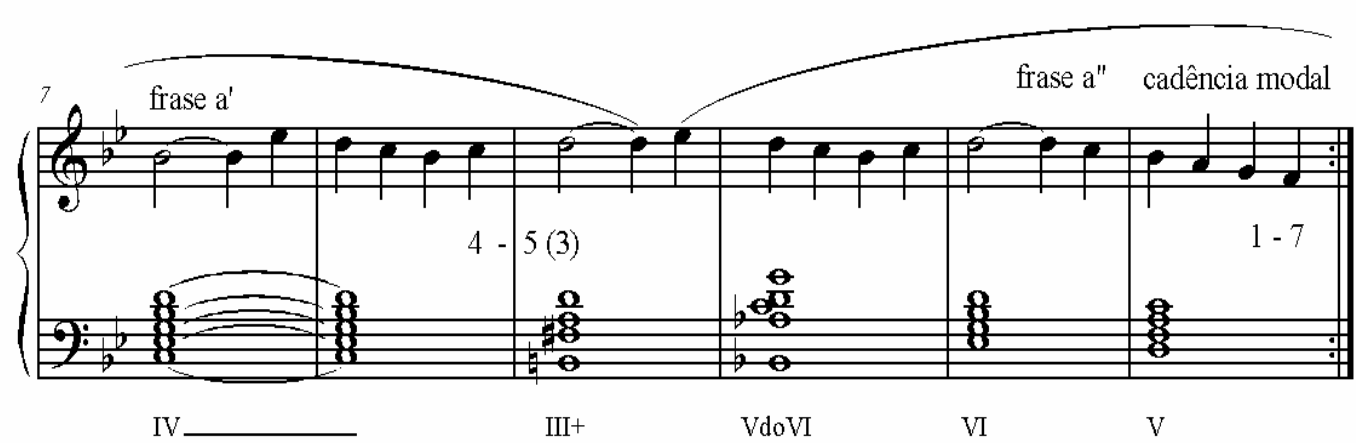

Ex. 5.23 Vera Cruz: seção A.

\section{Introdução}

A introdução tem um caráter instável. Nesse caso, o motivo corresponde ao verso e cada grupo de três versos/motivos compõe uma frase musical. Enquanto os motivos formam, nas duas frases, a estrutura $a b b$, os versos formam $a b c-b d c$. Todos os versos possuem a mesma estrutura métrica.

\begin{tabular}{|c|c|c|c|}
\hline Hoje foi que a perdi & (6) $a$ & Frase a: motivo $a$ & \\
\hline Mas onde, já nem sei & (6) $b$ & “ $\quad$ ": motivo $b$ & \\
\hline Me levo para o mar & (6) & “ “ “: motivo b' & $4-3(9)^{126}$ \\
\hline Em Vera me larguei & (6) $b$ & Frase b: motivo $a^{\prime}$ & \\
\hline E deito nessa dor & (6) $d$ & “ “: motivo $b "$ & \\
\hline Meu corpo sem lugar & (6) $c$ & “ “: motivo b" & $3+4$ \\
\hline
\end{tabular}

Tab.5.20 Vera Cruz: introdução.

\footnotetext{
${ }^{126}$ O parêntese aqui indica que, embora do ponto de vista puramente melódico haja a resolução da quarta diminuta na terça do modo, esta nota, em relação ao acorde daquele compasso, é a nona maior de Abm6.
} 
Parte A:

A seção A é uma Estrutura Ternária por se constituir de 12 compassos formados por três frases $a$, transposta e variada segundo a harmonia. É interessante perceber que, embora a métrica seja regular com os versos correspondendo às semifrases, não há rima, tratando-se, portanto, de verso branco. Já a sextilha e a Estrutura Ternária se correspondem.

Métrica (sem rima)

\begin{tabular}{|lcc|lc|}
\hline (Ah), quisera esquecer & $(6)$ & $a$ & Frase $a$ & \\
\hline A moça que se foi & $(6)$ & $b$ & “ “ & \\
\hline De nossa Vera Cruz & $(6)$ & $c$ & Frase $a$ & \\
\hline E o pranto que ficou & $(6)$ & $d$ & “ & “ \\
\hline Da morte que sonhei & $(6)$ & $e$ & Frase $a$ ” & \\
\hline Nas coisas de um olhar & $(6)$ & $f$ & “ “ & $1-7$ \\
\hline
\end{tabular}

Tab.5.20 Vera Cruz: seção A.

Forma do Arranjo

Introd. - Refrão - Parte A - Refrão A' - Parte A”(ponte) - Introd. - Refrão A Interlúdio Instrumental (A’) - Parte A - Refrão A’(coda).

\subsubsection{Canção do Sal (Milton Nascimento)}

Também gravada no primeiro disco do autor, em 1967, trata-se, assim como Morro Velho, de uma canção de temática social, o que de certa forma conecta Milton com Edu Lobo e a Canção de Protesto, na medida em que essas duas canções - Morro Velho e Canção do Sal - têm a autoria da letra e música assinadas pelo autor. O ponto de vista subjetivo expresso nas duas canções apontam para um aprofundamento psicológico da temática. Isso porque, mesmo que os autores anteriores coloquem os textos em primeira pessoa, Milton se apropria de expressões características do pensamento popular, como, por exemplo, os versos: “que é pra não ter meu trabalho, e vida de gente levar" ou "Filho do Sinhô vai embora, é tempo de estudo na cidade grande”. 


\section{Harmonia versus Melodia}

A seção A trata-se de uma sentença na qual a melodia está composta no $5^{\circ}$ modo da escala diatônica pura (mixolídio), sendo que em sua cadência há a utilização do $4^{\circ}$ grau da escala diatônica híbrida (mixolídio com $4^{\mathrm{a}}$ aumentada). Entretanto, a harmonização é um tanto convencional, dentro de um contexto da era bossa nova, com algumas indicações parecidas com aquelas encontradas em Edu Lobo: I V(não dominante).
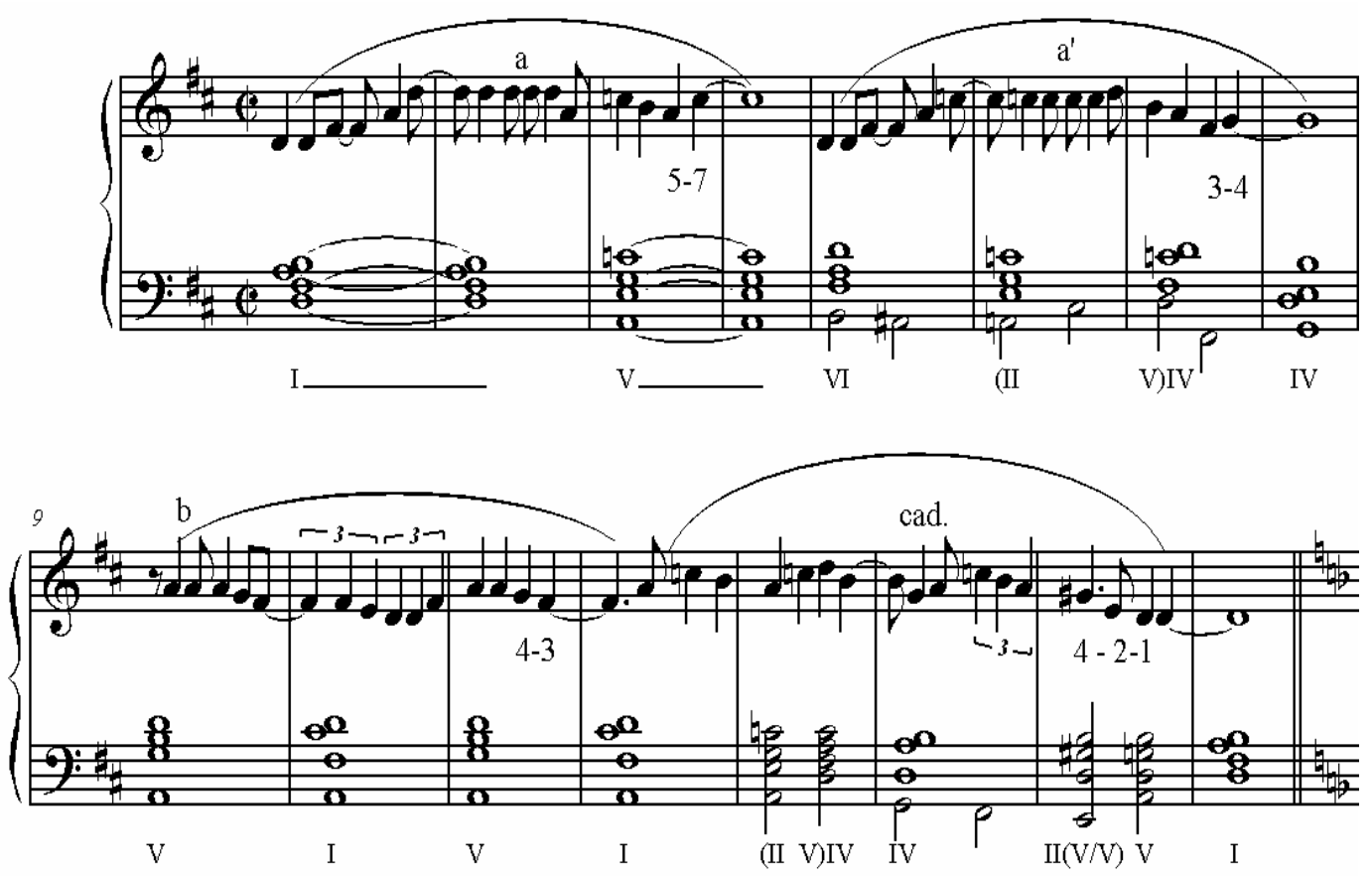

Ex. 5.24 Canção do Sal: seção A.

Já a seção B apresenta uma seqüência harmônica correspondente à semifrase, que realiza um movimento cromático descendente a partir do II grau. Este aparece na forma de dominante secundária (V/V) para se resolver à $6^{\text {a }}$ germânica no acorde napolitano (IIb). Esta seqüência se repete quatro vezes e é muito semelhante àquela da parte $\mathrm{A}$ de Canto de Ossanha (Baden e Vinicius). A melodia é composta pelas notas do arpejo do acorde de Dm7 com $6^{\text {a }}$ maior e menor na semifrase $a$ e com o final 7-1 na semifrase $a^{\text {' }}$. 


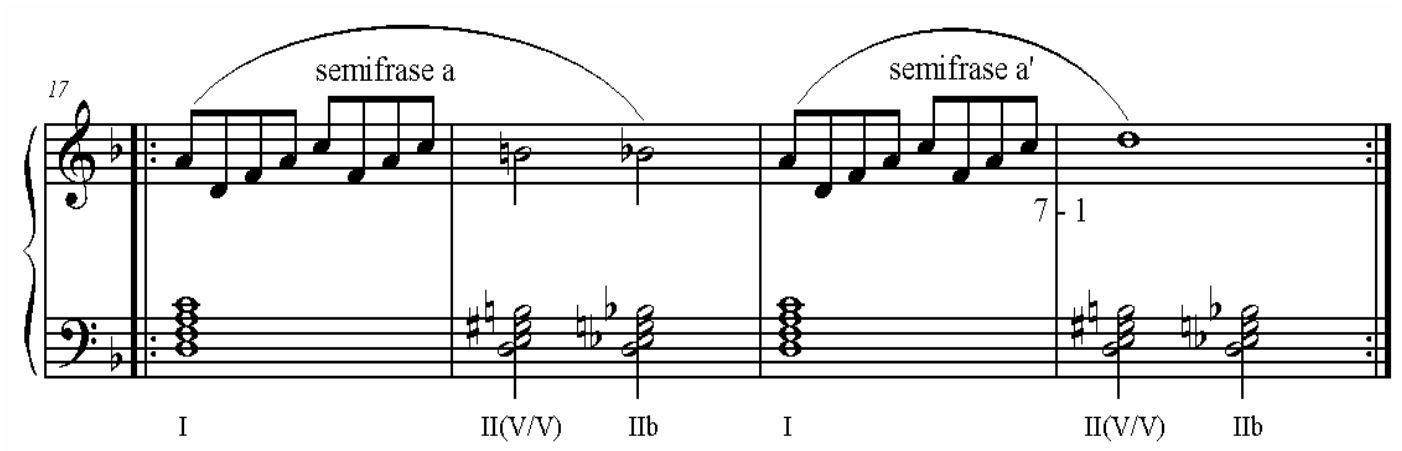

Ex. 5.25 Canção do Sal: seção B.

Como demonstra a tabela abaixo, a seção A de Canção do Sal é uma sentença regular composta pelas frases $a, a^{\prime}, b$ e cadência. A métrica oscila entre versos de 5 e 8 (exceto o $7^{\circ}$ verso) sílabas, mas a rima só ocorre entre o $6^{\circ}$ e o $8^{\circ}$ verso. A estrutura binária da sentença é correspondida pela estrofe de oito versos.

\begin{tabular}{|ll|lr|}
\hline Trabalhando o sal & (5) $a$ & Semifrase $a$ & \\
\hline É o amor, o suor que me sai & (8) $b$ & Semifrase $b$ : frase $a$ & $5+7$ \\
\hline Vou viver cantando & (5) $c$ & Semifrase $a$ ' & $3+4$ \\
\hline O dia tão quente que faz & (8) $d$ & Semifrase $b^{\prime}$ : frase $a^{\prime}$ & $4-3$ \\
\hline Homem vê criança & (5) $e$ & Semifrase $c$ & \\
\hline Buscando conchinhas no mar & (8) $f$ & Semifrase $d$ : frase $b$ & \\
\hline - Trabalho o dia inteiro & (7) $g$ & Semifrase $e$ & \\
\hline - Pra vida de gente levar & (8) $f$ & Semifrase $e$ : frase $c$ (cadência) & 4 \\
\hline
\end{tabular}

Tab.5.21 Canção do Sal: seção A.

A parte B é composta apenas de uma frase musical que se repete literalmente. Como o verso corresponde à semifrase, uma quadra é completada, sendo que os dois últimos versos são letras diferentes para a mesma frase. Trata-se também de uma seção média contrastante.

M R

\begin{tabular}{|l|l|l|ll|}
\hline Água vira sal lá na salina & 9 & $a$ & Semifrase $a$ \\
\hline Quem diminuiu água do mar & 9 & $b$ & Semifrase $a^{\prime} \quad 7+1$ \\
\hline Água enfrenta o sol lá na salina & 9 & $a$ & Semifrase $a$ \\
\hline Sol que vai queimando até queimar & 9 & $b$ & Semifrase $a^{\prime} \quad 7+1$ \\
\hline
\end{tabular}

Tab.5.22 Canção do Sal: seção B. 
Forma do Arranjo

O arranjo dessa canção obedece à disposição abaixo. É interessante notar o jogo entre as tonalidades de ré maior, ré menor e mi maior (que transpõe a seção A um tom acima) que conduz o arranjo.

$$
\text { Introd. A A B A' introd B A' coda }
$$

Tom: D......d E.....D.........................

\subsection{Considerações Parciais}

Das canções analisadas neste capítulo, verificou-se que três seções eram completamente baseadas em seqüências modais (A de Consolação, Berimbau e C de Chegança, ainda que esta seja uma seqüência híbrida) e outras quatro (A de Chegança) parcialmente baseadas sendo, três delas (A e antecedente de B de Morro Velho e B de Arrastão), baseadas em seqüências híbridas. Isto é, os dois acordes da seqüência não pertenciam ao mesmo campo harmônico. Um termo do jargão jazzístico que descreve este procedimento é a já citada palavra vamp:

A short passage, which is simple in rhythm and harmony, played in
preparation for the entry of soloist; it is usually repeated ad libitum until the
soloist is ready, hence the rubric "vamp till ready". The term is applied to the
technique of playing ostinatos before or between solos, and, by extension,
during after solos. [...] In jazz-rock, latin jazz and other fusions of jazz and
popular music, and especially in modal jazz, an entire piece may be based on
a succession of open-ended vamps. (The New Groove Dictionary of Jazz,
1996, p. 1238)

Verificou-se também um outro procedimento que parece ser uma extensão daquele primeiro: uma seqüência de quatro acordes (turnarounds) ${ }^{127}$ que podem até ter relações tonais (Vger. do IIb) internamente, mas não no grau principal polarizado (via de regra com a versão plagal da cadência napolitana: IIb - I), que ocorreram em três seções (A de Canto de Ossanha, conseqüente de B de Morro Velho e B de Canção do Sal).

Houve ainda quatro seções que apresentaram extensas progressões harmônicas, mas que apresentaram cadências modais (Refrão e A de Borandá e A de Vera Cruz e B de

127 "A chord pattern at the end of the final phrase of a chorus, which leads back to the beginning of the theme." (The New Grove Dictionary of Jazz, 1996, 1228) Assim como a palavra vamp, utilize-se aqui o termo turnaround para especificar este procedimento. Ele poderia ser traduzido por "cadência", mais isso só traria confusão em relação ao próximo elemento. 
Consolação), duas harmonizações tonais de melodias modais (B de Berimbau e A de Canção do Sal).

Por fim, seções puramente tonais (B de Canto de Ossanha, C de Arrastão e B de Borandá). A seguir, apresenta-se um resumo dos procedimentos encontrados em graus cifrados, isto é, são estruturas que, a partir de $d o$, valem para diversas tonalidades e para mais de uma seqüência:

1. Seqüências Modais ${ }^{128}$ :

\begin{tabular}{|c|c|c|}
\multicolumn{2}{|c}{ Vamp } & Modo \\
\hline //: Im7 / Vm7 :// & (pentatônico & $5+7$ \\
& com 2a) & $7+1$ \\
\hline //: Im7 IV :// & (dórico) & $3+4$ \\
& & $7-5+6$ \\
\hline //: I6 / Vm7 :// & (mixolídio) & $7+2-1$ \\
\hline //: I / II7 :// & (lídio) & $4-2-1$ \\
\hline //: I7M / Im6 :// & (híbrido) & $3+6$ \\
\hline //: Im7 / IIIbm7 :// & (híbrido) & $7-5$ \\
\hline //: Im7 / VIIbm7 :// & (frígio) & $4+6-5$ \\
\hline //: Isus7(9) / I7M :// & (híbrido) & $7-5+6$ \\
\hline //: Im7 / IIm7 :// & (dórico) & $5-1$ \\
\hline
\end{tabular}

Tab.5.22 Relação Vamp/ Modos/ Cadências Melódicas.

2. Seqüências de quatro acordes (turnarounds):

Turnaround

\begin{tabular}{|c|c|}
\hline //: Im7 / IIIb6 / II7 / IIb :// & $4+5$ e 1 \\
\hline //: IIIb7M / IIm7 / IIb7M / Im7 :// & $4-3$ \\
\hline //: Im7 / II7 IIb7M :// & $7+1$ \\
\hline
\end{tabular}

Tab.5.23 Relação Turnaround/ Cadências Melódicas.

\footnotetext{
${ }^{128}$ Neste ponto os graus não indicam uma análise hamônica, mas uma cifra que valeria para qualquer tonalidade. ${ }^{129}$ Apesar de esse modo não ter sido mencionado na análise de Morro Velho, de Milton Nascimento, a seqüência do final do antecedente da seção B só pode se encaixar nesse modo, pois se estivesse em do, o primeiro acorde seria Cm7 e o segundo Bbm7, ambos pertencentes ao campo de lá bemol maior e, sendo do polarizado como centro, resta considerá-lo pertencente ao $3^{\circ}$ modo do gênero diatônico puro.
} 
Deve-se ressaltar que o uso da seqüência de quatro acordes se deu sempre no modo (tom?) menor.

3. Cadências modais:

Harmônicas

Modo

Melódicas

\begin{tabular}{|c|c|c|}
\hline VI7M - Vm7 - Im7 & (eólio) & $1-7+1$ \\
\hline VI - VIIb - Im & (eólio) & $1-7+1$ \\
\hline Vm7 - VIIb - Im7 & (eólio) & $2-7+1$ \\
\hline Im7 - Vm7 - IIb7M & (híbrido eólio e frígio) & $1-7+1$ \\
\hline
\end{tabular}

Tab.5.24 Relação de Cadências Harmônicas e Melódicas.

As cadências melódicas harmonizadas tonalmente normalmente evitavam a $7^{\mathrm{a}}$, já que esta, dentro do sistema tonal, é uma das caracterizadoras da relação Dominante- tônica: 3 - 2 - 1 (eólio) para a cadência VI(ger. do V) - V - IIb; 4 - 2 - 1 (lídio) II(V do V) - V - I. Mesmo nas seções tonais há a harmonização da cadência $6+1$ (jônio) com a mesma cadência harmônica anterior: II(V do V) - V - I. Essa mesma cadência adaptada à tonalidade menor também harmoniza a cadência melódica 3 - 2. É importante lembrar que na canção Vera Cruz, de Milton Nascimento e Márcio Borges, há uma diferente significação intervalar na relação com o modo no qual a melodia está construída e na função melódica em relação ao acorde que está, normalmente, repousado em tensões distantes na séria harmônica de cada um.

Do ponto de vista da investigação da relação entre estrutura poética e fraseologia, verificou-se que a métrica foi muito mais geradora de rimas musicas, ou seja, repetições de frases, semifrases ou motivos mais do que a própria rima. Há uma correspondência maior entre as métricas e as frases e suas diferenciações e, na maioria dos casos, apenas uma correspondência parcial entre rima e repetição de frase, isto também devido à predominância do canto silábico sobre o melismático. Um exemplo muito interessante dessa dissociação entre rima e frase que, até por isso, podem ser vistas como complementares é o da seção A de Vera Cruz, na qual não há rima poética, mas toda a seção é constituída por uma única frase com diferentes derivações ( $a, a^{\prime}$ e $a$ ”). Neste ponto a música parece estruturar o texto.

Do ponto de vista do conteúdo, verifica-se uma mudança na temática das letras, principalmente em contraste com o período da Bossa nova. É apenas nas canções de Baden e Vinícius que o amor ainda figura como tema principal; entretanto, mesmo nelas, não se vê 
aquela perspectiva do "amor, o sorriso e a flor”, mas a das mandingas de amor dos trabalhos para os orixás (Canto de Ossanha) característicos da Umbanda e do Candomblé. Já em Edu Lobo a temática se volta para a simplicidade do povo brasileiro e, especificamente, o sofrimento do povo nordestino com a seca e, por conseqüência sua migração para o Sul e sua religiosidade. Ainda que em todas as canções de Edu Lobo o eu lírico se coloque em primeira pessoa e se trate de letristas diferentes (Vinícius de Moraes e Oduvaldo Viana), tem-se a impressão de que seja nas canções de Milton Nascimento que exista uma visão realmente a partir do povo, ou seja, do cidadão mais simples.

A questão do trabalho mal remunerado pela baixa educação em Canção do Sal e a questão da reforma agrária em Morro Velho estão subjacentes, dentro de uma visão lírica e realista dessas condições, incluindo a relação entre amigos que, com o passar dos anos, tornase uma relação empregador-empregado. Como nestes dois casos (Canção do Sal e Morro Velho) as letras são do próprio Milton, não se pode deixar de imaginar que se trata, ao mesmo tempo, da questão social do negro no Brasil, ainda mais quando elas se contextualizam na segunda metade da década de 1960, período, de extrema efervescência cultural e de contestação, como apontado na introdução. E esse lirismo contemplativo que acompanha tais questões, como a do "menino que cata conchas do mar” ou do "peixe bom que se dá no riacho de águas tão verdinhas”, é o que torna suas canções mais poderosas do que a visão puramente engajada de um Geraldo Vandré.

Por último, embora as canções e suas seções pudessem ser classificadas em protótipos formais preexistentes (período, sentença, seção média, contrastante, etc.) a forma de cada arranjo diferiu completamente um do outro, havendo contração de seções na recapitulação (Chegança) e transposição de seções para tonalidades distintas como em Canção do Sal e Canto de Ossanha. 


\section{Conclusão}

\subsection{Cotejamento dos Dados}

A partir dos dados coletados nesta pesquisa, podem-se definir alguns procedimentos que, por assim dizer, seriam "modalizadores”, ou seja, que efetivamente fazem uma melodia ser modal. O principal deles aqui seria o do traço cadencial apontado nos finais das frases aqui analisadas. São eles que, em última análise, apontam para uma centralidade diatônica (pura ou híbrida) que, nesse caso, não pode conter a sensível como tal ${ }^{130}$. É claro que tessituras e certos contornos melódicos também ajudaram a definir tais centralidades.

A partir das tabelas apresentadas na seção intitulada Considerações Parciais, do capítulo Busca dos Fundamentos Étnico Musicais do Repertório Modal da Música Popular Estudada, pode-se reduzir o número de traços cadenciais através de suas repetições e observar suas reincidências nos capítulos posteriores e, então, observar os processos de harmonização adotados pelos compositores estudados. Por exemplo, na Tabela 3.2, referente ao gênero pentatônico, encontra-se o final $7+2-1$. Sua inversão $(2-7+1)$ será classificada como final $a$, pois se repetirá em outras ocasiões. Assim, será demonstrado abaixo os principais traços desse gênero e seu aproveitamento, adaptações e harmonizações no repertório popular.

\subsubsection{Aproveitamento do Gênero Pentatônico}

Na tabela a seguir, a primeira coluna representa a denominação da cadência, a segunda traz o traço cadencial propriamente dito, a terceira demonstra a canção e o trecho no qual ela foi apresentada, e a última coluna apresenta a respectiva harmonização. Antes de adentrar a tabela, a figura que segue demonstra no pentagrama as notas e harmonização da primeira linha. Os sinais + e - indicam os saltos ascendentes e descendentes, respectivamente.

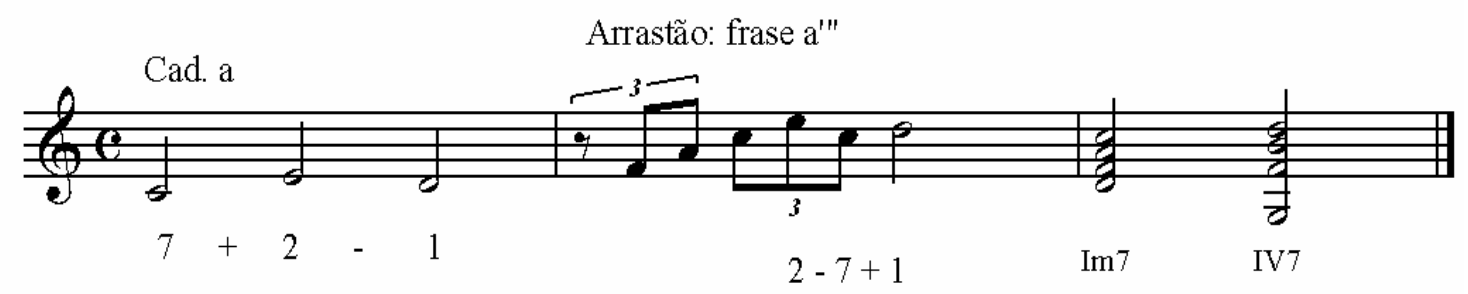

Fig. 6.1 Tabela no pentagrama

\footnotetext{
${ }^{130}$ Fica claro que nem sempre a sétima nota do conjunto diatônico exerce função de sensível, como no caso desta mesma nota no $3^{\circ}$ modo (frígio).
} 
Harmonização:

\begin{tabular}{|l|l|l|l|}
\hline Cadência $a$ & $2-7+1$ & adaptado ao $2^{\circ}$ modo em Arrastão (parte A): & Im7 - IV7 \\
\hline Cad. $a$ ' & $2-7+1$ & adaptado ao $6^{\circ}$ modo em Borandá (parte A): & VII7 - Im7. \\
\hline Cad. $a$ ": & $7+1$ & adaptada ao $5^{\circ}$ modo em Baião (ponte): & I7 \\
\hline Cad. $b$ & $5+7+1$ & adaptada em trecho de Berimbau (parte A): & Im7 -Vm7. \\
\hline Cad. $b$ & & $\begin{array}{l}\text { adaptado ao } 2^{\circ} \text { ou } 6^{\circ} \text { modo em Canção do Sal } \\
\text { (B) }\end{array}$ & II7-IIb7M \\
\hline Cad. $c:$ & $3-7+1$ & $\begin{array}{l}\text { adaptado em } c^{\prime} \text { (3-1-7+1) em Consolação (parte } \\
\text { B): }\end{array}$ & V7-IIb7M \\
\hline Semicad. $d$ & $5-7$ & em Consolação (trecho de A): & Im7 - Vm7 \\
\hline Semicad. $e$ & $1-7$ & adaptado ao $5^{\circ}$ modo em Morro Velho (frase $c$ ): & I7M - Im6 \\
\hline Semicad. $e$ & & adaptada ao 6 $6^{\circ}$ modo em Vera Cruz (seção A): & Vm7 - Im7 \\
\hline
\end{tabular}

Tab.6.1 Cotejamento a partir do gênero pentatônico.

A tabela acima demonstra claramente os processos de harmonizações relacionadas às respectivas cadências melódicas. Entretanto, não faz diferenciações entre o caráter vamp, o do turnaround e o cadencial apresentado nas Considerações Parciais do capítulo anterior, ou sobre uso de um único acorde em Baião. Mesmo assim, vê-se notadamente a transposição do traço melódico 7+1 na cadência $a^{\prime}$ na harmonização VII7 - $\operatorname{Im} 7$ no $6^{\circ}$ modo em Borandá. Esta mesma transposição se dá na famosa e controversa canção de Geraldo Vandré, Pra não Dizer que Não Falei das Flores, que está baseada no $6^{\circ}$ modo diatônico puro somente com os graus Im - VII.

Há também as já demonstradas relações entre Vm7 - Im7, que evitam a sensível melódica, no primeiro aproveitamento da cadência $b$ em Berimbau, no segundo aproveitamento da semicadência $e$ em Vera Cruz e no aproveitamento da semicadência $d$ em Consolação. Por último, há que se ressaltar as harmonizações tonais das cadências melódicas modais no segundo aproveitamento de $b$ em Canção do Sal e no aproveitamento de $c$ em Consolação nas relações II7-IIb7M e V7-IIb7M. Na primeira há, na verdade, um uso indireto do tonalismo, já que ele não se dá em relação à tônica (I) na música, mas em relação ao próprio acorde napolitano (IIb). Ou seja, o II7 exerce aqui a função de Vger. do IIb e este termina por realizar a versão plagal da cadência napolitana ${ }^{131}$ (IIb-I). Já a segunda relação há o uso direto da relação D-T e aponta para uma cadência de engano, que também envolve o acorde napolitano. Mesmo a relação harmônica I7M - Im6, embora não contenha relações de 
D-T, não pode ser considerada característica de um modalismo, mas, sim, de uma relação híbrida, mesmo porque essa relação já é, de certa forma, antológica na música popular, como em Brasileirinho, de Waldir Azevedo, Triste e Vivo Sonhando, de Tom Jobim.

Portanto, no aproveitamento do gênero pentatônico, a cadência harmônica - também desenvolvida na forma de vamp - que mais se utilizou foi a $\operatorname{Im} 7$ - Vm7, que também pode ser invertida em Vm7 - Im7. Este procedimento torna-se, então, paradigmático pelo uso dessas mesmas características, por exemplo, no afro-samba de Egberto Gismonti, em homenagem a Baden, intitulado Salvador ${ }^{132}$, composto nos anos 1960, em em outros diversos, como será demonstrado.

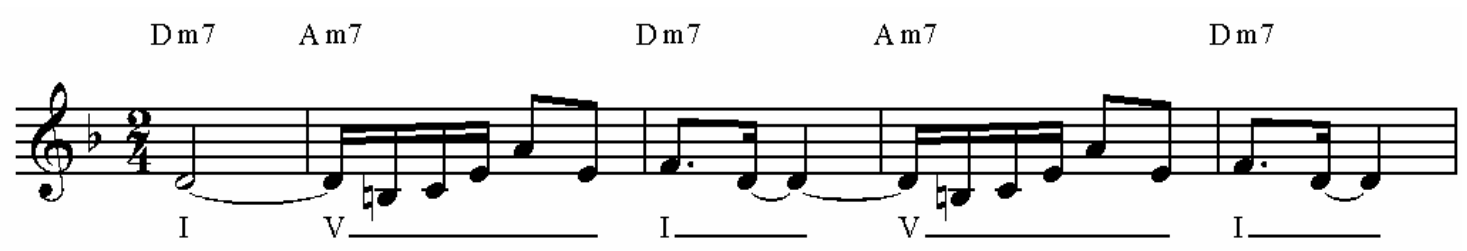

Fig. 6.2 Salvador - trecho

Também os primeiros compassos de Coisa $N^{o} 1$, de Moacir Santos ${ }^{133}$ estão embasados na referida seqüência, ainda que, depois, venha a cadenciar tonalmente.

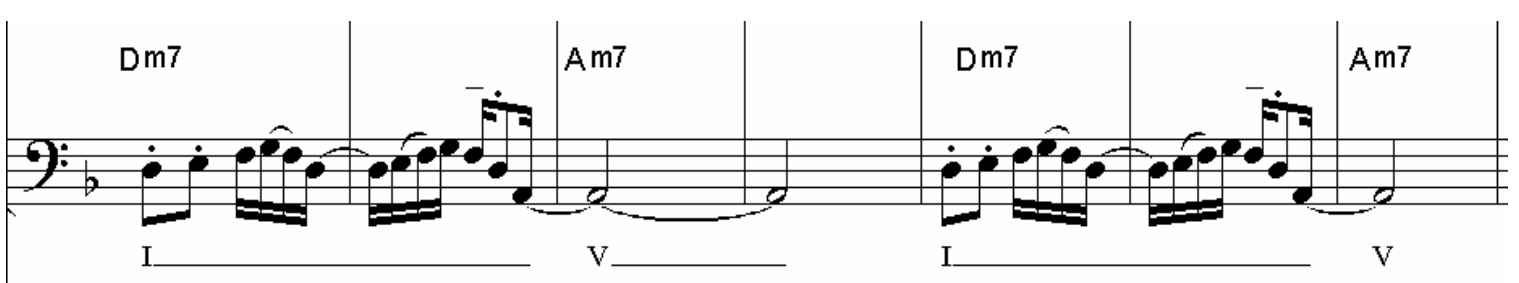

Fig. 6.3 Coisa $N^{o} 1-$ trecho

O refrão de Zambi (Edu Lobo e Vinícius de Moras) apresenta as mesmas características: harmonização de melodia pentatônica com o vamp Im7-Vm7:

${ }^{132}$ GISMONTI, 1990, p.15-18.

133 SANTOS, 2005. p. 34-41. 


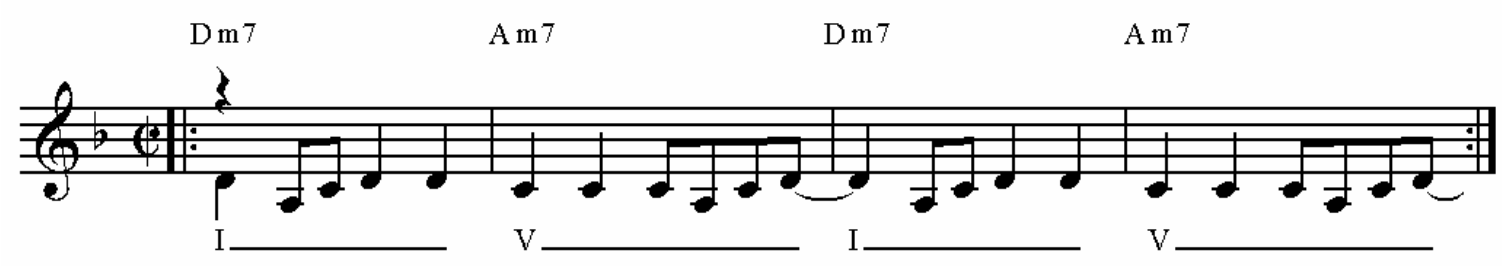

Fig.6.4 Zambi - Refrão

\subsubsection{Aproveitamento do Gênero Diatônico Puro: $5^{\circ}$ Modo}

Na Tabela 6.3 do referido capítulo encontram-se os finais relacionados ao $5^{\circ}$ modo (mixolídio), que apresenta os seguintes desdobramentos:

\begin{tabular}{|c|c|c|c|}
\hline Cad. $a$ : & $3-2-1$ & em Juazeiro (seção A): & V7 - I \\
\hline Cad. $a$ ': & $2-1$ & adaptada em Baião: & VIIb7 - V7 - I7 \\
\hline Cad. $a$ : & “ & no refrão II de O Canto da Ema: & I. \\
\hline Cad. $b$ : & $6+1$ & na coda de Juazeiro: & IV - I. \\
\hline Cad. $b$ : & "“ & na frase $a$ de $O$ Canto da Ema: & I. \\
\hline Cad. $b$ : & “ “ & no refrão de Canto de Ossanha: & V7 - Im7. \\
\hline Semicad. $c$ : & 3-1 & no refrão de 17 na Corrente: & V7 - I7. \\
\hline Semicad. $c$ : & ““ “ & no refrão I de O Canto da Ema: & V7 - I. \\
\hline Semicad. $c$ : & “ “ & frase $b$ de Chegança: & V7 - I. \\
\hline Semicad. $d$ : & $6-5$ & frase $a$ da Intro. de Juazeiro: & V7 - I. \\
\hline Cad. $e$ : & $7-6-5$ & frase $a$ de Baião (A): & I7 \\
\hline Cad. $e$ : & “" “ & aproveitamento misto $\left(2^{\circ}\right.$ e $\left.6^{\circ}\right)$ Morro Velho (B): & $\mathrm{IIb}-\mathrm{IVm} 7 .^{134}$ \\
\hline Cad. $f$ : & $1-7-5$ & frase $e$ em Baião (ponte): & I7. \\
\hline Cad. $f$ : & “ “ & Aproveit. pentatônico Morro Velho ( $a$ de B): & IIb-Im7 \\
\hline
\end{tabular}

Tab.6.2 Cotejamento a partir do gênero diatônico puro (5º modo).

O traço melódico $b$ pode ser considerado um dos mais importantes e característicos para os processos de modalização, e a já apontada hamonização plagal (IV-I) parece ser aquela que mais se adapta ao traço, principalmente quando cadencial. Entretanto, ele também pôde ser harmonizado tonalmente em Canto de Ossanha, tal como o traço cadencial $a$. Já o traço semicadencial $c$ teve três harmonizações tonais, sendo que, em 17 na Corrente, ela se

\footnotetext{
${ }^{134}$ Neste ponto a frase melódica se resolve, mas a harmonia se movimenta em cadência II-V de retorno à tonalidade da seção A.
} 
resolve no I grau com $7^{\mathrm{a}}$ menor. Muitos apresentaram harmonizações com apenas um acorde que aumenta o teor modal quando é adicionada a extensão da $7^{\mathrm{a}}$ menor, característica do modo aqui estudado (mixolídio). Por fim, é importante ressaltar novamente o aparecimento do acorde napolitano (IIb) na cad. $e$.

\subsubsection{Aproveitamento do Gênero Diatônico Puro: $6^{\circ}$ Modo}

Na Tabela 6.4 do respectivo capítulo encontram-se os finais relacionados ao $6^{\circ}$ modo (eólio), que apresenta os seguintes desdobramentos:

\begin{tabular}{|l|c|l|l|}
\hline Cad. $a:$ & $3-1$ & adaptada ao $2^{\circ}$ modo na cad. final de Vem, Morena: & V7-Im \\
\hline Cad. $a:$ & $3-1$ & adap. ao gênero pentatônico em Consolação (c de A): & Vm7-Im7 \\
\hline Cad. $b:$ & $3-2-1$ & no refrão de Berimbau (semifrase $a$ ”): & V7-IIb \\
\hline Semicad.c: & $4+5$ & adap. ao gênero pentatônico em Canto de Ossanha: & IIb7M-Im7 \\
\hline Semicad.d: & $4-3$ & na frase $b$ de Morro Velho (B): & IIb7M-Im7 \\
\hline
\end{tabular}

Tab.6.3. Cotejamento a partir do gênero diatônico puro (6º modo).

A cadência $a$ também ocorreu no $5^{\circ}$ modo (semicad. $c$ ), sendo que aqui está adaptada ao modo menor. A harmonização aqui encontrada é adaptada ao gênero pentatônico, que utiliza o referido vamp Vm7-Im7. Já a ampliação em 3-2-1 na cadência $b$, embora harmonizada tonalmente, cai em forma de cadência de engano no acorde napolitano com $7^{\text {a }}$ maior: IIb. Este procedimento também é utilizado nas semicadências $c$ e $d$, em resolução plagal (II-I). Por último, as cadências propriamente do $6^{\circ}$ modo foram extraídas de procedimentos melódicos pentatônicos e sua transposição para o nível harmônico (cadência VII - Im).

\subsubsection{Aproveitamento do Gênero Diatônico Puro: $4^{\circ}$ Modo}

Na Tabela 6.5 encontram-se os finais relacionados ao $4^{\circ}$ modo (lídio), que apresenta os seguintes desdobramentos:

\begin{tabular}{|l|l|l|l|}
\hline Cad. $a:$ & $4-2-1$ & na parte A, frase $a$ e $c$ de Chegança: & II7-I6. \\
\hline Cad. $a:$ & $4-2-1$ & na seção A de Canção do Sal: & II7-V7-I6. \\
\hline Cad. $b:$ & $1+2-1$ & adap. ao 5 modo em Baião ( $e^{\text {’ na ponte): }}$ & I7 \\
\hline
\end{tabular}

Tab.6.4. Cotejamento a partir do gênero diatônico puro (4º modo). 
Apesar do pouco aproveitamento do $4^{\circ}$ modo encontrado neste trabalho, ele não deixa de ser significativo, na medida em que esta cadência melódica $a$ (4-2-1) figura em importantes canções na década estudada, como as citadas na tabela, bem como outras que foram mencionadas no decorrer da pesquisa, como Upa, Neguinho, (Edu Lobo e Gianfrancesco Guarnieri), cuja harmonização é a mesma de Chegança.

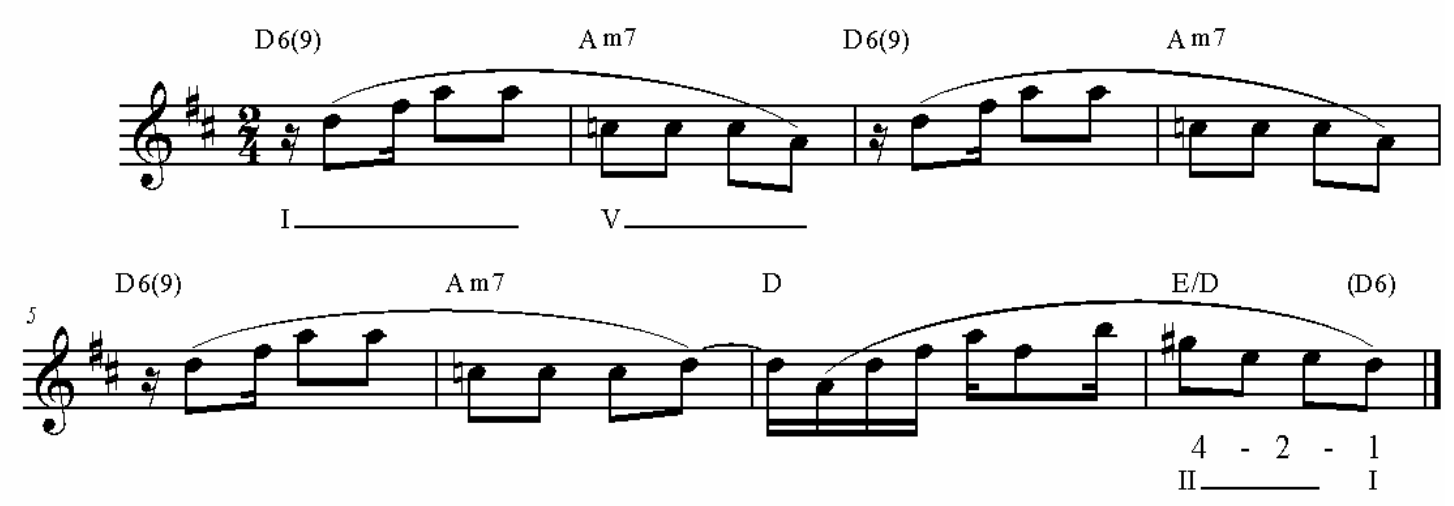

Fig.6.5 Upa, Neguinho - Cadência ${ }^{135}$

Além disso, pode-se notar que duas harmonizações foram encontradas: a primeira, que transpõe para o nível harmônico $a$ o movimento 2-1, sendo os acordes derivados do mesmo modo II7-I6, pois, do contrário, o primeiro acorde seria menor com $7^{\mathrm{a}}$ menor. Ou seja, tem-se aqui uma cadência plagal no $4^{\circ}$ modo! A segunda harmonização da cad. a claramente a tonaliza pelo uso do acorde dominante com a referida função. O II7 passa então a ter uma dupla funcionalidade: uma cadencial, o II de uma seqüência II-V e, isoladamente, V7 do V, dominante da dominante.

\subsubsection{Aproveitamento do Gênero Diatônico Puro: $2^{\circ}$ Modo}

Na Tabela 6.6 encontram-se os finais relacionados ao $2^{\circ}$ modo (dórico), aqui apresentando os seguintes desdobramentos:

\begin{tabular}{|c|c|c|c|}
\hline Cad. $a$ : & 3-1 & frase $a^{\prime}$ de Vem, Morena: & IV7-Im \\
\hline Cad. $a$ : & 3-1 & frase $c$ de Vem, Morena: & V7-Im \\
\hline Semicad.b: & $6+1$ & adaptado ao $2^{\circ}$ modo em $b$ e $b$ " de Vem, Morena: & $\operatorname{Im}$ \\
\hline
\end{tabular}

Tab.6.5 Cotejamento a partir do gênero diatônico puro ( $2^{\circ}$ modo).

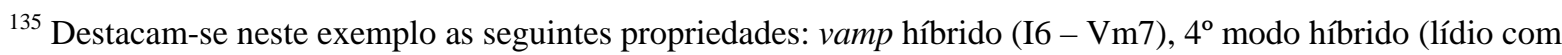
$7^{\mathrm{a}}$ menor). A cadência 4-2-1 encontra-se associada às palavras mas liberdade só posso esperar, enquanto em Canção do Sal, ao trecho e vida de gente levar. Ou seja, há certa expressão de lamento e almejo por melhores condições.
} 
Apesar de se terem encontrado poucos exemplos do $2^{\circ}$ modo no âmbito étnicomusical, pode-se notar o significativo aproveitamento no âmbito popular. A cadência $a$ também ocorreu no $5^{\circ}$ modo (semicad. $c$ ) e no $6^{\circ}$ modo (cad. $a$ ). Aqui, duas harmonizações foram encontradas: aquela do vamp IV7 - Im que prioriza o $2^{\circ}$ modo harmonicamente, que também ocorreu, de maneira invertida (Im - IV), na harmonização do toque em Berimbau. Vale lembrar aqui seu uso em introduções e codas das canções de Jobim, como Wave e Desafinado, e o uso da mesma seqüência em Reza, de Edu Lobo, também lançada no primeiro disco, associado aos traços cadenciais $6+1$ e $7+1$ do $2^{\circ}$ modo. $^{136}$
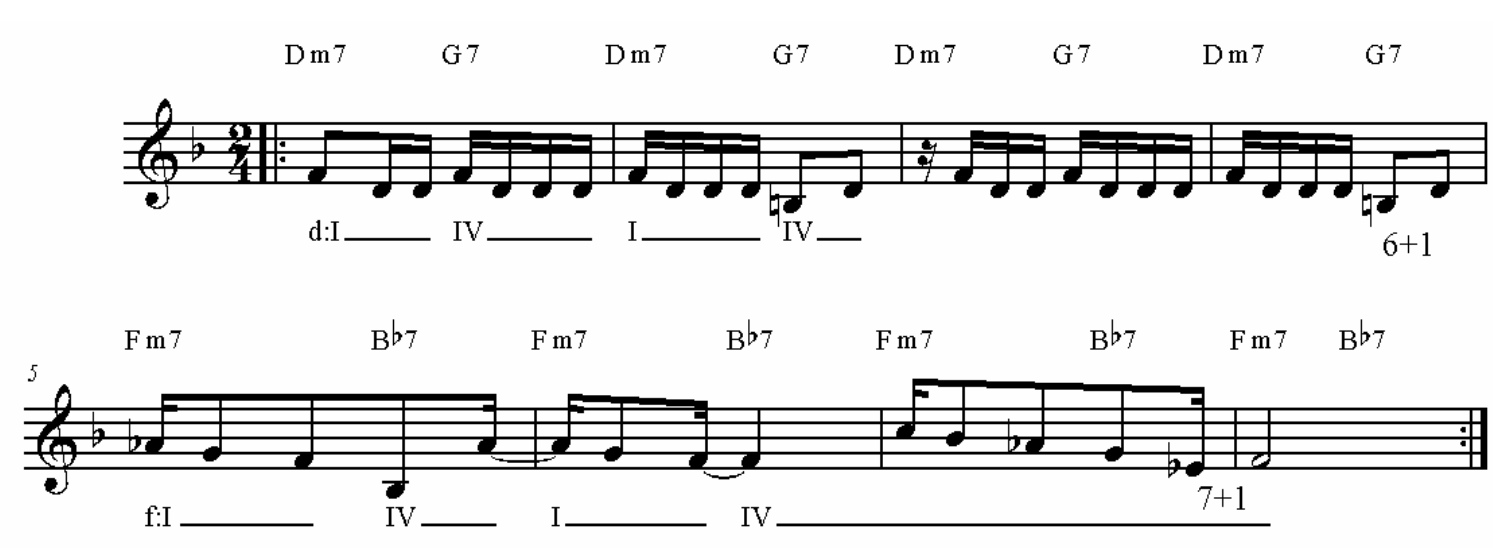

Fig.6.4 Reza - Refrão

A outra harmonização para a cadência $a$ é claramente tonal em Vem, Morena. A semicadência $c$ 6+1 está, de antemão, adaptada ao $2^{\circ}$ modo, já que esta também foi encontrada no $5^{\circ}$ modo.

Cabe lembrar aqui que buscou-se encontrar os traços melódicos cadenciais dentro do corpus étnico escolhido. Entretanto, tais traços os transcendem na medida em que poderiam ser encontrados outros exemplos. Tal fato aponta para uma concepção de que as tradições orais partilham elementos semelhantes dentro de uma prática comum, coletiva e não personalizada e, de certa forma, “atemporal”. O que de certa forma os compositores populares escolhidos farão é exatamente a personificação de tais procedimentos em suas composições. Ainda que certas fórmulas, principalmente harmônicas, possam ser compartilhadas, elas já não o são por uma coletividade, mas por uma categoria de compositores profissionais.

\footnotetext{
${ }^{136}$ Neste caso ocorre uma transposição do vamp de ré para fá.
} 


\subsection{Uso do IIb: Despontar do Frígio}

Muito embora nenhum exemplo étnico fosse encontrado no $3^{\circ}$ modo diatônico puro (frígio), vários procedimentos apontaram para o uso do acorde napolitano, a saber: o da cadência de engano nesse acorde em Consolação e Berimbau, ou as versões plagais da cadência napolitana IIb7m-Im em Morro Velho e Canto de Ossanha; e II7-IIb7M em Canção do Sal. Parece que, na própria busca intuitiva pelo exótico, os compositores extrapolaram o escopo étnico e fizeram uso desse acorde e cadência que são tão próprios ao $3^{\circ}$ modo. Em outras importantes canções da época, como Ponteio, de Edu Lobo e Capinan, (LOBO, 1994, p.198-200), há o uso da vamp IIb7M-Im7M que, embora híbrido, pois o segundo acorde está com $7^{\mathrm{a}}$ maior - não correspondendo exatamente ao acorde do III grau diatônico que teria $7^{\mathrm{a}}$ menor -, prioriza uma tonalidade menor sem o artifício da dominante e através do movimento descendente de $2^{\mathrm{a}}$ menor no baixo. O uso desse vamp com o segundo acorde com $7^{\mathrm{a}}$ menor se dá na seção B em Zambi, de Edu Lobo e Vinícius de Moraes (LOBO, 1994, p.246-249).

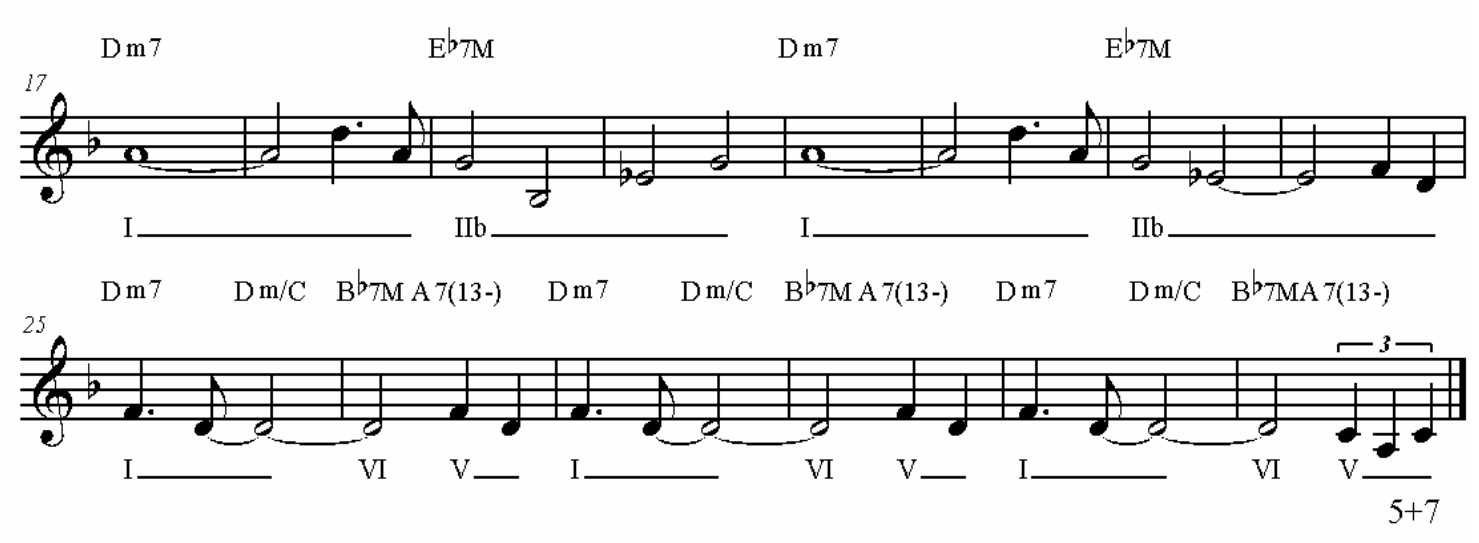

Fig.6.5 Zambi - seção B

As antológicas canções Clube da Esquina (Milton Nascimento, Lô Borges e Márcio Borges) $)^{137}$ e Clube da Esquina $N^{o}$ 2, (Idem) ${ }^{138}$ ampliam o vamp IIb7M-Im7 em um turnaround modal: IIb7M-Im7-VIIbm7-Im7. Esta priorização do $3^{\circ}$ modo se dá através da transposição da bordadura melódica 4-3-2+3 para o nível harmônico.

\footnotetext{
${ }^{137}$ NASCIMENTO, Milton. Milton. Rio de Janeiro: EMI-Odeon, 1970. Faixa 4 (CD).

${ }^{138}$ NASCIMENTO, Milton e Borges, Lô. Clube da Esquina. Rio de Janeiro: EMI-Odeon, 1972. Faixa 11 (CD).
} 


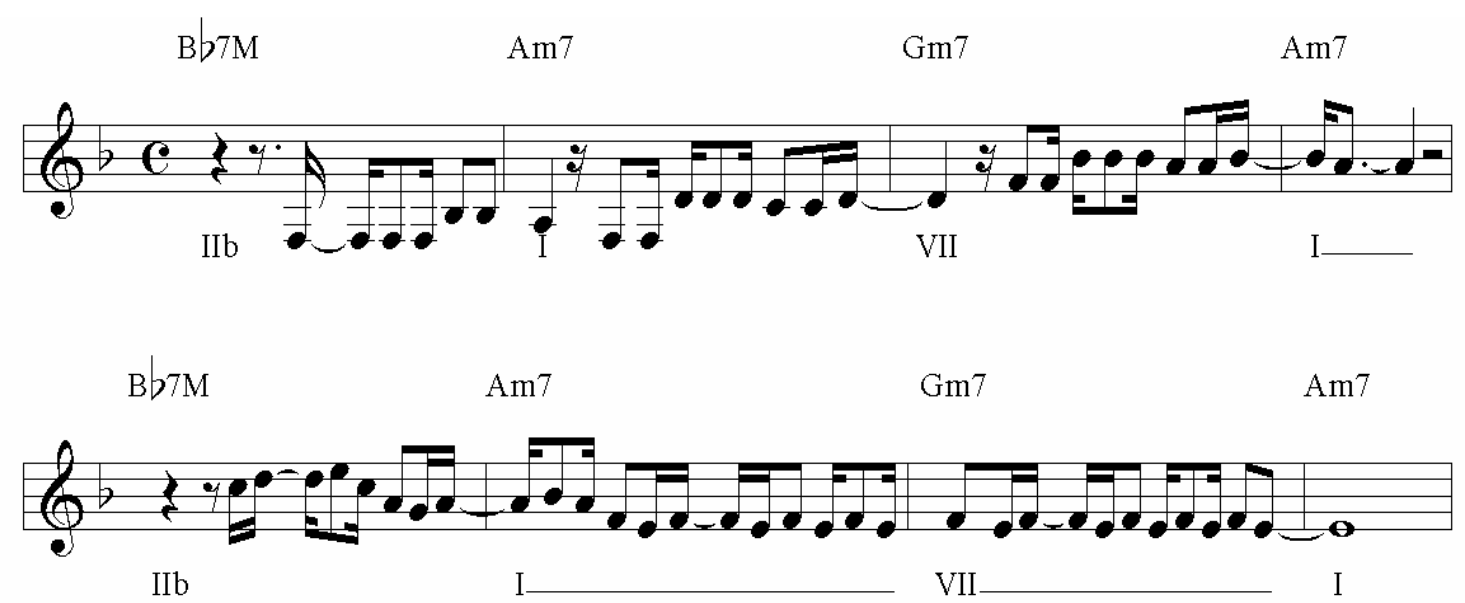

Fig.6.6 Clube da Esquina $N^{\circ} 2$ - trecho

No caso da cadência frígia também se verifica a mesma mudança para a tônica ocorrida na música popular de fenômenos que ocorrem, no âmbito da música clássica, primeiro na dominante. Por exemplo, o caso dos acordes de $6^{\text {a }}$ aumentada que se resolviam na dominante nos exemplos clássicos e passam a ser chamados de subV no jazz, demonstrados no capítulo Ferramentas Analíticas da já referida dissertação de mestrado (TINÉ, 2001). A cadência frigia realiza o movimento IV6b-V (PISTON, 184) em semicadência ou cadência interrogativa e, aqui, trata-se de uma resolução no I grau. Mesmo assim, tal como no caso da cadência plagal, Shoenberg também a considera um “meio de expressão estilístico” que não possui “importância estrutural” (SHOENBERG, 2004, p.32).

\subsection{Procedimentos Harmônicos Ligados ao Modalismo}

Quando se cotejam os resultados obtidos através das análises realizadas neste trabalho com aqueles mencionados em relação ao jazz no capítulo Revisão dos Parâmetros Analíticos, podem-se destacar, basicamente, quatro procedimentos harmônicos modais:

1. O da Cadência Modal, quando a totalidade do tema ou melodia não está harmonizada de maneira a pertencer exclusivamente a este ou aquele modo, mas que, no momento cadencial, ou seja, nas frases que encerram seções, períodos, sentenças, etc, a sucessão harmônica se dá de maneira a evitar a relação D-T, como no caso da analisada Vera Cruz em sua seção A. A famosa canção Odara, de Caetano Veloso ${ }^{139}$, lançada na década de 1970, também apresenta características

\footnotetext{
${ }^{139}$ CHEDIAK, Almir (org.). Songbook Caetano Veloso. Rio de Janeiro: Ed. Lumiar, $1^{\text {o }}$ Vol., S/D. P. 97.
} 
semelhantes: uma cadência VIIb7-Im7 no 6º modo (eólio) diatônico puro depois de, nas frases de contraste, passar pela cadência secundária II-V do IV;

2. O da Cadência Tonal em Melodias Modais, quando a melodia está claramente dentro de um modo e a harmonização; nesse ponto nevrálgico que é o da cadência, realiza uma “tonalização” através da relação D-T ou com cadências de engano. Este é, praticamente, o procedimento adotado pelos compositores-intérpretes Luiz Gonzaga e Jackson do Pandeiro, abordados no capítulo correspondente. Entretanto, tal procedimento também foi adotado por Milton Nascimento na seção A de Canção do Sal, por Edu Lobo em Borandá e até mesmo por Baden que, no refrão de Berimbau, utiliza a cadência V7-IIb7M para uma melodia pertencente ao $6^{\circ}$ modo (eólio);

3. O do vamp e turnaround. Nas composições de Jobim, o modal vamp caracterizava uma introdução ou coda. Aqui ele se torna o modus operandi da canção de tal modo que um único vamp é, por muitas vezes, a harmonia de toda uma seção. Aqui o turnaround, que pode ser entendido simplesmente como cadência, é visto como uma pequena expansão do vamp que, no lugar de dois, possui três ou quatro acordes. Os vamps caracterizaram as seções A de Consolação e Berimbau e sua extensão, o turnaround modal, figurou na seção B de Canção do Sal e A de Canto de Ossanha;

4. Por fim, um procedimento caracteristicamente jazzístico é o da Saturação dos Acordes, através do uso máximo de suas extensões, fato que culmina na verticalização de um modo. Este procedimento foi demonstrado no desenvolvimento dos temas de Miles Davis So What e Milestones, caminhando para Maiden Voyage, de Herbie Hancock, e casos híbridos como Time Remembered, de Bill Evans, demonstrados no Capítulo 2.

Este último item também pode ser visto como uma ampliação do fato ocorrente em alguns baiões e cocos abordados no capítulo referente a Jackson do Pandeiro e Luiz Gonzaga, nos quais um refrão ou uma ponte baseia-se num único acorde dominante, como em Canto da Ema e Baião, que terminam por caracterizar o $5^{\circ}$ modo. 
Com efeito semelhante atua também a técnica de repetição e ênfase em uma tônica pedal a partir de um baixo fundamental na música do Norte da Índia. Segundo Harold Powers, esta técnica introduzida pelos povos islâmicos a partir do século XIII - a fundamental é reinterada através da tambura - "adiciona uma dimensão extra e quase harmônica [grifo nosso] para a modalismo indiano”.

The drone-tonic is the one, and only, sound common to all ragas of the system. It permeates the whole atmosphere of a performance, with the twanging of the four-stringed tambura, the incessant reiteration of the tonic from the tuned drum, the frequent return to or sustaining of the tonic in solo. The drone-tonic adds, as it were, an extra, quasi-harmonic dimension to Indian modality [...] (POWERS, 1958, p.456)

\subsection{Relação entre Conteúdo e Material}

Na relação entre assunto abordado pelas canções da década de 1960 analisadas neste trabalho e o material melódico de base, nota-se uma relação clara entre pentatonismo e temática afro-brasileira. Como referido no capítulo etnográfico, as melodias que se baseavam na escala pentatônica pertenciam às manifestações deste cunho, como o Candomblé e a Capoeira. Parece óbvio que, quando os autores quiseram retratar essa ambiente, terminaram por lançar o uso daquele material como nas seções A de Consolação e Canto de Ossanha. Pode-se ainda citar outras canções que fazem essa mesma relação entre pentatonismo e temática afro, como o Canto de Xangô, que também pertence ao ciclo do afro-sambas de Baden e Vinicius, e as já mencionadas Zambi, de Edu Lobo, e Coisa $N^{o}$ 5, de Moacir Santos, também intitulada de Nana, em menção a mais um orixá de origem africana. 


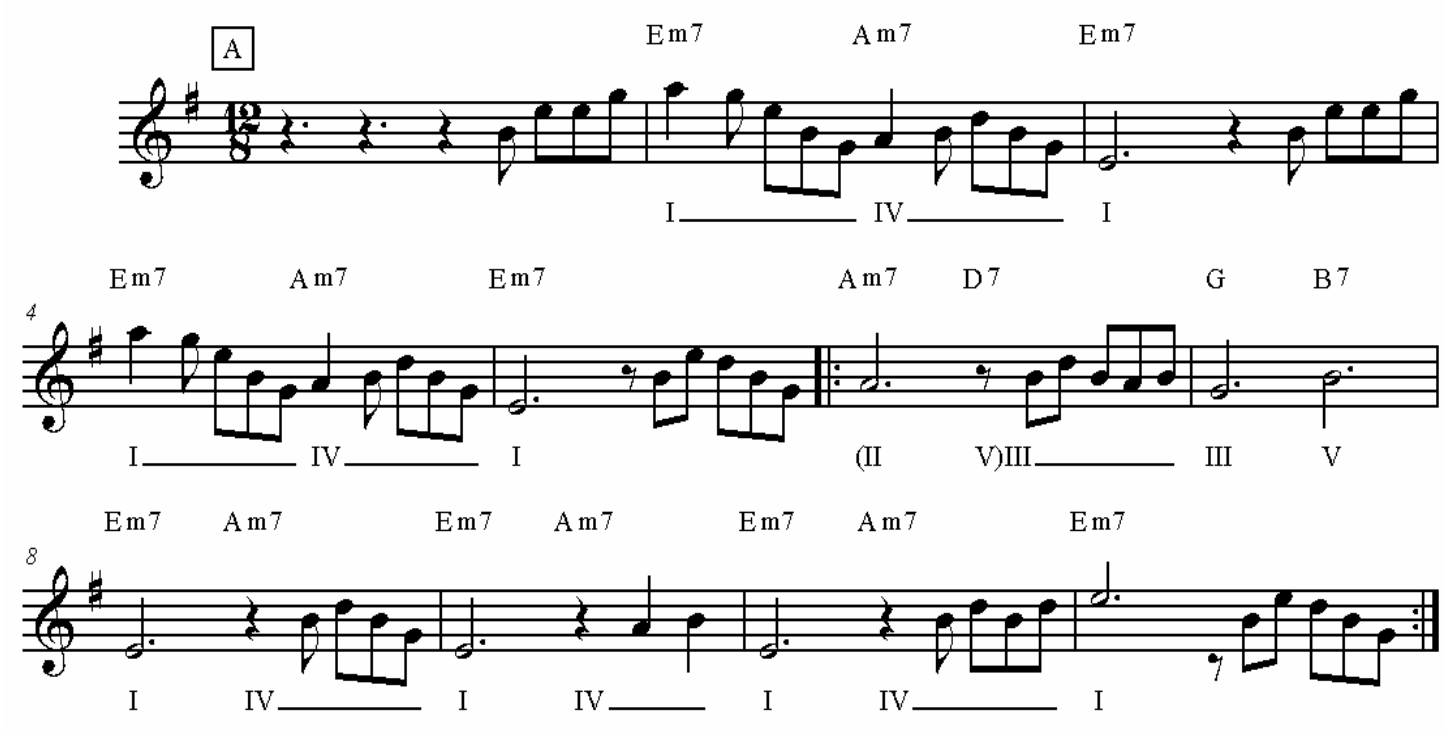

Fig.6.7 Canto de Xangô - seção A

Já em relação aos $5^{\circ}, 4^{\circ}$ e $2^{\circ}$ modos do gênero diatônico puro, apresenta um claro aproveitamento dentro de uma temática nordestina. Borandá e Chegança tratam claramente da problemática da seca. A primeira canção traz uma visão crítica da religiosidade popular que, paradoxalmente, utiliza os elementos melódicos derivados daquela região, e a segunda tratando da questão da migração, também ocasionada pela seca. A questão do analfabetismo e da baixa escolaridade das classes menos abastadas da população brasileira foi associada ao $5^{\circ}$ modo em Canção do Sal.

\subsection{Construção da Identidade através da Alteridade}

Como demonstrado, desde os exemplos étnicos, filtrados por Jackson do Pandeiro e Luiz Gonzaga, até os compositores da década de 1960, sempre houve uma predominância de abordagens tonais sobre as modais do ponto de vista quantitativo. Quer dizer, dos exemplos selecionados para formar o corpus deste trabalho foram retirados de diferentes contextos os quais, em sua maioria quantitativa, é formada por manifestações tonais, excetuando-se, talvez, as manifestações afro-brasileiras do Candomblé e a Cantoria Nordestina. A grande maioria dos exemplos de Coco, Catimbó, Capoeira tratava-se de melodias tonais que foram excluídas na medida em que o foco deste trabalho se deu na direção oposta. A própria análise das melodias de obras significativas do musicólogo e escritor Mário de Andrade, apontadas no decorrer das análises, indicam o mesmo dado. 
Em relação ao repertório de Luiz Gonzaga e Jackson do Pandeiro ocorre exatamente a mesma coisa e, além disso, certos exemplos melódicos modais foram harmonizados tonalmente dentro de uma perspectiva de estilização dos gêneros étnicos. Entretanto, pode-se dizer que as músicas mais significativas e representativas deste segmento e que causaram impacto nos meios de comunicação da época eram as notadamente modais, como o caso do Baião e Canto da Ema. É exatamente essa freqüência auditiva que levou os compositores da década de 1960 a construir seus repertórios de embasamento popular dentro de características modais porque são qualitativamente significativas; qualitativamente porque, além do aspecto rítmico, elas se determinam pela diferença, na medida em que esse fenômeno pertence quase exclusivamente a essa região do Brasil ${ }^{140}$.

Na mesma direção atua o repertório dos compositores aqui estudados: Baden, Edu Lobo e Milton. Seus repertórios não são exclusivamente modais, mas, da forma demonstrada, o modalismo se associou a uma questão de identidade e afirmação de brasilidade associado aos aspectos rítmicos e aos assuntos abordados nas letras. Além disso, em uma mesma canção foram utilizados procedimentos modais e tonais, sendo o último utilizado principalmente nos refrões dos afro-sambas. Essa identidade, como se afirmou, foi construída através da alteridade, quer dizer, através do diferente e do diferencial que a riqueza étnica do Nordeste, afro no caso baiano, manifesta.

Poder-se-ia objetar aqui o fato de que, se se colocasse em uma lista a data de todas as gravações aqui estudadas, alguns exemplos étnicos foram colhidos depois de ocorrido o fato histórico da década de 1960. Entretanto, permanece a idéia de que, ainda que dinâmico e sujeito às aculturações advindas da cultura de massa, as culturais orais mantêm até certo ponto intactas as nuanças aqui demonstradas, tão válidas para o fundamentar esses compositores. Ou, no mínimo, as mudanças ocorridas neste âmbito se dão de maneira mais lenta.

Nesse contexto, o musicólogo J.J. Nattiez, ao abordar criticamente as concepções do especialista romeno Constantin Brailoiu, tece as seguintes considerações relacionadas com as manifestações étnicas que, em última análise, estão sintonizadas com o descrito conceito da abordagem sincrônica da lingüística.

Em Brailoiu, a análise sistemática, a busca dos universais e, [...], uma certa metafísica da 'criação coletiva', são inseparáveis, estando tudo isso enraizado no empreendimento comparativo. Sob tudo isso, descansa a negação do tempo. [...] O 'primitivo' não se preocupa em inovar [...] ela [a

\footnotetext{
${ }^{140}$ É realmente difícil afirmar que o modalismo esteja presente exclusivamente no Nordeste brasileiro, como manifestações étnicas. Mas pelo menos o tipo de modalismo aqui descrito, baseados principalmente no $5^{\circ}$ modo, é exclusivo daquela região.
} 
criação popular] não é uma obra acabada, mas algo que se cria e recria perpetuamente. Isso significa que todas as performances individuais de um padrão melódico são igualmente verdadeiras e possuem o mesmo peso na balança do juízo. Significa também, que o "instinto de variação" não é uma simples paixão pla variação, mas uma conseqüência necessária da ausência de um modelo irrecusável. [...] As obras musicais viajam através do tempo sujeitas a duas tendências: a perpetuação pela reprodução e, no cerne da reprodução, a variação. (NATTIEZ, 2006, p. 76 - 77)

\subsection{Relação Letra e Música}

Aparentemente a relação mais clara entre texto e música estudada neste trabalho foi a da quadra poética com as estruturas binárias do período ou sentença e das sextilhas e tercetos com a estrutura ternária, como em Vem, Morena (Gonzaga e Dantas), na parte C de Arrastão, na introdução e seção A de Vera Cruz. Há que se ter em conta que, de uma maneira geral, dentro das manifestações étnicas não há uma dissociação desses termos, quer dizer, não há a composição destes em separado, eles são criados, ou às vezes improvisados ao mesmo tempo.

O caso da cantoria é significativo, pois, para uma mesma melodia são improvisados diferentes versos que, via de regra, obedecem a uma mesma métrica. Tal fato coincide com as considerações parciais do Capítulo V, de que a métrica é normalmente repetida quando se repete uma frase. Além disso, mesmo a questão da ascendência do canto silábico sobre o melismático se estende aos campos étnico e popular nos exemplos estudados nos capítulos anteriores (2 e 3), excetuando-se, talvez, os cantos em yorubá.

Por outro lado, no caso dos compositores populares estudados, a melodia é normalmente criada primeiro e, posteriormente, acrescida a letra. Nesse caso, normalmente, uma irregularidade fraseológica é correspondida por uma irregularidade métrica. É importante ressaltar o papel que o responsório exerce no sentido de adaptar certas inconstâncias métricas em regularidades fraseológicas, como no verso de repetição extra de Consolação, que faz a quintilha corresponder à estrutura ternária, ou em Chegança na primeira seção que, a rigor, possui cinco versos que são repetidos de diferentes maneiras para fechar duas quadras correspondentes à sentença.

Nesse contexto é relevante a importância do poeta e diplomata Vinícius de Moraes que, dentre as obras selecionadas, foi parceiro na elaboração das letras nas músicas de Baden Powell e Edu Lobo (Arrastão), além de outras aqui citadas, como Zambi e todos os afrosambas. Depois ter trabalhado com Tom Jobim na época da bossa nova, foi capaz de aglutinar em seu torno talentos de uma nova geração. O fato de ser poeta talvez confira uma maestria 
na escolha das palavras. Por outro lado, parceiros de Milton Nascimento, como Marcio Borges (1996), refutam definirem-se como poetas, mas insistem na idéia de que seu artesanato seja outro, o de letristas.

Caberia aqui ainda a sugestão de investigação de como um compositor erudito brasileiro constrói uma canção ou lied já que, nesse caso, o processo é exatamente o oposto: normalmente ele sai da letra para compor a música.

\subsection{Aspectos Rítmicos relacionados ao Modalismo}

Apesar do enfoque e do recorte deste trabalho não lançarem mão do aspecto rítmico no sentido do aproveitamento de texturas e "levadas” - para usar o termo coloquial dos músicos populares - derivadas do repertório étnico e aplicada ao meio popular, este certamente também contribui para a construção de uma identidade musical, seja brasileira no caso do samba, seja nordestina nos casos do baião, frevo e maracatu, por exemplo. Entretanto se, num primeiro momento, estes últimos gêneros caracterizavam o regional através das figuras um tanto caricaturais de Luiz Gonzaga e Jackson do Pandeiro ao olhar sulista, tornaram-se meios de afirmação nacional, e, portanto, de identidade, através dos compositores da década de 1960.

Mas relevante aqui é que tais levadas rítmicas se davam, no âmbito étnico e nos primeiros porta-vozes citados de tais manifestações, de maneira associada ao modalismo, ou seja, junto com textura rítmica do baião existe um modalismo característico, junto com os aspectos rítmicos do Candomblé há um pentatonismo associado, e assim por diante. Neste sentido nota-se, a partir das peças populares analisadas neste trabalho, as seguintes associações: Baião e Coco: $5^{\circ}$ ou $2^{\circ}$ modo; Afro-samba: pentatonismo. Cabe lembrar que, dentro dos exemplos étnicos observados neste trabalho, os Cocos, Catimbós e Capoeiras não apresentaram essa associação tão clara entre gênero e modo, mas a Cantoria e Candomblé, sim. Entretanto, o aproveitamento dos ritmos de origem africana nos afro-sambas não chega ao ponto de utilizar exatamente o toque dos orixás, mas a fórmula de compasso foi mantida: o binário simples de Ossaim se manteve em Canto de Ossanha.

Segundo o pesquisador Marcos Branda Lacerda, "a existência do standard pattern na cultura brasileira é expressão direta da apropriação de padrões musicais da África Ocidental” (Revista Opus, p.213). Ou seja, há aqui um duplo processo de aculturação: da África para o Brasil e do universo étnico brasileiro para o popular. Ainda neste quesito, dois elementos foram retirados, segundo o autor, de sua matriz africana dentro da realidade brasileira: o 
offbeat e o cross rhythm, permanecendo as texturas na construção do standard pattern. Normalmente, esse pattern é chamado de toque pelos músicos brasileiros de tradição oral e é executado por instrumentos agudos, como o agogô ou o gonguê ${ }^{141}$, que corresponde ao gan da terminologia ioruba e fon, embora, sempre segundo o autor, "apenas entre o Ioruba a execução do standard pattern e de outros padrões com função similar não cabe a um instrumento estridente” (Revista Opus, p.219).

Conforme assinalou Mário de Andrade, há na tradição rítmica brasileira uma enorme presença do compasso binário simples. Uma das poucas permanências dos compassos compostos encontram-se nas manifestações afros da Bahia: "No Brasil são conhecidos os toques Alujá (para Xangô), o toque de Ogum e o toque de Kêtu ou Vassá que contêm o standard pattern na parte do agogo” (Ibid., p.212). Nota-se que, apesar de o toque específico de Xangô não ter sido aproveitado no afro-samba de Baden e Vinícius para o mesmo orixá, há a permanência do quaternário composto:

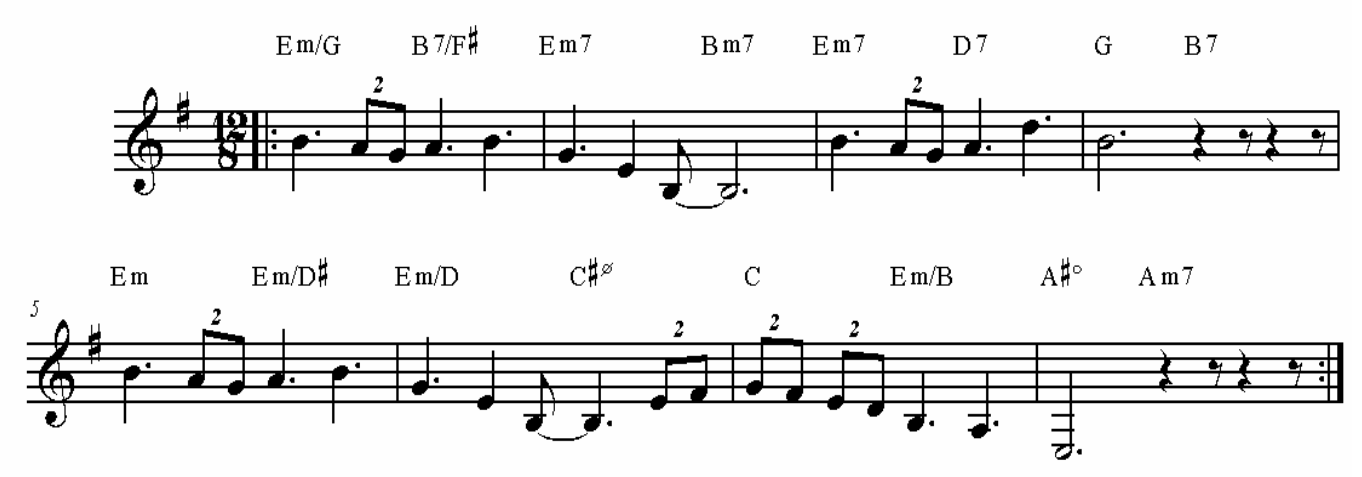

Fig.6.8 Canto de Xangô - Refrão

O mesmo acontece com o exemplo de Yemanjá, aqui escolhido, e a peça de título homônimo que integra os afro-sambas. Entretanto, em relação à capoeira, Baden utilizou literalmente o toque São Bento Pequeno, adaptando-o ao violão.

A partir do final da década de 1960 começa a acontecer uma dissociação entre esses dois aspectos, modo e ritmo característico. Neste trabalho a canção Vera Cruz é um exemplo dessa dissociação. A “levada” ou acompanhamento rítmico na gravação de referência corresponde ao gênero do Baião enquanto o modo é o $6^{\circ}$ do gênero diatônico puro quando o esperado seria o $5^{\circ}$ ou o $2^{\circ}$. Nesse mesmo sentido nota-se, ainda, o tema Bebê, de Hermeto

\footnotetext{
${ }^{141}$ Instrumento de campana única, ao invés de dupla como no caso do agogô, executado nos Maracatus Pernambucanos.
} 
Pascoal $^{142}$, no qual há uma figuração rítmico-melódica de choro tendo como pano de fundo o mesmo baião.

Outro exemplo de tal procedimento acontece em alguns frevos de Edu Lobo, como em No Cordão da Saideira, no qual há um processo de "bossa-novização" do gênero. Sendo o frevo um gênero eminentemente tonal, Edu Lobo transpõe a condução rítmica para o violão e harmoniza a melodia com acordes repletos de extensões. Por conseqüência, a interpretação intimista, sem os instrumentos de sopro que tanto caracterizam o gênero, não deixa de lembrar o processo que João Gilberto fez com o samba alguns anos antes.

\subsection{A Fraseologia e o Modalismo}

Do ponto de vista das estruturas fraseológicas estudadas, tanto no repertório Gonzaga e Jackson quanto no repertório da década de 1960, observou-se um predomínio das estruturas ternárias e das sentenças, ainda que este conceito, como referido na dissertação de mestrado (TINÉ, 2001), não corresponda exatamente ao conceito de Schoenberg, mas trata-se de uma adaptação para estruturas baseadas na repetição. Ou seja, parece que a repetição é mais própria ao gênero modal por conferir um aspecto circular, principalmente quando não apresentam frases cadenciais claras, como nos exemplos étnicos dos Cocos e Catimbós.

Além disso, por vezes tais estruturas apresentam frases cadenciais modais que imitam a pontuação característica do tonalismo, mas evitando a sensível, como em A de Vera Cruz, A de Borandá, etc. Um dos poucos exemplos de Período ocorreu no refrão de Consolação, ou seja, exatamente na seção tonal da canção e, ainda assim, trata-se de um período irregular. Outro exemplo interessante foi o da seção A de Morro Velho, na medida em que era constituído de quatro frases diferentes ( $a, b, c$ e $d$ ), mas com a quadratura regular (16 c.), figurando, portanto, como um exemplo do proposto verso branco musical. Cabe lembrar que na dissertação de mestrado, por tratar-se de um material eminentemente tonal, ocorreu o contrário: a predominância do período sobre a sentença.

Do ponto de vista das relações entre as fundamentais de cada seção, percebe-se que raramente foi utilizada a região da subdominante (Baião) nas seções $\mathrm{B}$, foram mais freqüentes os parentescos do relativo maior (Consolação, Berimbau), homônimo maior (Canto de Ossanha), homônimo menor (Canção do Sal), seções médias contrastantes modulantes (Borandá, Chegança) ou os casos baseados em vamps, como em Arrastão, com a seção B na

\footnotetext{
${ }^{142}$ Gravado pela primeira vez nos Estados Unidos da América em disco de Moreira, Airto. Natural Feelings. Sky Records, 1970.
} 
região da subtônica e Morro Velho, que se divide em dois procedimentos de modalismo híbrido. Nos casos ligados aos autores das décadas Gonzaga \& Jackson, só houve exploração de regiões contrastantes em Baião - as outras canções baseiam-se em uma só tonalidade durante toda a canção.

\subsection{Procedimentos Rapsódicos na Construção dos Arranjos e o Papel da Improvisação}

Alguns aspectos importantes devem ser mencionados em relação à forma nos arranjos abordados. Em primeiro lugar, o fato de que a distribuição dos elementos musicais é mais pertinente, no caso da música popular, à gravação do que à partitura, quando ela existe. Vê-se que, nos casos estudados no capítulo de Jackson do Pandeiro, as músicas eram arranjadas praticamente em função da letra, que na maioria dos casos era constituída por um refrão sucedido por estrofes que, embora musicalmente iguais, apresentavam diferentes versos. Quer dizer, não havia improvisos, as introduções eram bastante reduzidas. Os interlúdios instrumentais, quando ocorrem, trata-se de uma seção que, ao invés de cantada, é tocada por algum instrumento, geralmente a sanfona (acordeão).

Essas características também ocorreram em Luiz Gonzaga, mas com a ausência do refrão nos exemplos estudados. Raras foram as situações de modulação, e também não ocorrem transposições de seções. Ou seja, a simplicidade da distribuição dos elementos musicais os colocam bastante próximos às fontes étnico-musicais. Neste ponto é importante diferenciar a modulação que é inerente à composição, demonstrada acima quando se comentou sobre as relações entre as partes, daquelas modulações realizadas pelo arranjador (ou às vezes pelo intérprete), a fim de se dar fôlego à execução.

Já o universo carioca da década de 1960 introduz alguns elementos nos arranjos, como a improvisação nas versões escolhidas de Consolação, Berimbau e Borandá. Nos exemplos estudados, a improvisação figura em pequenas seções e, principalmente, nos vamps, às vezes como evoluções rítmicas, como no caso de Baden. Como este é o único intérprete instrumentista aqui escolhido, é possível que o papel da improvisação na época estudada não esteja devidamente representado. Entretanto, nota-se que nesses casos a improvisação não ocupa grandes e repetidos chorus, como no caso jazzístico. Mesmo importantes gravações de música instrumental ligadas à bossa nova do período não apresentam longas seções de 
improvisação, como nos álbuns Você Ainda Não Ouviu Nada ${ }^{143}$, de Sérgio Mendes e Bossa Rio, Inútil Paisagem ${ }^{144}$, de Eumir Deodato, e o citado Coisas, de Moacir Santos.

A transposição de tonalidade de uma mesma seção como procedimentos específicos do arranjador em Canto de Ossanha e Canção do Sal e a mudança de andamento em Arrastão e Vera Cruz também parecem enriquecer o leque de procedimentos adotados na década.

Quando se compara o procedimento formal na construção do arranjo no repertório estudado com o da tradição jazzística percebe-se que, no último caso, dá-se principalmente o procedimento “variação”, cuja matriz principal é a improvisação, elemento aculturado na Brasil principalmente através da bossa nova. Quando se vêem as análises formais de diferentes arranjos de diferentes décadas de clássicos do jazz realizados em obras como Changes Over Time ${ }^{145}$ e Inside Score ${ }^{146}$, percebe-se que uma série de solos escritos, espaços para improvisação e solis em naipe são formados na maioria das vezes respeitando-se a estrutura do chorus ou da canção propriamente dita. Tais estruturas são às vezes totalmente, às vezes parcialmente transposta para outras tonalidades.

No caso brasileiro, esta estrutura da canção é raramente mantida, o que leva a um procedimento basicamente rapsódico de colagem de seções. Por outro lado, este procedimento também esteve associado historicamente à improvisação.

O nome "rapsódia” sugere uma improvisação. [...] A excelência de uma
improvisação assenta-se mais em seu inspirado imediatismo e vivacidade do
que em sua elaboração. É claro, a diferença entre uma composição escrita e
improvisada é a velocidade de produção [...] Assim, sob condições
apropriadas, uma improvisação pode ter a profundidade de elaboração de
uma composição cuidadosamente trabalhada. Geralmente, uma improvisação
irá apegar-se a seu tema mais pelo exercício da imaginação e emoção do
que, propriamente, das faculdades estritamente intelectuais. Haverá uma
abundância de temas e idéias contrastantes cujo efeito total se adquire por
meio de rica modulação e regiões remotas. A conexão entre temas de
natureza tão diferenciadas e o controle da tendência centrífuga da harmonia
são, em geral, obtidos de maneira casual, por meio de "pontes" e, inclusive,
justaposições abruptas. (SCHOENBERG, 2004, p.198)

Essa natureza, de colagem de material, de junção de seções tonais com modais, também foi própria ao nacionalismo latino-americano que, exatamente por tais características, foi duramente criticado.

\footnotetext{
${ }^{143}$ Rio de Janeiro: Dubas Música, 1964.

${ }^{144}$ Rio de Janeiro: RCA Victor, 1964.

145 STURM, 1996.

${ }^{146}$ WRIGHT, 1982.
} 
Outro elemento que explica também o parentesco estrito entre os nacionalistas latino-americanos [...] será a ênfase dada ao realismo direto, o brilhantismo da orquestra e a pequena elaboração das obras (muitas vezes escritas de modo rapsódico). Se compositores como Carlos Chaves, Domingos Santa Cruz, Ginastera e alguns outros sabem dar às suas obras estruturação formal de elaboração mais inteligente (dentro dos critérios da música européia), a maioria dos compositores latino-americanos, inclusive grande parte dos nacionalistas brasileiros, parece não dominar totalmente os segredos da estruturação forma [sic.] da tradição ocidental, contentando-se em juntar temas aparentados ao modo a lembrar velhas peças de salão [...] ou intermináveis suítes rapsódicas. (NEVES, 1981, p.48)

Por outro lado, pode-se perguntar se tal procedimento não seria o modo próprio de distribuição formal do material popular, na medida em que a aplicação de formas tradicionais também foi criticada pelo mesmo autor. Talvez não seja por acaso que um cancioneiro como George Gershwin, quando almejou compor obras de concerto, tenha começado pela Rapsódia em Blues. O próprio Tom Jobim, quando sai da forma canção da bossa nova para processos mais “regionalistas” em Quebra-Pedra ${ }^{147}$ e mais recentemente em Pato Preto ${ }^{148}$, não deixa de adotar uma construção na base de “colagem” de material de inspiração étnica, ainda que associada a um processo de harmonização procedente do período que o destacou.

Vale ressaltar aqui o papel fundamental do arranjador e pianista do grupo Tamba Trio, Luiz Eça, que foi responsável pelos arranjos de dois álbuns de referência para este trabalho: o primeiro disco de Edu Lobo, no qual atua também como instrumentista, e o primeiro de Milton Nascimento. Luiz Eça também lançou discos na função de arranjador e instrumentista como os antológicos Luiz Eça \& Cordas em diversos volumes, além de parcerias com o Quinteto Villa-Lobos na década de 1970.

Outro dado relevante é o de que três dos álbuns de referência foram lançados na época pelo selo Elenco: Baden à Vontade, Edu Lobo por Edu Lobo e Afro-sambas. De pequeno porte e pertencente ao produtor Aluízio de Oliveira, foi um dos poucos exemplos até certo ponto bem-sucedidos de produção alternativa da década de 1960. São famosos os encartes que, em sua maioria, eram em preto-e-branco por questões econômicas, para se ter uma idéia das limitações. Entretanto, além dos álbuns citados, o primeiro disco de Tom Jobim pela Verve $^{149}$ foi lançado no Brasil pelo selo Elenco, além do primeiro disco de Egberto Gismonti, um dos volumes citados de Luiz Eça \& Cordas, entre muitos outros.

\footnotetext{
147 JOBIM, 1970.

${ }^{148}$ CHEDIAK, 1991. p. 82,83,

${ }^{149}$ Selo norte-americano de jazz.
} 
Por último, vale ressaltar a importância da intérprete Elis Regina na popularização de Arrastão e Upa, Neguinho, na época dos festivais, e pela mencionada gravação de Canto de Ossanha e Vera Cruz no álbum citado Como e Porque. 


\title{
7. Considerações Finais
}

Nesse ponto, quase final do trabalho, pretende-se tecer alguns comentários que vão além do período restrito pela pesquisa, principalmente no que tange o repertório popular.

\section{1 Milton: o Rock e o Folclore}

O caso do compositor Milton Nascimento permanece, em parte, uma incógnita. Se não foi possível relacionar as características de sua obra com o folclore mineiro, apenas recentemente essas conexões passaram a ser realizadas em álbuns como Tambores de Minas. Ainda que tais características estejam colocadas dentro do contexto da globalização da década de 1990, juntamente com a dos compositores Sting, Paul Simon, Peter Gabriel, entre outros, que se apropriaram de grupos étnicos emblemáticos preexistentes e terminaram, segundo o antropólogo Jorge de Carvalho, por descaracterizá-los:

\begin{abstract}
Milton Nascimento, uno de nuestros principales cantantes populares, es um negro del estado de Minas Gerais que después de dos décadas de gran fama em el Brasil pasa a formar parte de um circuito internacional de músicos populares, siguiendo la línea de la world music. Comienza a circular entonces entre músicos denominados “transnacionales" y em cierto momento vuelve a verse a si mismo, a partir de uma política de identidad musical norteamericana o británica, como um negro de Minas. Luego recorda que en Minas existe el Congado, que es la tradición ritual negra católica, musicalmente muy rica. Entonces lanza um disco intitulado Los Tambores de Minas em el qual se viste de rey de Congo [...] e canta unas canciones sagradas de Congado, em portugués. Ahora los músicos de los Congados están muy sorpreendidos y aturdidos, hasta perturbados com lo que pasa, porque sus canciones tienen um sentido esotérico, secreto, pero las cantam em portugués. Por doscientos años su repertorio [...], pertenecía somente a ellos, y nunca interesó a los productores y consumidores de la música popular escuchar la música del Congado [...] Cuando, para atender a uma necessidad de canabalización de la música contemporánea, Milton Nascimento pone uma canción del Congado em su disco, muchos otros músicos, menos famosos, pasan a imitar su gesto y también quieren apropiarse de esas canciones para vender discos. (J. de CARVALHO, 2003, p.7)
\end{abstract}

Como se sabe, na década de 1970, uma geração de compositores e letristas mineiros trabalharam juntos em diversos discos e esse grupo, denominado Clube da Esquina. Muitos álbuns se tornaram emblemáticos e referenciais, como o próprio Clube da Esquina, gravado em 1972. Se, por um lado, nota-se a apontada dissociação entre gênero rítmico e melódico em Vera Cruz, percebe-se que Milton trabalha dentro de algumas práticas comuns daquela época, 
como o caso da cadência melódica 4-2-1 no $4^{\circ}$ modo (cad. a) que Edu Lobo usou em Upa, Neguinho. Outro exemplo se encontra na harmonia da seção B de Canção do Sal, que é muito semelhante a da seção A de Canto de Ossanha. Mello (2003) relata que Milton participou como intérprete no II Festival da TV Excelsior, de 1966, defendendo a canção Cidade Vazia, de Baden Powell e Lula Freire. ${ }^{150}$

Por outro lado, o Clube da Esquina foi notabilizado por introduzir elementos do rock e do pop em sua música, como demonstra a canção Para Lennon e McCartney (Milton Nascimento, Márcio e Lô Borges) no quarto disco Milton (Odeon, 1970). Segundo Caetano Veloso,

[...] não fui capaz de detectar a grandeza musical de seu trabalho, num primeiro momento. [...] e não via ali muito além de um desenvolvimento daquilo que Edu Lobo já vinha fazendo de interessante, ou seja, um desdobramento da bossa nova que abrangia estilização das formas nordestinas. Claro que, em breve, veria que muito do que nós baianos havíamos sublinhado - a saber o rock, pop, sobretudo Beatles, além da América espanhola - também estava incorporado ao repertório de interesses de Milton."151

Entretanto, através da obra de Borges (1996), constata-se que tais interesses se deram através dos compositores de gerações mais jovens que Milton e Toninho Horta, Lô Borges (irmão mais novo do letrista) e Beto Guedes. Tal fato parece apontar para o dado de que, quando Milton começou a gravar e compor dentro da atmosfera do pop-rock, ainda que pudesse trazer alguns elementos modais, o estilo com as características principais do compositor Milton Nascimento já estavam formados. Além disso, caberia investigar qual subgênero do rock ou pop teria tais características modais já que, tomando-se os Beatles como exemplo, existe uma grande quantidade de diferentes tendências musicais abordadas, modais e tonais, principalmente após o antológico álbum Sgt Pepper's Lonely Hearts Club Band (1967).

Já a mencionada América Espanhola pode ter sido outro fator gerador de procedimentos modais. O fato de cantar juntamente com a cantora argentina Mercedes Soza, interpretar canções como Dos Cruces e adotar uma rítmica latina em San Vicente ${ }^{152}$, pode ter sido uma vertente que corroborou com o mencionado “despontar do frígio” em sua música.

\footnotetext{
${ }^{150}$ Desiludido com o ambiente musical dos festivais, só voltou à cena no "II FIC/TV Rio” no ano seguinte, quando sua canção mais famosa, Travessia, ganhou $2^{\circ}$ lugar, tendo sido inscrita à revelia do autor.

${ }^{151}$ VELOSO, Caetano apud BORGES, Marcio: 1996, p.13-14.

${ }^{152}$ Ambas presentes no álbum Clube da Esquina. Odeon, 1972.
} 
Por outro lado, é com Milton Nascimento que acontecerá uma sintonia com o jazz da época. Foi encontrada uma série de procedimentos melódicos embasados em manifestações étnicas harmonizadas, tanto tonalmente à bossa nova quanto com o recurso da cadência modal. Embora negro, Milton não compõe afro-sambas baseados na escala pentatônica. Entretanto, a introdução instável de Vera Cruz ou a seção B de Sentinela, lançada em 1969 no disco Milton Nascimento (Odeon), apontam para aquele tipo de harmonia modulatória baseada em acordes saturados modalmente, que não têm relação entre si através de campo harmônico ou de relação dominante-tônica, mas sim oscilações de meio-tom, transposições de tipologias e o uso do sus não cadencial, tal como apontado em Maiden Voyage. Após estabelecer claramente o $6^{\circ}$ modo (eólio) em mi através da seção A e Refrão (IVm7-Vm7Im7-Isus7), segue-se a referida seção:

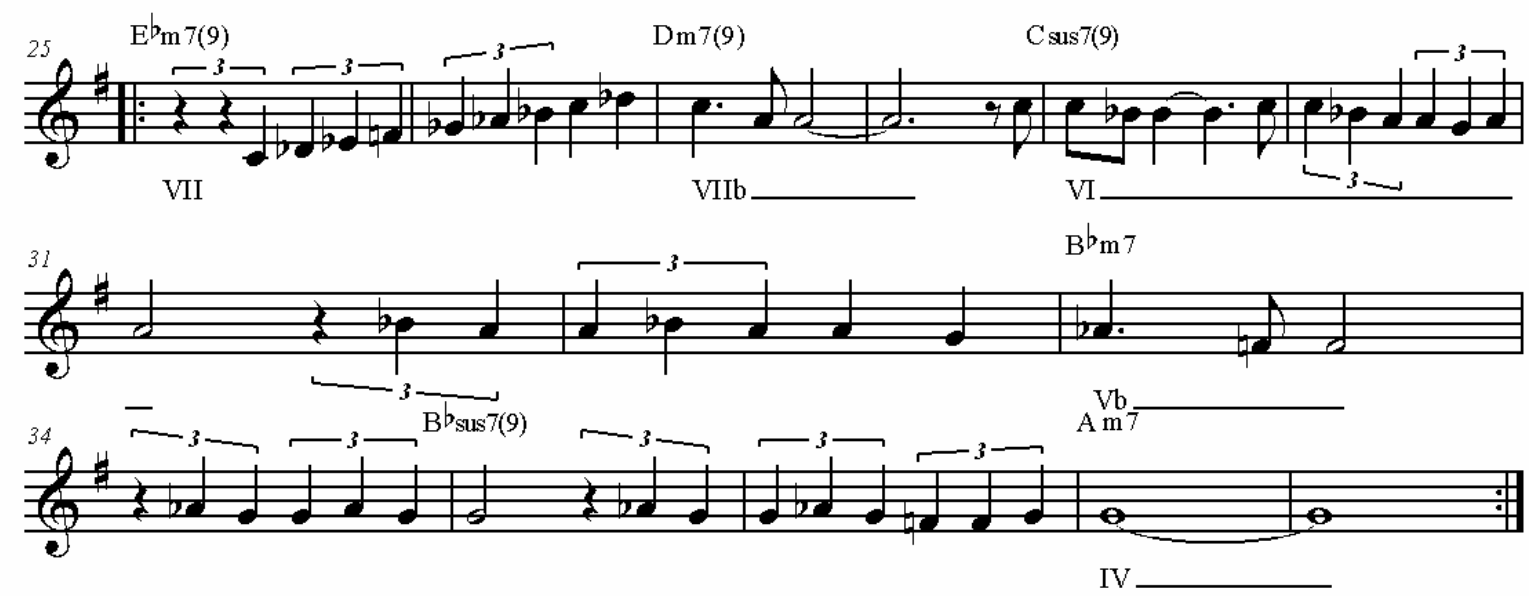

Fig. 7.1 Sentinela, seção $\mathrm{B}^{153}$

Todos esses procedimentos somados podem ter encantado os jazzistas daquele período que, posteriormente, trabalharam juntamente com Milton, como o saxofonista Wayne Shorter no álbum Native Dancer (Columbia, 1975).

Há ainda, na obra de Milton, uma série de elementos que remetem ao estado mineiro, além da sua ligação com o Clube da Esquina. Embora não se tenham encontrado elementos étnicos específicos de Minas Gerais em sua obra, uma série de elementos poéticos perfaz esta conexão. Por exemplo, as montanhas nas capas dos discos Minas e Geraes associadas à figura do trem. Este último é uma figura recorrente nas letras de suas canções, como a analisada Morro Velho e Ponta de Areia ou Encontros e Despedidas, entre outras. Parece haver um viés

\footnotetext{
${ }^{153}$ A escrita rítmica é aproximada na medida em que o autor-intérprete tem uma absoluta liberdade rítmica na gravação de referência.
} 
nostálgico no uso desta imagem, aliado à dimensão de separações e encontros promovidos por esse meio de transporte. Mas, além disso, uma certa ligação saudosa com o passado nos versos que ligava Minas ao porto, ao mar/ Caminho de ferro mandaram arrancar. A imagem poética parece mudar completamente quando se substitui a estação de trem pela rodoviária, por exemplo, como faz Chico Buarque.

\subsection{Tropicália}

Como se sabe o movimento tropicália veio de certa forma tentar romper com uma dicotomia existente na música popular do Brasil da década de 1960: de um lado o movimento bossa nova e sua continuação através da canção de protesto, e do outro a jovem guarda e o rock.

Ora, essa evolução realmente algo equivocada dos músicos continuadores da bossa nova, baseada na preocupação politicamente bem intencionada, mas idealista, de abolir as fronteiras de classe para se aproximar de um povo in abstrato, além de dividir o movimento [...], conduzia a música da classe média a um impasse. [...] E, o que agravava ainda mais a contradição - [...] -, o súbito apego da ala nacionalista da bossa nova à tradição do samba urbano e dos temas rurais colocava-a em choque com a nova tendência da música internacional do momento, representada em dois planos pelo rock sofisticado dos Beatles, consumido pelas classes mais altas, e sua diluição comercial dirigida às camadas mais amplas pelo iê-iê-iê de Roberto Carlos. (TINHORÃO, 1998, p.324)

Assim, a tropicália trataria de incorporar os elementos musicais do rock, sem necessariamente negar o legado da bossa nova, embora tenha havido algumas tensões principalmente entre os representantes mais jovens do que Tinhorão chamou de "ala nacionalista”, como Geraldo Vandré. O próprio Caetano Veloso se definiu assim, no contexto da época:

[...] mas eu sou baiano (amante das aparências) e estava engajado num programa de regeneração da música brasileira através da carnavalização do deboche, e do escândalo - através da paródia e da autoparódia [...] (VELOSO apud BORGES, 1996, p.14)

Entretanto, como será que todo este processo se dá musicalmente? Conforme argumento na referida dissertação de mestrado, Pixinguinha foi criticado na época do lançamento da gravação de Lamentos por ter supostamente composto um fox-trote; entretanto, 
o que acontecia ali era o uso de uma instrumentação característica do estilo New Orleans e Dixieland e não uma composição dentro das características gêneros. Segue abaixo um trecho da melodia da música Tropicália, carro-chefe do movimento:

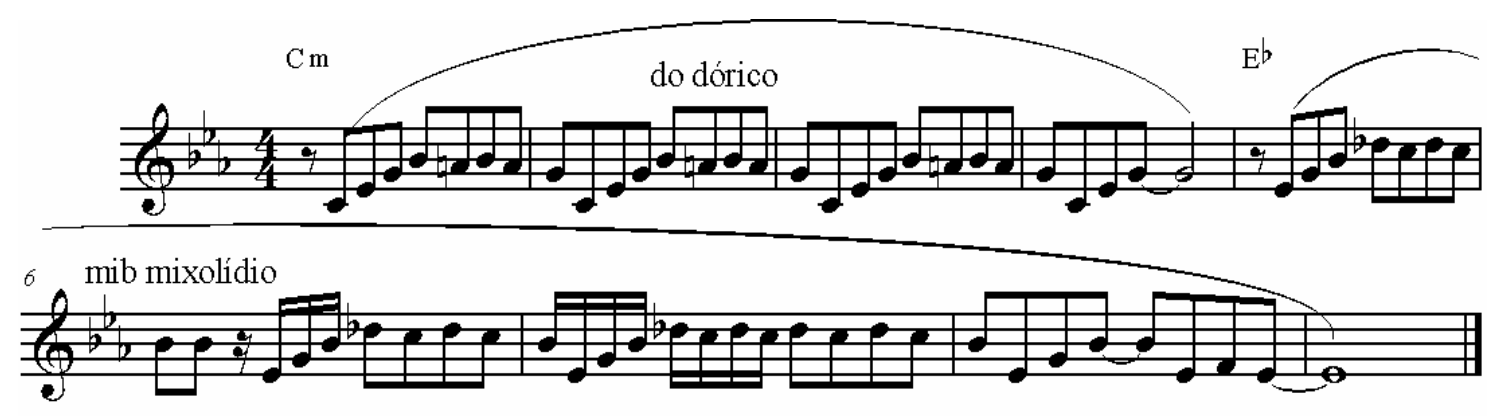

Fig. 7.3 Tropicália ${ }^{154}$

O exemplo acima não difere muito daqueles mostrados durante este trabalho, principalmente aqueles do Capítulo 4 (Gonzaga e Jackson): a primeira frase no $2^{\circ}$ modo e a segunda a partir do acorde relativo no $5^{\circ}$ modo têm exatamente o mesmo contorno inicial de Baião.

Outro compositor de extrema importância para o movimento foi Gilberto Gil. Este parece ainda mais arraigado em tradições musicais que apontam, de um lado, para a música nordestina e, após o período de exílio, para o lado afro da Bahia, principalmente Salvador, através de sua aproximação com afoxés tradicionais, como Filhos de Gandhi através de canções com temáticas afins como Afoxé é, Axé Babá, Babá Alapalá, Logunedé, etc. Sua canção emblemática do tropicalismo foi Domingo no Parque:

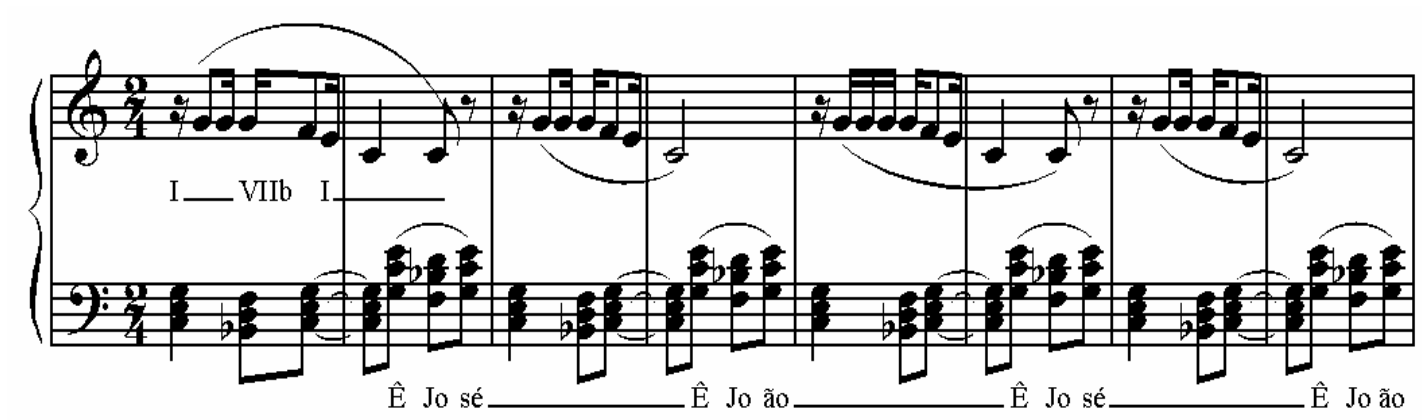

Fig. 7.4 Domingo no Parque - trecho ${ }^{155}$

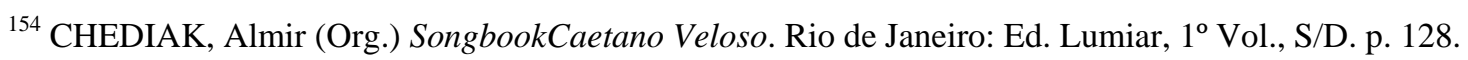


Apesar de a melodia ser aparentemente tonal, o acompanhamento é baseado no vamp I - VIIb - I do $5^{\circ}$ modo, ou seja, um priorização como se fosse uma transposição da bordadura melódica 1-7+1 no modo mixolídio ao nível harmônico. Além disso, ressalte-se a construção musical em responsório, afora o fato de que a rítmica assemelha-se ao do toque de berimbau pela síncopa entre um compasso e outro.

Essa canção foi defendida por Gil acompanhado pelo conjunto Os Mutantes. Portanto, é bem provável que a introdução de tais elementos estrangeiros se dê, pelos menos nestes casos e compositores, ao nível da instrumentação e “roupagem” musical. Por outro lado, se de alguma forma os compositores tentaram dissimular tais brasilidades com a introdução desses instrumentos, numa tentativa de se oporem aos defensores da então chamada música popular brasileira, é certo que suas identidades e heranças musicais intuitivamente afloraram. De qualquer forma, essa seria uma pesquisa a ser realizada.

\subsection{Depoimentos de Edu Lobo}

No recém-lançado DVD Vento Bravo (2007), com show e documentário sobre o autor, Edu Lobo tece considerações esclarecedoras a respeito de sua obra dentro do contexto histórico abordado e também sobre suas influências étnicas. Declarações semelhantes em outros depoimentos em vídeos similares de Baden e Milton não foram tão significativas para este trabalho. Transcrevem-se abaixo algumas declarações do compositor nesse DVD. Como se sabe, Edu Lobo é carioca filho de pais pernambucanos e passava as férias em Recife e traduz assim suas impressões:

Olha, lembro muito de uma coisa que não existe mais, que eram os pregões, as pessoas passando, vendendo os produtos, cada produto tinha um pregão. Tem poucos que eu me lembro. [...] E aquelas músicas e aqueles sons, e aqueles negócios e aí tinha Caruaru e a Banda de Pífanos, que é um negócio impressionante de bonito, uma flauta de madeira, um cara tocando bumbo e o outro triângulo e cantando com aquelas vozes. Fora isso a escala nordestina, que tem uma quinta diminuta que é um negócio espetacularmente moderno pra uma música popular. [...] Isso tem na música deles, que deve ter sido dos mouros, provavelmente [...]

Edu está se referindo, provavelmente, ao $4^{\circ}$ modo diatônico puro (lídio) ou ao modo híbrido chamado Lídio 7b ou mixo4+ (11+). Nesse momento ele canta o seguinte pregão de memória:

${ }^{155}$ Idem. Songbook Gilberto Gil. Rio de Janeiro: Ed. Lumiar, $1^{\text {o }}$ Vol., S/D. P. 128. 


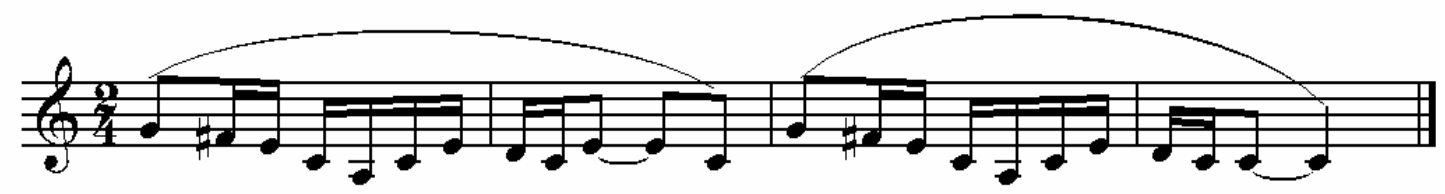

Fig. 7.5 Pregão

Como se pode verificar, esse pregão encontra-se no $4^{\circ}$ modo devido à presença da quarta aumentada. Mais adiante o autor fala sobre a infância e o carnaval em Recife.

Carnaval que eu me lembre na minha vida foi em Recife sempre, não só de rua como festas também. [...] tinha muita coisa que passava em frente de casa: esses pregões, em época de carnaval grupinhos que passavam ali, era um bumba-meu-boi que tava lá. Enfim, aquele canto nordestino, aquele canto rachado, a história do frevo, do maracatu, essa linha melódica que sempre me interessou tanto e era tão natural pra mim mexer com ela. Era uma coisa natural, eu não tava forçando uma barra. Eu saí de uma coisa carioca, a bossa nova era uma coisa bem carioca e eu fui procurar uma coisa mais próxima a minha alma, meu coração.

Num outro momento do depoimento, Edu Lobo fala sobre o impacto da primeira audição de Chega de Saudade, música símbolo da bossa nova:

Outra coisa que eu me lembro, que foi em Recife também, foi a primeira vez que eu ouvi o Chega de Saudade, que eu fiquei muito impressionado. Primeiro era uma voz que eu nunca tinha ouvido nada parecido [...],, um violão completamente novo, uma música completamente diferente das outras músicas, completamente diferente do Caymmi, do Ari, do Noel. A música do Tom, a letra do Vinícius, João Gilberto cantando, tocando aquele violão, aquelas divisões, o arranjo do Tom [...] Eu fiquei completamente paralisado, assim de gostar tanto e de querer compreender, porque era muita coisa nova ao mesmo tempo.

Edu passa então a falar da fusão dos elementos da bossa nova com a herança musical pessoal da tradição do Nordeste. Há nesse DVD uma série de depoimentos de outros músicos e críticos. Dentre eles Tarik de Souza que enfatiza a importância do legado de Luiz Gonzaga e comenta o fato de que muitos compositores da geração de Edu, como João Donato e Eumir Deodato, tiveram sua iniciação musical através da sanfona por causa do grande sucesso dos baiões do autor pernambucano. 
Eu acho que essa idéia de misturar as coisas da bossa nova com as coisas do nordeste foi quase que uma coisa de sobrevivência mesmo porque eu convivia com pessoas cuja barra era muito pesada. Através do Vinícius eu conheci o Tom, conheci o Carlinhos Lyra, conheci o Baden, se eu entrar nessa área aqui eu sou expulso de campo, num dá tempo pra mim. Porque a barra era muito pesada, os caras eram muitos craques. [...] Então eu acho que eu fui tentando pegar esses sons que tavam na minha cabeça, fazia uma espécie de adaptação com as harmonias novas que eu tava apreendendo, apreendendo todos os dias, todos os dias tinha uma harmonia nova.

Sobre o impacto do violão de Baden Powell, com a 6a corda afinada em ré e sobre sua posterior parceria com Vinícius de Moraes, Edu Lobo diz o seguinte:

Não conhecia nenhum violão parecido com esse do Baden, não conhecia não. Depois, conheço vários, inclusive o meu. [...] Essa parceria com Vinícius foi fundamental. A impressão que eu tinha era que tinha alguém assinando um documento muito importante pra minha vida.

Outro trecho importante é sobre o tropicalismo e, em seguida, sobre o chamado Clube da Esquina:

Eu não briguei com ninguém da tropicália, nem com Caetano nem com o Gil. Eu sempre gostei muito do que eles faziam, desde que eles chegaram. Existia um lado da tropicália que eu não achava muita graça, a coisa mais teatral, mais de evento, eu acho que era uma mudança de comportamento, uma espécie de dadaísmo. Tinha um grupo de Minas, que eu sempre falo também, chamava Clube da Esquina, que foi importantíssimo pra música, e ninguém se refere a esse grupo quando dividi a música. Eu estava prestando muito mais atenção nessa escola mineira do que na tropicália, isso é verdade.

Parece que os pontos de vista pessoais expressados pelo autor coincide com os demonstrados, não somente através das análises deste trabalho como na própria escolha dos compositores de referência, dentro de um jogo multifacetado de influências. Entretanto, há que se considerar que esse grupo chamado Clube da Esquina não formava, e possivelmente nem pretendiam formar, um todo coerente. O viés modal parece ser exclusivo de Milton Nascimento. Em outro compositor de sua geração, Toninho Horta, o viés é completamente tonal, ainda que com cadências derivadas e expandidas do jazz em clássicos como Beijo Partido, Aqui, Oh, Durango Kid, para citar aquelas gravadas por Milton na primeira década de carreira. Portanto, Milton permanece numa posição de destaque e, de certa forma, de catalisador de músicos mineiros ao seu redor. Ao mesmo tempo, é bastante interessante a contestação por parte de Edu de uma linha divisória da música popular brasileira da época através somente do movimento tropicalista. 
Outro importante dado contado nesse DVD é o fato de que a canção Zambi, cujos trechos estão se mostrando durante a conclusão deste trabalho, foi o mote para a construção da peça Arena Conta Zumbi.

Sobre Tom Jobim, o compositor diz o seguinte:

Eu não conheço nenhum compositor brasileiro, sei que tem muitos, tão bom quanto o Tom. [...] Tem um tipo de compositor que ele meio que te coloca trabalhando, ele faz com que você trabalhe, ele meio que te empurra na direção do trabalho. O Villa é um desses casos, como eu acho que o Tom fez com a minha geração inteira, acho que é um compositor que fez agente trabalhar, de uma forma indireta, sem dar ordens nem coisa nenhuma.

Na década de 1970, Edu Lobo fez uma versão com letra para o famoso O Trenzinho do Caipira, da série Bachianas Brasileiras $N^{o} 2$ de Heitor Villa Lobos, com letra de Ferreira Gullar. Sobre o compositor, Edu Lobo diz o seguinte:

Villa Lobos é o som do Brasil. Acho que o cara que fez a trilha do Brasil foi o Villa Lobos. Quando eu vejo alguma coisa de imagens, de coisas bem brasileiras, eu fico ouvindo aquele som que ele inventou, aquele som que é absolutamente brasileiro e lindo, que tem uma tristeza que deve ser herança portuguesa, não sei direito de onde é que vem, mas é um som que é o som do Villa.

Pesquisas posteriores podem apontar o grau de ascendência da obra de Heitor Villa Lobos sobre compositores de cunho popular como Tom Jobim, Edu Lobo e Egberto Gismonti, a fim de conferir especificamente onde esses traços ocorrem do ponto de vista musical.

\subsection{Hermeto Pascoal: Síntese dos Procedimentos}

O compositor alagoano, além de participar ativamente do momento histórico definido como integrante do grupo Quarteto Novo, na década de 1960, corrobora em sua práxis de improvisação e composição para uma síntese dos procedimentos aqui demonstrados. Ao longo das análises, algumas referências foram mencionadas no sentido das recorrências na obra do autor. Por exemplo, o uso do vamp IV7 - $\operatorname{Im} 7$ pertencente ao $2^{\circ}$ modo, utilizado em Forró Brasil, que consta do disco Live in Montreux (WEA Brasil, 1980). 


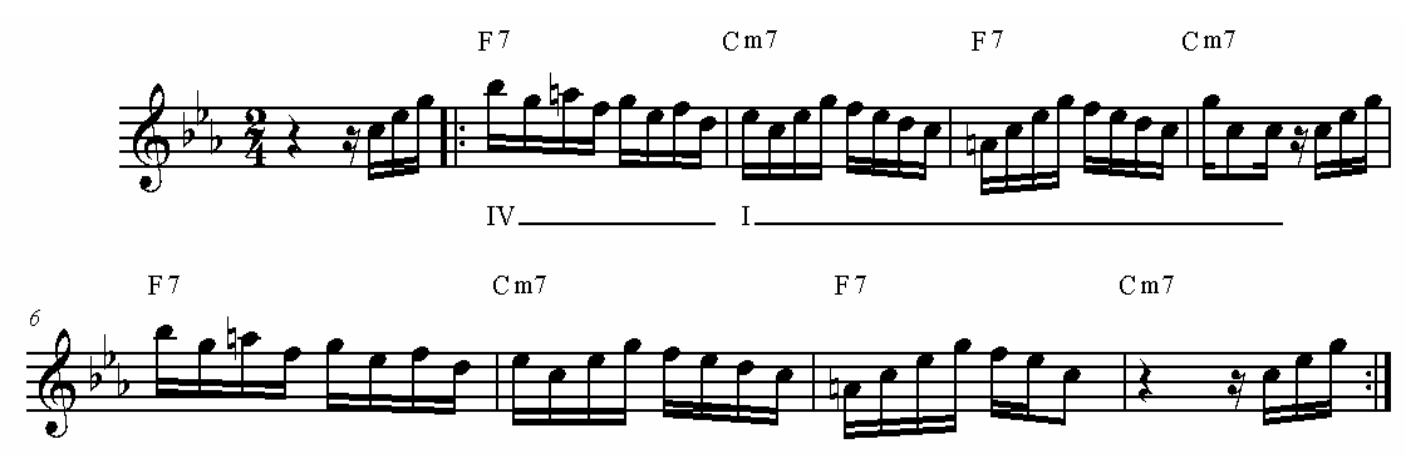

Fig. 7.7 Forró Brasil - trecho.

Outro exemplo é a mencionada dissociação entre gênero rítmico e modo ocorrida em Bebê. Além disso, seus improvisos apresentam uma série de elementos aqui diagnosticados que demonstram o quanto eles foram incorporados, através de toda uma vivência dentro dos gêneros musicais nordestinos, a ponto de serem colocados dentro de um improviso com a maior naturalidade.

O exemplo refere-se a uma análise de um improviso de acordeon retirado da dissertação de mestrado de Prandini ${ }^{156}$ para a música O Tocador Quer Beber, do álbum Brasil Universo (Som da Gente, 1985). Os ritmos foram retirados para que apenas os principais traços melódicos aparecessem. Observa-se a ocorrência dos mencionados traços cadenciais 6+1 retirado do $5^{\circ}$ modo puro e 4-2-1 retirado do $5^{\circ}$ modo híbrido (mixolídio com $4^{\text {a }}$ aumentada ou lídio com $7^{\mathrm{a}}$ menor). Também a ocorrência de notas repetidas ao modo dos Cocos. A letra $b$ indica bordadura, a abreviação arp. indica arpejo, normalmente referido por uma cifra, a abreviação esc. escala, algumas mencionadas no decorrer da análise. Os arcos indicam as frases e os números, além dos traços melódicos, o intervalo do final da frase em relação ao acorde do momento. A composição, tal como os baiões de Gonzaga, traz os acordes maiores com $7^{\text {a }}$ menor para o I e IV grau, mas aqui em vamp híbrido, com um acorde para cada compasso.

Se, como visto, a improvisação na música popular do Brasil na década de 1960 se dava através de pequenos trechos, normalmente associada a vamps, ao contrário do processo jazzístico que se dá no chorus inteiro, essa improvisação aqui mostrada, embora baseada na seqüência referida, é bastante longa, o que aponta para uma intensificação da apropriação do gênero norte-americano de improvisação por Hermeto Pascoal. É preciso ressaltar também que esse solo data da década de 1980, após muitos anos de decantação dos fatores implicados.

\footnotetext{
${ }^{156}$ PRANDINI, José Carlos. Um Estudo da Improvisação na Música de Hermeto Pascoal: Transcrição e Análise de Solos Improvisados. Dissertação de Mestrado. Campinas: Unicamp, 1996.
} 
Outro fato importante ocorre quando a escala não corresponde exatamente ao modo do acorde, $5^{\circ}$ modo diatônico puro (mixolídio) para cada acorde. Isso indica a predominância, nesses momentos, do pensamento melódico sobre o harmônico por parte do improvisador, fato que já ocorria em improvisadores de BeBop, como Charlie Parker.

\section{O Tocador Quer beber-solo}
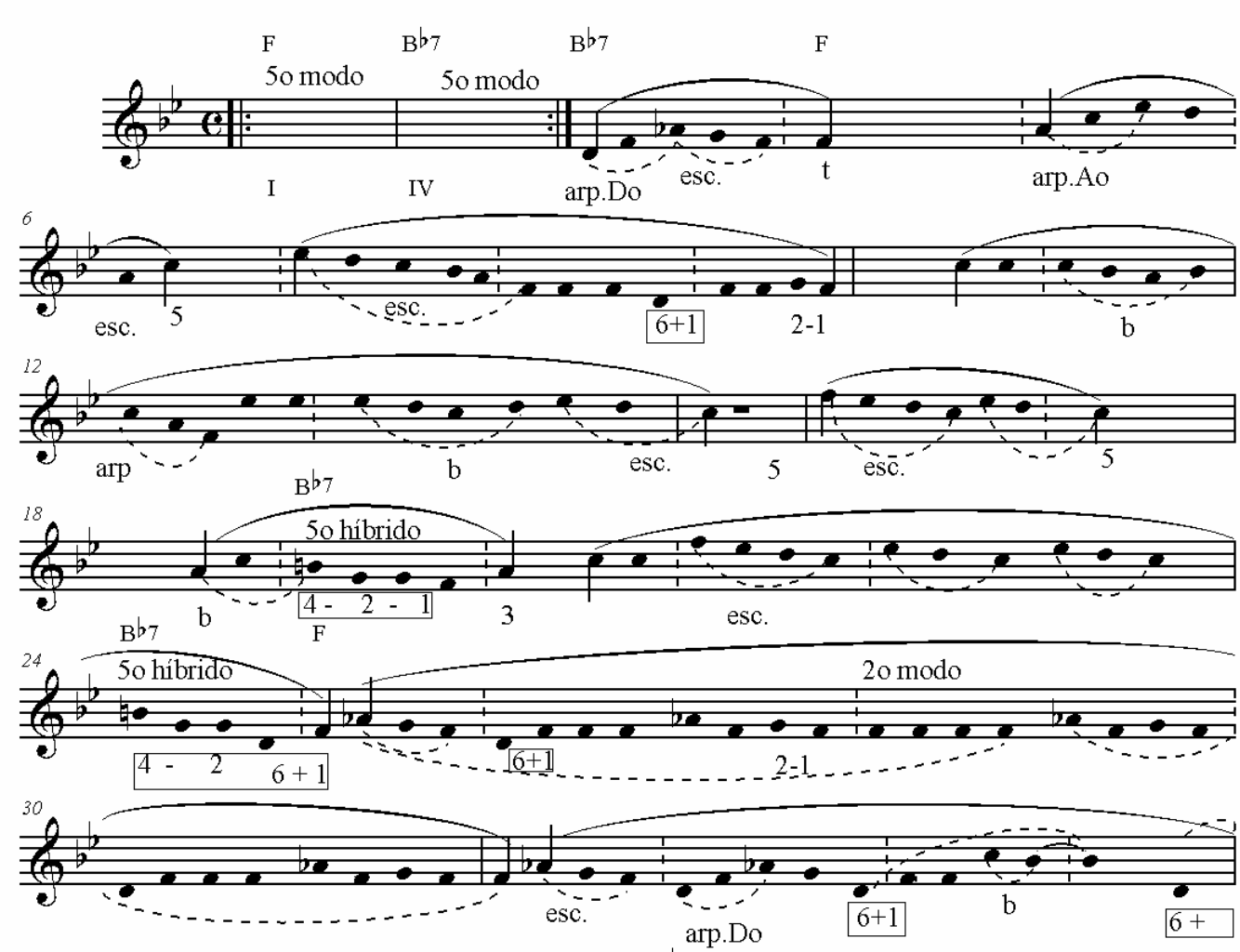

$\mathrm{B}^{\mathrm{b}} 7$
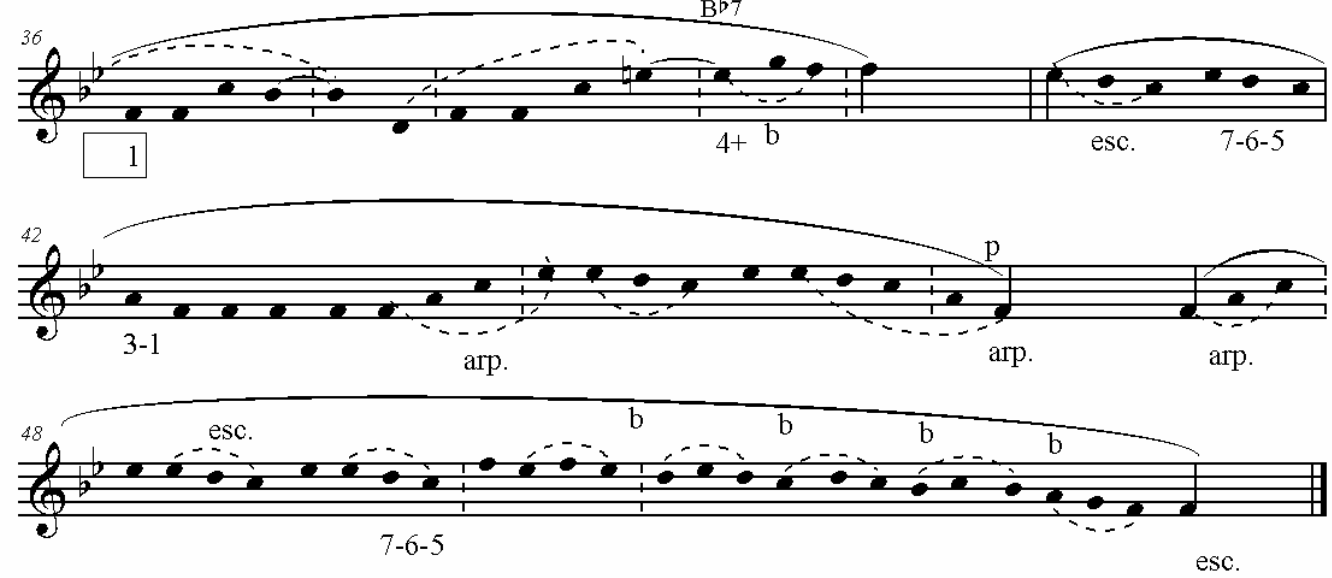

Fig. 7.8 O Tocador Quer beber - improviso. 
Dentro desse contexto de referência, o autor alagoano parece criar uma interessante categoria fraseológica em suas composições a qual poder-se-ia chamar de "verso livre musical”. Diferentemente do mencionado verso branco, o verso livre caracterizar-se-ia pela ausência de rima e métrica (GOLDSTEIN, 2005, p.36). No mencionado álbum Brasil Universo, o autor realiza na última faixa uma espécie de improvisação verbal com associação livre de idéias e de métricas preestabelecidas, uma espécie de repente livre. É o que o autor parece transpor para o nível musical puro na obra São Paulo, 9 de Julho, uma das 366 músicas de seu Calendário do Som (PASCOAL, 2000). 

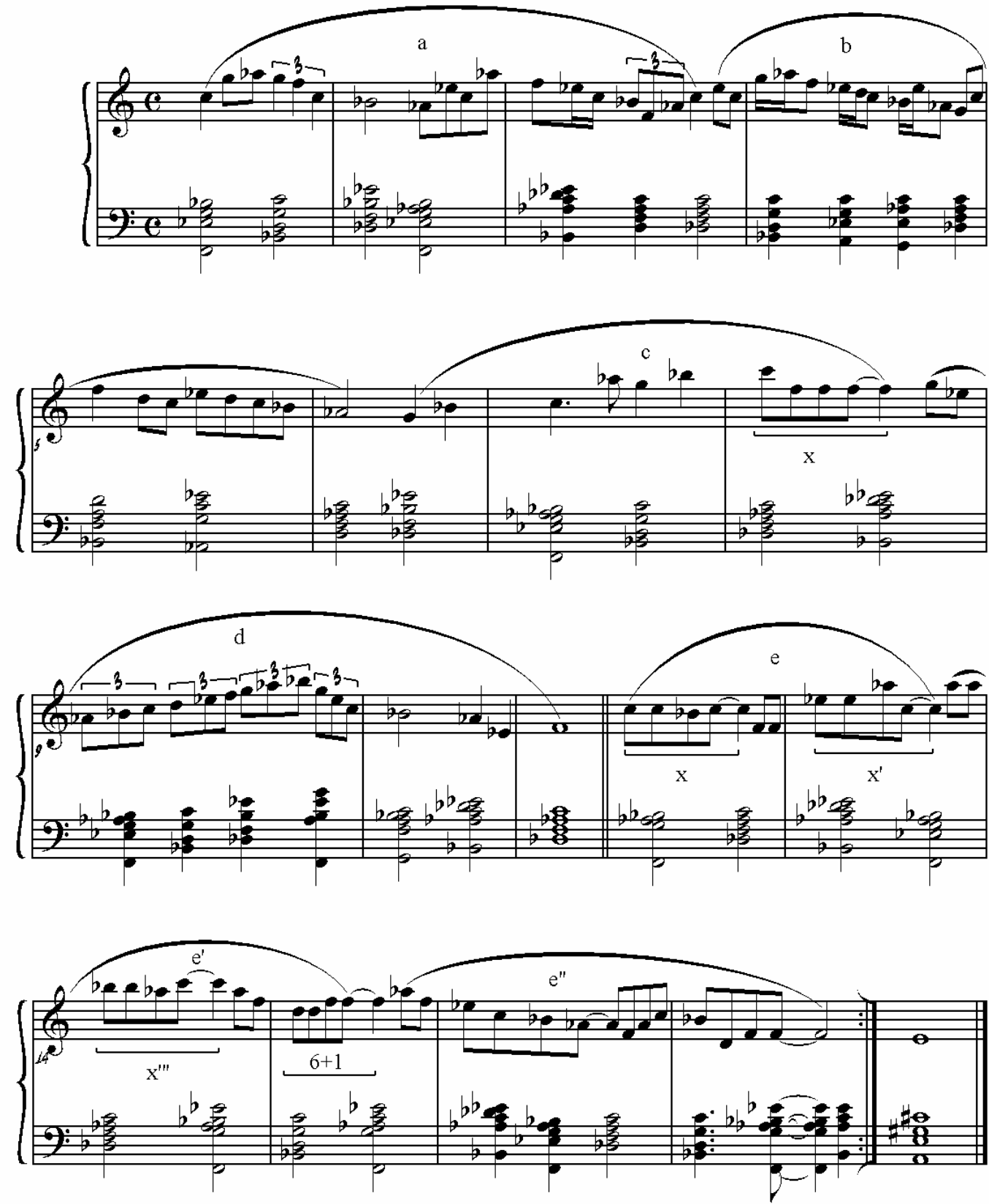

Fig. 7.9 São Paulo, 9 de Julho

Nota-se que até o final da frase $d$ no $11^{\circ}$ compasso não há nenhuma repetição fraseológica. É somente a partir do $12^{\circ}$ compasso com a seqüência de três frases, $e$ e derivadas, que há uma pequena estrutura ternária regular ocupando 6 compassos. É essa ausência de repetição fraseológica que caracterizariam o verso livre musical dos 11 primeiros 
compassos. Apenas o motivo $x$, e suas derivações, faz uma conexão desses mesmos compassos e os seis últimos (do $12^{\circ}$ ao $17^{\circ}$ ). Nota-se também que toda melodia está baseada num único modo de fá dórico, muito embora o compositor o harmonize das mais variadas maneiras. Ou seja, o autor realiza uma composição extremamente coerente sem lançar mão de repetições fraseológicas até o $11^{\circ}$ compasso e sem abdicar ao uso de um modo diatônico. Além disso, leva às últimas conseqüências as possibilidades idiomáticas, ligadas às tradições popular e jazzística de harmonização, além do uso do traço melódico característico 6+1. Outras composições de Hermeto parecem atuar na mesma direção, como Ilha das Gaivotas e Mestre Radamés, por exemplo.

Se se pode pensar que na década posterior ao período estudado Hermeto Pascoal e o compositor carioca Egberto Gismonti tiveram um importante papel tanto na música instrumental brasileira, quando em seu processo de renovação, bem como com a manutenção do uso de material étnico e popular em suas composições.

Ressalte-se que, enquanto Egberto buscou também utilizar ferramentas oriundas da erudição musical, tendo estudado com Nadia Boulanger e Jean Barraqué em Paris, o compositor alagoano expandiu-se musicalmente a partir “de dentro”, ou seja, a partir da própria saturação do material étnico e popular, seja através dos ritmos e melodias seja através dos processos harmônicos derivados do jazz e da bossa nova. Para tal, foi fundamental o período aqui estudado, já que o germe da produção do autor se dá na referida década e seu grupo, o Quarteto Novo que, como visto, figurou como importante apoio para Edu Lobo e Geraldo Vandré, conforme apontado.

Se o exercício musical de gêneros brasileiros foi, como apontado por Coli (In ANDRADE, 2006), um exercício de entendimento e de respeito da cultura do outro, a construção de uma identidade musical brasileira não deixa também de se construir - apesar de esta construção estar sempre em movimento e, simultaneamente, em desconstrução - através da alteridade. 


\section{Referências Bibliográficas}

ANDRADE, Mário de. Aspectos da Música Brasileira. Belo Horizonte/ Rio de Janeiro: Ed. Villa Rica, 1991.

Dicionário Musical Brasileiro. Coordenação: Oneyda Alvarenga, 1982-84, Flávia Camargo Toni, 1984-89. - Belo Horizonte: Itatiaia, [Brasília-DF] ; Ministério da Cultura; São Paulo: Instituto dos Estudos Brasileiros da Universidade de São Paulo: Editora da Universidade de São Paulo, 1989.

Ensaio sobre a Música Brasileira. São Paulo: Ed. Livraria Martins, s/d.

Missão de Pesquisas Folclóricas: Música Tradicional do Nordeste 1938. São Paulo: Sesc-Prefeitura da Cidade de São Paulo-Centro Cultural São Paulo, 2006.

Música de Feitiçaria no Brasil. Belo Horizonte: Itatiaia, 2. ed., 1983.

O Banquete. São Paulo: Livraria Duas Cidades Ltda, 1989.

Os Cocos. Belo Horizonte: Itatiaia, 2. ed., 2002.

Pequena História da Música. Belo Horizonte: Itatiaia, 9. ed., 1987.

BERENDT, Joachim. O Jazz do Rag ao Rock. São Paulo: Perspectiva, 1975.

BORGES, Marcio. Os Sonhos não Envelhecem - Histórias do Clube da Esquina. São Paulo: Geração Editorial, 1996.

CAMPOS, Augusto. Balanço da Bossa. São Paulo: Ed. Perspectiva, 5. ed.,1993.

CARLINI, Álvaro. Cachimbo e Maracá: O Catimbó da Missão (1938). São Paulo: CCSP, 1993. 
CARPEAUX, Otto Maria. Uma Nova História da Música. São Paulo: Livraria José Olympio Editora S.A, 2. ed., 1967.

CARVALHO, Any Raquel. Contraponto Modal. Porto Alegre: Ed. Sagra Luzzatto Novak Multimídia, 2000.

CARVALHO, Jorge de. La Etnomusicologia em Tiempos de Canabalismo Musical. Revista Transcultural de Música, N. 7, 2003. Disponível em http://www.sibetrans.com/trans/trans7/carvalho.htm. Acesso em julho de 2008.

CASCUDO, Luis da Câmara. Dicionário do Folclore Brasileiro. São Paulo: Global, 11. ed., 2002.

Cocos: Alegria e Devoção. Org. Maria Ignez Novais Ayala, Marcos Ayala. Natal: EDUFRN, 2000.

COLI, Jorge. O Nacional e o Outro. In: Andrade, Mário. Missão de Pesquisas Folclóricas, Música Tradicional do Nordeste. São Paulo: Sesc-Prefeitura da Cidade de São Paulo-Centro Cultural São Paulo, 2006.

CONTIER, Arnaldo Daraya. Edu Lobo e Carlos Lyra: o nacional e o popular na canção de protesto (os anos 60). Revista História de São Paulo, V.18, N. 35, p. 13 - 52, 1996.

Música e Ideologia no Brasil. São Paulo: Novas Metas, 2. ed., 1985.

DASILVA B., Fabio. Misleading Discourse and the Message of Silence: An Adornian Introduction to Villa-Lobo's Music. International Review of Aesthetics and Sociology of Music, V.10, N. 2 (Dec. 1979), pp 167-180.

DANIÉLOU, Alain. Sacred Music: Its Origins, Powers, and Future; Traditional Music in Today's World. Nova Deli: Indica Books, 2002.

Music and the Power of Sound: The Influence of Tunning and Intervalo on Consciouness. Rochester: Inner Traditions International, 1995. Cap. 5, p. 75-79. 
The Raga's of Northern Indian Music. Nova Deli: Munshiran Manoharlal Publishers Put. Ltda, 1980.

DREYFUS, Dominique. A Vida do Viajante: A Saga de Luiz Gonzaga. São Paulo: Ed.34, 1996.

FERNANDES, Florestan. O Folclore em Questão. São Paulo: Martins Fontes, 2003.

GREEN, Douglass M. Form in Tonal Music: an introduction to analysis. New York: Holt Rinehart and Wiston Inc., 1964.

HALL, Stuart. A Identidade Cultural na Pós- Modernidade. Trad. Tomaz Tadeu da Silva e Guacira Lopes Louro. Rio de Janeiro, DP\&A, 7. ed., 2003.

GAINZA, J. Javier Goldaráz. Afinación y temperamento en la música ocidental. Madrid: Alianza Editorial, 1992.

GOLDSTEIN, Norma. Versos, Sons, Ritmos. São Paulo: Ed. Ática, 13. ed., 2005.

GUEST, Ian. Arranjo. Rio de Janeiro: Lumiar, 1996.

Havard Dictionary of Music. $2^{\mathrm{a}}$ Ed., revisada e ampliada por Willi Apel. Massachusetts, Cambridge: The Belknap Press of University Press, 1976.

JARDIM, Roberto Gilmar. Bachianas Brasileiras No 7: O Estilo Antropofágico de Heitor Villa-Lobos. Tese de Doutorado. ECA-USP: São Paulo, 2002.

KAUFMANN, Walter. The Ragas of North India. New York: Da Capo Press, 1984.

KOSTKA, Stefan. Materials and Techniques of Twentieth - Century Music. New Jersey: Pearson, 3. ed., 2006.

KUMAR, KANTHIMATHI \& STACKHOUSE, Jean. Classical Music of South India. Stuyvesant (NY): Pendragon Press, 1987. 
LACERDA, Marcos Branda. Música de culto nagô-iorubá e a Barform. Anais do XIII Encontro Nacional da Anppom. Belo Horizonte, V. 1, 2001. p. 308-315.

Transformações dos Processos Rítmicos de Offbeat Timing e Cross Rhythm em Dois Gêneros Musicais Tradicionais do Brasil. Revista Opus. Campinas: Anppom, No 11, Dezembro de 2005. Disponível em http://www.anppom.com.br/opus/opus11/sumario.htm Acesso em julho de 2008.

MELO, Zuza Homem de. A Era dos Festivais: uma parábola. São Paulo: Ed. 34, 2003.

MACHADO, Paulo Sérgio M. Edu Lobo. Revista da Nova História da Música Popular Brasileira. São Paulo: Abril Cultural, 2. ed., 1977.

MOLINA, Sidney. Música e Estética: Música Modal, Música Tonal, Música Atonal I. Revista Guitar Class, N. 7, p. 73, 2001.

MOURA, Fernando; VICENTE, Antônio. Jackson do Pandeiro: O Rei do Ritmo. São Paulo: Ed. 34, 2001.

NATTIEZ, Jean Jacques. O Combate entre Cronos e Orfeu - Ensaios de Semiologia Musical Aplicada.Trad. Luiz Paulo Sampaio. São Paulo: Via Lettera, 2005.

NEVES, José Maria. Música Contemporânea Brasileira. São Paulo: Ricordi Brasileira, 1981.

PARKS, Richard. S. The Music of Claude Debussy. New Haven and London: Yale University Press, 1989.

PAZ, Ermelina A. O Modalismo na Música Brasileira. Brasília: Ed. Unimed, 2002.

PEDRASSE, Carlos Eduardo. Banda de Pífanos de Caruaru: Uma Análise Musical. Dissertação de Mestrado. Campinas-Sp: Unicamp, 2002.

PEIXE, Guerra. Maracatus do Recife. São Paulo: Ricordi Brasileira, 1956. 
POWERS, Harold. Mode and Raga. The Music Quarterly, V.44, N. 4. Oct. 1958: 448-460.

PISTON, Walter. Harmony. New York : W.W.Norton \& Company, 5. ed., 1987.

RAMALHO, Elba Braga. Cantoria Nordestina: Música e Palavra. São Paulo: Terceira Margem, 2000.

RICCIARDI, Rubens. Jdanov, Brecht, Eisler e a Questão do Formalismo. Revista Música. São Paulo: V.8, N.1/2, p.169 - 206.

RIZEK, Ricardo. A Teoria da Harmonia em Platão: Um estudo sobre a identidade da núsica ocidental. Dissertação de Mestrado. ECA-USP, São Paulo, 2003.

RUE, Jan La. Guidelines For Style Analysis. New York-London: W.W.Norton \& Company, 1970.

SOARES, Astréia. Outras Conversas Sobre os Jeitos do Brasil: o nacionalismo na música popular. São Paulo: Annablume Fumec, 2002.

SCHOENBERG, Arnold. Harmonia, Trad. Marden Maluf. São Paulo: Editora Unesp, 1999.

Exercícios Preliminares em Contraponto. Trad. Eduardo Seincman: Via Lettere Editora e Livraria, 2001.

Funções Estruturais da Harmonia. Trad. Eduardo Seincman. São Paulo: Via Lettere Editora e Livraria Ltda, 2004.

RUSSELL, George. The Lydian Chromatic Concept of Tonal Organization for Improvisation. New York: Concept Publishing Company, 1959.

SQUEFF, Enio; WISNIK, José Miguel. O Nacional e o Popular na Cultura Brasileira. São Paulo: Brasiliense, 2004.

STURM, Fred. Changes Over Time: The Evolution of Jazz Arranging. Advance Music, 1996. 
The New Grove Dictionary of Jazz. New York and London: St. Martin's Press and The Macmillan Press Limited, 1996.

The New Grove Dictionary of Music and Musicians. London: Macmillian Publishers, 1980.

TINÉ, Paulo José de Siqueira. Três Compositores da Música Popular do Brasil: Pixinguinha, Garoto e Tom Jobim. Uma análise comparativa que abrange o período do Choro a Bossa Nova. Dissertação de Mestrado. ECA-USP, São Paulo, 2001.

TINHORÃO, José Ramos. Pequena História da Música Popular. São Paulo: Ed. do Círculo do Livro, s.d.

Cultura Popular Temas e Questões. São Paulo: Editora 34, 2001.

História Social da Música Popular Brasileira. São Paulo: Editora 34, 1998.

WRIGHT, Rayburn. Inside Score. New York: Kendor Mucis Inc., 1982.

ZAMACOIS, Joaquin. Armonia. Barcelona: Editora Labor, 14. ed., 1994.

\section{Discografia e Filmografia}

DAVIS, Miles. Kind of Blue. Columbia, 1959.

HANCOCK, Herbie. Mayden Voyage. Blue Note, 1964.

LOBO, Edu. Edu Lobo por Edu Lobo. Rio de Janeiro: Elenco, 1965.

LOBO, Edu. Vento Bravo. Direção de Regina Zappa e Beatriz Thielmann. (DVD) Biscoito Fino, 2007.

LOBO, Edu; Buarque, Chico. Dança da Meia Lua. Rio de Janeiro: Som Livre, 1985. 
NASCIMENTO, Milton. Milton Nascimento. Rio de Janeiro: Philips, 1967.

NASCIMENTO, Milton. Courage. A \& M, 1968.

POWELL, Baden; Moraes, Vinicius. Afro-sambas. Rio de Janeiro: Elenco, 1966.

POWELL, Baden. Baden à Vontade. Rio de Janeiro: Elenco, 1962.

SANTOS, Moacir. Coisas. Rio de Janeiro: Forma, 1965.

A Arte da Cantoria: Cangaço. São Paulo: Instituto Itaú Cultural, s/d.

A Arte da Cantoria: Ciclo do Padre Cícero. São Paulo: Instituto Itaú Cultural, s/d.

Candomblé da Bahia: Nação Ketu com Luiz Muriçoca. Continental, LP 1-04-405-332, 1963.

Capoeira Cordão de Ouro: Mestre Suassuna e Dirceu. Continental, 1975.

Capoeira, Samba, Candomblé. Berlim: Museum Collection Berlin, 1990.

Cocos: Alegria e Devoção. [CD do livro homônimo] João Pessoa: Editora Universitária da UFRN, 2000.

Documento Sonoro do Folclore Brasileiro, V. 5. Berimbau e Capoeira/BA. São Paulo: Instituto Itaú Cultural, s/d.

Maracatu Leão Coroado: 140 Anos. Recife: Fundacultura Pernambuco, 2005.

Missão de Pesquisas Folclóricas: Música Tradicional do Nordeste 1938. São Paulo: SescPrefeitura da Cidade de São Paulo-Centro Cultural São Paulo, 2006.

Responde a Roda Outra Vez: Música Tradicional de Pernambuco e Paraíba no Trajeto da Missão de 1938. Realização FadeUFPE, Departamento de Música - Núcleo de 
Etnomusicologia UFPE, Laboratório de estudos da Oralidade UFPA e As. Respeita Januário, 2005.

\section{Partituras}

DVORAK, Antonin. Quartet, Op.96, F major. London: Ernest Eulenburg, s.d.

GRIEG, Edvard. Sonata, Op.45, C menor. New York: G. Schirmer, 1938.

GISMONTI, Egberto. Egberto Gismonti. Genève-Switzerland: Mondiamusic, 1990.

CHEDIAK, Almir (org.). Songbook da Bossa Nova. - V. I, II e III. Rio de Janeiro, Ed. Lumiar, 1989.

(org.). Songbook Edu Lobo. Rio de Janeiro: Ed. Lumiar, 1994.

MUSSORGSKY, Petrovich. Quadros de Uma Exposicion. Buenos Aires: Ricordi Americana, 1948.

PASCOAL, Hermeto. Calendário do Som. São Paulo: Ed. Senac Instituto Cultural Itaú, 2000.

Songbook de Frevos. Recife: Prefeitura da Cidade do Recife, 2003. 
Anexos

Análise de trechos de três peças Nacionalistas do Romantismo

E três improvisos jazzísticos

\section{Quarteto Americano}

A. Dvorak
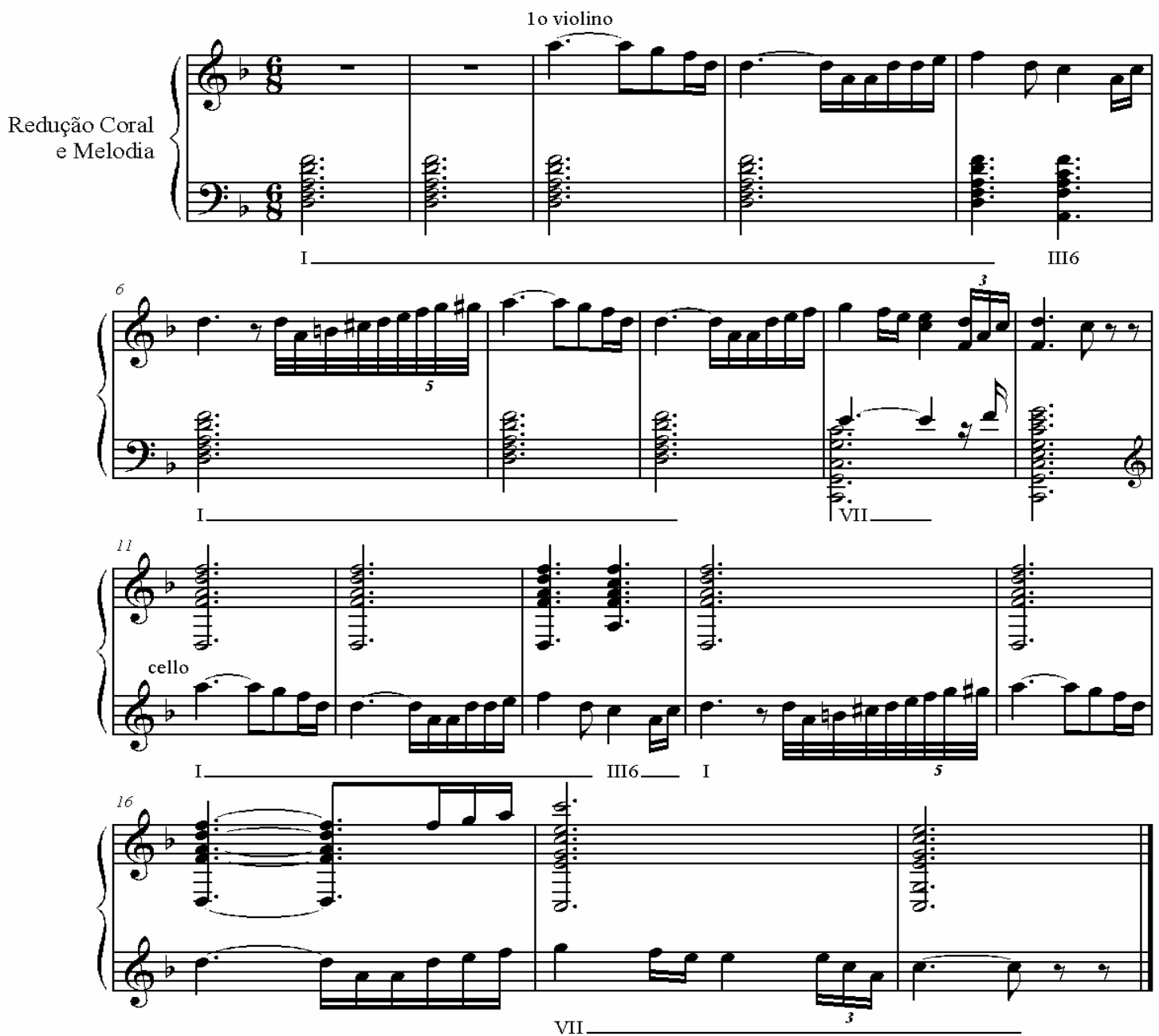


\section{Sonata III (3o Mov.)}

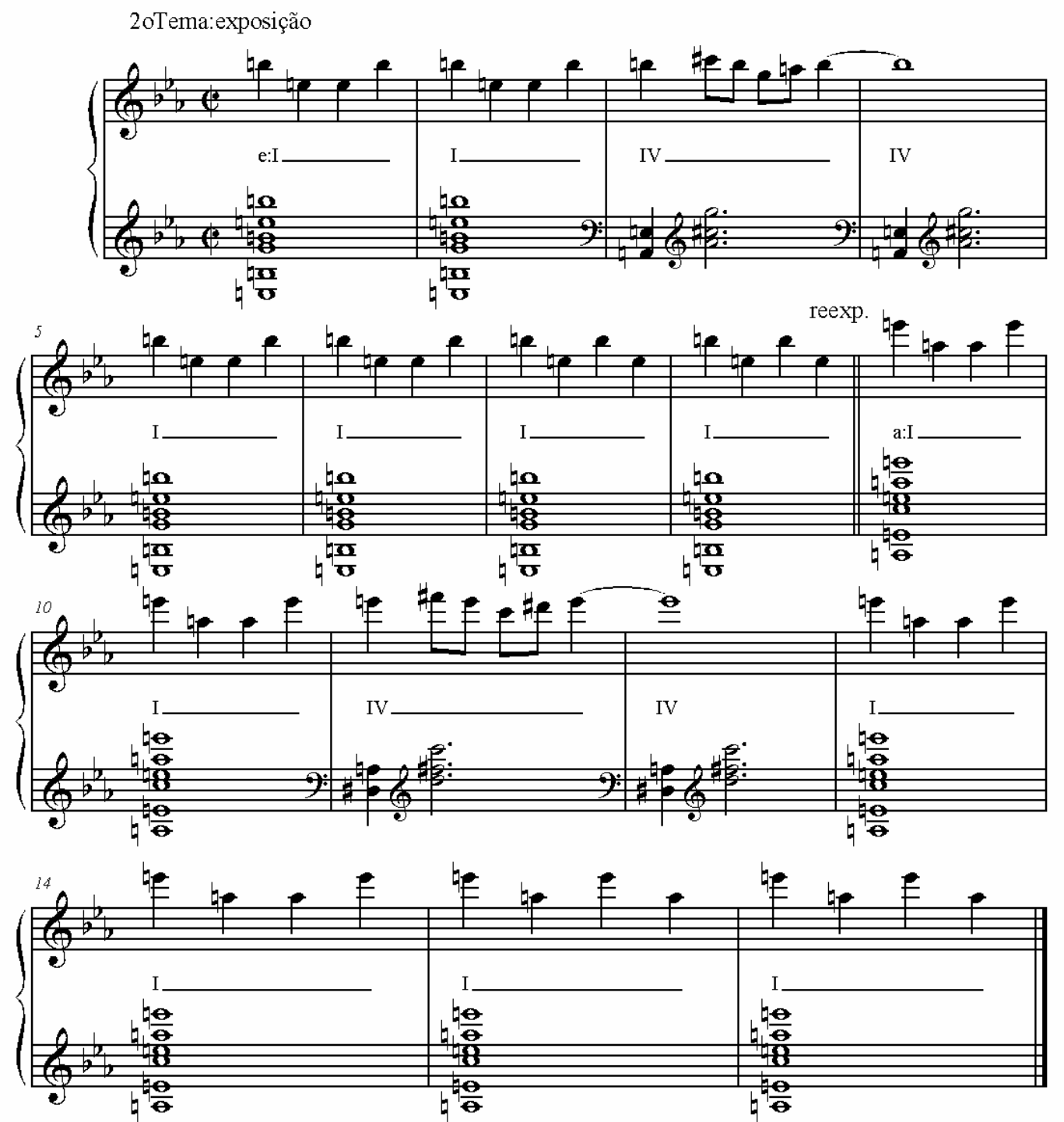




\section{La Gran Puerta de Kiev}

\section{P. Mussorgsky}
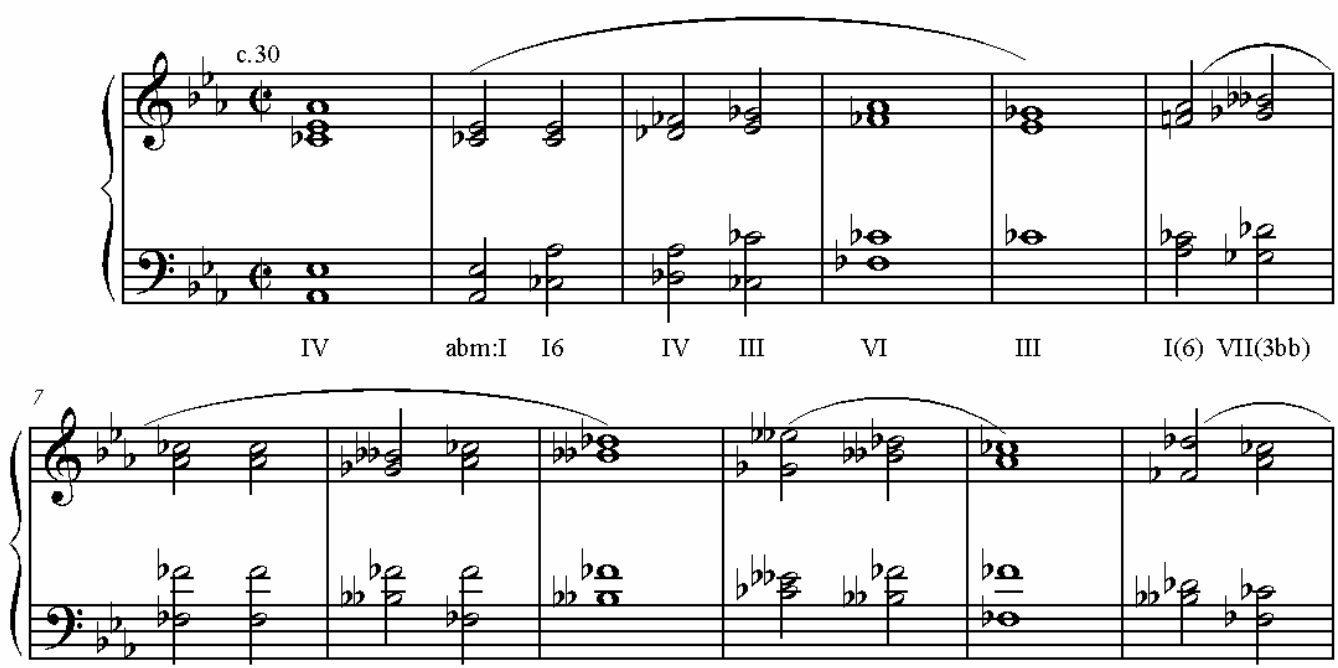

$\begin{array}{lllllllll}\text { VI } & \text { VIIb } & \text { VI } & \text { IIb } & \text { III }(3 \mathrm{bb}) & \text { IIb } & \text { VI } & \text { IIb } & \text { VI }\end{array}$

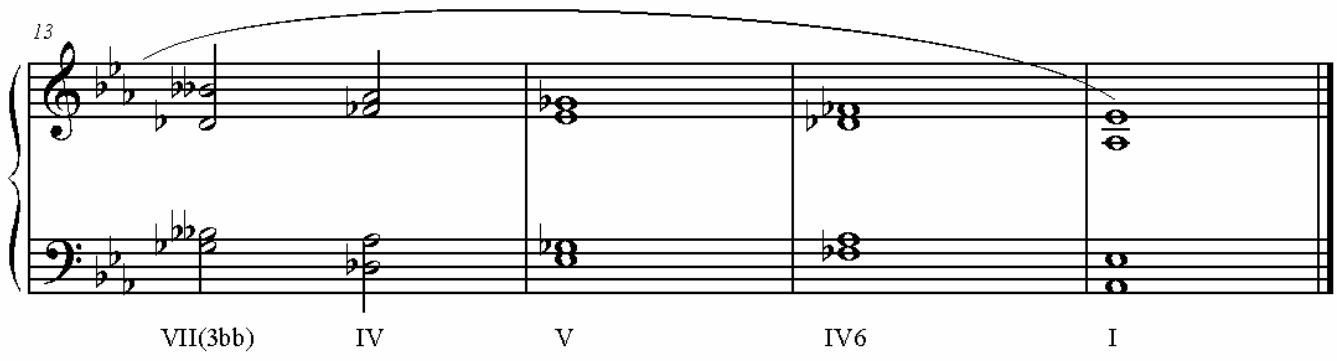




\section{So What}

Redução analisada a partir da transcrição do improviso de Miles Davis (10 chorus)

As frases estão separadas e o ritmo retirado; a letra $a$ indica antecipação; arp. indica arpejo; esc. movimento escalar, + ou cr. Aproximação cromática; b bordadura e os números o intervalo da primeira última nota da frase em relação ao acorde. É importante salientar que, em relação ao arpejo, uma cifra é indicada quando ele não corresponder ao acorde do momento, ou seja, quando o improvisador sobrepuser ao acorde original um outro, normalmente com a intenção de se obter extensões dos acordes básicos.
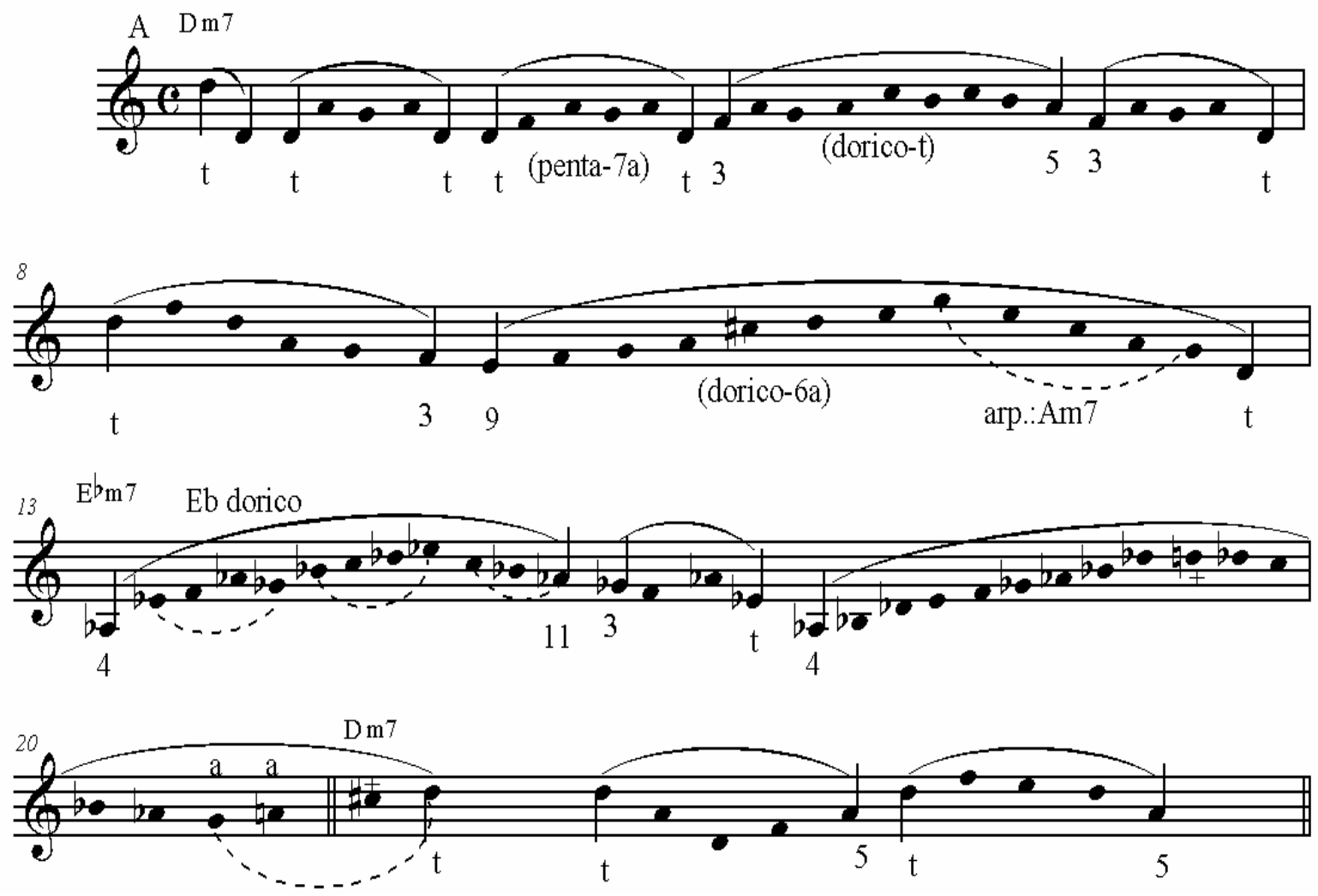


\section{Maiden Voyage (H. Hancock)}

Redução analisada a partir da transcrição do improviso de George Colemann Dsus7(9)

Fsus7(9)

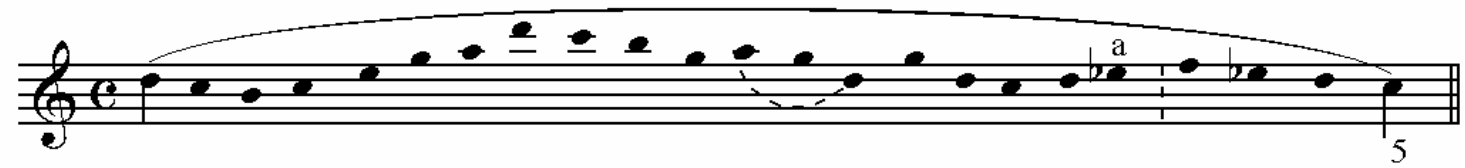

Dsus7(9)
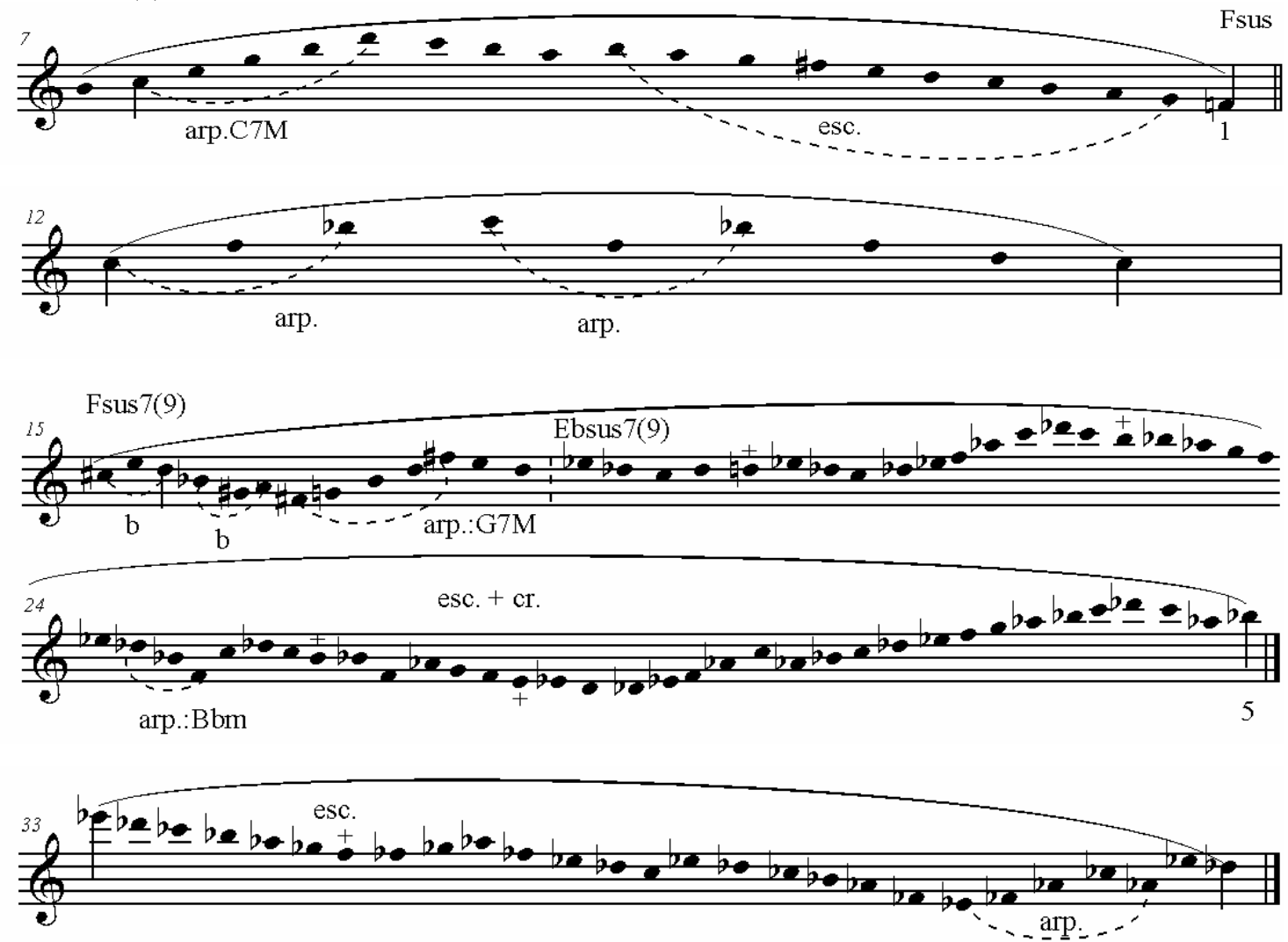

Dsus7(9)
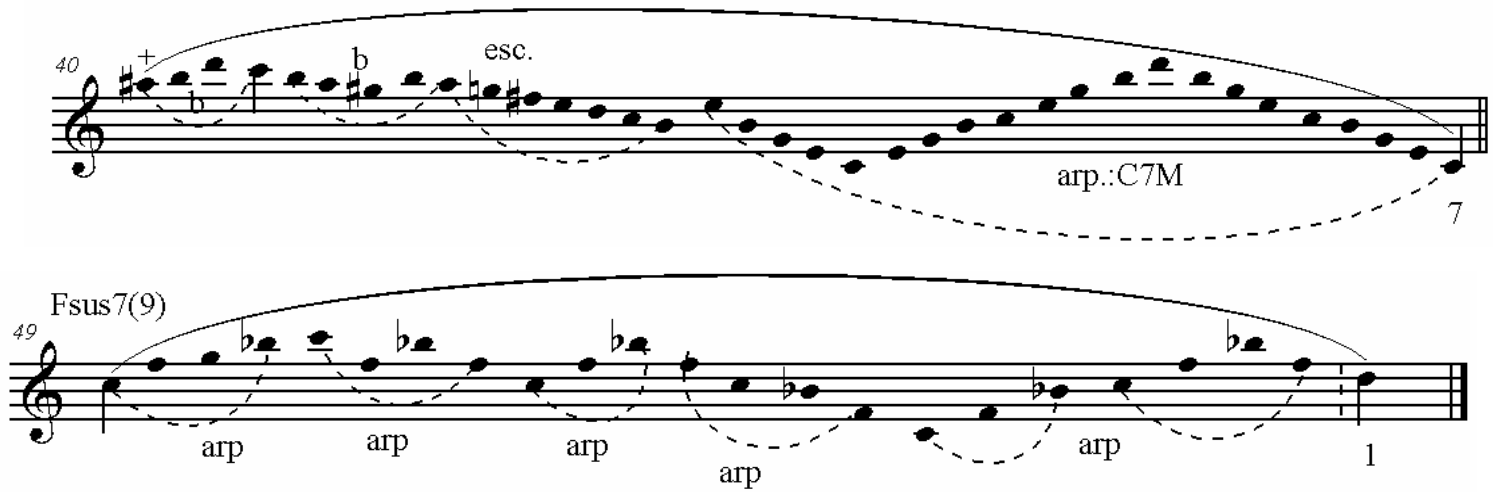
Time Remembered:

Redução analisada a partir da transcrição do improviso de Bill Evans ( $3^{\circ}$ chorus $)^{157}$
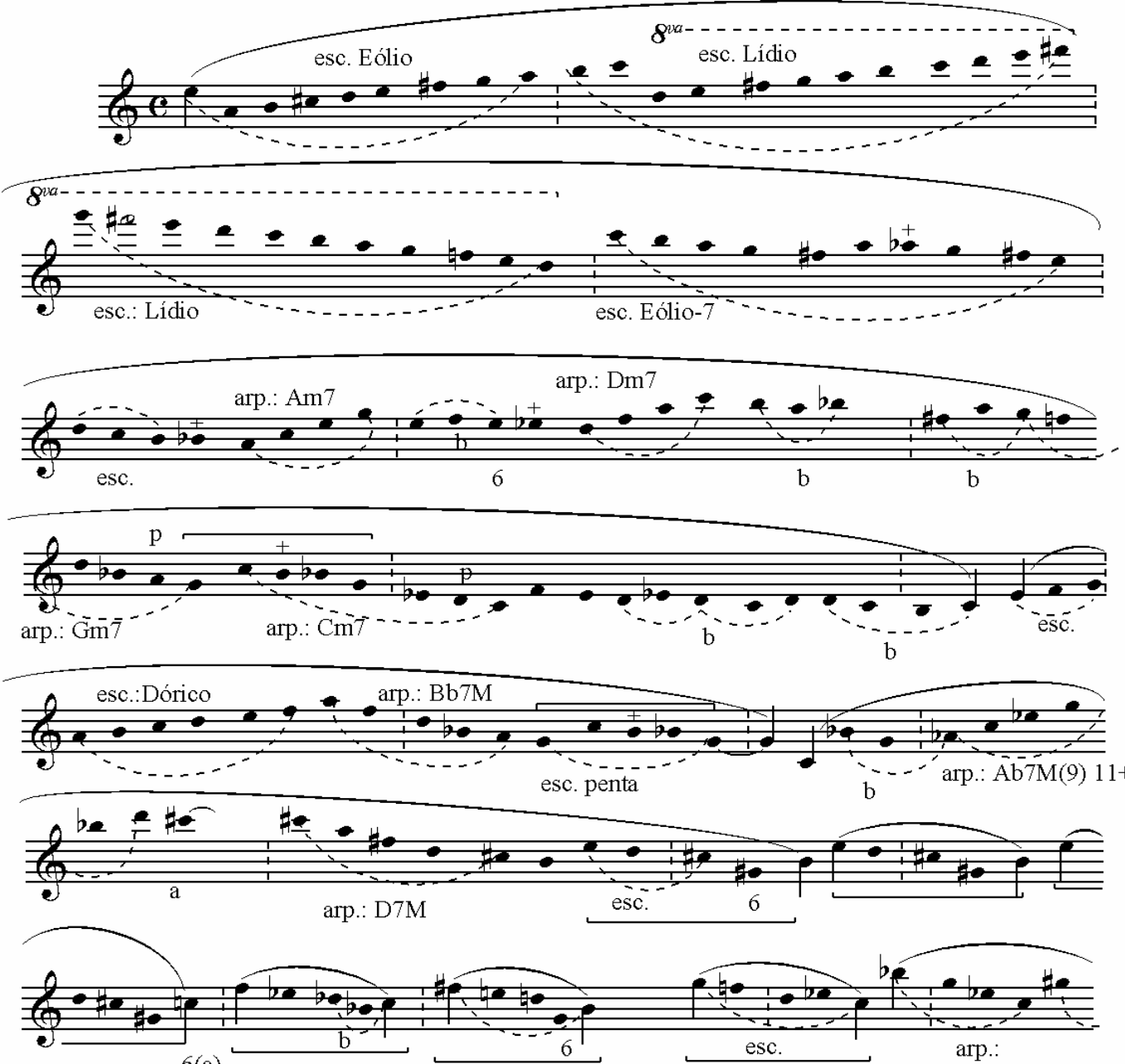

6 (a)
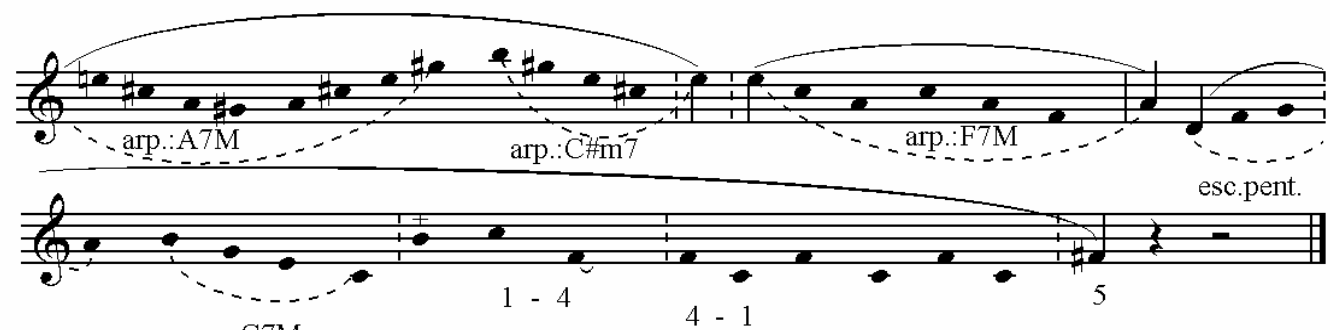

arp.:C7M

${ }^{157}$ Análise realizada a parir da transcrição de Jed Distler em Evans, Bill. Since We Met. Fantasy OJCCD 622-2. Gravado ao vivo no Village Vanguard em 1974. 